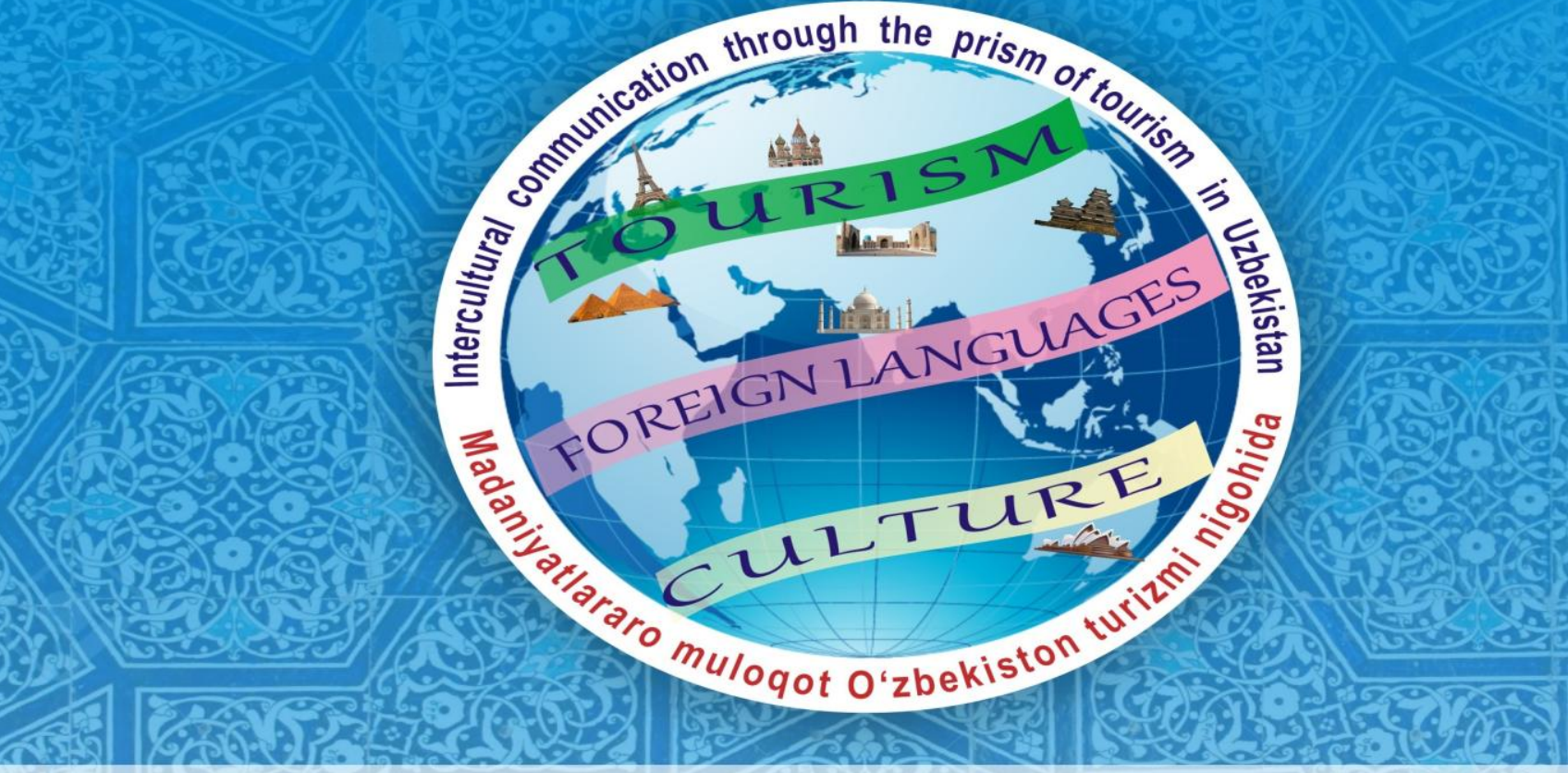

INTERCULTURAL COMMUNICATION THROUGH THE PRISM OF TOURISM IN UZBEKISTAN: EXPERIENCE, CURRENT ISSUES AND PERSPECTIVES MADANIYATLARARO MULOQOT O'ZBEKISTON TURIZMI NIGOHIDA: TAJRIBA, DOLZARB MUAMMOLAR VA ISTIQBOLLAR

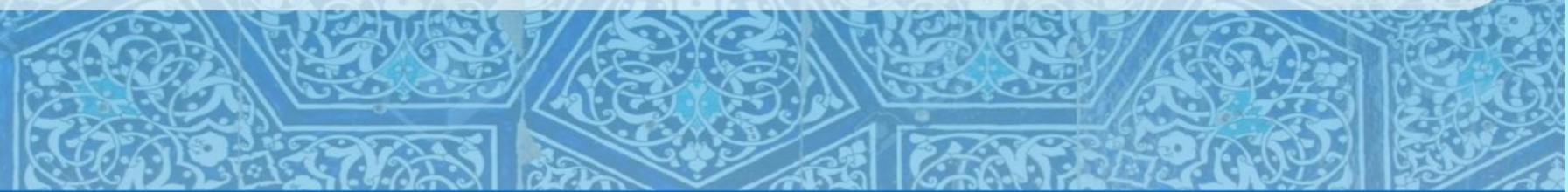

XALQARO ILIMIY-AIVIALIY ANJUIMIAN

MATERIALLARI
PROCEEDINGS

OF INTERNATIONAL SCIENTIFIC-PRACTICAL CONFERENCE

\title{
1- ҚИСМ
}
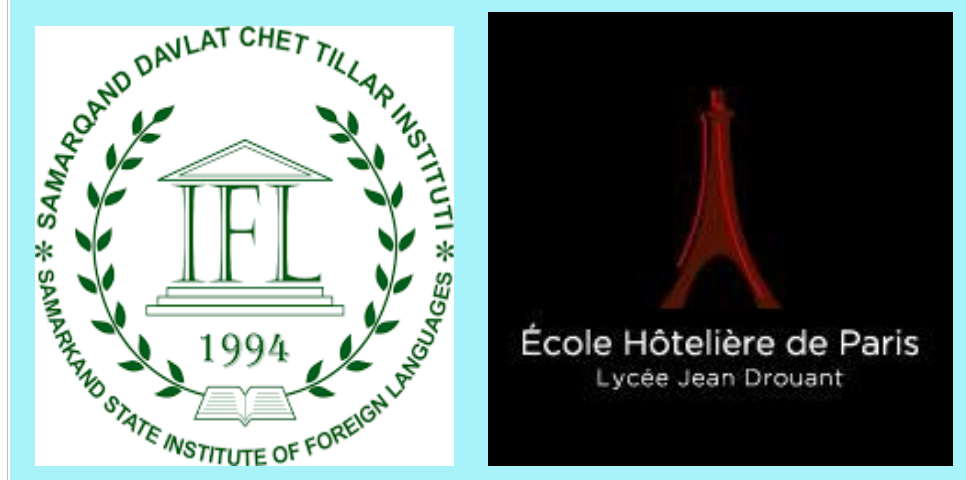

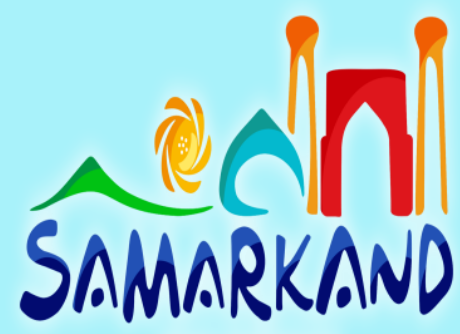

ENJOY HOSPITALITY 


\author{
ЎЗБЕКИСТОН РЕСПУБЛИКАСИ \\ ОЛИЙ ВА ЎРТА МАХСУС ТАЪЛИМ ВАЗИРЛИГИ
}

САМАРҚАНД ДАВЛАТ ЧЕТ ТИЛЛАР ИНСТИТУТИ

МАДАНИЯТЛАРАРО МУЛОҚОТ ЎЗБЕКИСТОН

ТУРИЗМИ НИГОХИДА: ТАЖРИБА, ДОЛЗАРБ

МУАММОЛАР ВА ИСТИҚБОЛЛАР

\title{
INTERCULTURAL COMMUNICATION THROUGH THE PRISM OF TOURISM IN UZBEKISTAN: EXPERIENCE, CURRENT ISSUES AND PERSPECTIVES
}

Халқаро илмий-амалий анжумани

МАТЕРИАЛЛАРИ

PROCEEDINGS

of international scientific-practical conference

$$
\text { 1- ҚИСМ 1- PART }
$$

Самарқанд шахри, 2020 йил, 29-30 июнь

Samarkand city, June 29-30, 2020

Самарқанд - 2020

Samarkand - 2020 


\section{УўК 4}

\section{ББК 81.2-5}

M 13

Маданиятлараро мулоқот Ўзбекистон туризми нигохида: тажриба, долзарб муаммолар ва истиқболлар. Халқаро илмий-амалий анжуман материаллари. Самарқанд: СамДЧТИ, 2019. - 366 бет.

Мазкур халқаро илмий-амалий конференция материалларидан иборат тўпламга хорижий тиллар - маданий меросни талқин қилиш асоси сифатида, мулоқот жараёнида лингвомаданий хусусиятларнинг воқеланиши, туризм сохаси вакилларининг лингвистик ва ижтимоий-маданий салохиятини ривожлантириш асослари, Ўзбекистонда туризмни ривожлантиришнинг истиқболлари, маданиятлараро мулоқот хорижий тил таълимининг етакчи омили сифатида каби масалаларга оид мақолалар киритилган. Конференция туризм, хорижий тил ва маданият сингари уч хил бошқабошқа сохаларнинг ижтимоий-иқтисодий, маданий ва таълим каби долзарб йўналишларда бир-бири билан ўзаро уйғунлашган холда акс этишини ўз ичига олади. Ушбу сохалар бўйича анча тажрибага эга хамда илмий нашрлари билан илм ахли назарига тушган устоз-олимлар: филологлар, тарихчилар, маданиятшунослар, педагоглар ва гид-таржимонлар билан бир қаторда, шу жабхаларда илмий кузатишларини эндигина бошлаган тадқиқотчилар, магистрантларнинг хам изланиш натижалари мазкур тўпламдан ўрин олди. Тўплам маданиятлараро мулоқот, туризм, тарих, маданият, хорижий тиллар каби масалалар билан қизиқувчи кенг китобхонлар оммасига мўлжалланган.

The conference is scheduled for the plenary session and the following sections: foreign languages as a basis for the interpretation of cultural heritage, focus on linguo-cultural features in the process of communication, development of linguistic and socio-cultural skills of tourism professionals, prospects for the development of tourism in Uzbekistan, intercultural communication as one of the main directions in the study of a foreign language. The collection includes scientists' articles who has a great amount of experience in the field of linguistics, history, culture, pedagogy and guide translator, besides that the collection includes young researchers' and master students' articles. The collection is designed for the researchers who are interested in the issue of intercultural communication, tourism, history, culture and foreign languages.

\section{Тахрир хайъати / Editorial board}

п.ф.д. И.М.Тухтасинов (раис) Tukhtasinov I.M. (chairman)

доч. Ш.С. Ашуров (раис ўринбосари) Ashurov Sh.S (vice-chairman)

проф. Ш.С. Сафаров Safarov Sh.S.

доц. С.И. Исмоилов Ismoilov S.I.

ф.ф.н. Д.А. Киселев Kiselyov D.A.

ф.ф.н. Н.Н. Сувонова (масъул мухаррир) Suvonova N.N. (chief editor)

к.ўқ. Р.А. Шукурова (масъул котиб) Shukurova R.A. (executive secretary)

\section{Тўпламдан ўрин олган мақолаларнинг савияси, сифати ва илмий далилларнинг хаққонийлиги хамда мазмуни учун муаллифлар масъулдирлар.}




\section{ТУХТАСИНОВ ИЛХОМЖОН \\ МАДАМИНОВИЧ}

Педагогика фанлари доктори, профессор, Самарқанд давлат чет тиллар институти ректори

\begin{tabular}{llllr}
\multicolumn{2}{c}{ Респубикамизда } & \multicolumn{2}{c}{ туризмни } & \multicolumn{2}{c}{ ривожлантириш } \\
жараёнида & замонавий гид & таржимонларни & тайёрлаш \\
масалалари & хорижий тил & мутахассисларини & тайёрлаб \\
чиқарувчи & олий & таълим & муассасалари & олдига \\
масъулиятли & бир вазифани юклайди.
\end{tabular}

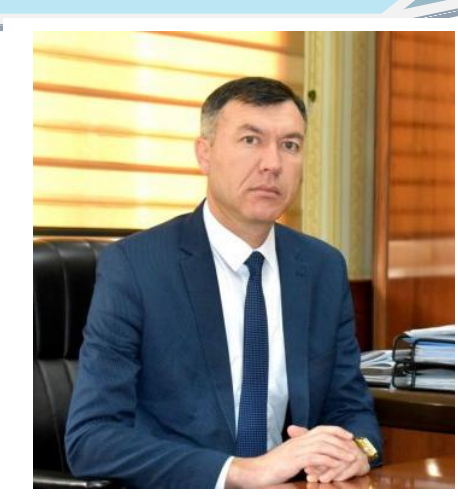

Туризм сохасида хорижий тилларни мукаммал ўзлаштирган, салохиятли хамда замон талабларига мос лингвистик ва маданий компетенцияларга эга малакали гидтаржимонлар фаолияти мухим ўрин эгаллайди. Туризм сохасида кадрлар тайёрлаш ва уларни қайта тайёрлаш, шунингдек, уларнинг малакасини ошириш, шу жумладан соқавий хорижий ўқув марказларида ва таълим муассасаларида стажировкалардан ўтиш масалаларига алохида эътибор қаратиш лозим. Ўзбекистоннинг туризм салохиятини чет эл туризм бозорларида тарғибот қилишда албатта, малакали хорижий тил мутахассислари асқотади.

Туризм маданиятлараро мулоқот ва тарихий алмашинувни самарали йўлга қўйишда мухим омил бўлиб хизмат қилади. Шундай экан, "Маданиятлараро мулоқот Ўзбекистон туризми нигохида : тажриба, долзарб муаммолар ва истиқболлар" мавзусидаги мазкур халқаро илмий-амалий анжуманнинг ташкил этилиши хам айни муддао. Ушбу анжуман Ўзбекистонда туризм сохасини янада ривожлантириш бўйича ижтимоий ахамиятга эга масалаларни ижобий хал этишнинг назарий жихатларини кўрсатиб бериши шубхасиздир.

Шу ўринда мазкур халқаро анжуманни хар йили анъанавий тарзда ташкил этган Француз тили ва адабиёти кафедраси жамоасига ўз миннатдорчилигимни билдираман. Конференция ишига омад тилайман.

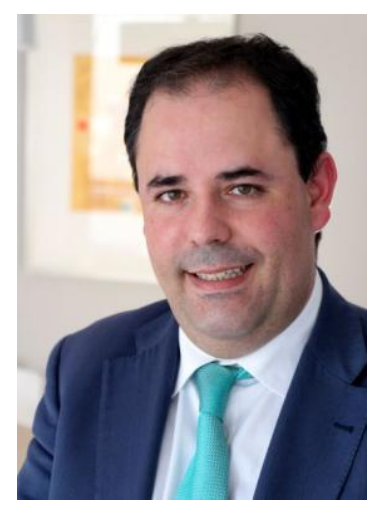

\section{CARLOS URIARTE SANCHEZ \\ Profesor de Derecho de la Universidad Rey Juan Carlos Madrid, España}

Uzbekistan has the necessary conditions for the tourism industry to be one of the fundamental sectors in the country's development from an economic and social point of view. For this, it is important that Uzbekistan learn from the practice of the other tourist countries in the world. Its historical monuments, its rich history, its landscapes, its people, make this sector have even more potential and be an element of development, cohesion and sustainability of the entire country. It is important that Uzbekistan equips itself with the most advanced legislation in the world in the tourist sector and in the rights of consumers. Only though the implementation of trust and security for tourists the sector will be able to enjoy e sustainable future.

\section{ALEJANDRO PASTRANA}

President of the company "Gedepsa"

It is clear that tourism is a sector that will continues to increase, for the same reason that in developed societies people is producing more in less time, so these persons need to use this free time and, one way is the tourism.Therefore, tourism is a sector with a good present and an excellent future and at the same time a job creator.

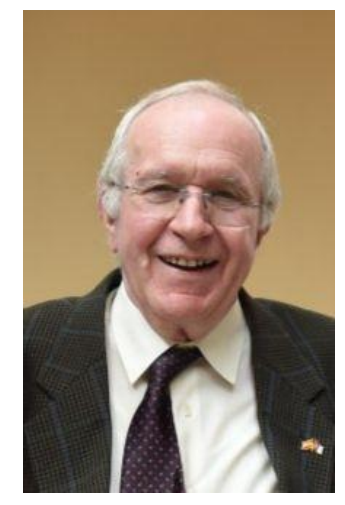




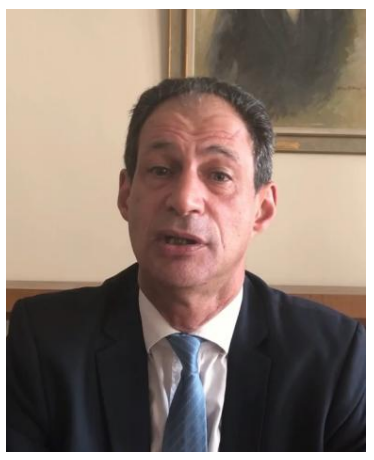

MICHEL HARTBROT

\section{Enseignant en charge des relations internationales École Hôtelière de Paris Lycée Jean Drouant}

La pandémie du coronavirus qui a atteint aujourd'hui pratiquement tous les pays du monde et les mésures épidémiologies et sanitaires qui ont été imposées ont profondement touché plusieurs secteurs de l'économie. Dans ce contexte, le secteur touristique s'est révélé particulièrement vulnérable. Cette situation peut être considérée comme impasse sans issu, or elle peut devenir une nouvelle piste de réflexion et, surtout, d'action. Actuellement, les professionnels du tourisme et des domaines contigus ne doivent pas demeurer en état d'attente, mais agir, communiquer et collaborer. Je suis certain que le colloque scientifique et pratique intitulé "Communication interculturelle à travers le tourisme en Ouzbékistan: expérience, tâches d'actualité et perspectives" organisé par l'Institut des langues étrangères de Samarkand servire de plateforme de communication et d'échanges des professionnels qui permettra de répondre aux questions et de trouver des sollutions efficaces.

Veuillez agréer, chers organisateurs et participants du colloque, nos sincères salutations et souhaits du travail efficace!

\section{MIRIAM FOPIANI ROMAN}

Professeure d'Espagnol et de Français Institut des Langues Étrangères de Samarcande

La conférence internationale organisée au sein de l'Institut nationale des langues étrangères de Samarcande par la chaire de la langue et la littérature française sur le thème "Communication interculturelle à travers le tourisme en Ouzbékistan: Expérience, enjeux et perspectives attirera I attention au pubıque concerne.

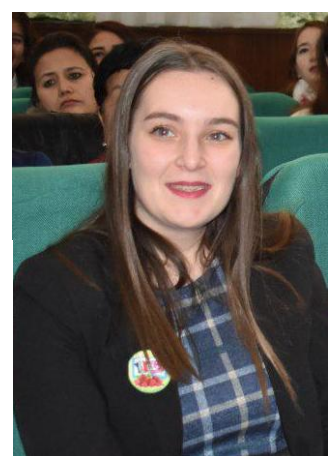

Cet événement scientifique est initié afin de contribuer au développement de l'industrie du tourisme en tant que plate-forme de communication interculturelle et de renforcer les compétences linguistiques et culturelles des professionnels du tourisme.

La conférence offre l'occasion de présenter au monde le riche patrimoine historique et culturel de l'Ouzbékistan, d'échanger les expériences et les opinions sur le dialogue interculturel et de contribuer à l'amélioration des compétences linguistiques et socioculturelles des professionnels du tourisme.

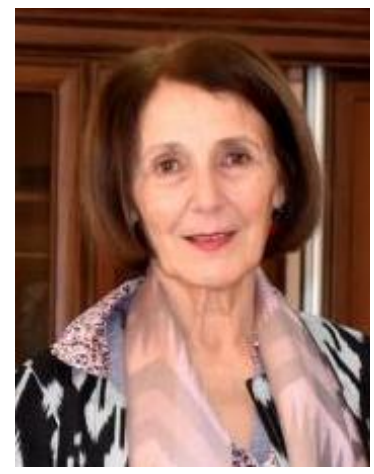

\section{GENEVIEVE MESSAINGUIRAL \\ Professeur certifiée de Mathématiques. Enseignante Français Langue Etrangère}

Un touriste qui connaît au moins un peu l'histoire de l'humanité n'a pas à se poser de questions: qu'est-ce qui rend le tourisme en Ouzbékistan si attrayant et ce qui le distingue de centaines d'autres destinations touristiques. Bien sûr, le tourisme en Ouzbékistan est traditionnellement associé aux villes du patrimoine mondial de l'UNESCO - Samarkand, Boukhara et Khiva.

Leur histoire remonte à des siècles, les anciens murs de remparts rappellent les phalanges d'Alexandre le Grand, les hordes de Gengis Khan et les formations de bataille des guerriers de Tamerlan.Dans le même temps, tout au long de voyage en Ouzbékistan, vous aurez l'occasion de ressentir l'hospitalité et la gentillesse des habitants de l'Ouzbékistan, qui ont la cordialité et le respect des invités.À propos des fruits et légumes naturels les plus délicieux et les plus sucrés de l'Univers, pour lesquels l'Ouzbékistan est si célèbre, je garderai dans mon mémoire.En plus des principales villes touristiques, il existe de nombreux endroits uniques et intéressants, dont la visite peut être un excellent ajout aux principaux domaines du tourisme en Ouzbékistan. 


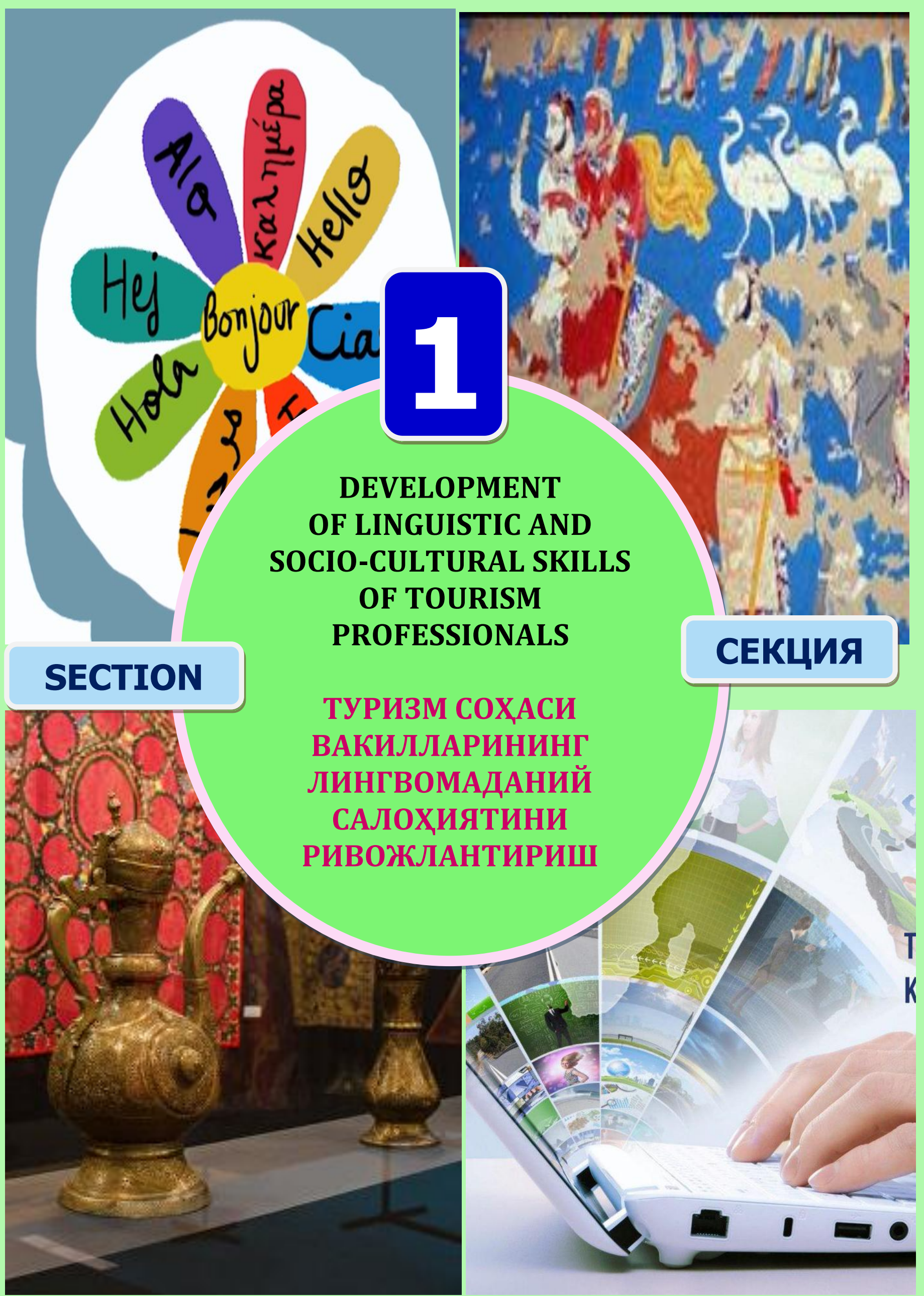




\section{PARTICIPANTS :}

1. Тўхтасинов Илхомжон Мадаминович педагогика фанлари доктори, доцент СамДЧТИ ректори

2. Emmanuel Egbeiyon Ph.D. University of Benin Edo state, Nigeria

3. Kamal bin Al Khassan Ph.D. Assistant Professor and Extension Specialist, University of the USA in Dubai

4. Najd Hassan Raffi Ph.D. Associate Professor, Saudi Arabia Jeddah ,Richmond University London

5. Michel HARTBROT Enseignant en charge des relations internationales École Hôtelière de Paris Lycée Jean Drouant

6. Alejandro Pastrana President of the company "Gedepsa"

7. Нурали Нурзод к.ф.н., заместитель директора Научно-исследовательск. института гуманитарных наук ГОУ «ХГУ имени академика Б. Гафурова»

8. Эркаев Сафбар Абдулхайрович доцент, кандидат исторических наук, ХГУ имени акад. Б.Гафурова

9. Искандарова Мадина Набиевна Доц. ХГУ имени акад. Б.Гафурова

10. Джабборова Курбоной доцент, ХГУ имени акад.Б.Гафуррова

\section{ИШТИРОКЧИЛАР:}

11. Хошимов Фируз Джаббарович Преп. Института Экономики и Торговли ТГУК в г. Худжанде

12. Djurakulov Jamshid Avazovich Samarqand davlat muzey-qo'riqxonasi Turizm va marketing bo'limi boshlig'i

13. Normetova Odila Ruzmatovna Xorazm viloyati, Shovot tumani, 14 -maktab o'qituvchisi

14. Sulaymanova Gulnaz Janabaevna 46 IDUM Progress Teacher Nukus city, Republic of Karakalp.

15. Суюнов Шерзод Самарқанд давлат чет тиллар институти ўқитувчиси

16. Тошпулатов Д.А. ТАТУ Самарқанд филиали ўқитувчиси

17. Хамдамов Ислом Акрамович Самарқанд давлат чет тиллар институти ўқитувчиси

18. Шамсиева Шохистахон Кудратуллаевна Шарқшунослик университети ўқитувчиси

19. Rakhimova Sadokat Makhmudovna Urgench state University Tourism and economy faculty, PhD student

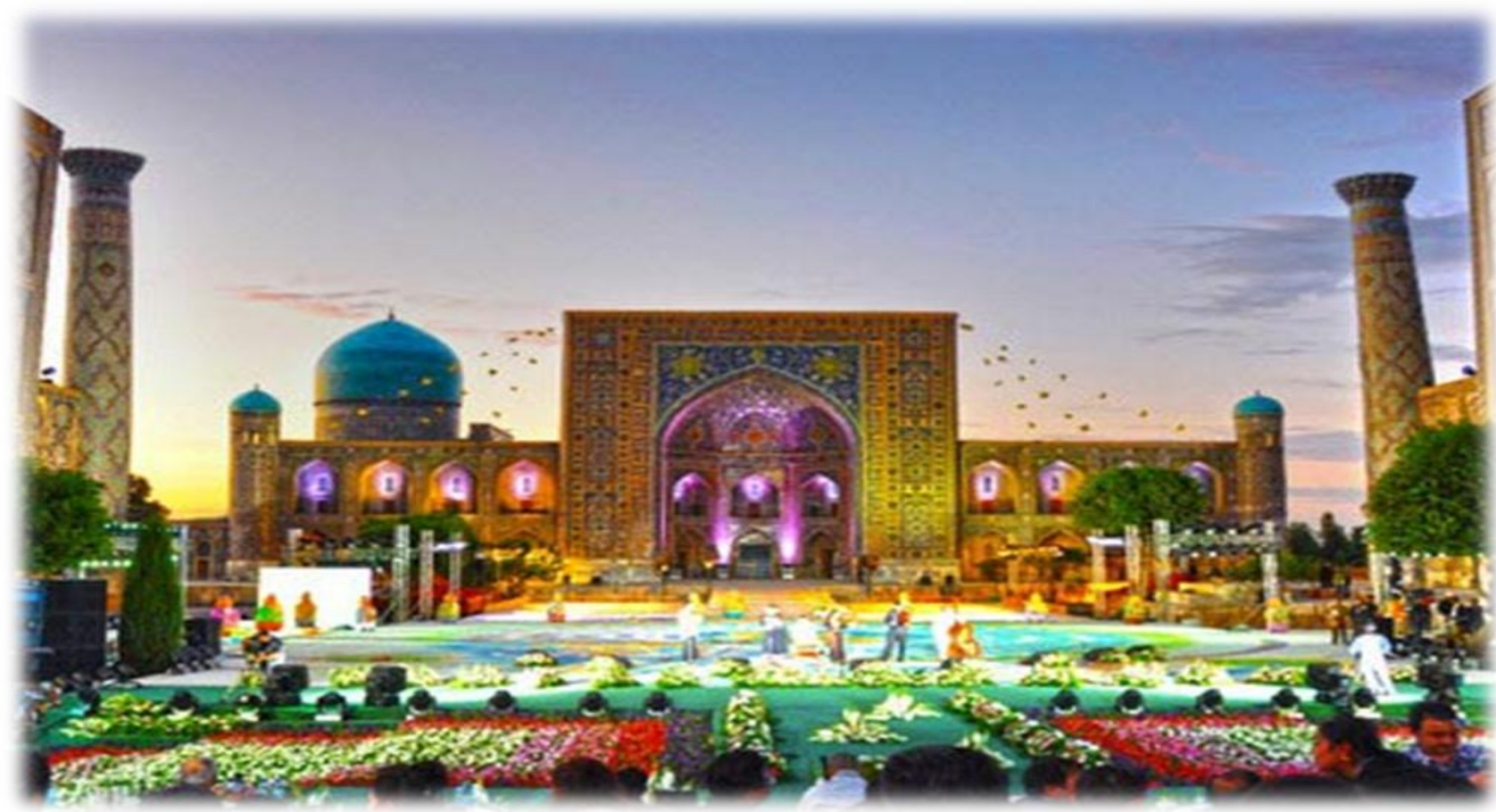




\section{ГИД-ТАРЖИМОН ТАЙЁРЛАШДА НУТҚ МАДАНИЯТИНИНГ ЎРНИ}

\section{Тўхтасинов Илхомжон Мадаминович \\ Самарқанда давлат чет тиллари институти ректори, педагогика фанлари доктори, доцент. E-mail: ilhom tuhtasinov@mail.ru}

Бугунги кунда кўплаб ривожланган давлатлар қатори Ўзбекистонда хам туризм сохасини ривожлантириш борасида хукуматимиз томонидан бир қатор ислохатлар амалга оширилмоқда. Бу ислохатларнинг бош омили сифатида Ўзбекистон Республикаси Президентининг «Ўзбекистон Республикаси туризм салохиятини ривожлантириш учун қулай шарт-шароитлар яратиш бўйича қўшимча ташкилий чоратадбирлар тўғрисида»ги 2018 йил 3 февралдаги ПФ-5326-сон Фармони, "Ўзбекистон Республикасида туризмни жадал ривожлантиришга оид қўшимча чора-тадбирлар тўғрисида" ги 2019 йил 5 январдаги ПФ-5611-сон Фармонларини кўришимиз мумкин.

Мамлакатда туризм салохиятини ошириш, Ўзбекистонга чет эллик туристлар ташрифини янада кўпайтиришда юқори малакали гид-таржимонларнинг роли каттадир. Хорижлик мехмонларга юқори сифатли хизмат кўрсатишда гидтаржимонларнинг ўз касбига профессионал ёндашуви юртимизнинг туризм бўйича хизмат кўрсатиш сохасига хорижлик мехмонлар томонидан берилган бахо хисобланади. Профессоинлар гид-таржимонларни тайёрлашда талабаларнинг нафақат ўз сохалари бўйича билим ва кўникмаларига, шунингдек уларнинг нутқ маданиятига, этикасига хам катта ахамият бериш кераклиги мухим масалалардан хисобланади.

Мазкур рисоламизда гид-таржимонлар учун мухим касбий талаблардан бири бўлган нутқ маданиятининг умумий хоссалари ва асосий талаблари хақида сўз юритамиз.

Нутқ маданияти фани тилшуносликнинг ўзига хос амалий сохасидир. У тилшуносликнинг назарий курсларидан олинган билимларга суянган холда тўғри ва чиройли нутқ тузиш йўлларини ўргатади $[3,36]$. У тил, тил нормалари, нутқ, нутқнинг сифатлари, нутқий услублар, нутқда учраши мумкин бўлган камчилик ва хатолар, нутқнинг талаффузига доир муаммолар юзасидан бахс юритади. Нутқ маданияти фан сифатида ўз текшириш объекти ва вазифаларига эга. Унинг текшириш предмети нутқнинг тил қурилиши, адабий тил нормалари ва нутқнинг коммуникатив фазилатларидир. Нутқ маданияти назариясида тил нормаси марказий тушунчадир. Тил маданиятининг асосий ўрганиш обекти адабий тил нормалари, асосий вазифаси эса ушбу нормадаги иккиланишларни бартараф этишдир.

Академик А.Хожиев ўзининг «Лингвистик терминларнинг изохли луғати»асарида нутқ маданияти терминига қуйидагича таъриф беради:

1. Филология фанининг жамият тараққиётидаги тилдан фойдаланиш жараёнини ўрганиш, кишилар орасидаги алоқа воситаси бўлган тилдан фойдаланиш қоидаларини илмий асосда белгилаш билан шуғулланувчи бўлими;

2. Нутқнинг нормативлиги, унинг маълум тарихий тараққиёт даврида шу тилда сўзлашувчи жамоа томонидан қўйиладиган талабларга мослиги: талаффуз, урғу,сўз қўллаш, шакл ясалиши, сўз бирикмаси ва гап тузиш меёрларига амал қилиш. Нутқнинг нормативлиги фикрнинг аниқ, равшан ва софлигини хам ўз ичига олади $[4,62]$. Демак, нутқ маданияти тушунчаси икки хил (тор ва кенг) маънода қўлланилар экан.

Нутқ маданияти фани тилнинг хамма сохалари бўйича адабий тил нормаларини тадқиқ қилиб боради. Энг мақбул ходисаларнинг адабий нормасини мустахкамлаш учун тавсиялар беради. Бироқ бу фан адабий нормаларни яратмайди, баъзи бир ходисаларни 
норма сифатида мажбуран киритмайди. Балки хар бир миллатнинг миллий адабий тили фаолияти, унинг ривожланишини кузатиб боради, объектив қонунларни кашф этади, шулар асосида таълим беради.

Нутқ маданияти тилшуносликнинг назарий билимларига суянган холда тўғри ва чиройли нутқ тузиш санатини ўргатади. У тарбияшуносликнинг малум сохаси сифатида чиройли нутқ сифатлари, нутқ услублари, камчилик ва хатолари, нутқий асослари, кўринишлари хамда талаффузга доир муаммолари юзасидан билим беради. Кишиларда маданий нутқ малакасини шакллантириш, яни адабий тил, умумтил мезонларига, мавжуд қоидаларга тўла амал қилган холда нутқ тузиш малакасини шакллантириш нутқ санъатининг асосий вазифаларидир $[2,100]$. Шу билан бирга яхши нутқни бахолаш ва тарғиб қилиш хам унинг вазифаси доирасига киради.

Нутқ хар томонлама яхши бўлишиучун ўз олдига маълум талабларни қўяди. Бу талаблар нутқнинг асосий сифатлари,хусусиятлари деб юритилади [1, 76]. Улар нутқнинг тўғрилиги, аниқлиги, мантиқийлиги,таъсирчанлиги, тозалиги, тушунарлилиги ва мақсадга мувофиқлигидир.

1. Нутқнинг тўғрилиги. Нутқ маданиятининг зарур ва биринчи шарти сифатида адабий тилнинг маълум пайтда қабул қилинган нормасига қатъий ва аниқ мувофиқ қилиниши, унинг талаффуз, имловий луғат ва грамматик нормаларини эгаллашини тушуниш лозим бўлади. Нутқнинг тўғрилиги унинг энг мухим алоқавий фазилатидир. Нутқ тўғри бўлмаса бошқа коммуникатив сифатлари хам вайрон бўлади. Нутқнинг тузилиши тўғри бўлмаса, унинг мантиқийлиги, аниқлиги, мақсадга мувофиқлигига хам путур этади. Нутқ тўғри бўлиши учун, асосан, икки нормага - урғу ва грамматик нормага қаттиқ амал қилишни талаб қилади. Сўзлардаги урғунинг кўчиши билан маъноси хам баъзан ўзгариб кетиши мумкинлигини эсдан чиқармаслик керак. Бу хам нутқнинг бузилишига олиб келади: Олма - олма, present - present ва х.к.

Гап таркибидаги бир сўзга тушадиган мантиқий урғуни хам маънони фарқлашдаги хизмати катта.

Грамматик нормага риоя қилиш деганда гап тузиш қоидаларидан тўғри фойдаланиш, ўзак ва қўшимчаларни қўшишда хатога йўл қўймаслик, келишик қўшимчаларини ўз ўрнида қўллаш, эга ва кесимнинг мослиги, иккинчи даражали бўлакларни уларга боғланиш қонуниятлари тушунилади.

2. Нутқнинг аниқлиги- бу сўзнинг ўзи ифодалаётган воқеликка мутлақо мос ва мувофиқ келишидир. Аниқлик нутқнинг мухим фазилатларидан бири сифатида қадимдан маълум. Ғарб мутафаккирлари хам, Шарқ олимлари хам аниқликни нутқ сифатларининг биринчи шарти деб хисоблаганлар. Арасту: “Агар нутқ ноаниқ бўлса, у мақсадга эришмайди”, - деган бўлса, Кайковус: “Ей фарзанд, сўзнинг юз ва орқа томонини билгил, уларга риоя қилгил, сўзлаганда маъноли гапир, бу нотиқликнинг аломатидир. Агар гапирган вақтингда сўзнинг қандай маънога эга эканлигини билмасанг қўшга ўхшайсан...” дейди.

Аниқлик нутқнинг фазилати сифатида ёрқин ифодалаш қобилияти билан, нутқ предметининг маъноси билан, нутқда ишлатилаётган сўз маъноларини билиш билан боғлиқ бўлади.

Агар нотиқ ўзи фикр юритмоқчи бўлган нутқ предметини яхши билса, унга мос сўзлар танласа ва ўзи танлаган сўзларнинг маъноларига мос вазифалар юкласа нутқ аниқ бўлиши тайин. Аниқлик икки хил бўлади: нарсанинг аниқлиги ва тушунча аниқлиги.

3. Нутқнинг мантиқийлигиунинг асосий сифатлари тўғрилик ва аниқлик биланчамбарчас боғлангандир. Чунки грамматик жихатдан тўғри тузилмаган нутқхам, фикрни ифодалаш учун муваффақиятсиз танланган луғавий бирлик хаммантиқнинг бузилишига олиб келиши табиийдир. Мантиқий изчилликнинг бузилишитингловчи ва ўқувчига ифодаланаётган фикрнинг тўлиқ бориб этмаслиги, баъзанумуман 
англашилмаслигига олиб келади. Нутқни тузишдаги эътиборсизлик натижасидабаъзан, хатто, мантиқсизлик юз беради. Хулоса қилганимизда, нутқнинг матиқийлиги деганда, яхлит бир система асосида тузилган, фикрлар ривожи изчил бўлган, хар бир сўз, ибора аниқ мақсадга мувофиқ равишда ишлатиладиган нутқни тушунамиз.

4. Нутқнинг тозалиги. Нутқнинг тозалиги деганда, энг аввало, унинг адабий тилнинг лисоний нормасига мувофиқ келиш келмаслиги тушунилади.Дархақиқат,яхши, идеал нутқ хозирги ўзбек адабий тили талабларига мос холда тузилган бўлиши,турли тил, ғайри адабий тил унсурларидан холи бўлиши керак.Бу масаланинг лисонийтомони бўлиб, нутқий тозаликнинг нолингвистик жихатлари хам ундан кам бўлмаганахамиятга эга.

Нутқимизнинг тоза бўлишига халақит бераётган лисоний унсурлар, асосан, диалектизмлар ва варваризмлардир. Тўғри, улар тилимизда ишлатилиши керак, бусиз бўлмайди. Чунки, бадиий адабиёт тилида диалектизм ва варваризмлар билан маълум бадиий-естетик вазифани бажариши, муаллифнинг маълум ғоясини, ниятини амалга оширишга хизмат қилиши мумкин. Айтайлик, миллий калоритни бермоқчи ёки асар қахрамонининг қаерлик эканлигига ишора қилишда диалектизм ва варваризмларга мурожаат қилиши, хатто, зарурдир.

Паразит сўзлар деб аталувчи луғавий бирликлар хам тил маданияти учунётдир. Улар, асосан, сўзлашув нутқида кўп ишлатилиб, нотиқнинг ўз нутқиникузатиб бормаслиги, эътиборсизлиги натижасида пайдо бўлади ва бора-бора одатгаайланиб қолади.

5. Нутқнинг таъсирчанлиги. Нутқнинг таъсирчанлиги деганда, асосан, оғзакинутқ жараёни назарда тутилган ва шунинг учун унинг тингловчи томонидан қабулқилинишидаги рухий вазиятни эътиборга олиш хам мухимдир. Яъни, нотиқтингловчиларни хисобга олиши кишиларнинг билим даражасидан тортиб, хаттоёшигача, ўз нутқининг тингловчилар эшитаётган пайтдаги кайфиятигачакузатиб туриши, ўз нутқининг тингловчилар томонидан қандай қабул қилаётганининазорат қилиши лозим бўлади. Профессионал билимга эга бўлган кишилар олдида жўн,содда тилда гапириш мақсадга мувофиқ бўлмагани каби, оддий, этарли даражадагимаълумотга эга бўлмаган тингловчилар олдида хам илмий ва расмий тилдагапиришга харакат қилиш керак эмас. Хуллас, нотиқдан вазиятга қараб иш тутишталаб қилинади ва ифодаламоқчи бўлган фикрни тўлалигича тингловчиларга этказишга харакат қилиш вазифа қилиб қўйилади.

Демак, хорижлик мехмонлар билан ўз иши жараёнида доимий мулоқотда бўладиган гид-таржимон нафақат ўз тили ва чет тил бўйича мукаммал билимга, балки чиройли нутқ маданиятига хам эга бўлиши керак. Бу борада нутқ маданиятининг асосий талабалари бўлган нутқнинг тўғрилигига, аниқлигига, мантиқийлигига, тозалигига, таъсирчанлигига амал қилиши бугунги кундаги профессионал гид-таржимонларнинг асосий вазифалардан хисобланади.

\section{Адабиётлар:}

1. Арипова А.Х. Нотиқлик нутқининг лисоний-услубий воситалари: Филол. фан. номз. дис. Тошкент: ЎзРФА, Алишер Навоий номидаги Тил ва адабиѐт институти, 2002. - 170 б.

2. Белый В.В., АксеноваГ. Н. Культура речи молодого врача: учеб.-метод. пособие /. - Минск : БГМУ, 2011. -100 с.

3. Гиро П. От риторики к стилистике// Новое в зарубежной лингвистике. - М.: Прогресс, 1980. - C. 35-40.

4. Хожиев А. Лингвистик терминларнинг изохли луғати. -Т., 1985. - Б. 62. 


\section{INTERNATIONAL TOURISM DEVELOPMENT}

\section{Emmanuel Egbeiyon \\ Ph.D. Chair department of foreign languages University of Benin, Edo state. Nigeria E-mail: emmanuelegbeiyon987@gmail.com}

Annotation: The analysis of trends in the development of international tourism, which is one of the main sources of foreign currency and occupies an important place among export earnings, is carried out. The issue of investing in the development of tourism in most countries is considered, which helps to turn it into the main driving force of socio-economic progress through the creation of jobs and enterprises and the development of infrastructure. Tourism as a source of international trade in services, which has become one of the world's largest trade categories, is studied.
Key words : tourism development, tourist destinations, investment in tourism, Ukrainian tourists.

An increasing number of countries are investing in tourism development, making modern tourism a major driver of socio-economic progress through the creation of jobs and enterprises, infrastructure development, and revenue from services exports. As a source of international trade in services, tourism has become one of the world's largest trade categories. The total equivalent of exports generated by inbound tourism, including passenger transport, exceeded $\$ 1$ trillion in 2010 , or about $\$ 3$ billion. in the day.

Tourism and related services for export account for about $30 \%$ of global exports of commercial services and $6 \%$ of total exports of goods and services. Tourism as an export category ranks fourth in the world after exports of fuel, chemicals and automotive products. For many developing countries, it is one of the main sources of foreign exchange and ranks first among export earnings, which creates numerous jobs and opportunities for further development.

The purpose of the article is to analyze and systematize statistical indicators of tourism for individual regions defined by the world tourism organization (UNWTO) for 2010 and the first months of 2011.

To achieve this goal, the following tasks are set:

- conduct a digital analysis of the contribution of tourism as an industry to the global gross domestic product (GDP);

- conduct a statistical analysis of international tourist arrivals after the global economic crisis of 2009;

- to conduct a digital analysis of indicators of international currency receipts from tourism in 2010 and a comparative characteristic since 2009.

The contribution of tourism to world GDP is estimated at about $5 \%$. The contribution of tourism to solving the employment problem is slightly higher - about 6-7 \% of the total number of jobs worldwide (direct and indirect). The share of tourism in GDP is about $2 \%$ for countries where tourism is a relatively small sector, to more than $10 \%$ for countries where tourism is an important element of the economy. For small Islands, where tourism is a key sector of the economy, its importance for economic development is usually even higher [1]. UNWTO consists of 154 countries, 7 territories and about 400 associate members (branches). In 2010, there was a high rate of recovery in international tourism. The number of international tourist arrivals increased by $6.6 \%$ to 940 million tourists after a $4 \%$ decline in 2009 , during which the impact of the global economic crisis was most acute. International tourism revenues reached \$ 919 billion in 2010. worldwide (693 billion Euro), compared to \$ 851 billion. (610 billion.Euro) in 2009 [1].

In real terms, the amount of income from international tourism, taking into account currency fluctuations and inflation, increased by $5 \%$, and the volume of arrivals - by almost 
$7 \%$, which indicates a close relationship between the two indicators and confirms that during the recovery period, arrivals tend to recover faster than receipts [2].

As a reflection of economic conditions, the recovery was particularly strong in emerging economies, where arrivals grew faster (+8 \%) than in developed countries $(+5 \%)$. During the first two months of 2011, compared to the same period last year, there was an increase in the arrivals of foreign tourists by almost $5 \%$. According to the UNWTO forecast [1], international tourist arrivals will increase by 4 to $5 \%$ in 2011. The impact of events in North Africa and the middle East, as well as the devastating earthquake and tsunami that struck Japan in March 2011, should not significantly affect this overall forecast.

Over the past sixty years, tourism has continuously diversified and become one of the largest and fastest growing economic sectors in the world, because tourist arrivals have shown almost continuous growth: from 25 million in 1950, to 277 million in 1980, to 435 million in 1990, to 675 million in 2000, and the current 940 million visitors to destinations. The growth was particularly noticeable in developing regions, where the share of international tourist arrivals rose steadily from $31 \%$ in 1990 to $47 \%$ in 2010 .

The number of international tourist arrivals increased by $4.5 \%$ in the first four months of 2011 and there was positive growth in all regions except the Middle East. In some sub regions, double-digit growth was achieved, namely in South America (+17\%), South Asia $(+14 \%)$ and South-East Asia (+10\%) [3]. Global tourism continues to strengthen the recovery in 2010, despite the impact of recent events in the middle East and North Africa, as well as the tragic events in Japan, which temporarily have a negative impact on tourist flows to these regions. UNWTO expects that tourism destinations that are currently experiencing difficulties will see a recovery in demand by the end of the year.

In the period from January to April 2011, 268 million international tourist arrivals were registered in tourist destinations worldwide, which is almost 12 million more than the 256 million arrivals registered in the same period in 2010. The highest growth rate was achieved in April, at $6 \%$. This is due to the late Easter holiday and is in sharp contrast to the downturn in April 2010, when European airspace was closed for almost a week due to an ash cloud formed by a volcano eruption in Iceland. January of this year also turned out to be a dynamic month $(+6$ $\%$ ), while in February and March the dynamics were at the level of $+3 \%$ [3].

Europe exceeded expectations (+6\%) and achieved the highest growth rate in the first four months of 2011. These results reflect a slow recovery in various European tourist destinations and in the markets of the sending countries, a late Easter holiday, and compensation for the negative performance in April 2010 due to the negative impact of the volcanic ash cloud. Particularly good results were achieved in tourist destinations in Northern, Eastern and southern Europe.

The growth rate in Asia and the Pacific (+5 \%) was in line with the global average, but was slightly lower than previously projected. Asia, particularly North-East Asia, was affected by the earthquake and tsunami in Japan, which affected both inbound and outbound tourism and intraregional tourist flows from other markets.

In the Americas, international tourist arrivals increased by $5 \%$, driven by strong results in South America, which were in sharp contrast to the low average growth rates for tourist destinations in North and Central America.

The middle East (-14\%) and North Africa (-11\%) have been significantly affected by recent political events. However, some tourist destinations in the Middle East, such as Saudi Arabia and Dubai (United Arab Emirates), showed particularly positive results, demonstrating the dynamism of the sector in the region. In Africa $(+2 \%)$, tourist arrivals to sub-Saharan African countries are highlighted (+8\%). The results of North-East Asia, North Africa and the Middle East are lower than initially forecast, but at the same time, the results of destinations in Europe and South America are still better than expected. In General, and as is usually the case 
in similar situations, there is likely to be a temporary reallocation of traffic and an increase in the volume of intra-regional trips compared to the volume of inter-regional trips.

In the top ten of international tourist spending, China has moved up to the third position. Since 2000, China has managed to increase tourist spending four times, which is why it has achieved the highest growth rates in this category over the past decade, especially since, thanks to the constant increase in the solvency of Chinese citizens, tourists from this country are becoming more numerous in almost all economically developed countries, especially during periods of seasonal discounts, sales, etc. Other changes in the ranking of international tourism expenditures include the move to higher positions in Canada and Australia, at 6 and 10 places, respectively.

China also strengthened its position in the ranking of the top ten destinations in terms of international tourist arrivals and revenue. In terms of arrivals, China has overtaken Spain and now ranks third after France and the United States, and in terms of receipts, it has reached the fourth position, surpassing Italy. Another change that occurred in this ranking is related to Hong Kong (China), which has risen from 14 to 9 place in the top ten in terms of income from international tourism. France continues to lead the ranking of the world's largest destinations in terms of arrivals and ranks third in terms of tourism revenue, while the United States holds the first place in terms of tourism revenue and second in terms of arrivals.

The growth rate of international tourism receipts lagged behind the growth rate of arrivals in 2010, which is typical for recovery periods. Among the leading outbound tourism markets, the growing economies of China (+17\%), Russia (+26\%), Saudi Arabia (+28\%) and Brazil $(+52 \%)$ continue to occupy leading positions in terms of the amount of funds spent by tourists abroad. The situation in the traditional sending markets - Australia (+9\%), Canada (+8 $\%)$, Japan (+7 \%) and France (+4\%) - improved, although the US, Germany and Italy have a more modest indicator, namely $+2 \%$. Tourists in the UK in 2010 spent abroad by $-4 \%$.

In 2010, France ranked first in the world among the most visited countries, followed by the United States, China and Spain, fighting for third place. A few years ago, China decided that tourism would be the backbone of its economy, and it worked. The center of attraction of tourism is moving towards China and Asia. In General, by 2021, China will become the most visited country in the world, as well as the main supplier of foreign tourists [4].

Among Ukrainian tourists, the demand for holidays in Turkey is growing against the background of the tense situation in Egypt. As a result of the February events in Egypt, the demand for holidays in such destinations as the United Arab Emirates, Thailand, Israel, and Turkey also increased. However, the high season in Turkey and Egypt do not coincide (for Egypt - September - November, March - may; for Turkey - may - September) and it will be possible to calculate how much the tourist flow to Turkey has increased only by the end of the season. Turkey, along with Egypt, has been a favorite destination for Ukrainian tourists for several years. Every year Turkey is visited by more than 450 thousand tourists from Ukraine. Ukraine and Turkey have agreed to speed up the preparation of visa-free agreements, which will have a positive impact on the development of bilateral relations in trade, tourism and the economy.

Interest in Turkey is also growing among Russian citizens. So, in 2011, this country expects to receive about 4 million Russians, which is $30 \%$ more than in 2010 [5], and it is expected that within five years, Russia will rise from second to first in the number of arrivals of citizens to Turkish resorts, ahead of tourists from Germany.

According to preliminary results [6] in the Crimea in the 2011 season, more than 6 million tourists are expected, which is 5\% more than in 2010. And the authorities of the ARC understand that it is impossible to ensure the development of the resort sector without attracting investment. Therefore, the work of land auctions for the sale of land plots has been resumed. Measures are being taken to ensure environmental development; in particular, a program for environmental safety of the Crimea has been developed. To improve transport 
links, a Charter train "Moscow - Evpatoria" was launched, the duration of the trip on which will be reduced by 6 hours, as well as the modernization of Simferopol airport and the construction of a suburban railway station.

In 2011, investments in the development of the hotel chain amounted to UAH 1.5 billion, which is $40 \%$ more than in 2010. Now in Crimea there are 656 health resorts, more than 2 thousand hotels and mini-boarding houses, 232 tour operators, six water parks, 74 Spa complexes, 446 beaches. In addition, there are 11.5 thousand monuments of history, culture and architecture in Crimea [6].

During the summer, more than 100 different festivals were held in Crimea, including the Yalta film festival, the New wave in Artek, and the Crimean music festival. In addition, from June 2 to 4, Yalta hosted one of the 12 stages of the international rally and this event was visited by more than 300 thousand tourists.

But we must always remember that tour operators engaged in Turkish and Egyptian destinations receive serious support from interested States. For example, in 2010, the country spent between three and five million dollars on advertising Turkey in Ukraine alone.

Tourism has shown itself to be a highly resilient sector, and in order to strengthen integration and cooperation among all participants in the tourism "chain" to increase the competitiveness of the tourism industry, it is necessary to respond more effectively to challenges such as those arising from natural disasters (April 2010) or political instability in Tunisia, Algeria, Egypt (January 2011). The management of the Ukrainian tourism industry constantly needs to conduct proactive and promotional campaigns to attract tourists who are wary of " hot " spots (Egypt, Tunisia, Syria, etc.) to our country for recreation and recreation, testing options for recreation and accommodation "with an eye" on Euro 2012.

\section{References:}

1. Mongkholjuck, C..A Genre Analysis of Tourism Attraction Leaflet Produced and Distributed in Thailand in 2004. Unpublished Masters Thesis, Kasetsart University, Bangkok, Thailand. (2008)

2. Salager-Mayer, F. A text type and move analysis study of verb tense and modality distribution in medical english abstracts. English for Specific Purposes. 11(2),93-113.Retrieved from http://www.elsavier.com/wps/find/journaldescription.cws home/(1991).

3. Santos, M.B.D. The textual organization of research paper abstracts in applied linguistics.Text.(1996).16(1),481-499.Retrieved from

http://www.textjournal.com.au/

\section{ECONOMIC EFFICIENCY OF TOURISM}

Kamal bin Al Khassan

Ph.D.Assistant Professor and Extension Specialist University of the USA in Dubai E-mail: kamal.khasan@gmail,com

Annotation. Efficiency in general, a concept means getting a certain effect, i.e. effectiveness of the result. Economic efficiency is the process of managing, the result of which is expressed by a certain benefit achieved at certain costs of money, material, information resources and labor. The economic efficiency of tourism is an integral element of the overall efficiency of social labor and is expressed by certain criteria and indicators. Under the criterion should be understood the basic requirement to assess the correctness of the solution of the task.
Key words : efficiency, economic efficiency, management, state-wide tourism, tourist company, tourist services, social production, information resources. 
Efficiency in General terms means getting a certain effect, that is, the effectiveness of the result. Economic efficiency is a process of management, the result of which is expressed as a certain benefit achieved at a certain cost of money, material, information resources and labor.

Economic efficiency of tourism means getting a benefit (economic effect) from:

\section{* state-wide tourism organizations; \\ * tourist services for the region's population; \\ * production and service process of a tourist company.}

The economic efficiency of tourism is an integral element of the overall efficiency of public labor and is expressed by certain criteria and indicators. The criterion should be understood as the main requirement for evaluating the correctness of the solution of the task. The need for a criterion arises because it should be clearly defined from which positions one should approach the calculation of the efficiency of the production and service process of tourism.

Social production functions in the interests of the whole society, so its effectiveness should be evaluated based on the degree of achievement of the goals of society.

In accordance with the theory of optimal functioning of the economy, the effectiveness of a particular "section" should be evaluated from the perspective of the overall effect, that is, the particular criteria for efficiency should correspond to the global criterion, "follow" from it.

The General criterion for the effectiveness of social production is to achieve the greatest results in the interests of society at the lowest cost of funds and labor. Problems of tourism efficiency should be considered using a systematic approach. The system approach involves setting different criteria and indicators for different levels of management and a certain hierarchy of goals and, accordingly, performance criteria. The organizational structure of tourism management consists of a number of links:

${ }^{*}$ systems as a diversified intersectoral complex of social and household

infrastructure;

* industries as an independent economic link in the region;

* a tourist business entity (travel company).

Therefore, the problem of determining the national economic criterion for the effectiveness of tourism should be considered in three aspects:

- at the level of society (national economy as a whole),

- industries,

* a separate travel company.

To formulate the entire set of criteria for the effectiveness of tourism, it is necessary to show how the overall goal of the system at the level of society is divided into the specific goals of individual subsystems. To do this, we use a technique called "tree of goals and criteria", where each goal corresponds to a certain criterion that expresses the measure by which you can judge the success of achieving the goal.

The positive impact of tourism on the state's economy occurs only if tourism in the country develops comprehensively, that is, it does not turn the country's economy into a service economy. In other words, the economic efficiency of tourism implies that tourism in the country should develop in parallel with other sectors of the national economic complex. Tourism is directly involved in creating the national income of the country. The share of tourism in national income is: in Germany - 4.6\%, in Switzerland-10\%. The total contribution of tourism to the country's economy includes both direct and indirect contributions.

The direct impact of tourism on the economy of a country (region) is the result of a tourist spending on the purchase of tourism services and goods. The money spent by tourists at the place of stay creates income, which leads to a chain reaction: expenses-income-expensesincome, etc.

This process means that tourism indirectly affects the economy of the country (region). Tourism generates secondary demand for goods and services. The indirect contribution of 
tourism to the country's economy is reflected in the effect of repeating the cost of tourists to buy services and goods at a certain time and place. This effect is called the "multiplier effect"or " multiplier". The multiplier is the ratio of the deviation from the equilibrium net national product (gross national product minus capital consumption deductions) and the initial change in investment expenditure that caused this change in the real net national product.

We will show the effect of the tourism revenue multiplier in the following conditional example. A group of foreign tourists spends a certain amount in one of the regions of Russia on the services of a travel company and on the purchase of goods and services from other enterprises. Revenue is the revenue of firms and businesses from the sale of services and goods to tourists. The region's revenue is the taxes received from this revenue and left at the disposal of the region. Tourists ' money begins to fully work for the economy of the region when a tourist firm buys local (regional) goods and services. Sellers of these goods and services, having received money from tourists, pay wages from them to their employees, who, in turn, spend it on buying goods and paying for services, etc. The cycle repeats. Part of the money received from tourists goes to pay taxes, create a savings Fund, buy imported goods and goods produced in other regions, that is, it is a drain of money from this cycle.

The multiplier effect of tourism is shown in the fact that as a result of the chain reaction "expenses - income", the income received from one tourist exceeds the amount of money spent by them in the place of stay to purchase services and goods.

According to Swiss scientists, the multiplier of income from the production of tourism services differs significantly depending on the country or region and ranges from 1.2 to 4.0.

Example. The multiplier for the region is 2.5. the Initial growth of investment in the tourism industry is 40 million rubles, while the increase in the net national product from tourist services in the region will be 100 million rubles.

Export of tourism from a country means active tourism for the economy of that country, and import of tourism means passive tourism. The ratio between the cost of a tourist product sold to foreign tourists in the host country and the cost of a tourist product sold by citizens of a given country abroad is the tourism balance of that country. The peculiarity of tourism is that the tourist product produced for export is not exported from the country, but is sold in this country. The consumer of a tourist product himself overcomes the distance separating him from the tourist product of interest.

Tourism as a trade in services on the world market can be called an invisible export. It makes a corresponding contribution to the country's balance of payments.

The share of the amount of cash currency imported by tourists in the total amount of imported currency in 1996 was 5.8\%, while the share of the amount of currency exported by tourists in the total amount of exported currency was $28 \%$, or 4.8 times more, which negatively characterizes the tourist activity of our country. A positive development is the fact that in 1996, compared with 1995, the amount of foreign currency imported by tourists increased by $\$ 0.8$ billion (from 1.4 to 2.2 billion dollars). the amount of currency exported decreased by $\$ 0.7$ billion (from $\$ 9.0$ to $\$ 8.3$ billion), or by $7.8 \%$.

The economic effect of tourism development in the region is primarily reflected in the creation of additional jobs in the tourism industry, increasing employment, and stimulating the development of economically weak regions.

The quality of jobs in the tourism industry has its own characteristics, which include:

* seasonal nature of employment in tourist services to the population;

* significant proportion of part-time employees;

- high proportion of low-skilled manual labor;

* limited opportunities for automation and computerization of jobs in the tourism industry (especially in hotels and restaurants).

The development of the tourism industry in the region and improving the quality of tourist services are an additional source of revenue for the territorial budget. The creation of 
tourism industry enterprises in remote sparsely populated and industrially underdeveloped regions that are of interest to tourists (because of the beautiful landscape, rich hunting grounds, places convenient for sports, etc.) contributes to the development of such regions.

\section{Economic indicators of tourism development}

The formation and development of tourism as an industry is characterized by a system of certain economic indicators that reflect the quantitative volume of sales of tourist services and their quality, as well as economic indicators of production and service activities of tourist businesses.

The system of tourism development indicators includes:

- volume of tourist flow;

- state and development of the material and technical base;

- indicators of financial and economic activity of a travel company;

- indicators of international tourism development.

Tourist flow is the constant arrival of tourists to the country (region). The indicators that characterize the volume of tourist flow include: the total number of tourists, including organized and Amateur; the number of tours (number of nights, bed days); the average duration (average time) of tourists ' stay in the country or region. The number of tour dates is determined by multiplying the total number of tourists by the average duration (in days) of a single tourist's stay in the country (region).

The tourist flow is an uneven phenomenon. To characterize the unevenness of the tourist flow, a coefficient of unevenness is used. Depending on the purpose and task of analyzing the dynamics of tourist flow, three methods are used to calculate the coefficient of unevenness.

Indicators that characterize the state and development of the material and technical base of tourism determine its capacity in a given country (region).

These include: the number of beds in holiday homes, boarding houses, camp sites, hotels, sanatoriums, etc. , as well as the number of beds provided by local residents; the number of seats in the shopping halls of catering enterprises for tourists; the number of seats in theaters reserved for tourists; the number of baths in aquariums reserved for tourists, etc.

Results of financial-economic activity of tourist firm include: sales of tourist services or the revenues from tourism services, the rates of use of labor (labor productivity, level of expenses on payment of labor, etc.), indicators of use of production assets (capital productivity, the turnover of working capital, etc.), the cost of tourism services, profit, profitability, financial indicators of tourist firms (solvency, liquidity, financial stability, monetary self-sufficiency, etc.).

Indicators that characterize the state and development of international tourism are highlighted separately. These include:

- the number of tourists visiting foreign countries (determined by the number of crossings of the state border);

- number of tours for foreign tourists;

* total monetary expenditures made by tourists during foreign trips.

The development of tourism and the increase in the volume of tourism services require a balanced approach, since the social consequences of decisions are very high.

The development of tourism for each country (region) has both advantages and disadvantages.

The advantages are as follows:

- increased cash flow to the region, including foreign currency inflows;

* gross national product is growing;

* create new jobs;

* the structure of recreation is being reformed, which can be used by both tourists and the local population;

* capital is attracted, including foreign capital. 
Disadvantages of tourism development are shown in the fact that tourism:

* affects the growth of prices for local goods and services, land and other natural resources, real estate, etc.

* contributes to the outflow of money abroad for tourist imports;

* causes environmental and social problems.

Uncontrolled development of tourism can negatively affect the environmental situation in the country and change the lifestyle of the indigenous population.

\section{References :}

1. Barometer of international tourism. - Mode of access: http://mkt.unwto.org/ru/barometer.

2. Official site of UNWTO. - Mode of access: http://media.unwto.org/ru/press-release/2011-0512/mezhdunarodnyi-turizm-pervye-rezultaty-2011-goda-podtverzhdayut-usilenie-ro.

3. Official site of UNWTO. - Mode of access: http://media.unwto.org/ru/press-release/2011-0721/mezhdunarodnyi-turizm-sokhranyaet-tempy-rosta-nesmotrya-na-vyzovy.

4. Zyma A. G. Itogi tursezona 2010 I prognozy turisticheskogo rynka / A. G. Zyma / / Biznes Inform. 2011. - No. 1 (393). - Pp. 53-54.

5.http://dengi.ua/news/78287 Ukrainskie turisty promenyali Egipet na Turciyu i OAE.html.

6. http://dengi.ua/news/78540 Krym -gotovitsya prinyat $6 \mathrm{mln}$ turistov .html

\section{TOURISM ON DIFFERENT CONTINENTS OF THE WORLD}

\section{Najd Hassan Raffi \\ Ph.D., Associate Professor \\ Saudi Arabia Jeddah Richmond University London \\ E-mail: susa21563@yahoo.com}

Annotation: Tourism is one of the largest and most dynamic sectors of the economy. High rates of its development, large volumes of foreign exchange earnings actively influence various sectors of the economy, which contributes to the formation of its own tourism industry. The tourism sector accounts for about $6 \%$ of the global gross national product, $7 \%$ of world investments, every 16th workplace, $11 \%$ of world consumer spending. Thus, nowadays one cannot but notice the enormous influence that the tourism industry has on the global economy.
Key words : tourism sector, tourism industry, transport lines and communications, international tourism, organizing tourism, tourist.

A number of important geographical, economic, political and cultural prerequisites contribute to the fact that Western Europe has been and remains the most developed region in terms of international tourism. Here you can identify the following factors:

1) high standard of living for the majority of the population;

2) developed network of transport lines and communications;

3) geographical proximity of European countries from each other;

4) large indentation of the coastline and the presence of bays, bays and inland seas;

5) high urban population density;

6) a large concentration of historical, cultural and natural monuments on relatively small territory;

7) a large number of diverse areas with favorable conditions for recreation, treatment, organization of excursions and travel;

8) extensive experience in organizing tourism.

As in other parts of the world, Western Europe is dominated by intraregional tourism, i.e. the exchange of tourist flows between European countries is higher than between Europe and other continents.

Among the most characteristic features of European tourism is the predominance of flows in the meridional direction, which is expressed in the travel of tourists from the North to 
the South and Vice versa, as well as the concentration of tourists around the Mediterranean basin (including adjacent areas of Asia and Africa). The main reasons for the meridional orientation of tourist flows are the difference in climatic conditions and the variety of landscapes, which, in turn, has left a significant imprint on the life, culture and traditions of the population of the South and North of the region.

However, the meridional orientation of tourist flows tends to decrease due to a large number of trips to neighboring countries, which is usually due to lower travel costs, as well as the desire of tourists to get acquainted with the history, culture, traditions, etc.of neighboring countries. So, in Italy, the majority of tourists are citizens of Germany, Switzerland and France.

In European tourist flows, there is a trend of "anti-podnost", i.e. the desire of southerners to visit the North, northerners to the South, residents of the plains-mountain resorts, citizens of the countryside, etc.

\section{Tourism in Eastern Europe}

In terms of tourism development, the Eastern European region, despite its diverse recreational and educational resources, lags behind the Western European region. This is due to a number of factors:

1) in the countries of Eastern Europe, the process of reorientation of the tourism industry from a planned economy to a market economy is slow;

2) the tourist infrastructure and service level of the Eastern European countries do not meet the modern international requirements and standards adopted in Western Europe in many respects;

3) lack of advertising of the tourist product of many Eastern European countries in the Western market;

4) the relatively low purchasing power of the majority of the population of a number of Eastern European countries constrains the growth of tourist flow from these countries;

5) traditionally tourist countries such as Greece, Turkey, Cyprus, Malta, Egypt, Spain, etc. successfully compete with Eastern European countries for receiving guests.

6) the negative image of Eastern Europe in connection with the conflict in the countries of the former Yugoslavia.

International tourism in the Americas. This includes 2 major regions: North America, Latin America, and the Caribbean Islands. Tourism has been most developed in the United States, Canada, and Mexico. An important role in this process is played by the Caribbean Islands, which attract visitors with their exoticism.

North America. The large share of North America in the world tourism movement is associated with a number of favorable factors. Including:

- favorable geographical position of the region between three oceans: the Atlantic, Pacific and Arctic;

- a huge territory with extremely diverse landscapes, rich recreational resources, a variety of historical, cultural and economic objects;

- a high degree of economic development of countries, including tourist infrastructure, including all types of transport, which contributes to the movement and accommodation of tourists, the organization of services.

An important role was played by the fact that for a long time after the Second world war, the United States was the leading capitalist country, along with Canada, had the highest living standards in the world. It should also be noted that this English-speaking area contributes to the influx of tourists from almost all countries where English is spoken.

The main tourist flows in North America, as in Europe, are intraregional, i.e. between the United States and Canada. There is a large exchange of tourists with the countries of Central America, especially with Mexico. From overseas areas, Europe is the main supplier of tourists to North America, and Asia is also actively involved in this process. 
The seasonality of arrivals of foreign tourists to North America is clear and similar to that in Europe, which is due to the location of these two regions in approximately the same climate zones.

The average length of stay of tourists in General, according to statistical reports, is small, since quite a significant part of visitors from Canada and Mexico arrive in the United States, and from the United States to Canada for only a few days, many are just tourists, i.e. the duration of their stay does not exceed 24 hours. Tourists from overseas spend an average of about two weeks in Canada and the United States.

\section{International tourism in Asia}

Asia is the largest part of the world. More than half of the world's population lives here.

In order to better understand the features of tourism development in this largest part of the world, the following regions should be identified: South-West Asia (middle East), South Asia, South-East Asia, Central and East Asia.

Asia attracts an increasing number of tourists due to the following factors:

- a huge, extremely capacious territory for receiving tourists (Asia is the largest part of the world);

- washing the coasts of Asia with three oceans and dozens of their seas and bays;

- location of this part of the world in all climatic regions, significant diversity and richness of natural landscapes and recreational resources;

- the presence of a huge number of historical and cultural monuments, as well as natural attractions;

— finding the world's most important shrines and pilgrimage centers in Asia;

- ethnic diversity of the continent;

- finding the countries with the highest population in the world in Asia: China, India;

- rapid economic development of a number of countries: Singapore, Japan, South Korea, Malaysia, China, etc.

Along with these favorable conditions, there are a number of negative factors that hinder the development of tourism in Asia. First of all, it should be noted:

- unfavourable natural conditions for tourism in the vast territories of several countries (deserts, highlands with difficult terrain, jungles, etc.);

- weak development of transport infrastructure in a number of countries;

- the dominance of ideological interests over economic interests in a number of countries, as a result of this, the economic backwardness of these countries, their unpreparedness to receive tourists, lack of service (North Korea, Mongolia, Cambodia, Vietnam, Iran, Iraq);

lack of internal political and economic stability in a number of Asian countries (Afghanistan, Lebanon, Iran, Iraq).

The main purpose of visiting Asia by tourists from other parts of the world is to get acquainted with the culture, historical and natural attractions. Business trips and Congress tourism are most typical for Japan, South Korea, Singapore, and China. For the purpose of treatment and worship of religious values, Israel is visited. External tourism links in Asia are mainly carried out aviation. Most flights are operated by international aircraft airlines, a smaller part - companies owned by Asian countries. Due to the wide range of climatic conditions, there is no specific season of arrivals in Asia, but it can be tracked by individual regions.

The main tourist market for Asia is Europe (among them are the former Metropolitan areas of great Britain and France, as well as Germany, Italy, the Netherlands, and the Scandinavian countries), the United States and Canada. From Africa, the largest tourist flows are from the Maghreb countries to Mecca and Medina, and from East Africa to India, Pakistan and Iran. There are relatively large flows of tourists from Australia and New Zealand, especially to South-East and South Asia. Japan stands out from Asian countries in intra-Asian flows. Flows from Asia to other parts of the world are relatively small, and the Asian tourist market does not 
yet correspond to the huge number of its population. Today, Japanese and residents of a number of countries in South-West Asia leave this part of the world more than others.

South-West Asia. This region covers a vast and extremely diverse geographical, historical, and socio-economic area. This includes 16 States: Afghanistan, Bahrain, Cyprus, Israel, Jordan, Iraq, Iran, Kuwait, Lebanon, Oman, Qatar, Saudi Arabia, Syria, Turkey, United Arab Emirates, Yemen. It should be noted that the conventional concept "middle East" is somewhat broader than "southwest Asia" because it covers the territory of South-West Asia, and Egypt and Sudan. The favorable geographical location of some States and regions is combined with the remoteness and isolation of others; favorable climatic and landscape conditions for tourism and resort business, as well as the variety of recreational resources of some countries - with desert, arid (in most of the Arabian Peninsula) in others. There are also serious political differences: a number of States in the region have preserved monarchies (including absolute ones) with strong remnants of feudal and tribal relations, but the Republican form of government still prevails.

In General, South-West Asia can be considered one of the most promising regions in the development of tourism. The wide access to many seas and bays of the Atlantic and Indian oceans and the Caspian sea, the geographical position at the crossroads of three continents, diverse relief and climatic conditions, a large number of Sunny days, unique natural attractions, many historical, cultural and religious monuments, well-developed tourist infrastructure in a number of States (Cyprus, Turkey, Israel) - all these and many other factors contribute to attracting visitors from other parts of the world, as well as the development of tourism exchanges within the region.

International tourism in Africa. Africa is an extremely interesting, very promising, but the most poorly developed tourist region. Among the factors that favor the development of tourism on this continent, we can highlight the following:

1) proximity to Europe and Asia;

2) warm weather and plenty of sun all year round;

3) the presence of beautiful beaches in many coastal areas of Africa, on the basis of which you can create sea resorts;

4) diverse exotic nature, including unique wild fauna;

5) the diversity of cultural and historical attractions in North Africa.

Among the factors that hinder the development of tourism in Africa are the following:

1) the low economic level of most African countries;

2) poorly developed tourist infrastructure and transport network;

3) unstable internal political situation of a number of countries on the continent;

4) lack of developed domestic tourism, which "paves the way" for international tourism;

5) governments of some countries pay insufficient attention to tourism development;

6) some areas of the continent are characterized by unfavorable climatic conditions (extreme heat, dry weather, a long period of heavy precipitation).

In terms of the development of the placement Fund, Africa is significantly inferior to Europe and North America. The largest development of the placement Fund has been achieved in North Africa and South Africa, and its growth rate is higher here than in other countries of the continent.

Transport is poorly developed. The highest density of paved roads in South Africa, Morocco, Tunisia, and Somalia. In some countries with a dry climate, some of the unpaved roads may be used for tourism. However, in countries located in the Equatorial zone and surrounding areas, it is not possible to use roads without a hard surface during the rainy season. Given that many tourists come from Europe by car and bus, many African governments are paying attention to building new roads and improving existing ones.

The most popular mode of transport for visitors to African countries is aviation. Dozens of flights connect the African continent with Europe, America and other parts of the world. 
A special form of sea tourism - cruises-is developing quite successfully in the region of Africa. This is due to the relatively small distance between the ports of Europe and Asia in relation to the ports of North and West Africa, the location off the coast of attractive Islands for travelers - Madeira, Canary Islands, Cape Verde, the Gulf of Guinea Islands. Using a cruise trip to the Mediterranean, tourists can explore the countries of three parts of the world in one trip.

The seasonality of tourism here depends both on local climatic conditions, especially the position of Africa in the Northern and southern hemispheres, and on global trends in the seasonality of tourism. The main tourist areas of North Africa are located in the coastal parts of are, Algeria, Tunisia and Morocco, i.e. in the subtropical part of the Northern hemisphere. Despite the fact that the maximum number of tourist visits is in the summer months, the number of arrivals there is quite significant in the winter months. Algeria can host guests 9 months of the year (the best months are March may and September November). Morocco is a country of year-round tourism, but even here, although the local winter is preferable for Europeans, summer continues to play a more important role. In the southern regions of Tunisia, the season lasts all year round, but in other areas, the tourist season can be considered 8 months. For route tourism in this area, cooler winter months are more convenient. Some discrepancy between the periods of comfortable climatic conditions for tourism and the months of the largest number of arrivals of foreign guests is due to the fact that most holidays in Europe are provided in the summer months, as well as the established tradition.

In the South of the continent in South Africa, located in the subtropical zone and in the zone of tropical trade winds of South Africa, the climatic conditions that affect seasonality are different. Here the main feature is the opposite seasons of the Northern hemisphere. The coast of South Africa is characterized by a mild and even climate with annual amplitudes of less than $10^{\circ} \mathrm{C}$, but in the interior of the country, precipitation decreases and temperature fluctuations increase. The maximum increase in tourism in South Africa occurs in the local summer (from the second half of November to the end of February) and in the late autumn (April). However, in winter, especially in July and August, many tourists come here. Summer" peaks " of tourism are explained by the fact that heat lovers go to the southern hemisphere in December and February. The" peaks " of April are associated with the fact that at this time in South Africa there is excellent weather, and the increased arrival of tourists in July and August-with the opportunity to ski in the mountains, where snow lies for several winter months, as well as with the influx of traditional holidaymakers from Europe.

Countries in the Equatorial zone, which extends South and North of the equator at 56 degrees, and East to the Great lakes, with annual temperature variations not exceeding $45^{\circ} \mathrm{C}$ and with alternating two rainy seasons and two relatively dry, and the country areas of Equatorial monsoons of the Northern and southern hemispheres with wet and dry seasons, characterized by an increase in the number of tourists in the dry season. So in Nigeria, the tourist season lasts from October to may.

Thus, due to its position in two hemispheres, Africa has broad prospects for the development of tourism throughout the year, alternating between months of receiving foreign guests, then one, then another country.

\section{References:}

1. Agorni, M. 'Tourism communication: The Translator's Responsibility in the translation of cultural difference. PASOS. Revista de TurismoPatrimonio Cultural. (2012). 10 (4), 5-11

2. American National Standard for Writing Abstracts. (1979). ANSI/NISO, 239.14-1997.

3. Bhatia, V. K. Analysing genre: Language use in professional setting. London: Longman (1993).

4. Chanpetch, J. A Genre Based Analysis on Rhetorical Pattern of Travel Articles in Tropical Magazine. Unpublished Masters Dissertation, Kasetsart University, Bangkok, Thailand. (2011).

5. Connor, U. Contrastive Rhetoric:cross-cultural aspects of second language writing. Cambridge: Cambridge University Press. (1996).

6. Connor, U. Intercultural rhetoric research: beyond texts. Journal of English for Academic Purposes, (2004) 3(4) p (291 304). 


\section{QUELQUES RECOMMENDATIONS POUR LES ACTEURS DU TOURISME LORS DE LA FERMETURE DES ENTREPRISES}

\section{Michel HARTBROT \\ Enseignant en charge des relations internationales École Hôtelière de Paris Lycée Jean Drouant}

COMMERCIALISATION ET COMMUNICATION. Oubliez votre chiffre d'affaires pour les prochaines semaines. Les seuls qui feront une bonne année sont les vendeurs de pâtes et de paracétamol... Vous allez ruiner votre réputation et esquinter votre force de vente si vous prospectez en ce moment. Vous risquez de perdre sur tous les tableaux : Le CA sera perdu mais vous allez détruire votre image auprès de vos clients et perdre vos commerciaux/commerciales. Tout ce que vous pouvez faire c'est appeler des prospects en leur disant : « je n'ai absolument RIEN à vous vendre, je veux juste vous informer sur nos solutions pour qu'une fois sorti de ce terrible épisode vous puissiez prendre les bonnes décisions. En outre, cela nous permet d'oublier cette épreuve et de rester en activité. On peut se faire un entretien par skype ? » Et puis appelez aussi vos clients juste pour prendre de leurs nouvelles!

Envoyez des messages types et personnalisés à vos clients :

- «Nous espérons que vous allez tous bien et que vous êtes en sécurité. Suite aux nouvelles consignes de notre Président, l'équipe du Cercle reste mobilisée pour continuer à assurer vos livraisons de repas tout au long de la journée pour vos astreintes, réunions de gestion de crise, restaurants d'entreprises fermés... Pendant toute cette période nous vous proposons un menu qui change chaque jour, livré dans un emballage à usage unique. Vous pouvez programmer vos livraisons de la semaine pour 10 ou plus de 1000 personnes au : 01.84.25.14.00 ou contact@lecercle.fr Plus que jamais, nous sommes à vos côtés et vous garantissons des produits et livraisons sécurisés. Nous espérons vous revoir très vite pour de meilleurs moments ensemble.»

- «Suite aux annonces du gouvernement, et afin de protéger la santé de nos hôtes et de nos collaborateurs, l'Hôtel Lutetia fermera malheureusement temporairement ses portes à partir du 17 mars 2020. En ces temps troublés, nos coeurs accompagnent nos voisins parisiens, nos clients, nos équipes et tous ceux affectés autour du globe. Nous vous remercions pour votre fidélité et votre présence infaillible à nos côtés depuis notre réouverture. Nous espérons sincèrement vous accueillir de nouveau très vite au Lutetia. À bientôt sur la Rive gauche. »

- "Following the latest announcements of the French government and in order to protect the health of our guests and staff, Hotel Lutetia will sadly be temporarily closed from 17 March 2020. At this difficult time for all, our hearts are with our Parisian neighbours, our guests, our colleagues and all people around the globe. We thank our guests and colleagues for their loyalty and commitment to us and we look forward to reopening and welcoming all to Lutetia as soon as possible. »

Désigner un seul porte-parole compétent, crédible et efficace pour toutes les questions autres que la santé.

Soyez transparent. C'est la meilleure façon de surmonter cela d'un point de vue marketing, L'incertitude peut causer de la confusion et de la panique. Être transparent montre à chacun qu'il est possible de vous faire confiance.

Centralisez les informations. Créer un blog mis à jour ou une page de destination sur votre site Web pour partager toutes les mises à jour de l'événement. Les médias sociaux peuvent également être utiles, mais assurez-vous d'épingler les dernières mises à jour en haut de la page.

Ne supprimez pas. Plutôt que de supprimer, il suffit de publier des mises à jour claires. Le fait d'avoir ces anciennes mises à jour aidera l à comprendre le processus qu'il a fallu 
pour arriver à ce point. Cela aide également à comprendre avec vous que cette décision n'a pas été prise à la légère

Utilisez d'abord le courrier électronique. Le courrier électronique est le moyen le plus efficace de communiquer en ce moment. Il est facilement consultable en temps réel. C'est aussi le plus polyvalent, car vous pouvez inclure de nombreux liens vers des ressources et des informations. "

Établissez une périodicité et informez. Il est important de dire aux clients, fournisseurs et aux parties prenantes à quelle fréquence vous prévoyez de communiquer avec eux et où les mises à jour peuvent être consultées.

Communiquez via les médias sociaux et surveillez-les. Pendant une crise, vous êtes susceptible de recevoir de nombreux messages, commentaires et questions. Il est essentiel que les coordinateurs d'événements adoptent une approche proactive et consacrent des ressources à la surveillance et à la réponse à ces requêtes.

Faites preuve d'empathie. Aborder la messagerie avec empathie, par opposition au marketing pur.

La cohérence est la clé. Toute information, qu'il s'agisse de nouvelles ou de politiques de remboursement, doit être communiqué sur toutes les plateformes.

CAS PARTICULIER DE LA E-REPUTATION . Le confinement a aussi une influence sur le fonctionnement des plateformes d'avis. TripAdvisor n'a rien changé à ses fonctionnalités pour l'instant. Une page spéciale Covid a été créée à l'intention des voyageurs. Dans un récent e-mail envoyé aux propriétaires, TripAdvisor annonçait vouloir mettre en avant les efforts fait par certains pour garantir la sécurité sanitaire. D'ici à ce qu'un logo 'covid-safe' apparaisse, il n'y a qu'un pas. Booking.com annonce une baisse de $85 \%$ de son volume de réservations, et le dépôt d'avis a lui aussi baissé drastiquement. Il n'y a en effet pratiquement plus d'avis déposés depuis le début de la crise sanitaire. Lors de l'annonce de la fermeture des restaurants, Google a d'office indiqué 'établissement fermé temporairement' sur toutes les fiches restaurants, avec plus ou moins de réussite puisque certains se sont retrouvés par erreur avec la mention 'fermé définitivement' (pensez à vérifier votre fiche Google My Business). Google a ensuite fermé la possibilité de répondre aux avis. Les utilisateurs peuvent toujours déposer des avis, mais les gérants ne peuvent plus y répondre.

Que faire pendant le confinement ? Il n'est pas temps de solliciter des avis. Ce n'est pas le moment d'embêter vos anciens clients. Votre communication devrait plutôt être désintéressée et sincère. Il est en revanche possible de prendre le temps de répondre à d'anciens avis. Inutile en revanche de répondre à tous les avis des trois dernières années.

Essayez de faire un peu de nettoyage. Repassez sur vos avis et détectez les avis litigieux pour tenter de les faire supprimer. Attention, les équipes de modération de la plateforme sont elles aussi confinées.

Pendant que vous repassez sur vos fiches, profitez-en pour les enrichir, les mettre à jour. Changez vos photos, descriptifs, vérifiez vos coordonnées. Enfin, profitez du temps à votre disposition pour vous former. Il y a des webinaires et des formations en ligne (MOOC) traitant de l'e-réputation hôtelière, c'est le moment.

Comment répondre aux avis négatifs ? Si l'avis date d'avant la crise et n'est pas en relation avec le confinement, alors répondez comme d'habitude. Si l'avis a été posté après le début du confinement et s'il est en lien avec votre politique d'annulation, expliquez les faits, justifiez vos choix, assumez. Appuyez-vous sur l'ordonnance du 25 mars pour justifier un report de réservation et non un remboursement. Précisez (si c'est vrai) que toutes les demandes sont traitées au cas par cas, que vous aimeriez rembourser tout le monde, que vous faites de votre mieux, que vous ne pouvez pas pallier l'absence de responsabilité de leur assurance voyage (sur la CB). La situation est complexe pour tout le monde. 
Si un avis négatif, relatant une plainte de non-remboursement, est publié et que vous sentez que l'avis est là pour vous mettre la pression, signalez-le comme tentative de chantage auprès de la plateforme.

Faut-il répondre aux avis positifs ? Là encore, il n'est pas question de répondre à tous les avis depuis l'été dernier. Toutefois, cela constitue un excellent moyen de garder le contact avec votre audience. Votre établissement est fermé, il n'est pas réservable, il a disparu de la Toile. Mais il n'en est pas mort pour autant, il est juste en sommeil. Répondre aux avis est un moyen de montrer que vous êtes là, que vous vous occupez de votre établissement. Répondez au dernier avis positif pour donner des nouvelles, dire que tout va bien, que l'équipe est confinée. Communiquez sur ce que vous faites pendant ce temps-là, les améliorations, créez de la vie! Restez positif, joyeux et dynamique.

N'oubliez pas, une fois la crise passée, de supprimer cette réponse. S'il n'y a pas eu de trace du Covid-19 sur votre page, il ne faudrait surtout pas que vous en laissiez une !

Enfin, à la reprise, publiez une réponse à l'avis le plus récent pour rassurer tout le monde. Encore une fois, dites que tout va bien, que l'établissement est rouvert, qu'il fait beau, que toute l'équipe va bien et est sur le pont, que vous avez tout nettoyé à fond... Parlez aussi de l'environnement, la nature, le beau temps, les bars ont dressé leur terrasse, etc. Rendezvous désirable, donnez envie et montrez que vous être prêt à recevoir !

\section{WORLD TOURISM ON TIME COVID - 19}

\section{Alejandro Pastrana President of the company "Gedepsa"}

It is clear that tourism is a sector that will continues to increase, for the same reason that in developed societies people is producing more in less time, so these persons need to use this free time and, one way is the tourism.

Therefore, tourism is a sector with a good present and an excellent future and at the same time a job creator. What can also be assured in the time being, is that it will effectively be influenced by the effect of the virus COVID 19 , that is, because of the virus, new protocols will have to be created, which in turn will bring new routines that were unknown to date and therefore, new opportunities and components will appear that intervene in the whole that is tourism. All this information is supposed to be valid, as long as a vaccine is not found and the potential tourist is not protected against the virus and is also not a possible transmitter and therefore a COVID19contaminant.

To date, the tourism base was governed by the conjunction of several factors, some of them are namely: Climate. Logistics. Services. Culture, etc.

About the climate factor, little can be said, each country has own conditions and for now they are immutable.

On logistics, if a job can be done, but large structures usually depend on the authorities.

The services factors. Well, from now on, new factors have to be added within the services factors, which is the one we are going to have a more direct impact on and which have to be integrated, such as: Health care

C.1.a Within this factor, at the present time, many countries are requiring potential tourists to test, which can be carried out at origin -more interesting - or at destination, this service is less practical, now both to protect the tourist and the native, it is clear that the use of the tests is necessary. 
C.1.b It will also be necessary to create an insurance policy for the duration of the trip and therefore the creation of clinics and / or hospitals that provide these services, it will be necessary and recommended to start thinking about this new factor.

\section{C.1 Vocational training, in all the links of the chain.}

C.2.a Cooperation with schools and universities in the world's most developed countries in the tourism sector, as is the case of Spain, with a tourist reception in 2019 of 84 million tourists. In this field, the University of Castilla la Mancha-(UCLM), with which there are already cooperation agreements with Samarkand State Institute of foreign languages, and such cooperation is very interesting for Uzbekistan, since tourism in Uzbekistan is a continental tourism, since that it does not have maritime beaches, as is the case of Castilla La Mancha.

C.2.b Vocational training is essential if you want to increase the level of tourism and achieve more selective and qualified tourism, which results in greater appreciation by the tourist of the benefits that the receiving country offers, this creates a current of sympathy between the host and the guests, which favors them to be the tourists themselves on their return to their countries of origin, those who are conductors and propagators of the benefits of the receiving country, in this specific case Uzbekistan. Returning to the origins of the agreements between Samarkand and Castilla La Mancha and more specifically between Samarkand State Institute of foreign languages, and the University of Castilla la Mancha (UCLM) and, analyzing the similarities that the tourism that both Samarkand and Castilla La Mancha receive, in addition to being a continental tourism, adds the most important historical and cultural factor, in the case of Toledo, the capital of La Mancha, it would be very opportune to take advantage of deepening these similarities to acquire knowledge in Samarkand about the Toledo tourist experience.

Summarizing: Tourism is a source of both intellectual and monetary wealth. Tourism createsnew opportunities for employment and development. Tourism is a current of exchange between people of different origins, which is why it serves to broaden the horizons of humanity.

This means that new opportunities will arise on the horizon of the tourism sector and, there will be some countries that will have opportunities to take advantage of this sector, which in turn will serve to develop human relations and cultural exchange, while creating jobs and national wealth.

\section{ТАДЖИКИСТАН - ИСТОРИЧЕСКАЯ ТЕРРИТОРИЯ РАЗВИТИЯ ТУРИЗМА}

\section{Нурали Нурзод \\ кандидат филологических наук, заместитель директора Научно-исследовательского института гуманитарных наук ГОУ «ХГУ имени академика Бабаджана Гафурова»}

Annotation: The article discusses the historical opportunities for the development of tourism in the Republic of Tajikistan. Based on historical monuments, travels of diplomatic representatives of different countries, tourists, the author tries to establish that the current territory of the Republic of Tajikistan in the past was one of the areas with potential for tourism development, and now the Government of the Republic of Tajikistan. the development of rural areas, tourism and folk crafts will revive this historic status of the state and transform the country into a country conducive to the development of tourism and transit.

Известно, что объявление 2018 года «Годом развития туризма и народных ремесел» в Послании Президента Республики Таджикистан вызвало искреннюю поддержку в различных слоях общества, особенно, среди представителей образования и культуры. Эта инициатива, обладающая социально-политической, экономической и
Key words : Tajikistan, tourism, historical territory, historical sources, cultural monuments, tourism development opportunities 
культурной значимостью, дала старт осуществлению ряда достойных начинаний и дел, что привело к возрастанию интереса туристов и путешественников к нашей стране. Предпринятые меры, прежде всего, продиктованы государственными целями, направленными на устойчивое развитие страны и повышение уровня благосостояния населения.

По итогам этого года, ставшего плодотворным для таджикского народа, в очередном Послании Лидера нации к Маджлиси Оли Республики Таджикистан от 26 декабря 2018 года 2019-2021 годы были объявлены «Годами развития села, туризма и народных ремесел». Данное начинание, в первую очередь, свидетельствует о том, что наша страна, в действительности обладает многочисленными возможностями для развития туризма, которые могут быть эффективно использованы, в том числе, и на основе развития села.

Обращение к древним источникам выявляет, что из-за прохождения исторических ветвей Великого Шелкового пути по нынешней территории Таджикистана, наша страна с давних пор была местом посещения выдающихся личностей и путешественников, привлекала внимание мирового сообщества, в частности, ученых и литераторов.

Лидер нации в своем Послании Маджлиси Оли наравне с объявлением 2018 года «Годом развития туризма и народных ремесел», подчеркнул, что в ближайшем будущем необходимо превратить Таджикистан в транзитную страну. Безусловно, эта дальновидная и перспективная мысль, высказанная Лидером нации, содержится также и во многих исторических источниках, ибо географическое расположение нынешнего Таджикистана указывает на то, что и в прошлом его территория была одним из основных и ключевых участков Великого Шелкового пути, и маршрут движения большинства путешественников и торговцев проходил через разные регионы нашей страны. Важные сведения, содержащиеся в книгах, как «Бабурнаме» Бабура Мирза, «Дневник путешествия в Самарканд» Руи Гонсалеса де Клавихо, «Тодж ут-таворих» эмира Абдурахманхана, «Дневник путешествия в Искандеркуль» Абдурахмана Мустаджира и других источниках также свидетельствуют об этом.

Президент Республики Таджикистан, уважаемый Эмомали Рахмон в своей книге «Язык нации - бытие нации» с опорой на книгу Руи Гонсалеса де Клавихо, посла Кастилии при дворе эмира Тимура - «Дневник путешествия в Самарканд» (в 1403-1406 гг.), где указывается на существование географического термина «таджикия», пишет: «Дабир Сияки со ссылкой на «Сафарнаме» Клавихо, посла Кастилии при дворе Тимура пишет: «Как только вошли в город Андхуд (Андхуй-Э.Р.), расположенном в пятидесяти километрах от Джайхуна, в провинции древнего Балха, то вступили на территорию Ирана (великого Хорасана), ибо достигли страны Таджикия, язык населения которой отличается от персидского, и кажется, что произносимые ими слова похожи на персидские». В текст этой цитаты переводчиком внесены изменения, а именно добавлена фраза «находящемся в пятидесяти километрах от Джайхуна, в провинции древнего Балха, то вступили на территорию Ирана (великого Хорасана)». В русском переводе текста этого фрагмента нет, и фраза автора переведена следующим образом: «Этот город относился уже не к Мидийской земле, а к земле называемой Тахикиния (Таджикия - Н.Н.), язык ее чем-то отличается от персидского, но в основном похож на него».

В этой же книге Клавихо, причисляя область Рей к стране Таджикия, пишет: «Потом покорил всю землю и империю Орасании (Хорасан), а также всю землю Тахикинии (Таджикии), называемую Рей...» $(3,142-143)$.

Немецкий таджиковед Александр Гейзер, принимая во внимание это высказывание Руи Гонсалеса де Клавихо, считает, что понятие Тајіquija здесь является эквивалентом нынешнего Таджикистана. Он пишет: «Клавихо, посетив также и 
нынешнюю территорию Таджикистана, берег реки Мургаб (Тодждав), отмечает, что язык населения этих мест отличается от персидского некоторыми словами, однако большей частью это персидский. Более того, Клавихо впервые в европейской литературе упоминает о стране таджиков. По записям Клавихо Мургаб относится к территории «Таджикистана» (Таjiquija). Во всяком случае, он сам образовал это слово с опорой на название местных жителей. Таким образом, название таджик и таджики было известно европейцам уже в начале пятнадцатого века» $(7,15)$.

Заслуживает внимания и то, что во многих книгах путешественников, побывавших на исторической территории современного Таджикистана, описывается богатая природа, уникальные культурные традиции, своеобразные обычаи таджиков его различных регионов, таких как, Хуталон и Бадахшан, Худжанд, Вахшская, Гиссарская, Зеравшанская долины, говорится о существовании древних исторических памятниках, мавзолеях и гробницах, священных местах. В частности, Александр Гейзер в своей статье «Открытие страны таджиков» пишет: «До сих пор дневник воспоминаний баварского путешественника Йохана Шильпбергера не получил верной оценки. Он в 1394-1427 годах предпринимает путешествие на Восток. В частности, посещая Иран и Среднюю Азию, он, подобно Марко Поло перешел через Бадахшан. Этот баварский путешественник лично встречался с Тимуром. В его дневнике воспоминаний приводятся интересные замечания относительно исламских мифов и коранических историй. Кроме того, это первый путевой дневник в европейской литературе, в котором упоминается имя Саади. Самым важным для нас в его дневнике является путешествие в Бадахшан, где местные жители, предки таджиков знакомили его с приемами добычи драгоценных камней. Шильпбергер рассказывает он дружбе и гостеприимстве местных жителей, которые по своей природе были остроумными, также упоминает об их серьезном отношении к незнакомцам. Кроме того, он сообщает об их приемах охоты, которые показались ему сказочными» $(7,14)$.

В древних исторических и географических источниках города Хутталона, в том числе, Мунг (Ховалинг), Тамлият (Старый Туткавул), Паргар (Фархор), Корбандж, Андиджарак, Рустакбек и Сикандара, Хулбук упоминаются как большие и процветающие города, Бадахшан называется золотыми воротами исторической территории Таджикистана, город Худжанд - невестой мира или украшением мира, древний Бутаман - «долиной дервишей» или страной проживания мистиков и ученых. Кроме того, существование древнего Саразма, 5500-летие которого по инициативе Лидера нации отмечается в 2020 году, факты о торговых и культурных связях между кочующими скотоводами и земледельцами Средней Азии доказывают, что этот древний город был одним из участков Великого Шелкового пути. Наряду с этим, упоминание в источниках, как «Бабурнаме» Бабура, «Дневник путешествия в Самарканд» Руи Гонсалеса де Клавихо, «Тодж ут-таворих» эмира Абдурахманхана, «Дневник путешествия в Искандеркуль» Абдурахмана Мустаджира о существовании дороги через Самарканд и Бухару в Худжанд и Истаравшан, нынешний Деваштичский район через перевалы Овучи этого района в село Вешаб Айнинского района, село Оббурдан Горной Матчи и от нее в сторону долины Рашт и Бадахшан, и таким образом в направлении Афганистана, также доказывает, что в древности Таджикистан был одним из огромных участков Великого Шелкового пути. Воспоминания Бабура Мирза, Эмира Абдурахманхана, Абдурахмана Мустаджира об этом древнем маршруте свидетельствуют, что наравне с многочисленными путешествиями по этой дороге, они оставили уникальные памятники, которые сегодня признаны выдающимся историческим наследием. В частности, в селе Оббурдан Горной Матчи, в местности Чашмаи Озах есть петроглиф, приписываемый Бабур Мирзе. На территории села Вешаб Айнинского района существует местность под названием «Санги навишта» (букв:Камень с надписью) с одноименным камнем, надпись на котором также приписывается Бабур Мирзе. В 
процессе сбора таких надписей под руководством академика Ахрора Мухтарова камень отвезли в Национальный музей Таджикистана. Эмир Абдурахманхан, правитель Афганистана, посетивший эту местность в 1900 году (1298 г.х.), в своей книге «Тодж уттаворих» пишет: «... Отсюда отправились в село Овучи, дорога проходила через гору, и каждый, кто приходит со стороны Самарканда, должен перейти ее...» $(1,174)$. Имеется в виду тот самый горный перевал Айнинского района, который по словам Эмира Абдурахманхана был единственным путем для того, кто прибывает из Самарканда.

Капитан Г.А.Арендаренко, руководивший группой во время военной операции вГорной Матче в 1875-1876 годах, сообщая о переходе Эмира Абдурахманхана через перевал Вешаб, называет эту дорогу одним из легкопроходимых горных путей: «Абдурахманхан, который в это время года не мог продолжить свой путь через снежные перевалы Оббурдан, Дарх (Дарг), Зингди (Зиди) или же Мур, перешел через долину Басманда и легкопроходимый перевал Вишаб (Вешаб), и в результате некоторые его спутники получили обморожение» $(2,39)$.

Таким образом, обращение Президента Республики Таджикистан к вопросу превращения Таджикистана в транзитную страну является своевременной мерой, направленной не только укрепление связей нашей страны с мировым сообществом, но и на возрождение исторического и географического статуса нашей страны. Достойное начинание Президента Республики Таджикистан возвестит миру о том, что Таджикистан как преемник великой цивилизации все также сохраняет свое историческое положение, и, объявляя годы развития туризма и народных ремесел, стремится продемонстрировать его путешественникам и ученым.

Наряду с этим, в Таджикистане находятся гробницы и мавзолеи ученых, поэтов и суфиев, которые в свое время прибыли из других городов и регионов и обрели вечный покой в различных городах и селах сегодняшнего Таджикистана. В связи с этим, можно упомянуть Имама Хасана Аскари, Хаджа Мухаммада Башоро, Мира Саида Алии Хамадани, Шейха Абулкасыма Гургани, Султана Увайса Карани, Мавляна Мухаммада Шамсиддина Ибн Маликдода Табризи, Абульхасана Харакани, Шейха Шакика Балхи, Шаха Неъматуллаха Зарраби, Мира Саида Хасана Шах Хамуша, Мира Сайид Джалолиддина Гулдаста и др. Существование легенд и преданий о выборе этих регионов на основе благоприятного климата, пленительной природы и гостеприимных людей свидетельствует о том, что эти выдающиеся личности наравне с выполнением своего предназначения в качестве суфиев и духовных наставников общества, также имели особую привязанность к этому краю.

Президент Республики Таджикистан уважаемый Эмомали Рахмон в качестве защитника исторических памятников и священных гробниц неоднократно поручал ученым изучать биографию этих выдающихся личностей и их литературное наследие. В одном из своих выступлений он отметил, что «Безусловно, трудно сделать окончательные выводы без серьезного научного исследования места рождения и смерти великих суфиев прошлого, однако искренняя приверженность людей, несомненно, является парусом корабля надежды, который выведет их к желанному берегу и познанию истины в бушующем море времени» (4).

В свете напутствий Президента Республики Таджикистан, уважаемого Эмомали Рахмона за последние десятилетия проблема изучения существующих на территории Таджикистана исторических мавзолеев и гробниц стала одним из важных литературно исторических направлений современной науки. Вместе с тем, объявление годов развития села, туризма и народных ремесел расширяет границы изысканий ученых, ибо на территории современного Таджикистана сохранились многочисленные мавзолеи, гробницы, уникальные культурные и исторические памятники, которые нуждаются не только во всестороннем исследовании, но и в широком представлении. Глубокое изучение этого ценного исторического и духовного наследия, его всестороняя 
пропаганда может обеспечить одну из основных линий развития туризма в нашем Таджикистане, что в свою очередь, сделает ощутимым вклад ученых в достижении великих целей, поставленных Лидером нации в связи с объявлением этих исторических годов.

Усилия и начинания Президента Республики Таджикистан, уважаемого Эмомали Рахмона в деле возрождения и восстановления исторических памятников, мавзолеев и гробниц выдающихся представителей науки и суфизма, а также возведения культурных учреждений и парков, создания адаптированных регионов для привлечения туристов по всей стране создает благоприятные предпосылки для развития туризма. За последние пять лет в городе Душанбе восстановлены и созданы несколько парков и культурных комплексов, названных в честь великих представителей национальной истории и культуры, в том числе, «Куруши Кабир», «Рудаки», «Джами и Алишер Наваи», «Фирдауси», «Ахмади Дониш», в городе Худжанде создан исторический комплекс «Калъаи Хучанд» и парк «Камола Худжанди» вместе с домом поэта и его символическим мавзолеем, в городе Кулябевосстановлен Парк и исторический комплекс Мира Саид Али Хамадани, в городе Истаравшане - Калъаи Муг, парк и культурный комплекс, в Айнинском районе - дом поэта Накибхона Туграла Ахрори, в городе Исфара - Парк культуры и отдыха имени Сайфиддина Исфаранги, в Аштском районе - Парк культуры и отдыха имени Махмуджона Вахидова, такие же парки имени Садриддина Айни благоустроены в Зафарабадском районе и городе Бустане Согдийской области. Все это относится к числу мер, которые влияют на развитие туризма и способствуют привлечению туристов и путешественников в нашу страну. Статистические анализы показывают, что за последние пять лет почти полмиллиона иностранных туристов посетили эти благоустроенные места с целью отдыха и знакомства с нашими национальными историческими и культурными ценностями.

В целом, навстречу празднования 30-летия Государственной независимости Республики Таджикистан, этого великого национального праздника, в рамках которого нас ждут великие свершения под руководством Лидера нации, будет продолжена работа для реализации благородных целей, связанных с объявлением 2019-2021 годов «Годами развития села, туризма и народных ремесел», способствующих широкому представлению возможностей туризма в Таджикистане. Уверены, что за этот судьбоносный промежуток истории нации, связанный с двумя целенаправленными программами, наш любимый Таджикистан под мудрым руководством Лидера нации восстановит свой исторический статус, и в качестве страны, обладающей ценным историко-культурным наследием, уникальной природой, красивым горным ландшафтом, как и в прежние времена станет предметом неизменного интереса путешественников и любителей природы, и впредь будет занимать достойное место в плеяде развитых стран мира.

\section{Литературы:}

1. Амир Абдурахманхан. Тодж ут-таворих. Кабул, издательство Майванд, 1390 њ./2011 м.

2. Бухара и Афганистан в начале 80-х годов XIX века. (Журналы командировок капитана Г.А. Арендаренко в Бухарское ханство). Ответ. редактор Н.А.Халфин. Москва: Наука, 1974. 144 с.

3. Рахмон Эмомали. Язык нации - бытие нации. -Душанбе: “Эр-граф”, 2016.- 516 с.

4. Рахмон Эмомали. Речь, произнесенная во время посещения могилы Шамса Табрези. 8 июля 2010 г. Айнинский район.

5. Рахмон, Эмомали. Послание Маджлиси Оли Республики Таджикистан. Душанбе, 22 декабря 2017 г.

6. Рахмон, Эмомали. Послание Маджлиси Оли Республики Таджикистан, Душанбе, 26 декабря 2018г.

7. Гейзер, Александр. Тоджи тиллои (Золотой венец / Сборник статей и очерков об истории литературных связей таджиков со странами Западной Европы и России). Пер. с русского Н.Нурзод.- Худжанд, “Нури маърифат”, 2015. - 160 с. 


\section{САРАЗМ - ОДИН ИЗ ЦЕНТРОВ МИРОВОЙ ЦИВИЛИЗАЦИЯ И ИСТОРИЧЕСКАЯ КРАЕВЕДЕНИЯ}

\section{Эркаев Сафар Абдулхайрович \\ доцент, кандидат исторических наук, ХГУ имени академика Б.Гафурова \\ E-mail: safar.erkaev@mail.ru \\ Искандарова Мадина Набиевна \\ дочент ХГУ имени академика Б.Гафурова Джабборова Курбоной \\ доцент ХГУ имени академика Б.Гафброва}

Annotation: $\quad$ This article discusses Sarazm as one of the centers of world civilization and historical local history. With the discovery of Sarazm in 1976, in the territory of Sarazm in the Panjakent district, the archaeological town of Sarazm was created is considered one of the oldest settlements and evidence of the early development of urban development in Central Asia, this is the first archaeological site of Tajikistan, historiography of the history of Sarazm.
Key words : Sarazm, Penjikent, archaeological town, center, world civilization, historical study of local lore, urban planning, Central Asia, historiography.

«В Саразм хорошо сохранились до наших дней дворцовые и культовые сооружения, общественные и жилые строения 1У - 11 тысячелетия до наших дней. Саразм гордость народов Востока, в том числе таджиков »-- профессор Г.Хайдаров Саразм стал укрепляющим центром межкультурный коммуникаций сквозь призму туризма в Центральной Азии, особенно в Таджикистане и Узбекистане благодаря открытием граница между двумя государствами.д. В Послании Основателя мира и национального единства - Лидера нации, Президента Республики Таджикистан Эмомали Рахмона Парламенту страны было отмечено, что по инициативе Таджикистана Генеральная Ассамблея ЮНЕСКО приняла решение о праздновании 5500-летия древнего исторического памятника согдийцев Саразм в 2020 году.[1,4]. Археологические раскопки подтверждают, что Саразм-древний памятник таджикской цивилизации и мировой материальной культуры. Первые раскопки показали, что памятник городища Саразм относится к 1 У - 11 тыс. до н.э., к эпохе энеолита и бронзового века.Памятник расположен в 15 километрах к западу от города Пенджикента и в 45 километрах к востоку от города Самарканда. Один из жителей села Гурач, ветеран Великой Отечественной войны А.Тайлоновслучайно нашёл двухсторонних бронзового топорик (1972) и это стал поводом изучение истории Саразма.

Саразм расположен в границе между Узбекистаном и Таджикистаном, каждый гор сюда приезжает более 1000 туристов из страны мира, проводится туристические беседы, ответ на вопросу, объяснение на таджикском, узбекском, русским, английским, китайским, французским языками. Саразм стал укрепляющим центром межкультурный коммуникаций сквозь призму туризма в Центральной Азии, особенно в Таджикистане и Узбекистане. Основные группа туристов в Саразм приезжают через Самарканда.

Я родился в сельском совете Саразме, населения региона занимались скотоводством, земледелием-табак, овощи, рисоводством и другие. Когда велось освоение новых земель в Средней Азии для вспашки, в том числе в Узбекистане и Таджикистане в 50-70-е годы прошлого века, не зная место исторических места, многие памятники оказались под угрозой исчезновения. В том числе на местоположении неизвестного ещё научному миру древнеземледельческого памятника Саразм также 
интенсивно шли работы по обработке земель. Люди. Колхозники и местное население часто находили во время работ антикварные вещи. Такие как целые кувшинчики, бронзовые орудия, предметы украшений и прочие, однако, в силу своей неосведомлённости, они не сообщали об этом в краеведческие музей. Однажды в 1972 год один из жителей села Ашурали Тайлонов нашёл бронзовый двухсторонних топорик и обращался директору республиканского музея города Пенджикента.Они не обратили внимание и он сохранил топорика в своем доме. Только в 1976 году со своей дочкой Джамилой во время поездка городу Пенджикента посещал историко-краеведческого музея. Там встречал туристов ученых АН СССР из города Ленинграда, которое обсуждали маленького бронзового топорика на руках похожих своего. И решил рассказать о хранившемся у него в доме более 4 года топоре научному сотруднику музея и гостьям. Ученые АН СССР поручил научному сотруднику Пенджикентскойархеологической базы А.Исхакову, занимавшийся уже несколько лет (с 1947) исследованием многих памятников Пенджикентского района, не теряя времени, сразу организовал разведывательные работы. В следующем году был заложен первый раскоп, где обнаружены строительные остатки, фрагменты гончарной и лепной керамики с росписью, зернотёрки и прочие предметы, относящиеся к эпохе неолита и бронзы. Таким образом, был открыт один из важных исторической памятников эпохи протогородского зарождения на территории СреднейАзии.Саразм-древнейшее поселение оседлых народов Центральной Азии, живших с четвёртого тысячелетия до конца третьего тысячелетия до нашей эры. Название «Саразм» происходит от таджикского словосочетания «сари замин» (начало земли).

Использование материалы краеведение является как один из основных способов воспитанник молодежи в направление национального гордостью и любовь к Родины. Один из краеведческих материал как исторический памятник древности таджикского народа считается Саразм. О историографии истории Саразма было написано много сообщений и книг, научных статей исследователями и они является историческим источниками по изучению истории Саразма. Например, «Абдуллоджон Исаков выдающийся археолог, культуролог и первооткрывателСаразмской цивилизации».Душанбе: Деваштич, 2005.- 124 с. (статей-Нозукой Исакова, Н.Н.Негматова, А.Раззоков, С.Бобомуллоев, Л.Курбонова, Юнус Юсуфи, Т.Солезода, И.Салохиддинова, М.Иброхимова, СолехДадабоев, Л.Джанобилов, А.Шодиев, Н.Собиров, ИсмоилЗарифи, Р.Касыми, ОрифшохиОлимпур, А.Назыров, И.Г.Тер-Оганяьн, М.П.Винокурова, Г.Попырина, ,Е.Н.Кудлаева, С.А.Хоч, Л.Курин, О.Латифи, Абдурауф Рабиев, У.П.Пулатов, А.Д.Бабаев); Инъом Усмони «Панљакент дар масири истиќлолият (Пенджикент в годы независимости)».-Хуљанд:Ношир, 2016.-160с. ( труд состоит из введения, четырех глав. заключения и список источников и литературы), в этой книге освещаются успехи дружелюбий трудящиеся разных народнохозяйственных предприятий города Пенджикента во главе Основоположника мира и национального согласия -Лидер нации, Президента Республики Таджикистана уважаемый Эмомалї Рањмона в годы 25-лет независимости Республики Таджикистана).; «Академик Н.Н.Неъматов ва тамаддуни суѓдиён» (Академик Н.Н.Неъматов и согдийская цивилизация).-Хуљанд: Ношир, 2017.108c.; «Чароѓи равшан, энсиклопедияи олимо низодаи диёри Панљакенти бостонї.Душанбе: БахтLTD. 2009. -260с. (книгасостоит из введения, четырех глав. заключения и список источников и литературы, посвящается об деятельности 150 государственных деятелей, ученых древняя регион Согда города Пенджикента. Во всех исторических периодов таджикского наций населения Пенджикента со своей опыта по производства, ремесло торговля, города строительства, культура, науки, наследия, мыслителей славился врегиона Востока и во всем мире. Они играл большой роль в развитии мировой цивилизации. Эти заслуга является великолепный поощерения для таджикского народа и мира); Бектураев А.,Ќаршиев М. «Шањристан в годы 
независимости».-Хуљанд:Анис, 2017.-292с.(в кните в статьях УмарЁќубзода, СафарЭркаев, А.Бектўраев, КароматиллоБањодуров и другихговоря об истории Шахристана, упоминается материалы об истории Саразма); Эркаев С.А. «Орийларцивилизацияситарихиниўрганиш» (Изучение истории цивилизации арийцев) .-Хужанд, 2006.- 28с.; Буклети «КалъаиХуљанд»(Маљмааифарњангиютаърихи.Хуљанд, 2017. ); Буклети «Саразм» ва «SARAZM 5500» --Душанбе, 2005 (данный буклет опубликован при финансовой поддержке Посольства США в Таджикистане в рамках программы Фонд после поддержке культурного наследия, 2004-2005. Историкоархеологический заповедник Саразм при Пенджикентской Археологической базе ИИА и Э им.А.Дониша АН РТ г.Пенджикент, в ней коротко освещено содержание памятника Саразма с иллюстрацией на двух русском и английском языках).

С открытием Саразма в 1976 года, на территории Саразма Пенджикентского района, в 1977 г. им был создан археологической городок со всеми удобствами, который ежегодно принимал исследователей, археологов, историков, служил лагерем для Таджикско- Советской-Российской, Таджикско-Французской и Таджикско-Американской и других археологической экспедиций. Саразм считается одним из древнейших поселений и свидетельством раннего развития градостроительства в Центральной Азии, это первое археологическое городище Таджикистана, В 2010 году Саразм внесён в Список объектов Всемирного Наследия ЮНЕСКО $[2,116]$. С 1У - по 111 тысячелетие до н.э. Саразм является богатым центром развивающейся торговли и культурного обмена в Центральной Азии. Каждый год руководство вузов и школы Согдийской области организуют экскурсии в Саразм и проводит многочисленных культурнопросветительных мероприятий по изучению родного края и она имеют историческую значению в воспитанию молодежи.

Древнеземледельческий памятник Саразма был обнаружен осенью 1976 года археологом Абдуллоджан Исаковым при помощи колхозника колхоза «Ленинграда» Педжикентского района, участники ВОВ АшуралиТайлонова. Памятник расположен в 15 километрах к западу от города Пенджикента и в 45 километрах к востоку от города Самарканда.Один из жителей села Гурач, ветеран Великой Отечественной войны А.Тайлонов был краеведом и всегда интересовал к истории своего края -Таджикистан. Случайно он нашёл двухстороннихбронзового топорик и это стал поводом изучение истории Саразма. Большая площадь заселения, остатки монументальной архитектуры, производственных центров и храмов свидетельствуют о том, что Саразм является одним из ранних протогородов на Востоке[2,116].

Кроме того, в список памятников ЮНЕСКО попали императорский дворец во Вьетнаме, храмы в Китае, древний базар в Иране, первая исправительная колония в Австралии, построенная в ХУ111 веке и другие объекты в разных странах мира, в том числе праздник «Науруз», «Шашмаком», «Оши Палов», памятник Хульбук, парк «Горы Памира»(площадь 2,5 млн. гектар, здесь расположен 170 рек, более 400 озер, и крайней мере, 1085 ледники, в том числе самый протяженный за пределами полярных регионов ледник в горной долине) и другие. Родина начинается из своего края, место рождения и поэтому материалы края является историческим ценностью и способ интернациональной воспитания молодежи, национального чувства к истории своей Родины и народу.

Напомним, статус «памятника Всемирного наследия» присваивается ЮНЕСКО природному или рукотворному объекту для его лучшего сохранения и популяризации. Этот статус дает дополнительные гарантии сохранности того или иного объекта и повышает престиж территории, на которой он находится.Этого события народ и ученые историки, и археологи Таджикистана ждали давно, можно сказать много лет. И вот в конце ноября 2010 года ценности института истории, археологии и этнографии имени Ахмада Дониша Академии наук Таджикистана пополнил ещё один важный документ - 
сертификат ЮНЕСКО о включении в мировой список исторических заповедников археологического памятника Саразма.

«Мне, как научному обозревателя ТаджикТА (НИАТ «Ховар» - говорит Олег Соболев, - в 1976 году довелось освещать в республиканской печати работу Всесоюзной научной конференции, посвященной 35-летию раскопок древнего Пенджикента. Одним из организаторов экскурсий для участников конференции был Пенджикентский ученый, тогда кандидат исторических наук, Абдулло Исаков (потом стал доктор исторических наук, профессор- С.Э.). С этим человеком были знакомы многие сотрудники нашего агентства. Когда он приезжал в Душанбе, то обязательно заходил в редакцию и показал свои археологические находки» $[3,6]$.

Действительно, Саразм является древний памятник и один из центров мировой цивилизации. На археологическом памятнике Саразма раскопаны остатки жилых, хозяйственных помещений, расчищены улицы и переулки, открыты храмы,мастерские, склады для продукции,печи обжига и другие хозяйственные сооружения.

По данным археологическим раскопки, площадь Саразма занимает более 100 га, материалы, находки свидетельствуют о том, что Саразм является одним из ранних городов на Мавераннахра и жители Саразма, в основном занимались земледелием, скотоводством, рыболовством, охотой, а также народными ремеслами и металлургией. На этом месте были найдены металлические изделия: топоры, кинжалы, ножи, наконечники стрела, рыболовные крючки, иголки. Одежда изготавливалась из шерсти и кожи. Об этом же говорят останки этих изделий. Гончары Саразма с помощью гончарного круга изготавливали чаши, кувшины, кумганы, тарелки, блюда и много другой домашней утвари и другие.

9 ноября 2011 года французский археолог Андри Поль-Франкфорт проведёт в Культурном центре «Бактрия» города Душанбе открытую лекцию «Цивилизация Бронзового века в Центральной Азии: «Саразм». Его лекция основана на результатах раскопок в Саразмекоторые он проводил совместно с кандидатом исторических наук АбдурауфРаззоковым. Специалист по Центральной Азии французский археолог в разные годы занимался археологическим исследованием в Таджикистане, Кыргызстане, Узбекистане, Афганистане, Казахстане, Китае (Синьцзян) и в Южной Сибири. Им опубликовано около 15 книг и статей $[4,15]$.

В 1982 году в столице края города Душанбе состоялся Международный симпозиум, посвященный историко - археологическим проблемам Центральной Азии, где с научным докладом выступил А.Исаков. Именно после его выступления учёные многих стран обратили внимание на уникальный памятник Саразм. Доклад вызвал особый интерес у ученых из Франции, которые долгие годы занимались раскопками древних городов в Южной Туркмении, Иране, Афганистане, Пакистане и др. Саразм считается одним из древнейших поселений, центром мировой цивилизации и свидетельством раннего развития градостроительства в Центральной Азии. Что таил в себе древний Саразм и это есть археологические находки. Это были фрагменты керамической посуды, мелкие бусы и другие находки археологов. Всё это найдено не в древнем Пенджикенте, который был раскопан капитально и уже дал материал об историческом облике средневекового города, а это находки с ещё неизвестного древнего Саразма. АбдуллоджанИсхаков говорил нам,27 июля 1989 года(доктор исторических наук, профессор ГафурХайдаровичХайдаров, космонавт, доцент АбдуллоджанХоджиев, доцент Саид Марофиев, исследователи Мубашир Баширханович Исхакї и Сафар Абдулхайрович Эркаев, председатель колхоза «Навои» Махмарахим Расулов, водитель Рахматджан, ветеран колхоза А.Каршиев) мы изучаем истории Саразма. Когда он повезли нас на экскурсию, я уже мысленно пытался представить себе некое городище, где проложены траншеи. Однако АбдуллоИсхаков повёл экскурсантов на небольшой холм, плоская поверхность которого был размечена колышками, с 
натянутыми на них белыми верёвочками. Он сказал, что это первые двадцать квадратных метров будущих раскопок Саразма. В Саразмхорошо сохранились до наших дней дворцовые и культовые сооружения, общественные и жилые строения 1У - 11 тысячелетия до наших дней. Саразм является древнейшим историческим памятником мирового значения и один из мировой культурной центром мировой цивилизацию. На основе сратиграфии раскопа 2, период существования саразмского поселения был разделён на 4 этапа-Саразм 1,11,111,1У, соответствующие периодам 11-111 (1У0 Намозгах-теппа.[5].

Первая группа ученых под руководством Анри-Пола Франкфорта в 1984 году прибыла в Саразм. Здесь работали много ученых историков, археологов мирового масштаба. Изучая истории Саразма, мы можем говорить о Саразме, как о первом в Республики Таджикистане памятник Всемирного наследия. В публикациях (книги, пресса и др.) о результатах археологических раскопок, отражено, что Саразм является древнейшим поселением 1 - 11 тысячелетия до нашей эры. Расположен на территории Таджикистане Саразм находится в 15 кмк западу от современного районного центра города Пенджикент на левом берегу реки Зеравшан. Большую историческую и культурную ценность представляют хорошо сохранившиеся дворцовые и культовые сооружения,общественные и жилые строения. Согласно заключениям специалистов археологов (Ланберг Карловски, Филим Кол, Вероник Шильц, Ю.А.Заднепровский, Ю.Ф.Буряков, Пол Бернар, А.Аскаров,Б.А.Литвинский, Р.М.Мунчаев,Роланд Безенваль, Анри-Пол Франкфор,Б.И.Маршак, Р.М.Масов и др.), большую историческую и культурную ценность представляют хорошо сохранившиеся дворцовые и культовые сооружения, общественных и жилые строенияв Саразме. На месте раскопок были найдены металлические и каменные изделия, а также многочисленные украшения, изготовленные из драгоценных камней и обработанных морских раковин. Поселение расположено в пределах Бактрийско-Маргиланского археологического комплекса. Разрушение поселения Саразма по времени совпадает с вторжением на эту территорию кочевых индо-иранских племён. Среди известных археологов одним из них был Роланд Безенваль-французский археолог, культуролог, историк, который долгое время работал на раскопкахСаразма. Он умер в 2014 году в Таджикистане[6, 2].

Название Саразмприсходит от древнего таджикского слова «саризамин» (начало Земли). В 70-е годы XX века, когда велись работы по освоению новых земель, к ученым и журналистам стали обращаться, как местные жители, так и колхозники, они сообщили, что под ножи бульдозеров местами попадают интересные археологические объекты, подтверждая свои рассказы предъявлением различных находок, явно древнего происхождения. Итак, в конце 1976 года Абдулла Исаков сообщил в Академию Таджикской ССР и рассказал о сенсационной находке в виде бронзового топорика, Этот топорик был найден в территории региона Саразма жителем села Гурач (Авазали), АшуралиТайлоновым в 1972 и 4 года он у себя сохранил. В следующем году был заложен первый раскоп, где обнаружены строительные остатки, фрагменты гончарной и лепной керамики с росписью, зернотёрки и другие, относящиеся к эпохе неолита и бронзы. Так был открыт один из важных памятников эпохи зарождения древнейших городов на территории Средней Азии и изучение истории Саразма до сих пор продолжается под руководством археолога АбдурауфРаззаковым. Чутьё археолога Абдулло Исакова не подвело и позволило обогатить науку важными данными о развитии на Земле человеческой цивилизации. В 1994 году в городе Душанбе состоялся международный симпозиум посвященный Саразму, было установлено, что культура градостроительства в севера-восточный части Центральной Азии зародилась именно в Саразме. Тщательный поиски первооткрывателяСаразмаА.И.Исакова увенчались уникальный находкой. Раскопки на территории Саразма позволили добыть из земли многочисленные медные, бронзовые и керамические сосуды, ювелирные изделия из золота, рыболовные крючки, 
каменные гири, бритвы, свинцовые печати .Это принесло ему научную степень доктора исторических наук и слава. Саразм внесли в список Всемирного наследия 31 июля 2010 года.

Основатель мира и национального единства-Лидер нации, Президент Республики Таджикистана уважаемый Эмомали Рахмон утвердил символику 5500-летия Саразма. Символ5500-летия древнегоСаразма имеет округлую форму. На нём изображена детали, свидетельствующие, что наши предки были искусными земледельцами, ремесленниками, занимались градостроительством и градоуправлением. На двух сторонах символа слово «Саразм» обозначено на таджикским английском языках, а возраст города - «5500» отображено цифрами.

Двенадцатиугольная золотая находка, являющаяся результатом последних раскопок в Саразме, изображена в центре символа. В середине этой находки изображены древние стены Саразма, построенные з глины. Находка изготовлена с применением высокого ювелирного искусства и олицетворяет Небесное Светило. Круглая зелёная цель указывает на безупречную синеву неба и символизирует атмосферу мира и спокойствия. Если 12 вершиноподобных углов этой находки обозначают 12 вершин небосвода или 12 месяцев года, то создание её в треугольной форме есть символ жизнетворных лучей солнца. Почитание солнца арийцами есть их вера в победу света над тьмой, что означает вечное возрождение Земли.

Продолжительные исследования археологов-историков мира на раскопках Саразма свидетельствуют о том, что одним из сакральных обычаев арийцев, в том числе жителей Саразма, было преклонение перед НебеснымСветилом.

Все детали и знаки символа отражают древнюю историю Саразма и являются вестниками славы независимого Таджикистана.

В заключение хотим сказать, мы предлагали один краеведческих материал на примеры Саразма, нам видночто в Таджикистане существуют 40 музей, 420 туристических объекты культуры и отдыха, более 3050историко-культурные памятники и многие других. Они все является краеведческих материалы и поэтому надо успешно использовать в ходи всех видов занятий, организовать урок - экскурсии, письменные работы (рефераты, доклады, сочинение, диктант, очерк, статьи, эссе, рассказы и другие), кружки, встречи, вечера, неделя молодых краеведов и многие другие, которые имеют большой учебно-воспитательной значение в патриотическом и интернациональном воспитание молодежи.

Саразм является древнейшим поселением оседлых народов Центральной Азии, один из центров мировой цивилизация, древний памятник таджикской цивилизации и древнего города Согдийцев. Живших с четвертого тысячелетия до конца третьего тысячелетия до нашей эры. Саразмрасположен на левом берегу реки Зеравшана Зеравшанского долины. Большую историческую и культурную ценность представляют хорошо сохранившиеся дворцовые и жилые строения $[7,10]$. Изучение истории Саразмасостороне таджикских, узбекских и зарубежных исследователей и организации туризма укрепляет дружба узбекского и таджикского народа и народов мира.

\section{Литературы:}

1.«Народная газета» № 52 (20230) 30 декабря 2019 года.

2.ЭркаевС.А.Саразм-маконисайёхиюфарњангї.-«Ќонунваљомеа», № 31 (536).15.08.2019.Усмонї Ином. Панљакент дар масири истиќлолият.-Хуљанд: Ношир, 2016.-160 с.

3.»Маориф вамаданият» 6 октябри соли 1977.Пенджикент. - Душанбе: Ирфон, 1978,Исаков А.И. Саразм. - Душанбе: Дониш, 1991; Исаков А.И. «Археологические открытия, 1978»,- Москва, 1979;

4.Саразм-гањвораи тамаддуни халќи тољик.-Хуљанд.-16с.

5.Беседа состоялась 27 июля 1989 года

6.«Согдийская правда» № 23 (16837) 18 марта 2020 года. История таджикского народа из 6 тома-Душанбе,1998-2013 НазирљонТурсуниХуљанди «Истаравшан»-Хуљанд, 1992; 
7.Исаков А.И. «Саразм - поселение эпохи полематалла в долини Зарафшан». - Археология Средней Азии и Ближнего Востока.- 11. Советско - американский смимпозиум,- Ташкент, 1983; «Рўйхати мањалњои маскуни вилояти Самарќанд» (1906); Исаков А.И. «Раскопка в Саразме» Археологические открытия, 1979»,- Москва, 1980; Исаков А.И. Раскопки на поселение Саразме.Душанбе, 1982; Исаков А.И. «Саразм - новый ранне земледельческий памятник Средней Азии»,Советская археология.- Москва, 1986,- №1. С. 152 - 167; Эркаев С.А. «Орийлар цивилизацияси тарихини ўрганиш» (Изучение истории цивилизации арейцув) .-Хужанд, 2006.- 28c.;

\title{
КУЛЬТУРНАЯ ДИПЛОМАТИЯ ТАДЖИКИСТАНА \\ В СОВРЕМЕННЫХ МЕЖДУНАРОДНЫХ ОТНОШЕНИЯХ
}

\section{Хошимов Фируз Джаббарович преподаватель Института Экономики и Торговли ТГУК в г. Худжанде E-mail: firuz1805@mail.ru}

\begin{abstract}
Annotation: This article discusses the issues of presenting the culture and ancient history of Tajiks in the international arena, analyzes the role and image of cultural diplomacy in the development of bilateral and multilateral relations of the Republic of Tajikistan in modern international relations. Cultural and historical events conducted by Tajikistan both inside the country and abroad are considered. In addition, the cooperation and achievements of Tajikistan with the influential international organization UNESCO are shown. At the end of the article, the activities of the public organization TODKS were presented as an instrument for the implementation of cultural diplomacy in establishing international relations
\end{abstract}

Key words : culture, diplomacy, Tajikistan, independence, civil war, history, globalization, tourism, UNESCO, TODKS

Культура является неотъемлемой частью любого общества и отражением образа жизни государства. Каждая культура должна развивать симпатию к своей стране, укреплять позитивную роль государство на международной арене, содействовать налаживанию отношений между государствами и людьми, а также вносить большой вклад в улучшении других связей, в том числе экономических.

В современных международных отношениях, в своей внешнеполитической деятельности государства мира широко начали применять «культурную дипломатию», которая характеризуется как «вид публичной дипломатии, включающая в себя обмен идеями, информацией, произведениями искусства и другими компонентами культуры между государствами и населяющими их народами с целью укрепления взаимопонимания»[1, 74].

После распада Советского Союза и с приобретением государственной независимости (9-сентября 1991 года), новая страница открылась в жизни Республики Таджикистан. Но, к сожалению не отметив годовщину независимости, наша страна потерпела гражданскую войну и находилась в состоянии исчезновения государства.

В результате гражданской войны погибли более 150 тысяч человек, а число внутренних переселенцев достигло около 1 млн. человек $[1,2]$. После пятилетнего вооруженного конфликта было подписано «Общее соглашение об установлении мира и национального единства» в Таджикистане (27-июня 1997г.), которое является уникальным национальным достижением в нашей стране.

Сегодня государственную независимость Республики Таджикистан официально признала более 150 государств мира, а на основе этого, Таджикистан подписал и выполняет более 2 тыс. правовых актов с различными государствами мира. Республика Таджикистан является активным членом более 80 региональных и международных организаций. Наряду с этим, Таджикистан присоединился к более 350 международным 
актам, таким как международные конвенции, хартии и резолюции, выполняет свои обязательства в направлении достижения мировых целей, таких как социальное развитие, улучшение экономического положения, защита окружающей среды и т.д. [3].

В годы независимости Республика Таджикистан начала поддерживать миролюбивую и дружескую политику. В частности, эти слова были отражены в статье 11-ой Конституции РТ: «Таджикистан, осуществляя миролюбивую политику, уважает суверенитет и независимость других государств, определяет свою внешнюю политику на основе международных норм. Таджикистан, руководствуясь высшими интересами народа, может входить в содружества и другие международные организации, а также выходить из них, устанавливать связи с зарубежными странами» [4].

Кроме того, Республики Таджикистан с 2003 года поддерживает политику "открытых дверей", что ещё усилила взаимодействия страны с зарубежными государствами и укрепила позитивный имидж государство на мировой арене.

Благодаря независимости и весьма мудрой политики Президента Республики Таджикистан уважаемого Эмомали Рахмона, наше государство сумела представить свою древнюю историю и национальную культуру на мировой арене. После завершения гражданской войны иподписания Соглашения об установлении мира и национального согласия Республики Таджикистан начала ознакомить древнюю историю и культуру таджиков мировому сообществу.

В этой связи, хотелось бы подчеркнуть, важные культурно-исторические мероприятия, проведенные Республикой Таджикистан, как и внутри страны, так и за её пределами. В частности:

$\checkmark$ Празднования 1100-летия государства Саманидов (сентябрь 1999г.,);

$\checkmark$ Международная научная конференция, посвященная 2700-летию книги «Авесто» (1-2 ноября 2001г.);

$\checkmark$ Празднования 2500-летия г. Истаравшана (10 сентября 2002г.));

$\checkmark$ Празднования 1000- летия поэта и великого таджикского мыслителя Носира Хусрава (сентябрь 2003 г.,);

$\checkmark$ Международная научная конференция «Ибн Сина и мировая цивилизация» посвященной 1025-летию Абу Али ибн Сины (6 сентября 2005 г.));

$\checkmark$ Празднования Года арийской цивилизации (8 сентября 2006 г.,);

$\checkmark$ Празднования 2700- летия г. Куляба (сентябрь 2006 г.,);

$\checkmark$ Празднования 800-летия Мавлоно Джалолиддин Балхи (сентябрь 2007г.,);

$\checkmark$ Международный научный симпозиум «Рудаки и мировая культура» посвященная 1150-летию основателя персидско-таджикской классической литературы Абуабдуллы Рудаки (сентябрь 2008г.,),

$\checkmark$ Международый симпозиум «Наследие Абу Ханифы и его значение в межцивилизационном диалоге», посвященный 1310-летию Имама Абу Ханифы (5 октября 2009г.,);

$\checkmark$ Международный праздник Навруз (25-26 марта 2012г..),

$\checkmark$ Празднования 600 - летия Абдурахмана Джами (октябрь 2014г.);

$\checkmark$ Празднования 700-летия Мир Сайид Али Хамадонй (сентябрь 2015г.,) ;

$\checkmark$ Празднования 3000-летия Гиссара (27 октябри соли 2015)[5,232];;

$\checkmark$ Международный научный симпозиум "Исследования древней культуры: вчера и сегодня" (21-23 октября 2019г.))[6,2].

Все эти мероприятия проводимой Республикой Таджикистан подчеркивает о значимой роли страны в представлении и ознакомлении своей культуры в укреплении дружеских отношений между государствами.

В условиях глобализации и информационно-коммуникационных технологий, познание своей культуры и истории, очень важны для каждого человека, особенно это касается молодого поколения. Так как, они в основном вовлечены в социальные сети 
интернет. Кроме того, террористические группировки, используя возможности современных информационных технологий, насаждают в сознание неопытной молодежи идеи исламского радикализма и агитируют их на убийства, нарушение безопасности и стабильности в различных странах.

В этой связи, Президент Республики Таджикистан уважаемый Эмомали Рахмон подчеркивал: «В условиях глобализации и развития информационных технологий, что приводит к засорению национальной культуры чуждыми элементами, обращение к истории, познание себя, очень важны и даже обязательны для каждого человека, в особенности подростков и молодежи» $[7,2]$.

Опыт стран мира показывает, что многие государства через национальную культуру и народных ремесел представили себя миру. В этой связи, Президент Республки Таджикистан уважаемый Эмомали Рахмон в своем ежегодном послании от 22 декабря 2017 года для развития народных ремесел и с целью развития туристической отрасли и представления национальной культуры таджиков в мире объявил 2018 год - «Годом развития туризма и народных ремесёл». Также, Глава государства в своем последующем послании от 26 декабря 2018 года для развития инфраструктуры туристической отрасли во всех регионах страны и с учетом необходимости развития сельской инфраструктуры, объявил 2019-2021 годы «Годами развития села, туризма и народных ремесел».

Хотелось бы подчеркнуть, что уже в течение первого года объявления «Годов развития села, туризма и народных ремесел» в сельской местности страны наблюдается ряд продвижений и обеспечивается развитие туризма и народных ремесел. За 9 месяцев текущего года более 1 миллиона туристов посетили заповедные места нашей страны, что на 20 процентов больше по сравнению с прошлым годом [7, 3].

Таджикистан сегодня реализует свою культурную дипломатию в рамках многосторонних инструментов. В частности, наше государства тесно сотрудничает с ЮНЕСКО-й (специализированное учреждение Организации Объединённых Наций по вопросам образования, науки и культуры). Таджикистан стал членом ЮНЕСКО 6 апреля 1993 года. В том же году было принято решение об учреждении Национальной комиссии Таджикистана по делам ЮНЕСКО при МИД-е Республики Таджикистан.

Достижения внешней политики Таджикистана в сотрудничестве с ЮНЕСКО:

- в 2002 году столица Таджикистана - город Душанбе, стал лауреатом премии ЮНЕСКО «Город мира»;

- в 2003 году классическая музыка Таджикистана и Узбекистана «Шашмаком» была введена в Список всемирного наследия ЮНЕСКО в качестве шедевра устного и нематериального наследия человечества;

- в 2010 году решением 34-й сессии Комитета всемирного наследия ЮНЕСКО одно из древнейших поселений на территории Таджикистана - Саразм был внесен в Список всемирного культурного наследия ЮНЕСКО;

- По инициативе Президента Республики Таджикистан и при поддержке десяток стран мира, в том числе стран ареала культуры Навруза, этот древний праздник по Резолюции Генеральной Ассамблеи ООН от 23- февраля 2010 года обрел международный статус;

- в 2013 году решением 36-й сессии Комитета всемирного наследия ЮНЕСКО Национальный парк Таджикистана - Горы Памира был включен в Список всемирного природного наследия ЮНЕСКО;

- в 2013 году в Париже в штаб-квартире ЮНЕСКО состоялась презентация книги «Архитектор мира», посвященной ценному вкладу Президента Таджикистана Эмомали Рахмона в установление прочного мира в стране.

- в 2013 году ЮНЕСКО наградила Президента Республики Таджикистан Эмомали Рахмона юбилейной медалью «60-летие ЮНЕСКО» за постоянную приверженность 
целям укрепления прочного мира, содействию устойчивому развитию, в частности посредством инициатив по развитию сотрудничества в водной сфере, международного диалога, обмена научными достижениями и ускоренной реализации Целей Развития Тысячелетия и других, согласованных на международном уровне целей развития.

- в 2013 году в Париже в ходе 37-й сессии Генеральной конференции ЮНЕСКО в Список юбилейных дат ЮНЕСКО на 2014-2015 годы были внесены празднования 3000-летия Гиссара, 700-летия Мир Саида Али Хамадони (в сотрудничестве с Исламской Республикой Иран) и 600-летия Абдурахмана Джами $[8,174]$.

- в 2018 чакан был включен в Список культурного материального человеческого наследия.

Республика Таджикистан продолжает развивать и представлять свою национальную культуру и историю на международной арене в сотрудничестве с ЮНЕСКО. Так, В 2019 году музыка Фалак, исторический памятник Хулбук, праздники Мехргон и Сада также были предложены в список всемирного культурного наследия ЮНЕСКО [9, 4]. Кроме того, по предложению нашего государства Генеральная конференция ЮНЕСКО приняла решение о праздновании 5500-летия древнего Саразма и 700-летия выдающегося таджикского поэта Камола Худжанди в 2020 году, что является одним из важнейших достижений культурной дипломатии Таджикистана.

В Таджикистане, с 1991 года функционирует Таджикское общество дружбы и культурной связи с зарубежными странами (ТОДКС), которое было создано по инициативе общественности Таджикской ССР 31октября 1958. Общество тесно сотрудничает с посольствами и международными организациями, аккредитованными в Таджикистане, расширяет связи и сотрудничество с родственными организациями дальнего и ближнего зарубежья, с национально-культурными центрами таджиков и с обществами дружбы таджикистанцев, созданных в других странах. Данное общество на сегодняшний день объединяет более 20 таких организаций, руководителями, которых выступают видные общественные, политические, научные деятели и деятели культуры. Кроме того, под эгидой ТОДКС действует Таджикская ассоциация породненных городов. Города Таджикистана, такие как Душанбе и Худжанд побратимы со многими городами мира. Города-побратимы обмениваются опытом городского самоуправления, ведения городского хозяйства, охраны окружающей среды, организации образования, досуга и т.д. [10, 347].

Традиционным стало двухсторонние культурные связи и проведение Дней культуры и других духовных ценностей Таджикистана с другими странами мира. Двухсторонние культурные отношения показывают насколько важным стали культурные связи между государствами.

Благодаря успешной и эффективной политике руководства Таджикистана, мировое сообщество доброжелательно и с доверием смотрит на нашу страну. Последовательные стремления Президента нашей страны уважаемого Эмомали Рахмона в представлении и ознакомлении мировому сообществу древнюю историю и культуру таджикского народа, укрепили позитивный имидж Таджикистана на международной арене, содействовали еще больше налаживанию хороших отношений Таджикистана с другими странами и внесли большой вклад в развитии других связей.

\section{Литературы:}

1. «Cultural Diplomacy in Central Asia and Eurasia. 16 -17 September, Dushanbe, Tajikistan». [электронныйресурс]. URL // https: //research.kent.ac.uk/gcrfcompass/wpcontent/uploads/sites/169/2019/11/TNU-Conference-Finalprogramme-12-September-v2.pdf

2. Выступление Лидера нации, Президента Республики Таджикистан на пленарном заседании Конференции высокого уровня «Международное и региональное сотрудничество в борьбе против терроризма и источников его финансирования, в том числе незаконного оборота 
наркотиков и организованной преступности» 17 мая 2019. // “Народная газета” № 22, (20200) 22 мая 2019 г, стр. 2

3. «Выступление Президента Республики Таджикистан по случаю первого празднования «Дня работников дипломатической службы» и открытия здания Главного консульского управления Министерства иностранных дел».[электронный ресурс]. URL:http://www.president.tj/ru/node/13251

4. Конституция Республики Таджикистан от 22 мая 2016 года. [электронный ресурс]. URL:https://mfa.ti/ru/main/tadzhikistan/konstitutsiya

5. Эмомалй Рахмон - бунёнгузори сиёсати хоричии Точикистон.(Зери назари Хамрохон Зарифй). - Душанбе. «Ирфон», 2012, 272 сах. Хайати таълиф: Х. Зарифй, Н. Зохидов, Д. Назриев, Х. Сафаров.

6. Симпозиуми байналмилалии илмии “Пажуухиш дар фарханги бостон: аз дирӯз то имрӯз" // “Минбари халқ” №43 (1232). 23 октябри соли 2019 сах. 2 -4

7. Послание Президента Республики Таджикистан Эмомали Рахмона Маджлиси Оли, 26 декабря 2019 года, город Душанбе. // “Народная газета” № 52, (20230) 30 декабри 2019 г, стр. 2-4

8. Дипломатия Таджикистана: вчера и сегодня. В двух томах. Том 1. (Под общей редакцией Хамрохона Зарифи)Серия:Внешняя политика Таджикистана.Душанбе:«Ирфон»,2009,296с.

9. Послание Президента Республики Таджикистан Маджлиси Оли Республики Таджикистан. 26 декабря 2018. // “Согдийская правда” № 104, (16710) 29- декабря 2018 г, стр.1-4.

10. Хошимов Ф. Дж. Народная дипломатия как важный фактор развития двухсторонних отношений России и Таджикистана /Ф. Хошимов // Стратегические ориентиры политики государств Центральной Евразии в условиях глобали-зации и регионализации: сборник научных статей. - Душанбе: РТСУ, 2019. -345-353.

\section{MUZEYLAR HUDUD TURIZMINING IJTIMOIY-MADANIY MARKAZI (RAMZI) SIFATIDA}

\section{Djurakulov Jamshid Avazovich Samarqand davlat muzey-qo'riqxonasi Turizm va marketing bo'limi boshlig'i E-mail: jamshidavazovich@gmail.com}

Annotation: The article is devoted to the museum as a part of social and cultural sector of modern city. The article discusses the current problems in the field of museums and the obstacles to their development, the creation of a positive image of the region and its transformation into a cultural center, the elimination of seasonality in tourism through the development of museums.
Key words : museum, marketing, service, communication, exhibition, social and cultural sector, tourism, visitors, administration.

O'zbekiston ko'p asrlik madaniy qadriyatlarga, milliy urf-odatlar va an'analarga, o'ziga xos hunarmandchilik maktablariga, ushbu tajribalar asosida yaratilgan san'at asarlari hamda tarixiy-madaniy me'moriy yodgorliklariga ega mamlakatdir. Bugungi kungacha yetib kelgan tarixiy ahamiyatga molik madaniy merosimizni ro'yxatga olish, ilmiy o'rganish, keng omma ayniqsa yosh avlodga o'z ona vatani tarixiga hurmat va muhabbat tuyg'ularini singdirish, ularni kelajak avlodga beshikast yetkazish maqsadlarini amalga oshirish muzey-qo'riqxonalarning bevosita vazifasi va faoliyatining asoslari hisoblanadi.

O’zbekiston Respublikasining 2008-yil 12-sentyabrdagi «Muzeylar to'g'risida»gi qonunida "muzey - muzey ashyolari va muzey kollektsiyalarini saqlash, o'rganish hamda ommaga namoyish etish uchun mulkdor tomonidan tashkil etilgan doimiy faoliyat yurituvchi notijorat madaniyat muassasasi", deb ta'rif berilgan.

Muzey jamiyatni o'z tarixi va madaniyatiga nisbatan bo'lgan munosabatini aks ettiruvchi ko'zgu hisoblanadi. Shuningdek, butunjahon muzeyshunoslikni XXI asr tajribasidan ma'lumki boy to'plamga va yerik tarixiy badiiy monumental inshootlarga ega muzeylar bugungi kunga 
kelib o'zlari joylashgan hudud brendiga aylanishga ulgurib bo'lishgan. Masalan, Londondagi Britaniya muzey (Buyuk britaniya), Nyu Yorkdagi Metropoliten san'at muzeyi (AQSH), Parijdagi Luvr muzeyi (Fransiya), Madriddagi Prado muzeyi (Ispaniya), Sankt-Peterburgdagi Davlat Ermitaji (Rossiya) kabilar o'zlari joylashgan shaharlarda ijtimoiy-iqtisodiy va madaniy hayotning ajralmas bo'lagiga aylanishib ulgurishgan. Ushbu muzeylar nafaqat butunjahon san'at asarlar ko'rgazma zallari bilan balki yuqori darajada tadbiq etilgan servis va qo'shimcha xizmat ko'rsatish turlari bilan, muzey atrofida o'ziga xos interfaol va sayyohlarni to'planib o'zaro fikr almashish, tanishish, o'zining ekskursiya davomida olgan taassurotlari bilan bo'lishish imkoniyatlarini yaratib berish bilan ham alohida e'tirofga loyiq.

2018 yilgi muzeylar indeksiga ko'ra, 2019 yilda dunyodagi eng ko'p tashrif buyurilgan muzeylar ro'yxati [F.A.R.11]

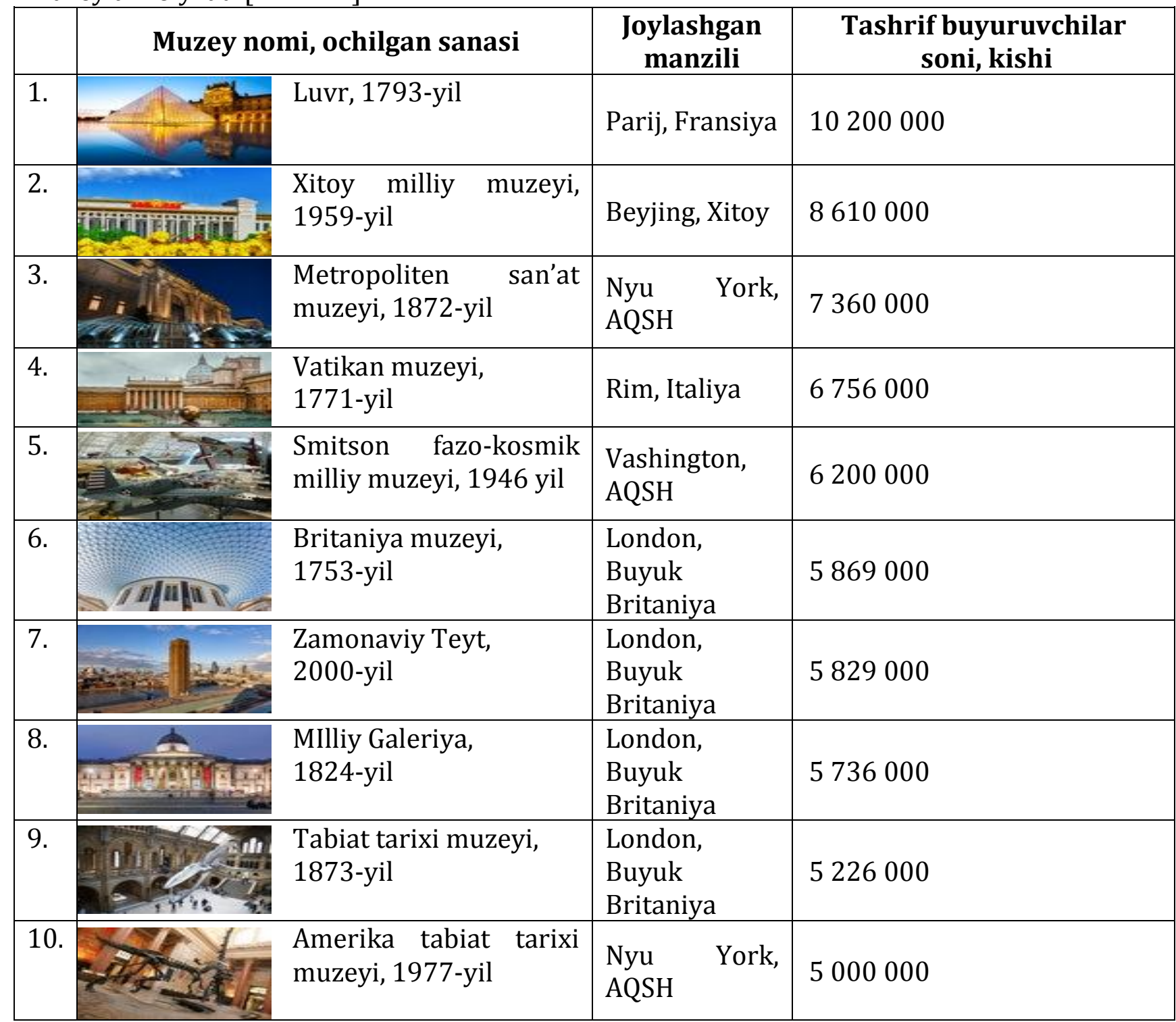

So'nggi yillarda O’zbekiston Respublikasida milliy madaniyatni yanada rivojlantirish, moddiy va nomoddiy madaniy meros durdonalarini saqlash va targ'ib etish, xalq og'zaki ijodiyoti va havaskorlik san'atini yanada ommalashtirish, yurtimizning jahon madaniy makoniga faol integratsiyalashuvini ta'minlash, madaniyat va san'at sohasini innovatsion rivojlantirishga qaratilgan tizimli chora-tadbirlar amalga oshirilib kelinmoqda.

O'zbekiston Respublikasi Davlat statistika qo'mitasi 2000-2017-yillarda O’zbekistondagi muzeylarning yillik statistikasi(yil oxiriga) [F.A.R.10] 


\begin{tabular}{|c|c|c|c|c|c|c|c|}
\hline & $2000 \mathrm{y}$. & $2012 \mathrm{y}$ & $2013 \mathrm{y}$ & $2014 \mathrm{y}$ & $2015 \mathrm{y}$. & $2016 \mathrm{y}$. & $2017 \mathrm{y}$. \\
\hline $\begin{array}{l}\text { Muzeylar soni } \\
\text { (filiallarni qo`shgan } \\
\text { xolda), birlik }\end{array}$ & 88 & 107 & 106 & 108 & 106 & 109 & 121 \\
\hline $\begin{array}{c}\text { Muzeylarning } \\
\text { eksponatlari soni, ming } \\
\text { birlik }\end{array}$ & 1669390 & 2013593 & 2072468 & 2167,4 & 2159,7 & 2060,7 & 2116,5 \\
\hline $\begin{array}{l}\text { Muzeylarda o`tkazilgan } \\
\text { ekskursiyalar soni, } \\
\text { birlik }\end{array}$ & 59334 & 71097 & 96565 & 103378 & 96793 & 107144 & 134147 \\
\hline $\begin{array}{l}\text { Muzeylarda tashkil } \\
\text { etilgan ko`rgazmalar } \\
\text { soni, birlik }\end{array}$ & 484 & 2214 & 2093 & 1548 & 1654 & 2307 & 1533 \\
\hline $\begin{array}{l}\text { Muzeylarga tashriflar } \\
\text { soni, ming }\end{array}$ & 3463.6 & 4847.0 & 5022,1 & 6016,9 & 5462,3 & 5371,2 & 6302,1 \\
\hline
\end{tabular}

Yuqoridagi jadvallarda keltirilgan statistik ma'lumotlar bizga insonlarni muzeylarga bo'Igan qiziqishlarini qanchalik darajada yildan-yilga oshayotganligini ko'rsatib turibdi. Bu o'zo'zidan muzey infratuzulmasi va xodimlarining xizmat ko'rsatish darajasi yuqori sifatda bo'lishligini talab etadi. Har bir turist muzeyga tashrif buyurar ekan u to kirib kelib, ko'rgazmadan estitek zavq olib, muzeydan chiqib ketgunicha yuqori darajali servis va xizmat ko'rsatishdan bahra olish imkoniga ega bo'lishi muzeyning keyingi istiqbolli faoliyat yuritishida muhim omil bo'lib xizmat qiladi. Tashrif buyuruvchiga manzur bo'ladigan servisni taqdim etish uchun klassik muzey faoliyatidan voz kechib, bozor iqtisodiyotiga mos yangicha yondashuv bilan muzeydagi faoliyatni nazorat qilish, servis va xizmat ko'rsatish sifatini tahlil qilish, zamonaviy texnologiyalarni jalb etish, muzeyning keyingi faoliyatini strategik rejalashtirish maqsadga muvofiq hisoblanadi. Albatta, bunda o'tgan asrlarning 70-yillarining so'ngida[F.A.R.8] muzeyshunoslikka kirib kelgan "muzey marketingi" muhim rol kasb etadi.

Muzey marketingi muzeyni targ'ibot va ommalshtirishning zamonaviy uslublari bilan unga tashrif buyuruvchilar auditoriyasini kengaytirish, hali muzey haqida ma'lumotga ega bo'Imagan hududlarni qiziqishini uyg'otish va muzeyning brendini o'zi joylashgan hududning madaniy-ijtimoiy ramziga aylantirishda asosiy muruvvat vazifani bajaradi.

Filip Kotlerning so'zlariga ko'ra, muzey mahsulotlari va xizmatlari boshqa joydan topish qiyin bo'lgan tajriba va taassurotlarni qamrab oladi [F.A.R.9]. Ushbu tajribalarni beshta asosiy elementdan tashkil topgan tegishli kontekstsiz yaratib bo'lmaydi:

- muzeyning o'zi (bino, zal, ichki makon);

- ob'ektlar (to'plamlar, ko'rgazmalar);

- interpret izohlash uchun materiallar (plitalar, yorliqlar, ma'lumot taxtalari, kataloglar);

- qo'llanmalar;

- ekskursiyalar va dasturlar (ma'ruzalar, tanlovlar, festivallar);

- xizmatlar (kafelar, dam olish maskanlari).

Ushbu elementlar muzeyga o'ziga xoslik bag'ishlaydi, brendni shakllantiradi va jamoatchilikni o'ziga jalb qiladi.

Bu borada hukumatimiz tomonidan jahon hamjamiyatida O'zbekiston Respublikasining ijobiy imidjini shakllantirish va mustahkamlash, muzeylarga yangicha yondashish, Respublikasidagi muzeylarni rivojlantirishning innovatsion va amaliy mexanizmini ishlab chiqish, ko'rsatilayotgan xizmatlar sifatini oshirish, infratuzilmani yaxshilash, san'at va badiiy ijodni rivojlantirish uchun zarur shart-sharoitlar yaratish, respublikaning muzey to'plamlaridagi boy tarixiy va madaniy merosini keng targ'ib qilish va ommalashtirish maqsadlarini amalga oshirish yo'lida O'zbekiston Respublikasi Prezidentining 2018-yil 26- 
avgustda“O'zbekiston Respublikasida madaniyat va san’at sohasini innovatsion rivojlantirish chora-tadbirlari to'g'risida" PQ-3920-son qarori, O'zbekiston Respublikasi Vazirlar Mahkamasining 2019-yil 19-dekabrda “2020-2021-yillarda O‘zbekiston Respublikasida muzeylar faoliyatini takomillashtirish dasturini tasdiqlash to'g'risida" 1019-son qarori, O‘zbekiston Respublikasi Vazirlar Mahkamasining 2020-yil 23-mayda "O'zbekiston Respublikasida muzey va teatrlarning marketing faoliyati samaradorligini oshirish to'g'risida" 325-son qarori, 0‘zbekiston Respublikasi Prezidentining 2020-yil 26-may "Madaniyat va san'at sohasining jamiyat hayotidagi o'rni va ta'sirini yanada oshirish chora-tadbirlari to'g'risida" PF6000-son farmoni qabul qilinib, bugungi kunda barcha muzeylar faoliyatiga keng tadbiq etib kelinmoqda.

O'zbekiston Respublikasi Prezidentining 2020-yil 26-maydagi "Madaniyat va san'at sohasining jamiyat hayotidagi o'rni va ta'sirini yanada oshirish chora-tadbirlari to'g'risida" PF6000-son farmoni ayni muzey sohasi vakillari uchun ko'p yillar davomida to'planib qolgan muommolarning yechimi bo'ldi desak so'zimiz mubolag'a bo'lmaydi. Chunki, muzeylar notijorat madaniyat muassasi bo'laganligi sababli muzeyga zamonaviy servis va qo'shimcha xizmat ko'rsatish, qo'shimcha daromad topish, muzey ashyolarini xalqaro ko'rgazmalarda namoyish etish kabi muhim faoliyatlarni amalga oshrishda bir qancha ma'lum to'siqlar mavjud edi. Yangi e'lon qilingan farmon yordamida esa:

- muzeylarning daromad manbalarini kengaytirish maqsadida ular tomonidan tadbirkorlik faoliyatini amalga oshirish, jumladan tovarlar sotish va xizmatlar ko'rsatishning huquqiy asoslarini belgilashga qaratilgan qonun loyihasini ishlab chiqish;

- Milliy muzey fondini raqamlashtirish bo'yicha chora-tadbirlarni amalga oshirish;

- "Buxoro", "Samarqand", "Ichan qal'a”, "Sarmishsoy", "Shahrisabz", "Termiz" va "Qo'qon" davlat muzey-qo'riqxonalari hududlarining chegarasini belgilash ishlarini yakunlash;

- Madaniy boyliklarni O'zbekiston Respublikasi hududidan olib chiqish va uning hududiga olib kirish tartibini, shu jumladan ushbu sohadagi ruxsat beruvchi hujjatlarni va ularni rasmiylashtirish jarayonlarini soddalashtirish, yakka tartibdagi tadbirkorlarga madaniy boyliklarni realizatsiya qilish faoliyati bilan shug'ullanish huquqini berish;

- O’zbekiston madaniy merosini asrash, o'rganish va ommalashtirish bo'yicha butunjahon jamiyati faoliyatini qo'llab-quvvatlash;

- Aholining keng qatlami, shuningdek, o'quvchi-yoshlar orasida davlat muzeylarida saqlanayotgan milliy moddiy madaniy meros boyliklari, jumladan arxeologik, amaliy san'at, numizmatika, litografik kabi eksponatlarning foto va ko'chma ko'rgazmalari haqida targ'ibot tadbirlarini tashkil etish;

- O‘zbekiston muzey eksponatlari ishtirokida 2021-2022-yillarda Parij shahridagi Arab dunyosi instituti (Fransiya), Pekin shahridagi Pekin milliy muzeyi (Xitoy) va Samarqand shahrida ShHT davlat rahbarlari sammiti doirasida "Ipak yo'li" ko'rgazmasini tashkil etish va o'tkazish kabi faoliyatlarning jonlanishi muzey sohasi uchun ayni muddao bo'ldi.

Shuningdek, O'zbekiston Respublikasi Vazirlar Mahkamasining 2020-yil 23-mayda "O'zbekiston Respublikasida muzey va teatrlarning marketing faoliyati samaradorligini oshirish to'g'risida" 325-son qarorida muzeylarga tutash hududlarda interfaol zonalarni yaratish, muzeylarda xorijiy tillarni mukammal biladigan gid (gid-tarjimon), muzey brendini targ'ib qilish bo'yicha marketolog va uning xizmatlarini monetizatsiya qilish bo'yicha mutaxassis lavozimlarini joriy qilish, tashrif buyuruvchilar va turizm sohasining subyektlari orasida so'rovnoma olib borish, marketing tadqiqotlari va jamoatchilik bilan o'zaro aloqa qilishning strategiyasini avtomatlashtirishga moljallangan keng qamrovli axborot tizimi va ma'lumotlar bazasini (CRM) muzeylar faoliyatida joriy etish, zamon talablariga javob beradigan muzeylar infratuzilmasini rivojlantirish va qiyofasini o'zgartirish maqsadida dunyoning yetakchi muzeylaridan xorijiy mutaxassislarni jalb qilish;muzey ichida hunarmandlar ustaxonasini va savdo shoxobchalarini tashkil etish hamda ularda muzey ashyolari va kolleksiyalari nusxalari milliy suvenir mahsulotlari savdosini yo'lga qo'yish;muzeyda axborot 
va virtual haqiqat texnologiyalardan foydalangan holda sensorli ekranlarda interfaol ko'rgazmalar o'tkazish;muzeylar ichida fotosurat va videotasvirga olish tartibini soddalashtirish, muzeylarning turizm sohasidagi ishtirok etishi yuzasidan baholash reytingini olib borish, muzey ashyolarini chet el ko'rgazmalariga vaqtincha olib chiqilganda ularning butligini saqlashga qaratilgan sug'urta qilish taomillarini ishlab chiqish kabi muzeyshunoslarga keng ommaviy vazifalar va istiqbolli chora-tadbirlar amalga oshirish belgilangan.

Bugungi kunda Samarqand davlat muzey-qo'riqxonasi tarkibida 9 ta muzey va 7 tarixiy madaniy meros mavjud, shundan Samarqand shahrida O'zbekiston madaniyati tarixi davlat muzeyi, Samarqand shahar tarixi Afrosiyob muzeyi, Mirzo Ulug'bek rasadxonasi muzey majmuasi, Samarqand viloyat o'lkashunoslik muzeyi, Sadriddin Ayniy uy-muzeyi kabi o'zining noyob va nodir ashyolari bilan boyitilgan ko'rgazma zallari bilan mahalliy va xorijiy sayyohlarga xizmat ko'rsatib kelmoqda. Hukumatimiz tomonidan qabul qilingan istiqbolli hujjatlarga hamohang tarzda Samarqand davlat muzey-qo'riqxonasida ham istiqbolli reja asosida bir qator vazifalarni belgilab olgan holda faoliyat yuritib kelmoqda. Vazirlar mahkamasining 2017-yil 11-dekabrdagi "2017 - 2027-yillarda davlat muzeylari faoliyatini yanada takomillashtirish va moddiy texnik bazasini mustahkamlash bo'yicha kompleks choratadbirlar dasturini tasdiqlash to'grisida" 975-sonli qaroriga asosan 2019-2022-yillarda Samarqand davlat muzey-qo'riqxonasining O'zbekiston madaniyati tarixi davlat muzeyiga yangi zamonaviy bino qurilishi dasturga kiritilgan. Bugungi kunda, muzey-qo'riqxonaning samarkandmuseum.uz rasmiy sayti va facebook, telegram, youtubeda rasmiy sahifalarida jami o'rtacha har bir nashrga 63 ming kishi qamrovida doimiy kuzatib borilmoqda. "Virtual muzey" loyihasi asosida Afrosiyob muzeyi va Mirzo Ulug'bek muzey-majmuasiga 3D formatdagi ko'rinishlar ishga tushurilgan. Samarqanddagi Amir Temur maqbarasi, Bibixonim majmuasi, Mirzo Ulug'bek muzey-majmuasi, O'lkashunoslik muzey, Afrosiyob muzeyi, Ergash Jumanbulbul o'g'li uy-muzeyi, Sadriddin ayniy uy-muzeyida "Smart-muzey" tashkil etilgan. Shuningdek, turistlar oqimini hisobga olgan holda Afrosiyob muzeyida S0OLAI TG-20T markali 40 dona audiogid vositalari joriy etilgan.

Muzey nafaqat sayyohlar uchun estetik va madaniy hordiq olish maskani bo'lib xizmat qiladi, balki undan tashqari bir qator ijtimoiy-madaniy omillarni shakllanishida muhim rol kasb etadi:

- muzeylar hudud tarixiga oid joriy va ushbu davrgacha bo'lgan badiiy tarixiy qiymatga ega bo'lgan san'at asarlarini to'playdi va saqlaydi;

- to'plangan san'at asarlarini ilmiy tadqiqot qiladi va keng ommaga uning mazmun mohiyatini ochib beradi, targ'ibot ishlarini amalga oshiradi;

- katta hayotga qadam qo'yayotgan, o'zining kelajak maqsadlarini belgilab olayotgan yosh avlodni haqqoniy tarixiga bo'lgan fikrlarini va ona vatanga bo'lgan muhabbatni shakllantirishda vaqt mashinasidek xizmat qiladi;

- mahalliy va xorijiy sayyohlarga tarixiy obidalarga ekskursiya orqali to'planib qolgan savollar va noaniqliklarga ko'rgazma zallaridagi tarixiy davriyligi bilan joylashtirilgan ashyolar yordamida aniqlik kiritadi;

- muzeylardagi qo'shimcha xizmatlar va uning atrofidagi interfaol muhit hududdagi turizmning "mavsumiylik" kamayishiga olib keladi.

Xulosa o'rnida shuni aytish mumkinki, faoliyati to'gri tartibga qo'yilgan muzey o'zi joylashgan hududining nafaqat ijtimoiy-madaniy markazi sifatida shaharning brendiga ramziga aylanishi, balki iqtisodiy daromad keltiruvchi tashkilotlar qatorida salmoqli ulushni kasb etishi mumkin. Ushbu maqsadlarni amalga oshirishda, muzeyning joylashgan manzili haqida shaharning sayyohlar ser qatnov joylarida (aeraport, temiryo'l vokzali, xiyobonlar, markaziy ko'chalar, tarixiy obidalar, aholi dam olish ko'ngil ochar tashkilotlari, mehmonxonalar) o'zbek, ingliz va rus tillarida muzey haqidagi ma'lumot beruvchi yo'l ko'rsatkich belgilar, plakatlar, elektron tablo va kiosklar, tarqatma materiallar (buklet, fleyer, katalog) bilan taminlanganligi maqsadga muvofiq hisoblanadi. Shuningdek, muzey rasmiy saytining ko'p tilda ma'lumot bilan 
boyitilganligi, uning keng jamoatchilik foydalanadigan ijtimoiy tarmoqlarda rasmiy sahifa va bloglarining mavjudligi, ularning aholini barcha qatlamiga ma'lumot olishining qulayligi va ochiqligi muhim hisoblanadi.

\section{Adabiyotlar :}

1. O'zbekiston Respublikasi «Muzeylar to'g'risida»gi qonuni. 2008-yil 12-sentyabr.

2. O'zbekiston Respublikasi Prezidentining “O'zbekiston Respublikasida madaniyat va san'at sohasini innovatsion rivojlantirish chora-tadbirlari to'g'risida”gi 2018-yil 26-avgustdagi PQ-3920-son Qarori.

3. O'zbekiston Respublikasi Prezidentining "Madaniyat va san'at sohasining jamiyat hayotidagi o'rni va ta'sirini yanada oshirish chora-tadbirlari to'g'risida"gi 2020-yil 26-maydagi PF-6000-son Farmoni.

4. O'zbekiston Respublikasi Vazirlar mahkamasining “2017 - 2027-yillarda davlat muzeylari faoliyatini yanada takomillashtirish va moddiy texnik bazasini mustahkamlash bo'yicha kompleks chora-tadbirlar dasturini tasdiqlash to'grisida"gi 2017-yil 11-dekabrdagi 975-sonli Qarori.

5. O'zbekiston Respublikasi Vazirlar mahkamasining "2020-2021-yillarda O'zbekiston Respublikasida muzeylar faoliyatini takomillashtirish dasturini tasdiqlash to'g'risida"gi 2019-yil 19-dekabrdagi 1019-son Qarori.

6. O'zbekiston Respublikasi Vazirlar Mahkamasining “O'zbekiston Respublikasida muzey va teatrlarning marketing faoliyati samaradorligini oshirish to'g'risida"gi 2020-yil 23-maydagi 325son Qarori.

7. Ismailova J., Nishanova K., Muhamedova M. Muzey va Jamiyat.-Toshkent, "FOLIANT-PRINT”, 2015.

8. И.А.Шашерина, У.В.Шиянова, Музейный маркетинг и виртуальные музеи в XXI веке: могут ли музеи выжить без этого?, Молодой ученый.-2019.-№24.-С401

9. Kotler N.\& Kotler P., Museum Marketing and strategy: Designning Missions, Building Audiencesm, Generating Revenue and Resources [Text.] - San Francisco: Jossey-Bass Publishers, 2008.

10. https://www.stat.uz(O'zbekiston Respublikasi Davlat statistika qo'mitasi).

\section{TURIZM SANOATIDA INGLIZ TILINING O'RNI}

\section{Normetova Odila Ruzmatovna Xorazm viloyati Shovot tumani 14 -maktab o'qituvchisi}

Annotation: $\quad$ This article is about the importance of English language in tourism.English language plays an important role in tourism industry, so there is an assential need for tour guides and entrepreneurs. Uzbek tourism organization made a special educational system to teach new staffs.
Key words :

museum, marketing, service, communication, exhibition, social and cultural sector, tourism, visitors, administration.

Shiddat bilan rivojlanayotgan hozirgi zamonda turizm dunyo sanoatining yetakchi tarmog'iga aylanib bormoqda.Dunyoning rivojlangan mamlakatlari Fransiya, Buyuk Britaniya, Italiya , Ispaniya kabi tarixiy va zamonaviy inshootlarga boy bo'lgan davlatlar aynan shu sohada katta daromadga erishmoqdalar. Statistik ma'lumotlarga ko'ra turizm butun dunyo yalpi ichki mahsulotining 10\% ini tashkil qiladi. Dunyo bo'yicha 300 millionga yaqin kishi shu sohada faoliyat yuritmoqda.(1)

O'zbekistonda ham xalqaro turizm sohasi rivojiga katta e'tibor qaratilmoqda. Turizm sohasida yetarlicha inkoniyatga ega bo'lgan yurtimiz butun dunyodaga o'z eshiklarini ochmoqda.O'zbekiston Respublikasi Prezidentining 2019 -yil 5-yanvardagi PF - 5611- sonli Farmoniga ko'ra, 2019 -2025 yillarda turizm sohasini rivojlantirish maqsadlari, turizmni milliy iqtisodiyotning strategik tarmog'iga aylantirish, turistik infratuzilmani rivojlantirish va xorijiy sarmoyalarni jalb qilish bo'yicha konsepsiya ishlab chiqildi.

Turizm sohasining asosi bu albatta xorijiy tillardir. Chunki til bu insonlar, turli millatlar va xalqlarni bir- biri bilan bog'laydigan ko'prikdir. Shu o'rinda ingliz tilining o'rni va ahamiyati beqiyos. Butun dunyoda 2 milliardga yaqin kishi ingliz tilida so'zlashmoqda. Yurtimizda ingliz 
tilini o'rgatish va o'rganishga juda katta e'tibor berilmoqda. Prezident qarori bilan 2013- 2014 o'quv yilidan boshlab chet tillarini, xususan, ingliz tilini maktablarda boshlang'ich sinflardanoq o'qitish yo'lga qo'yildi. Bundan tashqari Britaniya kengashi O'zbekiston Respublikasi O'rta maxsus kasb ta'limi bilan hamkorlikda " Ingliz tili turizm uchun" deb deb nomlangan loyihani amalga oshira boshladi. Bu kurs tinglash, so'zlashish va yozish ko'nikmalariga qaratilgan bo'lib, shu jumladan jamoa bo'lib ishlash, aloqa vositalari va elektron pochtadan foydalanish ko'nikmalarini rivojlantirishga oid materiallarni o'zida mujassam etadi. Bu loyiha 2014 yil fevral oyida sinovdan o'tkazildi.

Sayyohlar oqimining qariyb 70\% i ingliz tilida muloqot qilishlarini inobatga olsak, ingliz tilining bugungi kunda naqadar dolzarb ekanligiga guvoh bo'lamiz.Shu maqsadda O'zbekturizm Qo'mitasi ingliz tilidan yuqori salohiyatli gid tarjimonlarni tayyorlash bo'yicha dasturlar ishlab chiqmoqda. Turistik hududlarda faoliyat olib boruvchi tadbirkor va hunarmandlar , xavfsizlik xodimlari ham ingliz tilida erkin muloqot qila olishadi. Turizm rivojlanishidagi yana bir qadam, " Ipak yo'li" turizm xalqaro universitetini tashkil etilishi haqidagi O'zbekiston Respublikasi Prezidentining 2018 - yil 28 -iyundagi qarori bo'ldi. Ushbu qaror 27 banddan iborat bo'lib, unda turizm sohasida chet tillarini mukammal biladigan professional kadrlarni tayyorlash tizimini tayyorlash va modernizatsiya qilishga qaratilgan yangi ta'lim dasturlarini hamda o'qitishning innovatsion shakllarini ishlab chiqish va joriy etish ko'zda tutilgan.

Internet manbalar:

1. http:// alison. com>learning path> tourism with english language

2. www.lex.uz

3. www.ziyonet.uz

\title{
UZBEKISTAN CULTURE AND TRADITIONS
}

\section{Sulaymanova Gulnaz Janabaevna 46 IDUM Teacher, Nukus city, Republic of Karakalpakstan E-mail: gulnaz1983j@mail.ru}

\begin{abstract}
Annotation:
The article describes Uzbekistan culture and traditions which are famous all over the world. These traditions and customs are associated with sport, music, food and many other occasions, such as tea ceremony, beshik-tuy, hanta-kilish, and weddings (fatiha tuy).Such happy moments of life as the birth and upbringing of children, matchmaking and wedding are attended by uncommon lively ancient rituals, in which all relatives, neighbors and guests are involved.
\end{abstract}

Key words: to communicate with, noteworthy ceremonies, negotiation, hospitality, associate with, wooden cradle, espousal agreement.

Uzbekistan cultures and traditions set by ancestors are carefully cherished and most secrets of fine art and crafts are inherited by generations. They are sacredly followed, with Oriental swing and sincere not talking about national, religious and family holidays. Traditional events such family ceremonies as child birth, circumcision and others are held to respect customs and rituals like horseracing as a common custom to be respected in older regions of Uzbekistan rather than in cities. Races involving goats and rooster are also one of national entertainments.

Bazaar. Eastern Bazaar is something that grasps all emotions when you are there to immerse in the world of authentic odorant atmosphere as unchanged. Bazaar is not only the place to trade; this is rather the place to communicate with friends and neighbors to exchange news and discuss issues. Bazaar negotiation is not only the item price discussion but also the special communication tool. Flashy colors and bazaar atmosphere make the special environment to attract all tourists there as one of the special places to attend along with other sightseeing. 

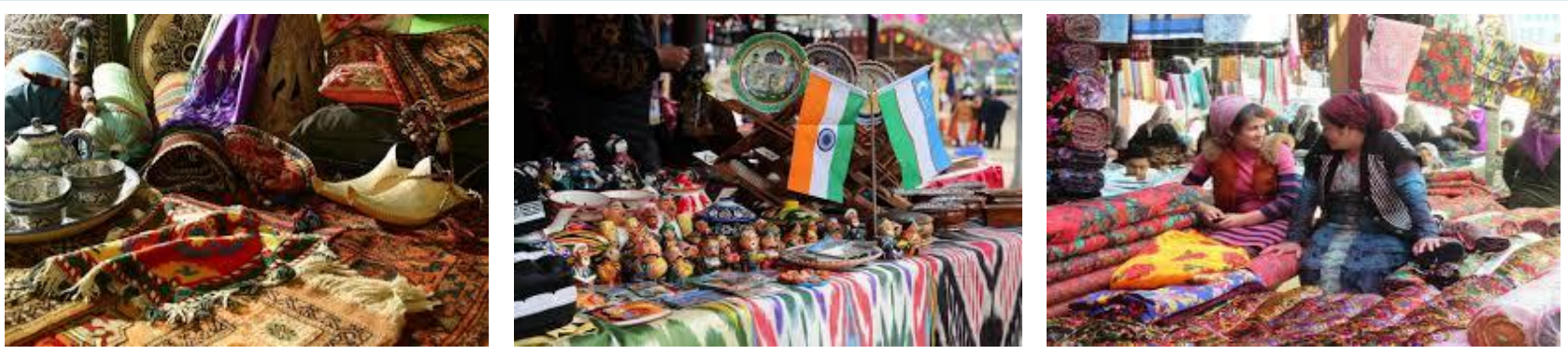

Tea ceremony. This is one of the most noteworthy ceremonies in Uzbek tradition with the tea made and poured by the host. Male guests and hosts shake hands while women and children are just greeted by the head nodding and putting the hand to the heart side as the respect gesture.
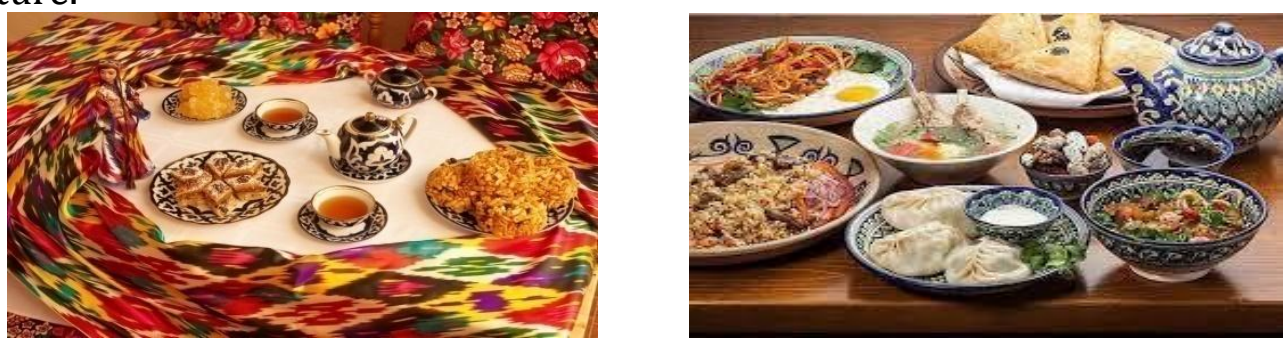

Shoes are put off when entering houses and guests take places shown at by the house owner. The farer the place, the more respectful it is. Uzbek people are globally recognized for hospitality and welcoming. Concernment to guests as well as esteem for older people (aksakal) is one of customs to be worth noting.

Customs. Uzbek customs are formed by centuries to be exclusive and most customs accompany family life specially associated with child birth and upbringing (beshik-tuy, hantakilish), weddings (fatiha tuy) and funerals. This is the mixture of Islamic ritualism metamorphosed with the time. For instance, Friday is the holy day marked with general pray (namaz).
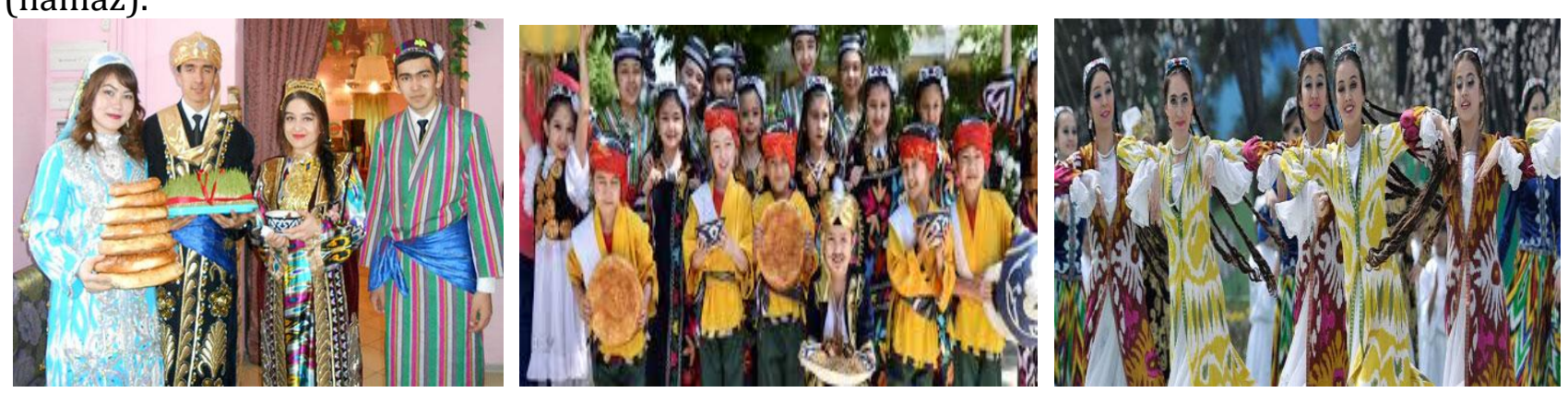

Beshik tuy (Wooden cradle). This is a ritual associated with the first laying of an infant into the cradle to be on 7th, 9th or 11th day from birthday. This is celebrated publicly. Guests enjoy the meal, music and dances and at the end guests come to look at the baby in the cradle and leave gifts.
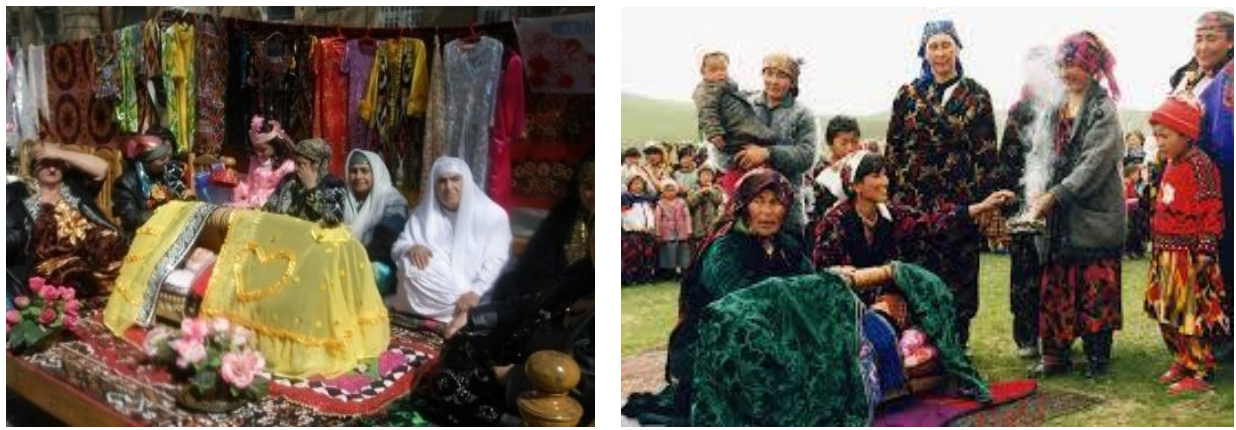

Fatiha tuy (engagement). Marriage ceremony is performed with parents' blessing. The wife-to-be is looked at by future husband's relatives and matchmakers go to her place to negotiate. Espousal date is set by them if the agreement is achieved. The most interesting thing 
is that the bread is broken (non sindirish) in the end of negotiations symbolizes conclusion and espousal agreement.
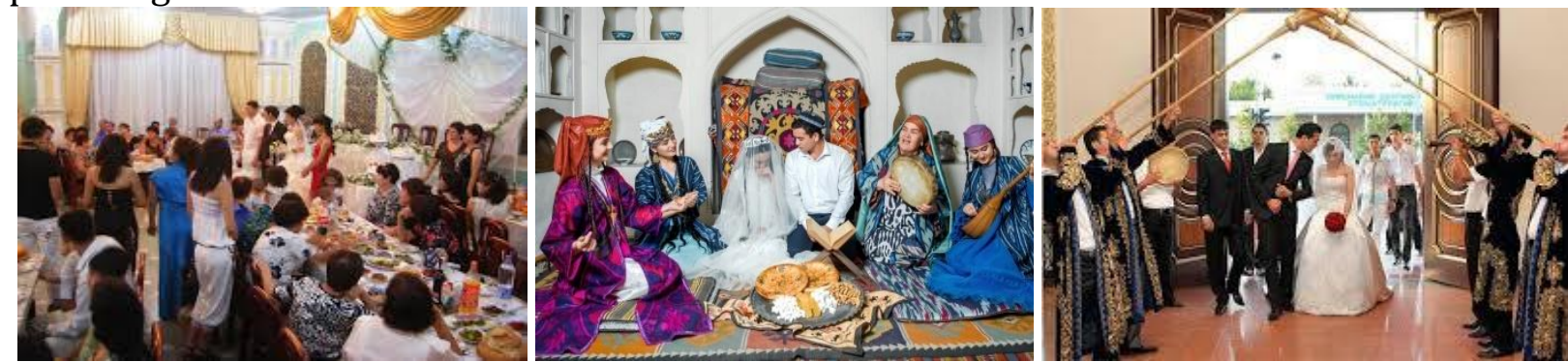

The custom is accompanied with presents and gifts from the girl's side to the husband-to be family. Several days before the wedding party the girls arranges hen party (kiz oshi). Dances, fine art and handicraft are also priorities in Uzbekistan. Glow, unique linear and color rhythm, eastern poetics make works of handicraftsmen original and exceptional.

\section{References:}

1. Adams, Laura L. "What Is Culture? Schemas and Spectacles in Uzbekistan." Anthropology of East Europe Review 16 (2): 65-71, 1998.

2. Nazarov, Bakhtiyar A., and Denis Sinor. Essays on Uzbek History, Culture, and Language, 1993.

3. Kalter, Johannes, and Margareta Pavaloi. Uzbekistan: Heirs to the Silk Road, 1997.

4. www.centralasiacultures.com

5. www.everyculture.com

\section{МАДАНИЯТ ВА ТИЛНИНГ ЎЗАРО МУНОСАБАТИ МАСАЛАЛАРИ}

\section{Суюнов Шерзод СамДчТИ ўқитувчиси E-mail: sh.suyunov89@gmail.com}

Annotation: This article analyzes the issues of the relationship between culture and language. The formation of man himself is directly related to culture. Because its activity is influenced by a certain nationalcultural, environmental. All aspects of human activity are reflected in the national culture. In addition, cultural procedures may have some control over human activities.
Key words :

culture, language, humanity, connection, society, human activity, nation, national traditions.

Тил билиш ва ташқи оламни ўзлаштиришнинг асосий воситаси сифатида бошқа маданиятлар билан танишиш учун катта имконият яратади. Миллий маданиятлардан ажратиб бўлмайдиган тиллар хам улар қаторида тақдирнинг худди шундай перипети орқали ўтадилар. Ғарбий Европа тарихида учунчи ўринда турган француз тили халқаро мулоқотнинг универсал тилига айланди. Бунгача бундай мақомга фақат грек ва лотин тиллари эга бўлган. Тахминан X асрга келиб француз тили ўзининг ахамияти бўйча лотин тили билан тенглаша бошлади. XVIII асрдан бошлаб француз тили ва шу билан бирга маданияти бутун дунё бўйлаб тарқала бошлади. Европа, Америка ва Россиянинг барча маърифатли қатлами француз тилида гапира ва ёза бошлади. Итальян дипломати Карачиоли томонидан муомалага киритилган “Француз Европаси” ибораси тезда хамма томонидан эътироф этила бошланди. 1889-1914 йиллар француз маданиятининг хамма мамлакатлар ва континентларга тарқалиши(экспанциясияси)нинг олтин даври хисобланади. Шу даврда Париж дунё санъатининг марказига айланади. Аммо XX асрга келиб француз тилидан омад юз ўгирди. Аллақачон, 1918 йилга келиб Версаль шартномасини имзолаш чоғида француз тили халқаро дипломатиянинг ягона тили хукмронлигидан махрум бўлди. Бундан хам кўра кўпроқ Иккинчи жахон уришининг натижалари Франция учун жиддий йўқотишларга олиб келди. 
$\mathrm{XX}$ асрнинг 50-йиллари охирларида колониал тизимнинг емирилиш жараёни вазиятни чукурлаштирди, чунки кўпгина собиқ колониялар француз тилидан воз кечдилар. Агар олдинги замонларда қарам ва қолоқ хисобланган мамлакатларда тилларнинг яшаб қолиши муаммоси кўндаланг турган бўлса, эндиликда бу хамма Европа мамлакатларига дахлдор бўлмоқда. Бу инглиз (Америка тили) тилининг кенг тарқалиши билан характерланади. Француз тили ўзининг имтиёзли ўрнини инглиз тили(Америка тили)га бўшатди. Чунки бу тил хозирги даврда мулоқотнинг универсал воситасига айланиб бормоқда. Шу сабабли аралаш, гибрид тиллар шаклланмоқда. Бунга мисол қилиб, француз ва инглиз тиллари қоришмаси асосида вужудга келган “франгле”, “френглиш" тушунчаларини келтириш мумкин. Айнан шундай шароитларда франкофония вужудга келди. Хозирги вақтда у 50 дан ортиқ мамлакатни қамраб олган ва хамма континетларда тарафдорлари бор. Гарчанд унинг мақсади француз тили ва маданиятини химоя қилиш, сақлаш ва гуллаб-яшнатиш бўлса-да, аммо илгариги устуворликни тиклашга даъвогарлик қилмайди. Франкофония хамма тиллар ва маданиятларни сақлаш ва ривожлантиришни назарда тутади, уларнинг ёнма-ён яшаши ва ўзаро бир-бирини бойитиши зарурлигини эътироф этади.

В.Гумбольдт турли миллат ва маданият вакилларининг воқелик хақида тасаввури мос келмаслигини исботламоқчи бўлади. Бу олимнинг таъкидлашича «Турли тиллар ягона бир предметни турлича номланиши бўлишидан кўра, ушбу предметни турлича кўриш, идрок этишдир» [3, 9].

Лисоний тафаккурнинг турли маданий-тарихий шароитларда ривожланишини махсус ўрганган эстон психологи П.Тульвесте ўз устози А.Р.Лурия таклиф қилган услуб асосида ўтказган қатор тажриба-синов тадқиқотлари натижаларига таянган холда «турли тилларга турли хилдаги билиш жараёни мос келади» деган фикрни бутунлай инкор қилади. Унинг фикрича, лисоний нисбийлик эмас, балки «фаолиятлар нисбийлиги» тўғрисида гапирган маъқулроқдир. Зеро, турли миллатлар тафаккур харакатларидаги фарқ «тиллараро фарқдан кўра кўпроқ у ёки бу маданиятда тарқалган фаолият турлари ўртасидаги фарқ ва болаларни ушбу фаолият турларини бажаришга ўргатиш усуллари билан боғлиқдир» $[9,49]$. Инсоннинг шаклланишининг ўзи бевосита маданият билан боғлиқдир. Чунки унинг фаолияти маълум миллий-маданият, мухит таъсирида бўлади. Инсон фаолият қирраларининг барчаси миллий маданиятда ўз аксини топади. Бундан ташқари маданият тартиб-қоидалари инсон фаолиятини муайян даражада назорат қилиб туриши мумкин. Хар қандай маданият атроф-мухит таъсирида тараққий қилиб, ўзгариб боради. Турли миллатлар маданияти бир-биридан дастлабки ўринда воқеликни моддий ва маънавий ўзлаштиришдаги фарқи жихатидан ажралиб туради. Бундай фарқнинг асосида ўзлаштирилаётган объект ёки бу фаолият махсули эмас, балки ушбу моддий-маънавий ўзлаштириш жараёни қандай ёки қай услубда кечаётганлиги ётади. Маданият қотиб қолган ходиса эмас, у мунтазам тараққий қилиб боради, бир холатдан иккинчисига ўтади, бошқа маданиятлар билан қоришиб кетиши хам мумкин. Инсоннинг маданиятли бўлиши ижтимоий тузум билан боғлиқ, бунга у ижтимоий фаолият туфайли, мулоқот (кенг маънода) жараёнида эришади. Антрополог олимлар К.Леви-Стросс, К.Гирц ва бошқалар маданиятни инсонлар ўзаро муносабатларининг махсули сифатида таърифлайдилар. Инсонлар ўртасидаги мулоқот билан биргаликда воқеликдаги объектлар билан бўлган мулоқот маданиятнинг шаклланишида мухим рол ўйнайди.

Тил инсон ва воқелик муносабатида боғловчилик ва воситачилик вазифасини хам бажаради. Маданият воқеликнинг ажралмас қисмидир, тил эса ўзида шу воқеликни акс эттиради. Демак, бу ерда маданият билан тилнинг ўзаро узвий алоқадорлигини кўриш мумкин. Воқеликнинг ўзини хам миллий деб аташ мумкин ва бу миллийлик лисонда дунёни ўзига хос «кўриш», уни идрок этиш натижасида ўз аксини топади. $[9,45]$ 
Маданият ва тил муносабати масаласи мураккаб бўлиб, хар томонлама мушохадани тақозо этади. Тил ва маданиятнинг ўзаро муносабатини ўргана туриб, маданий лингвистика интеграл характерга эга бўлади, чунончи, а) фалсафий-маданий ва лингвистик анъаналар тизимининг яратилиши; б) тил ва маданиятни комплекс тасвирлашга ўтиш; в) хилма-хил тиллар ва маданиятларни қиёслашга замин яратилиши кабилар. Хусусан, бу икки феноменнинг умумийлик томонларини инобатга олиш зарур. B.Н.Телия фикрича бу умумийлик қуйидагиларда намоён бўлади:

1) маданият, худди лисон каби, инсон дунёқарашини акс эттирувчи онг шаклидир;

2) тил ва маданият ўзаро муносабатда, мулоқотда бўлади;

3) тил ва маданиятнинг субъекти-бу доимо индивид ёки ижтимоий гурух-жамоа шахс ёки жамият;

4) меъёрийлик (норма) тил ва маданият учун умумий хусусиятдир;

5) тарихийлик- тил ва маданиятнинг мухим хусусиятидир; $[10,20]$.

6) тил ва маданиятга «динамика - статика» қарама-қаршилиги бир хилда хосдир.

Тилшунос олим Ш.С.Сафаровнинг эътироф этишича, “тил ва маданият ўртасидаги муносабат изоморфликдан (айнанликдан) кўра кўпроқ хомоморфлик, яъни структуравий ўхшашликдан иборат деган хулоса хақиқатдан узоқ эмас. Хар қалай, хомоморфлик фақатгина бу икки тизимнинг таркибий тузилишида намоён бўлиб қолмасдан, уларнинг вазифа жихатидан хам хамоханглигида хам акс топса ажаб эмас. Тилнинг маданият учун «хизмат» қилишини маданий-маънавий бойлик, ахборот манбаларини сақлаш, уларни авлоддан-авлодга етказиш хамда маданий тушунчалар ва концептлар, стереотип ва эталон-намуналарни шакллантиришда бевосита иштирок этишини хеч қачон инкор этиб бўлмайди" $[9,45]$.

Хулоса қилиб айтганда тил оламни ўзгартиришнинг мухим усули, информацион, таъминот ва шахслараро муносабатни тартибга келтирувчи, тил таъсир этувчи восита сифатида кишиларни у ёки бу харакатга чорловчи, ижтимоий муносабатларни қайд қилишга ундовчи, деб тахлил қилинади. Жамоавий тажрибанинг энг мухим хазинаси сифатида тил маданиятнинг таркибий қисми хисобланади. Демак, маданият ва тил диалектик алоқадорликда бўлиб, ўзаро таъсирга эга ва тил маданият тизимида мухим ахамият касб этади.

\section{Адабиётлар:}

1. Голубкина К.В. Конгнитивные основания эпитетета в художественном тексте (на материале англоязыичной художественной прозы) Дисс... канд. филол. наук. М. 1998.

2. Гудков Д. Теория и практика межкультурной коммуникации. - М.: Гнозис. 2003.

3. Гумбольдт В.фон. Избранные труды по языкознанию: Пер. с нем. - М. Прог 1984.

4.Kemper T.D.How many emotions are there? Wedding the social and antonomic components//American Journal of Sociology, 1987.

5. Красных В. Этнопсихолингвистика и лингвокультурология. -М.: Гнозис.2002.

6. Lipka L.Prototype semantics or feature semantics: an alternative ? In: perspectives in language performance// Studies in linguistics, literary criticism, and language teaching and learning. Tiibengen: Narr, 1987.

7. Опарина Е.О. Лингвокультурология: Методологические осонования и базовые понятия.// Язык и культура: Сб.обзоров.-М.: ИНИОН РАН, 1999.

8. Пелепенко А.А., Яковенко И.Г. Культура как система. М.: Наука. 1988.

9. Сафаров Ш.Конгнитив тилшунослик. “Сангзор” нашриёти. Жиззах. 2006.

10. Телия В.Н. Русская фразеология. М. 1996.

11. Вежбицкая А. Сопостовление культур через посредство лексики и прагматики. М.: Языкиславянскойкультуры, 2001.

12. Yennemann Th. Categorial Grammar and the Order of Meaningful Elements // Linguistis Studies Offered to Joseph Greenberg.- Saratoga, 1997. 


\section{ТАШҚИ ИҚТИСОДИЙ МУНОСАБАТЛАР ВА ХАЛҚАРО МЕХНАТ ТАҚСИМОТИДА ИШЛАТИЛАДИГАН ТИЖОРАТ ТЕРМИНЛАРИНИНГ УЗИГА ХОС СЕМАНТИК ХУСУСИЯТЛАРИ}

Тошпулатов Д.А.

Мухаммад ал -Хоразимий номидаги тАТУ Самарқанд филиали ўқитувчиси

Информацион технологияларнинг жадал ривожланиши ва уларнинг турли жабхаларга жорий этилиши хозирги замон шахсиятининг шакилланиши ва ривожланишига ўз таъсирини кўрсатмоқда. Бунга яқол мисол сифатида реклама ва тижорат компанияларнинг ўз махсулотларини замонавий телевизор, видомагнитофон ёки информацион технологиянинг йирик имкониятларига эга булган, тарқалган ва синовдан ўтган воситалардан бири компютерлардир. Халқаро ареналарга муносиб ўринга эга бўлиш учун хам халқаро муносабат ва мехнат тақсимотида ишлатиладиган тижорат терминларини билишга тўғри келади.

Бу борада янги маълумртларнинг, жумладан рекламаларнинг кучли оқими, ва интернет тармоқларининг кириб келиши барча сохалар каби тижорат сохасида хам ўз таъсирини ўтказди. Бунинг оқибатида ярмарка ва кўргазмаларга хам тижорат лексемалари кенг ўзлаштириш бошланди. Халқаро алоқалар ва унинг кундан кун ривожланиши натижасида бунга талаб мижозлар орасида ошди. Қисқача тижорат термини хақида маълумот бериб ўтсак.

Тижорат Ўзбекистонда энди ривожланаёган соха бўлгани учун бу йўналишда хали кўп ишлар мавжуд эмас. Бор бўлган ишлар хам асосан иқтисодий нуқтаи назардан кўриб чиқилган. Тижорат лексикаси хам тарихан ривожланган ва унинг тарихи XVасрга бориб тақалади. Аллақачон ўша узоқ даврларда яшаган иқтисодиётчи олимлар, турли ижтимоий иқтисодий ходисаларни методик жихатдан ўрганаётганларида ўз асарларида бойлик, пул, товар, бозор каби махсус сўзлардан кенг ишлатганлар. Шу сабабли бозор иқтисодиёти билан боғлиқ бўлган янги тушунчаларнинг хаётимизда кириб келиши жараёнида бу сўзларнинг маъносини билишга уларни тахлил этишда интилиш барча қатламларида кучаийб бораяпти. Бу ишимиз орқали озгина бўлса хам замин яратишга харакат қилдик.

Бозор иқтисодиётига ўтилиши муносабати билан турли мулкчилик ва хўжалик юритиш усуллари вужудга келмоқда. Юртбошимиз Шавкат Мирзиёев 2017-2021 йилларда Ўзбекистон Республикасини ривожлантиришнинг бешта устувор йўналиши бўйича Харакатлар стратегиясини “Халқ билан мулоқот ва инсон манфаатлари йили”да амалга оширишга оид Давлат дастурини ўрганиш бўйича илмий услубий рисола Тошкент 2017 йилда маънавият нашриётида 3 бобида Иқтисодиётни ривожлантириш ва либераллаштиришнинг устувор йўналишлари бобида Президентимиз “Тараққиётнинг “ўзбек модели"ни амалга ошириш ва замонавий давлат барпо этиш борсидаги стратегик тамойилларга биз ўз ишимизда доим суянамиз[1.1]. Бу тамойиллар Ўзбекистонда бундан буён хам сиёсий, иқтисодий ва ижтимоий ўзгаришларни таъминлашнинг мустақил пойдевори хисобланади. Шуларни эътиборга олиб, "Харкатлар стратегияси" нинг учинчи йўналиишида макроиқтисодий барқарорликни янада мустахкамлаш ва юқори иқтисодий ўсиш суръатларини сақлаш, албатта, кадрларнинг билим савияси жудда катта ахамиятга эга[2]. "Бу ахолининг кўп қисмининг иқтисодий муаммоларга қизиқишни уйғотди. Натижада, республикамизда бозор иқтисодиётига бағишланган жуда кўплаб илмий - оммабоп китоблар ўзбек тилида нашр қилинмоқда. Ўзбекистон "Давлат тили хақида" ги қонунининг ижроси бўлажак мутахассиларни нафақат ўзбек тилида, балки халқаро тиллардан, яъни инглиз тилида бемалол сўзлаша оладиган, 
шунингдек бугунги дунё тараққий этаётган мамлакатлари билан ташқи иқтисод ва коммуникатция технологиялари орқали товар айири бошлаш, уни сотиб олиш ёки сотиш каби элетрон тижорат харидларни амалга ошириш учун хам ўзбек тили билан бирга чет тиллардан бирортасини ўқитишни даврнинг ўз тақозо этмоқда[3]. Буни асло инкор этиб бўлмайди. Шу туфайли олий билимгох ва ўрта махсус ўқув юртларида иқтисод фанлари нафақат ўзбек тилида, шунинг билан баробарида, халқаро тиллардан бўлмиш инглиз тилида ўқитилмоқда.

Иқтисодий фанларни ва унинг таркибида ўрганилиб келган тижоратга тегишли терминларни ўзбек тили ва инглиз тилларида ўқитиш шуни кўрсатдики хали бир қанча иқтисодий терминлар, айниқса, тижорат терминлари, тушунча ва иборалар ўзининг илмий ва назарий изохига ва таржимасига эга эмас. Шу уринда қуйидаги мисолларни келтиришимиз мумкин.

Бугунги ривожланаётган давлатлар қаторида қўшилишда албатта ташқи иқтисоди муносабатлар ва халқаро мехнат тақсимоти жудда катта ахамитга эга. Жумладан бизнинг республикамизда хам буни кузатиш мумкин. Шуни инобатга олган холда биз мақоламизнинг долзарблиги сифатда айнан шу сохада ишлатиладиган терминлар билан танишиб, тахлил қилдик. Тадқиқотлар шуни кўрсатдики тижорат терминлари анча қисмни ташкил қиллар экан. Ишнинг мақсади бу айнан шу йўналишда ишлатиладиган тижорат терминларини инглиз тили ва ўзбек тиллар мисолида қайдаражада иккиала тилда хам семантик маънога эга эканлигини кўрсатиб ўтилган. Бу ерда сўзларни мослашувига гувох бўламиз ва битишувларга хам.

Демак келинг уларни кўриб чиқсак; Ташқи иқтисодий муносабатлар ва халқаро мехнат тақсимоти - foreign economic relations and international devision of labour: Divide $v$. бўлмок, ажратмок, тақсимламоқ, феъл сўз туркуми вазифасида келмоқда.Dividend n. дивидент, от сўз туркуми вазифасида келмоқда.Dividend on account interim dividend дастлабки дивидент,Dividend payment - дивидентдан тўлаш, туиланиши лозим бўлган дивидент. Cash dividend -пул дивиденти Declared dividend - эълон қилинган дивиденд. Stock dividend - акциялар билан тўланган дивидент, Divisible a. - бўлинадиган, Division n. -1) бўлиш, ажратиш, тақсимлаш, 2) бўлим, бўлинма, қисм.International division of labour халқаро мехнат тақсимоти, Permanent a. - доимий, ўзгармас, давомли, узоқ давом этадиган, пишиқ, консолидация қилинган, Permanent address -доимий турар жой, Permanent assets - асосий воситалар, Permanent colour -барқарор, бузилмайдиган ранг, Permanent debt/ loan -консолидация қилинган қарз, заём, Permanent investment -узоқ, муддатли капитал куйилма, Permanent medium - барқарор валюта, Permanent repair жорий тузатиш, Permanent residence -доимий турар жой, Permanently adv. -доими, умрбод, узокмуддат, Resource п. -усул ёрдамичи восита, Resource industry -кон саноати, Limited resource -чекланган маблағлар, Source n. -манба, Source of income/ supply from a reliable/ an authentic source -даромад,таъминот манба, мўътабар манбалардан олинган, Scale n. -тарози палласи, шкала, масштаб, размер, миқдор,чизиғ, танга, Scale -car (pan) вагон тарози, Scale test (weight) - битишув йул орқали ясалган, тарозини текшириш, То turn the scales-устун келмоқ, хал қилувчи омиллар, Scale of charges -битишув йул орқали ясалган, йиғим, харажатлар шкаласи, тарифи, Scale of commissions (wages) - битишув йул орқали ясалган , коммиссион воситачилик тақдирлаш пул иш хұққ шкаласи, Large (small) scale -йирик майда масштабли кўламли, Natural reduced scale -натурал кичрайтирилган масштаб, Convention n. - конвенция, шарнома, битим, Conventional a. - келишилган, шартли, шартномали, 2) оддий қабул қилинган,анъанавий хама тан олган, Conventional rate - келишилаган, шартли курс, Conventional trade - оддий, олди сотий шартнома. Undertaking n. 1) кохона 2)мажбурият, кафолат , Turn - омбор, айланиш, уцзариш, навбат, бурилиш, тамом, охир, Тигn for the batter / for the worse -бошқарув йўл орқали ясалган, яхшилик, ёмонлик томон ўзграиш, Turn in the market - бошқарув йўл орқали ясалган, бозор конъюнктурасини ўзгариш, Tо take a good /bad turn - битишув йўл орқали ясалган яхши 
ёмон тус олмоқ , Ву/in /out turn - навбат билан, набатсиз , Loading turn -юклаш навбати, Tо ехесute orders in their turn -бюуртмаларни келиб тушиш навбатига кра, Turn/ end of the year turn -йил охири, то turn bankrupt -банрот бўлмоқ, To turn firm (weak) мустахкамламоқ, Tо turn advantage, disadvantage

Бу ўрганилаётган терминга ёки тушунчага нисбатан катта қизиқиш ўйғотишга даъват қилади. Бу ўринда терминлар билан ишлашда хам компютерларнинг ўрни сезиларлидир.

Адабиётлар :

1. Ўзбекистон Республикаси Президентининг “Ўзбекистон Республикасини янада ривожлантириш бўйича Харакатлар стратегияси тўғрисидаги”ПФ-4947-сон Фармони.2017йил 7 февраль.

2. Пардаев М.К. Русско-Узбекский словарь экономически терминов торговли Тошкент Ўқитувчи 1992 йил 5 бет

3. Т.Бедладзе, Ш.Ниязматов, У.Уватов “Инглизча ўзбекчи ва русча тижорат луғати” тахрири остида чиқарилган луғат Т. 1995й. 45-б..

4. www.minecomoy.uz.

\section{ХОЖА АХРОРИЙ ВАЛИЙ ТАСАВВУФИЙ ТАЪЛИМОТИДА ИНСОНПАРВАРЛИК ҒОЯЛАРНИНГ ТАРБИЯВИЙ АХАМИЯТИ.}

\section{Хамдамов Ислом Акрамович Самарқанд давлат чет тиллар институти ўқитувчиси}

Annotation: This article discusses the moral and humanistic views of Khoja Ahror Valiy. Socio-moral views of Khoja Ahror Valiy are of paramount importance in the modern era of globalization, helping to protect the younger generation from the harmful effects of destructive ideas and ideologies.
Key words:

humanism, morality, peace, harmony, social, youth, education, globalization, spiritual threat.

Хазрат Хожа Убайдуллох Ахрор (1404-1490) Мовароуннахр халқларининг XV аср иккинчи ярмидаги ижтимоий-сиёсий, маданий тафаккур ривожида мухим ўрин тутган. Нақшбандия тариқатининг назарий, амалий жихатларини бойитиб, бу таълимотнинг машхур бўлишига хисса қушган тарихий шахсдир. Нақшбандия тариқати, ахрория таълимотининг асосий масалаларидан бири инсон учун қайғуриш, унинг маънавий камолотини юксалтириш бўлиб, хозирга қадар ахамиятини йўқотмаган. Хар қандай оғир ва мураккаб шароитда хам ота-боболаримиз ўзлигини йўқотмасдан, маънавий хаёт мезонлари, одоб-ахлоқ қоидаларига амал қилиб, комиллик сари интилиб яшагани бугун хам ибрат манбаи бўлиб, куч-қувват бағишлаб келмоқда(1-7).

Хожа Ахрор Валий Бахоуддин Нақшбанднинг ушбу сўзларини кўп такрорлаган. “Бизнинг тариқимиз сухбатдур ва хилватда шухратдур ва шухратда офат. Хайрият жамъиятдадур ва жамъият сухбатда, бу шарт билаки, бир-бирига нафй бўлулғай”(2-263) яъни халқ билан сухбатда бўлиш, уларнинг дардларига шерик бўлиш, Аллох розилиги йўлида халққа хизмат қилиш, қалбни бир лахза бўлса хам Аллох зикридан ғафлатда қолдирмай, хамиша огох бўлишга чорлаган.

Хожа Ахрор йирик мулкдор бўлишига қарамай ўзини сўфий деб хисоблаб, атрофдагилар учун аввало шайх, яъни тасаввуф тарғиботчиси эди. У ўз атрофига муридларини тўплаб, муроқаба, зикр тушишни давом эттирар дунё лаззатларига берилмаслик, мехнатни севиш, инсонларга нисбатан мехр-оқибатли бўлиш, биродарлик ва тинчликсеварликни тарғиб қилишда давом этарди. Ўзидаги фазилат ва гўзал холатларни “мен бу сабоқни сўфийянинг китобидан олғоним йўқ турур, балки одамларнинг хизматидин олдим, на улким манга ўргатган бўлсалар. Аммо хизматнинг хосияти шул турур. Хизмат манинг марзом ва мухтор ва махбубам турур"(8-212) деб 
изохлаган. Хожа Ахрор Валий “Халол ризқ топиш хар бир мўмин учун вожибдир” деган хадисга бир умр амал қилиб, мехнат ва машаққатни ўзига ихтиёр этган. Хожа Ахрор Валийнинг энг олижаноб мақсади халқ манфаатларидан келиб чиққан холда мамлакатни бошқаришда хукмдорларни тўғри йўлга бошлаш, фуқаро ва амалдорлар орасида юзага келадиган низоларни бартараф этиб, мамлакатда осойишталик ва барқарорликни ўрнатишга қаратилган эди. Бу тадбир Хожа Ахрор Валийнинг динийирфоний фаолиятига ижтимоий-сиёсий тус берди, тариқат арбобини улкан жамоат арбобига айлантирди. Шу тариқа Хожа Ахрор Валийнинг халқимиз тарихидаги энг буюк хизмати хукмдорларни адолат ўрнатишга ундагани ва бунга имкон қадар эришганини гувохи бўламиз, мамлакатнинг заволи ва хароб бўлишидан андиша қилсинлар, хеч вақт раият ва фуқаро ахволидан хабарсиз қолмасинлар, чунки салтанат ва хукуматга эга бўлишнинг асл сабабчилари бу фуқаро ва раиятдирлар(3-10).Тариқат эса жамият ва дунёвий хаёт билан боғланиб, катта ижтимоий-сиёсий кучга айланди.

Хожа Ахрор даврига келиб Нақшбандий ахрория ўзининг энг юқори палласига кўтарилиб, катта маънавий обрўга эга бўлган(4-137). Жамиятда сиёсий фитна ва маккорликлар авжига чиққан махалда Хожа Ахрор рақибларини хайрон қолдирувчи энг ишончли восита тинчликларварликдан фойдаланарди. Бу ўринда A.Н.Болдиревнинг XV асрнинг иккинчи ярмида Марказий Осиё хаётида Хожа Ахрорнинг роли хусусидаги хулосасига қўшилмасликнинг иложи йуқ: Икки қирқ йилликни яъни Улуғбек ва тож киймаган хукмдор Хожа Ахрор даврларини қиёсласак, Хожа Ахрорнинг тарихга олиб кирган янгилиги яққол намоён бўлади: бу тинчлик, мамлакатнинг юз минглаб оддий мехнаткашлари учун жон куйдирилган осойишталик эди (5-59).

Хожа Ахрор хукумдорларнинг сиёсат юргизишида, солиқ ва тўловлар масаласида инсоф ва адолат мезон бўлишига тарафдор эди.Хожа Ахрор Валий “фуқаро осойишталиги, хунар ва тижорат ахлининг равнақи учун хар қандай бахсли муаммоларни келишув, муроса йўли билан, хал этган"(6-29).

Хожа Ахрор Валий ўз ихтиёридаги ерлардан келадиган даромадни ўзи учун сарфламай, уни юртни ободонлаштириш, халқнинг оғирини енгил қилиш, солиқларини тўлаш, мадраса, масжид, хонақох, шифохона, мусофирхона қуриш ишларига сарфлаган(7-70) ва бу ишларни ахлоқий мажбуриятдан эмас, балки қалб хузури билан амалга оширган. Мехнатнинг меваси хеч қачон бойлик бўла олмайди. Бойлик тўплашга интилиш керак эмас. Аслида инсон ўз дунёсини маънан бойитиши учун харакат қилмоғи керак(8-230). Шунинг учун хам бу зотнинг номи халқ ичида шу кунгача ўз фахру ифтихорини, мухтарам зот сифатини сақлаб қолган.

Тасаввуф фалсафасини ўрганиш, ғоят теран тафаккурни талаб қилади, чунки тасаввуф кўп қиррали, зиддиятли маънавий ходиса. Мехнаткаш халққа яқин бўлган сўфийлик таълимоти кенгайиб оммалашиб борди,“халқ дини” деб номлана бошланди.Тасаввуф ўзининг ижтимоий, маънавий-мафкуравий хусусияти билан диний ва этник бағрикенгликни ифодалар эди. Шу туфайли тасаввуф ислом динининг, унинг инсонпарварлик ва қардошлик ғоялари Мовароуннахрнинг хаттоки чўл-сахроларида яшовчи кўчманчи халқлар, қабилалари орасига кириб боришига ёрдам берди. Айтиш кераки, тасаввуф Мовароуннахр мусулмонлари ижтимоий, шахсий хаётларининг барча томонларини ўзининг диний маънавий таъсири билан бутунлай қамраб олди. Ўрта асрлардаги барча хукмдорлар тасаввуфнинг машхур авлиё-шайхларини ўзларининг маънавий рахнамолари, деб қабул қилганликлари бунинг исботидир.

Алишер Навоий, Абдурахмон Жомий, Махдуми Аъзам, Захириддин Мухаммад Бобур, Султон Абу Саид, Султон Ахмад каби ўз замонасининг етук алломаю султонлари Хожа Ахрор Валийни ўзларига маънавий пиру муршид деб билганлар. Шуни таъкидлаш зарурки, Марказий Осиё сўфизми, айниқса, Нақшбандия-ахрория алломаларининг тариқатлари бошқа сўфиёна тариқатлардан фарқи шундаки, улар анъанавий сўфизмга хос аскетизм (таркидунёчилик) ва танхоликда хаёт кечириш каби удумлардан воз кечиб, 
одамларни жамоа бўлиб яшашга, мехр оқибатли бўлишга чақирди. Камтарона турмуш, мехнатсеварлик, адолат ва хақиқат ғояларини тарғиб қилди.

Хожа Ахрор Валийнинг бундан етти аср муқаддам айтган доно сўзлари бугунги ва эртанги кунимиз, ёш авлод маънавияти, баркамол авлод тарбиясига бевосита дахлдордир. Ёш авлодни миллий-маънавий ва диний қадриятлар билан бирга дунёвий билимлар асосида тарбиялаш, уларнинг онги ва тафаккурида ўзликни англаш, миллий қадриятларга хурмат эхтиром туйғуларини жонлантириш жиддий ахамият касб этади. Хожа Ахрор Валийнинг мусулмон бўлмоқ, фуқаро манфаатлари учун яшамоқ эканлигини дастуруламал қилиб яшаган ибратли хаёти хар бир инсон учун тарбия вазифасини ўтайди.

Ўзбекистоннинг ижтимоий-иқтисодий ва маънавий-маърифий тараққиётида ислом маърифати, илми ирфон, тасаввуф ғоялари ўзига хос қирралари билан ижобий таъсир кўрсатади. Хозирги тахликали дунёда, турли низо ва адоватлар хали бархам топмаган мураккаб бир вазиятда Хожа Ахрор Валий илгари сурган эзгу ғоялар ўз ахамиятини йўқотмаган, аксинча, бу зотнинг ибратли хаёти ва орифона асарларини ўрганиш ва тўғри талқин этиш бугунги маънавиятимиз тараққиёти учун жуда мухимдирки, тарихий хотираси уйғоқ миллат хеч қачон таназзулга юз тутмайди. Бугунги кунда хам тасаввуфнинг ёшлар маънавий камолоти ва рухан поклигини тарбиялашдаги ахамияги катта. Баркамол авлод тарбияси хар бир маърифатли жамиятнинг келажагидир.

\section{Адабиётлар.}

1. Каримов И. Юксак маънавият - енгилмас куч.Т. “Маънавият”, 2008. 7-бет.

2. Алишер Навоий. Насойим ул-мухаббатмин шамойим ул-футувват. Мукаммал асарлар тўплами.Йигирма жилдлик. 17-жилд /Нашрга тайерловчилар. С. Ғаниева, М. Мирзаахмедова. Арабча ва форсча матнларни таржима қилиб, нашрга тайерловчи ва масъул мух.С Рафиддинов. Т.- “Фан”, 2001. Б-263.

3. Ботирхон Валихўжаевнинг “Буюк маънавий муршид” рисоласи.1993.

4. Algar H. The Nagshbandi order. P-137.

5. Болдырев А.Н. Ещё раз к вопросу о Ходже-Ахроре. Духовенство и политическая жизнь на Ближнем и Среднем Востоке в период феодализма. М. 1985. С-59.

6. Махмудов Н. Ахрорийнома. - Самарқанд: Зарафшон, 2003. 29-бет.

7. Валихўжаев Б. Хожа Ахрор тарихи. Т.Ёзувчи, 1994.Б-70.

8. Фахруддин Али Сафий. Рашахоту айнил-хаёт (Оби хаёт томчилари). Таржимон Домла Худойберган ибн Бекмухаммад. Табдил қилиб, нашрга тайерлаганлар, кириш сўз муаллифлари: М.Хасаний, Б.Умрзоқ - Т.: Абу Али ибн Сино номидаги тиббиёт нашриети, 2004.Б- 230.

\section{ХИТОЙ ВА ЎЗБЕК ТИЛЛАРИДА ЭВФЕМИЗМЛАРНИНГ ЛИНГВОМАДАНИЙ ТАДКИҚИ}

\section{Шамсиева Шохистахон Кудратуллаевна Тошкент давлат шарқшунослик университети ўқитувчиси E-mail: shohistaxon81@mail.ru}

Annotation: This article is devoted to the linguistic study of euphemisms in Chinese and Uzbek. Old age, death, and general and specific aspects of euphemisms that characterize a woman's appearance are highlighted during puberty, indicating their role in language and culture. It was found that such cognitive traits as Eastern humility, shame, and chastity of both nations are reflected in euphemisms. The study of euphemisms makes it possible to get a deep insight into the mentality of the people, to have a full understanding of their national culture, values, customs, moral norms, the national character of the owner of the language, as well as the interaction of language and culture.

Key words : euphemisms, linguoculture, intercultural, communicati on, death, old age 
Эвфемизмларнинг келиб чиқишида ижтимоий асос ётади. Кишилар баъзан бошқалар билан мулоқот чоғида ўзлари хохлаган нарсани тўғридан-тўғри айта олмайдиган ёки ибораларнинг ўз маъносида қўллаб, сухбатдошларини ноқулай ахволга солиб қўядиган вазиятлар билан тўқнашиб қоладилар. Бундай қийин вазиятлардан чиқиб кетиш мақсадида, кишилар ўз фикр-мулохазаларини воситали, “ўраб-чирмаб” ифодалашга харакат қиладилар. Бунинг натижасида эвфемизмлар юзага келади $[1,66]$. Эвфемизм ифодага ижобий ёндашувни юзага келтириш мақсади билан амалга оширилади[2,284].

“Эвфемизм" термини юнонча "euphemism" < “eu" - "яхши" ва "phemism" - "нутқ", “сўзлашув"дан келиб чиққан бўлиб, сўзма-сўз таржима қилганда "яхши аломатли сўз" маъносини ифодалайди. "Routledge Dictionary of Language and Linguistics" (2000)да “эвфемизм - кишилар учун ишлатилиши ёқимсиз ва беадаб бўлган айрим сўзлар ўрнига ноаниқ, кўп маъноли сўзларни қўллаш ва бу орқали ўзларини ноқулай холатлардан чиқаришга уринишларини ифодалайдиган ўзига хос бир усулдир", деб изохланган.

А. Хожиев эвфемизм ходисасини шундай изохлайди: “Эвфемизм - нарсаходисанинг анча юмшоқ шаклдаги ифодаси; қўпол беадаб сўз, ибора ва табу ўрнида қўпол ботмайдиган сўз (ибора)ни қўллаш"[3,131].

Хитойлик тадқиқотчиларнинг ишларида хам эвфемизмларга ўзига хос таърифлар берилганини кўриш мумкин. Чунончи, Ванг Сижиенинг фикрича, тўғридан-тўғри гапиришни хохламайдиган ва гапириб бўлмайдиган холатларда уни буриб, айлантириб гапириш орқали ўз мақсадига эришишга эвфемизм дейилади" $[4,10]$. Ву Жиадженнинг қайд этишича, маълум бир тил доирасида кишилар муайян сўзларни тўғридан-тўғри айтмасдан уларни юмшатиб ифода этишади. Бундай ифодалаш стилистик услубда эвфемизм дейилади [5,23]. Тилшунос олим Ли Цзюньхуанинг фикрича, эвфемизмлар тақиқланган, айтилиши ножоиз, қўпол, одоб-ахлоқ меъёрларига зид бўлган сўз ва ифодалар ўрнига юмшоқ, қулоққа хуш ёқадиган хамда у ёки бу сабабга кўра қўлланишли бўлган сўз ва ифодалардир[6,10]. Шунингдек, хитойлик олимлар томонидан эвфемизмларнинг уч турдаги: “табудан сақланиш”, “одоб” ва “бўёқдорлик” каби функциялари қайд этилади[7,56-57].

Тилдаги аксарият эвфемизмлар табуларнинг ўрнида алмашиб қўлланилади. Табуга учраган сўз ёки ибора ўрнида тўғридан-тўғри эвфемизм қўлланади. Ўлим хам табудир. Шунга кўра ўлимни англатадиган хар қандай тушунча ва ифодаларнинг хам табу хисобланиши табиийдир. Хатто ўлим билан боғлиқ маросимлар, урф-одатларни хам тилда эхтиёткорлик билан акс эттиришга харакат қилинади.

Ўлмоқ тушунчаси энг кўп қайта-қайта эвфемалаштирилган, юзлаб бадииймажозий, индивидуал, окказионал, нозик услубий хусусиятларга эга бўлган эвфемик воситаларнинг шаклланишига сабаб бўлган. Хусусан, буюк шахслар ўлганда, уларнинг номларини тилга олиш бутунлай ман этилган. 1916 йилда Григорий Распутин ўлдирилганда,унинг исми ва фамилиясини, хатто лақаби - “оқсоқол” (“старец") нитилга олиш тақиқланган. Журналистлар “Бир машхур шахс ўлди” (“Умер одно значительное лицо") эвфемасини қўллашган ва хамма бу шахс Распутин эканлигини англаган"[8,99].

Ўлим дунё яратилгандан буён инсонни доимо уйлантириб, хаёлини банд қилиб келган ходисалардан биридир.Ибн Сино “Ўлим қўрқувидан қутилиш" деб номланган рисоласида ўлимдан қўрқишнинг сабабларини қуйидагича изохлаган: “1. Ўлим хақиқатини билмаслик. 2. Ўлгандан кейин кишининг бошига нималар тушишини тасаввур қила олмаслик. 3. Бадан чириб йўқ бўлиб кетгандан кейин кишилик ва шахснинг тамоман бўшлиққа сингиб кетиши ва ўзи ўтгандан кейин дунёда хаёт давом этаверишини тахмин қилиш. 4. Ўлимдан олдинги ва ўлимга олиб келган касалликларнинг азоб ва изтиробларидан бошқа ўлим учун яна алохида азобнинг борлигини тахмин қилиш. 5. Ўлгандан кейин ўзини жазо ва қийноқлар кутаётганига ишониш. 6. Ўлгандан кейин қаерга боришини ва бошига нималар тушишини билмасдан 
саросимага тушиш. 7. Орқасида қолаётган мол-мулки ва меросини ўйлаб қайғуга ботиш" $[9,156]$. Минглаб йиллар давомида ўлим қаршисида чорасиз қолган инсонлар ўлим қўрқувини енголмадилар. Ўлим хақлиги билан бирга, ўлимдан кейинги мавхумлик, йўқ бўлиш, яқинларидан, жамиятдаги мавқеидан айрилиш ва ўлим пайтида азоб чекиш қўрқуви ўлимни дахшатли бир хақиқатга айлантирди $[10,108]$.

Аксарият кишиларнинг фикрича, касаллик ва жарохат олиш инсонга берилган илохий жазо бўлиб, бу жазо илохий мавжудотларнинг қахр-ғазаби туфайли юзага келади. Инсон ўзининг хаёти давомида қилган ёмон хатти-харакатлари учун жазо кутади[11,13]. Хитой ва ўзбек тиллари типологик жихатдан турлича бўлишига қарамай, уларнинг хар иккаласи хам жуда бой эвфемик қатламга эга. Ўлим билан боғлиқ эвфемизмлар, асосан, метафора, метонимия, ўхшатишлар, фразеологизмлар хамда айрим грамматик воситалар ёрдамида хосил бўлади.

Инсон икки қарама-қаршилик - эркак ва аёл сифатида гавдаланади. “Эркак - аёл” зиддияти инсоният маданиятининг пойдеворини ташкил қилади. Дунё хақидаги қадимий тасаввурларда калом, рух - бутун борлиқнинг отаси, материя - она бўлиб, уларнинг қўшилиши натижасида Олам ва ундаги барча мавжудотлар вужудга келган. Борлиқнинг антропоморф моделида мажусийларнинг тасаввурига кўра, аёл тубсизликка тенглаштирилган бўлишига қарамай, оламдаги бутун тирик мавжудотнинг дастлабки манбаси хисобланган. Шунингдек, бир томондан аёл - тақдир тимсоли, иккинчи томондан эса - зулмат, гунох, ёвузлик тимсоли бўлган[12,81].

Қадимги Хитой фалсафасида бутун олам икки қарама-қарши: “ин”

(阴yīn) салбий (аёл) ва “ян” (阳 yáng) ижобий (эркак) қутбларга ажратилган. Яъни, “ян” ва “ин” бутун борлиқдаги қарама-қаршиликлар образини ифодалаган. Масалан: аёл-эркак, ўғилота, хотин-эр, қарол-хукмдор ва х.к. Энг қадимги маданиятлардан бири бўлган Хитой маданияти жамият ривожланишининг барча босқичларида одамлар ўртасидаги муносабатларнинг поғонали тизимини сақлаб қолди. Ушбу тизимда Хитой аёли пастки ўринлардан бирини эгаллади. Қадимги даврларда хатто қизалоқларга исм қўйилмасдан улар “бир, икки, уч”, деб чақирилган. Конфуций асарларида хам аёллар хақидаги мулохазалар деярли учрамайди, учраганлари хам салбий мазмун касб этади: 子曰: “唯女子与小人为难养也。近之则不孙, 远之则怨。”- Устоз деди: “Фақат аёллар ва хақир одамлар билангина муомала қилиш мушкул. Яқинлашсанг, такаллуфсизлик қиладилар. Йироқлашсанг, нафратланадилар" $[13,122]$. Одатда, хукмрон тузумга боғлиқ холда жамиятдаги аёлларнинг мақоми хам ўзгариб турган.

Хозирги кунда аёлнинг жамият ижтимоий-сиёсий хаётидаги ролининг ортиб бориши аёл хақидаги тасаввурларнинг хам ўзгаришига олиб келди. Бу ўз навбатида, “аёл" тушунчаси билан боғлиқ бўлган замонавий лингвомаданий тадқиқотларни олиб борилишига кенг йўл очиб берди. Бинобарин, хитой ва ўзбек лингвомаданиятларида “аёл” тушунчаси билан боғлиқ эвфемизмларни тадқиқ этиш бугунги гендер тенглиги масаласини хал этишда мухим ахамият қасб этади. Хитой ва ўзбек тилларида "аёл" тушунчаси билан боғлиқ эвфемизмларни аёлнинг ёши, турмушга чиқиши, хомиладорлиги, ахлоқи ва ташқи кўриниши сингари мавзуий гурухларга ажратиб ўрганиш мақсадга мувофиқдир.

Ёш “антропологик хусусият" бўлиб, унга биологик ўлчов, “ижтимоий омил” ва "маданий ходиса" сифатида концептуал ёндашиш мумкин[14,145]. Хитой ва ўзбек лингвомаданиятларида “ёш” муайян маънода ўхшаш образлар, яъни одам, хайвон, ўсимликларнинг мавжуд бўлиш вақтини билдиради.Бироқ шуни таъкидлаш жоизки, ўзбек тилида ёш сўзи “туғилган вақтдан бошлаб яшаб ўтказиладиган йиллар жами”, хитой тилида эса “бола онасининг қорнида пайдо бўлган вақтдан бошлаб яшаб ўтказиладиган йиллар жами” маъносини англатади. Чунки қадимги хитойликлар она қорнидаги даврни хам инобатга олиб, ўз ёшларини 1 йилга орттириб хисоблашган. 
Хитой маданиятида “Каттага хурмат, кичикка мухаббат" тамойилига амал қилиб келинади. Бинобарин, кексалар донолик ва бой тажриба рамзи хисобланади. Кексалар жамиятда хар доим ўз ўрнига эга бўлиб, уларга хурмат-эхтиром кўрсатилади. Чунончи, хар йили重阳节chóng yáng jié - “Қўшалоқ тўққиз байрами (ой тақвимидаги 9-ойнинг 9санаси, яъни Хризантемалар байрами)” хамда 老人节 lăorénjié -“Кексалар байрами” нишонланиб келинади. Ўзбек маданиятида хам катта кишилар олдида одоб сақлаш, уларнинг гапи, ўгити, панд-насихатларига қулоқ солинади. Бинобарин, “Каттага хурмат, кичикка шафқат” нақлига амал қилинади. Хитой ва ўзбек лингвомаданиятида кексалик билан боғлиқ эвфемизмларни “кексалик фаслини ифодалайдиган эвфемизмлар”, “йирик саналарни ифодалайдиган эвфемизмлар”, “донолик ва тажрибани ифодалайдиган эвфемизмлар”, “мурожаатни ифодалайдиган эвфемизмлар” сингари мавзуий гурухларга ажратиш мумкин.

\section{Адабиётлар:}

1. Wang Xiaoling, Zhang Meng, Dong Hailin. Cross-Cultural Contrastive Study of English and Chinese Euphemisms // Cross-Cultural Communication. Vol. 8(6). Canadian Academy of Oriental and Occidental Culture, 2012. -P.66

2. Арнольд И.В. Лексикология современного английского языка. -М.: Флинта, 2012. -С. 284

3. Хожиев А. Тилшунослик терминларининг изохли луғати. -Тошкент: ЎзМЭ, 2002. -Б. 131.

4. 王希杰, 汉语修辞学 (修订版) 北京 : 商务印书馆, 2004.

5. 吴家珍, 修辞与逻辑, 北京：广播出版社, 1982.

6. 李军华, 汉语委婉语研究, 北京 : 中国社会科学出版社, 2010.-P. 10.

7. 束定芳.2013。认知语言学研究方法, 研究现状, 目标与内容[]。外语研究 (3) : 52-56.

8. Омонтурдиев А.Ж. Эвфемик воситаларнинг функционал-услубий хусусиятлари. Филол. фанлари номзоди ... дисс. -Тошкент: 1997. -Б. 99-100.

9. Hökelekli Hayati. "Ölüm ve Ölüm Ötesi Psikolojisi”. Uludağ Üniversitesi İlahiyat Fakültesi Dergisi. 1991. III/3 -S. 156-157.

10. Örnek Sedat Veyis. Anadolu Folklorunda Ölüm. -Ankara: Ankara Üniversitesi Dil ve Tarih Coğrafya Fakültesi Yayınları, 1971. -S. 108-109.

11. 邵军航, 汉语委婉语研究, 上海, 2010年

12. Маслова В. А. Лингвокультурология: Учеб. пособие для студ. высш. учеб, заведений. -М.: Издательский центр «Академия», 2001. -С. 81.

13. Конфуций. Сухбат ва мулохазалар. / Махмутходжаев М., Исматуллаева Н. таржимаси. Тошкент: Янги аср авлоди, 2014. - Б 122.

14. Диалог культур. Концепции развития лингвистики и лингводидактики / И. К. Кириллова и др. -М.: НИУ МГСУ, 2015. -С. 145.

\section{THE IMPORTANCE OF DEVELOPING THE MARKET OF MEDICAL SERVICES IN AN INNOVATIVE ECONOMY}

\section{Rakhimova Sadokat Makhmudovna Urgench state University \\ Tourism and economy faculty, PhD student E-mail: Sadoqat8888@mail.ru}

Annotation: This article describes the current state of the medical services market in the context of innovative economy development In addition, measures to ensure the quality, efficiency and affordability of guaranteed health services have been studied and in-depth analysis of market systems of medical services in developed countries. The study investigated many theories of economists in foreign countries, especially in analyzing the market for medical services.
Key words :

medical service, social protection, economic effect, social effect, health

insurance,health care,medical activity, medical culture, private medical system, compulsory health insurance. 
INTRODUCTION. The role of the service sector in the development of the innovative economy is increasing significantly. Market economy envisages regulation of market mechanisms in society and creation of conditions for production and services through which economic relations are formed.

In recent years, technological diversification of the economy has had an impact on the development of the country's health care services market and put some demands on it.

According to the World Health Organization (WHO), health services are a special human need, and as a result of their consumption, health needs are met, and consumed health services are both socially and economically important. [1]

Health care is a profitable activity, but the service company needs to pay special attention to improving the health (social protection) and rehabilitation of the public property, as well as its social importance.

Our country is pursuing reforms to further develop the health services market through the creation of a new and modern health care system, the regulation of the forms of ownership of healthcare providers and the use of state benefits.

The Strategy of Action for the Five Priorities of Development of Uzbekistan for 20172020, adopted by the President of the Republic of Uzbekistan, sets the following priorities for further improvement of health care:

First, to learn from the experience of developed countries in the provision of quality health services to the population, to implement measures to improve the quality of life through the introduction of high technologies in the provision of health services; Secondly, the gradual implementation of reforms to improve the availability of medical and social services and the widespread introduction of the compulsory health insurance system to provide services to the entire population; thirdly, the development of electronic health services centers in the country in the provision of health services, and as a result, the history of health care consumers is focused on creating a system to improve their statistical data. [2]

In addition, a number of decisions were made in this field. - State Program on strengthening reproductive health of the population of Uzbekistan in the years of protection of maternal and child health. In the framework of a number of adopted decisions, the development of the market of medical services in the Republic of Uzbekistan, development of investment programs, attraction and provision of permanent and effective access to medical services by the population [4] [5].

On April 1,2017, the issues of improving the quality of medical services in order to control the state of the prices for paid and free medical services in the country and ensure their provision by the state medical and preventive institutions on April 1, 2017 It is reflected in the Decree of the President of the Republic of Uzbekistan № PP-2863 "About measures for further development of the private sector in the health sector", adopted by the President Sh.M. Mirziyoyev [6].

RESULT AND DISCUSSION. The size, structure and level of development of the services sector are important in assessing the economic status of the country.

The major conference, "The Economics of Medical Care," organized by the American Economic Association in 1951, is an important historical event in the study of the role of medical services in the market economy of the world. The establishment of scientific and research centers, research on economic aspects, and a special focus on reducing the economic harm to the population in the health sector have been studied as a first priority [7].

The World Health Organization's first meeting was held in 1973, addressing health issues in countries around the world. The summit will evaluate the biggest health impact recovery, consolidation of human health, and the amount of financial resources spent by the country in the national economy and their revenues.

American economists play a major role in the development of the medical services market. Economist Kenneth Joseph Arrow in his article "Health Wellbeing and Economics" 
addresses the disadvantages and contradictions of the medical services market explains as follows;

- insufficient information about health care consumers, in particular insured persons, vaccinated for disease prevention,

- Diagnosis of the patient,

- In general, the level of access to health services (medical culture) is considered by the population to be the main disadvantage of the medical services market. This determines the scope and scope of the medical services market, and the increasing demand for services and demand causes expensive trends in the healthcare sector . In modern economics, researchers $\mathrm{L}$. Berry, V. Zaytaml and A. Parasuraman analyzed the basic concepts such as variability in the quality of health services, the concept of health care, and the effectiveness of health care. According to the economists, the development of the market for medical services in the country is a social phenomenon, and then it is deeply studied how to improve the health and economic relations of the population through the provision of medical services. Researchers have extensively analyzed a number of concepts in health care services such as "health", health care "medical care", and "medical activity", the social effect of health care, economic efficiency.

\section{References :}

1.Финансирование систем здравоохранения.Путь к всеобщему охвату населения медикосанитарной помощью.WHO Library Cataloguing-in-Publication Data.The world health report: health systems financing: the path to universal coverage.2010y

2. Decree of the President of the Republic of Uzbekistan dated February 7, 2017 № P-4947 "On the Strategy of Action for the Further Development of the Republic of Uzbekistan". Collection of Laws of the Republic of Uzbekistan, 2017, № 6, Article 70

3.Resolution of the Republic of Uzbekistan "On Sanitary Epidemiological Survival of the Population, Decision of the Republic of Uzbekistan-363 August 25, 2015

4. Decision on the prevention of iodine deficiency diseases, 3. Decision of the Republic of Uzbekistan- 97 03.05.2017

5. Resolution of the Government of the Republic of Uzbekistan No. PP-2221 "On the State Program for the Protection of Reproductive Health of the Population of Uzbekistan for 2014-2018"

6.On April 1, 2017 by the decree of the President of the Republic of Uzbekistan Sh.M. Mirziyoev "About measures for further development of the private sector in the sphere of healthcare" DP-2863

7. А. Р. Ильясова Основы экономики здравоохранения. Учебное пособие Казань, 2019.86 с. 


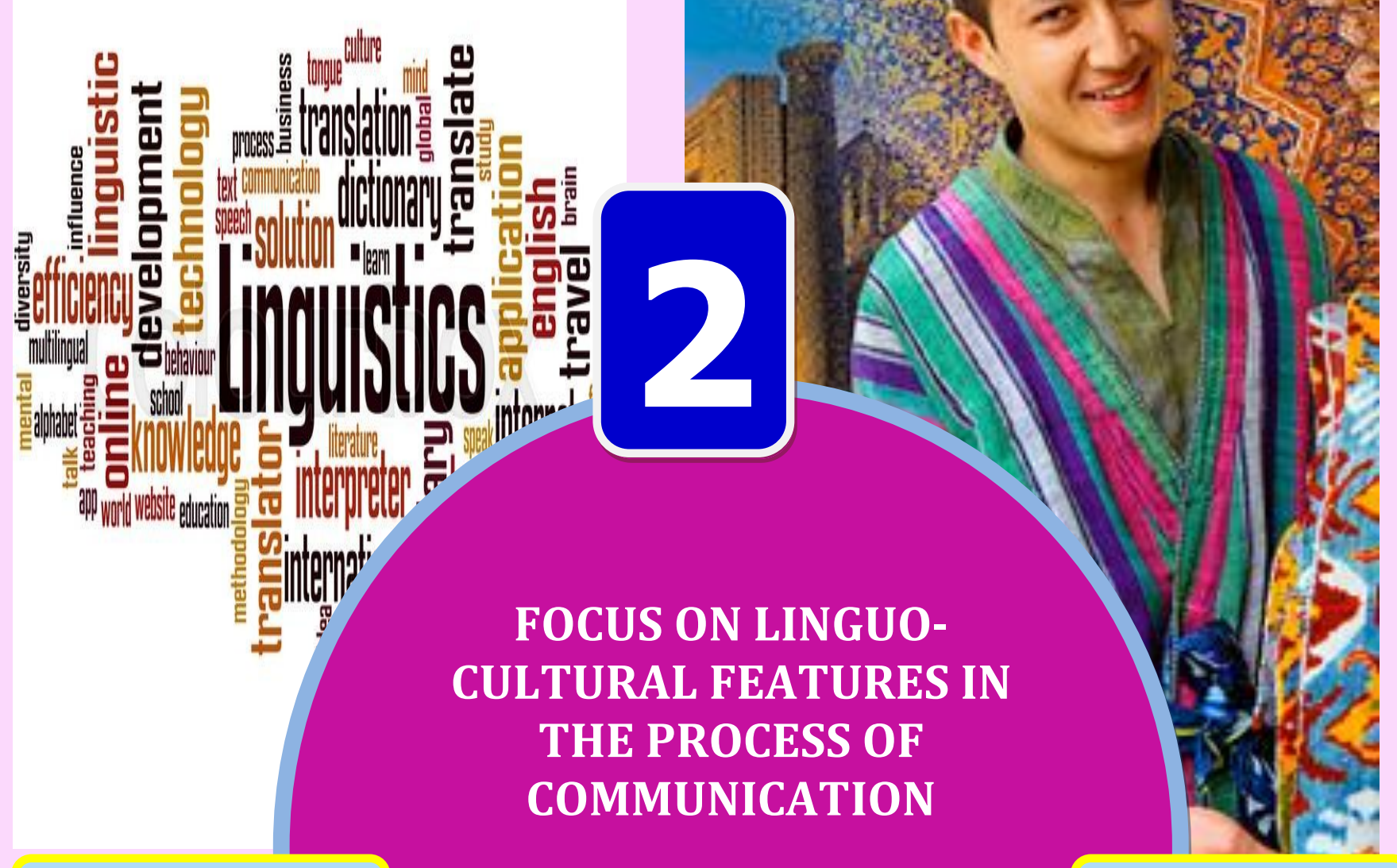

\section{SECTION}

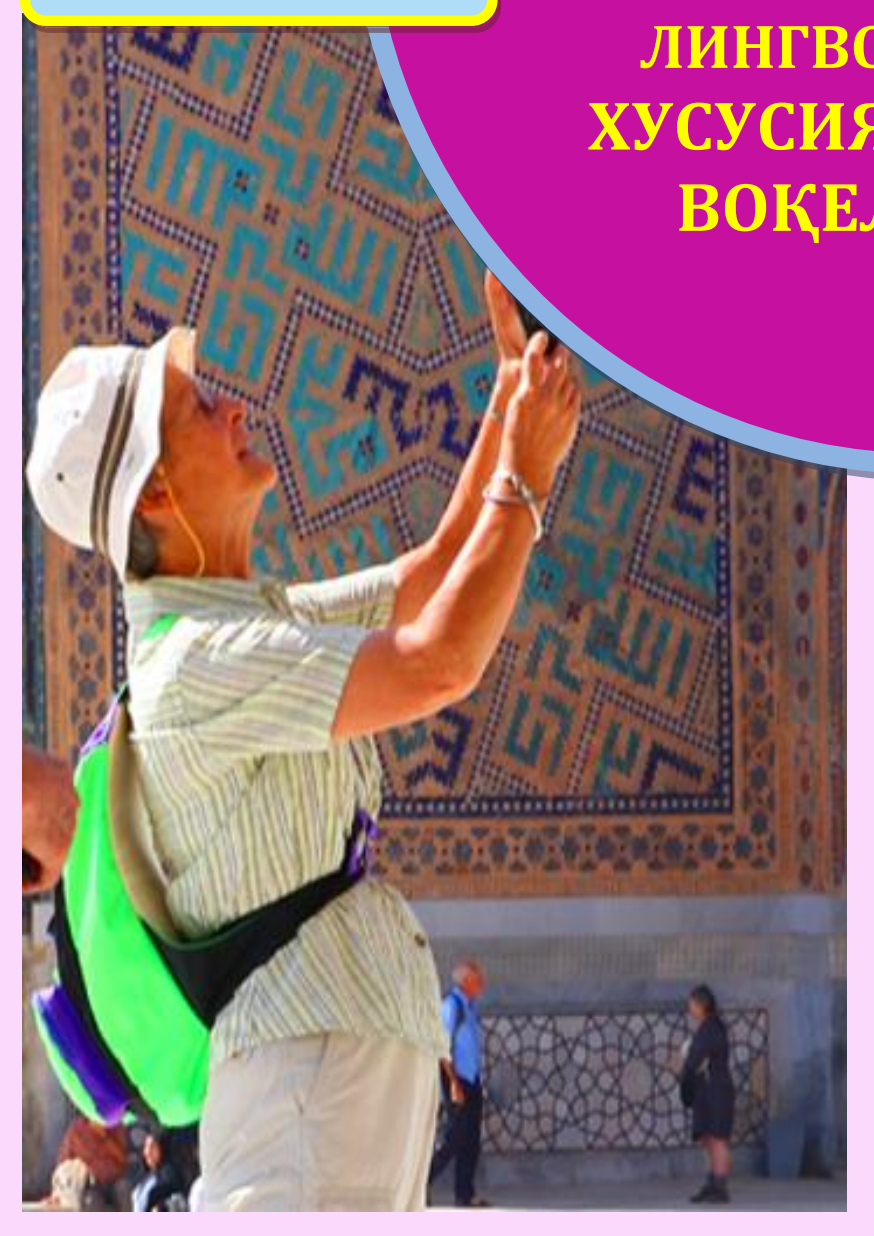

МУЛОҚОТ ЖАРАЁНИДА

ЛИНГВОМАДАНИЙ

ХУСУСИЯТЛАРНИНГ

ВОҚЕЛАНИШИ

\section{СЕКЦИЯ}

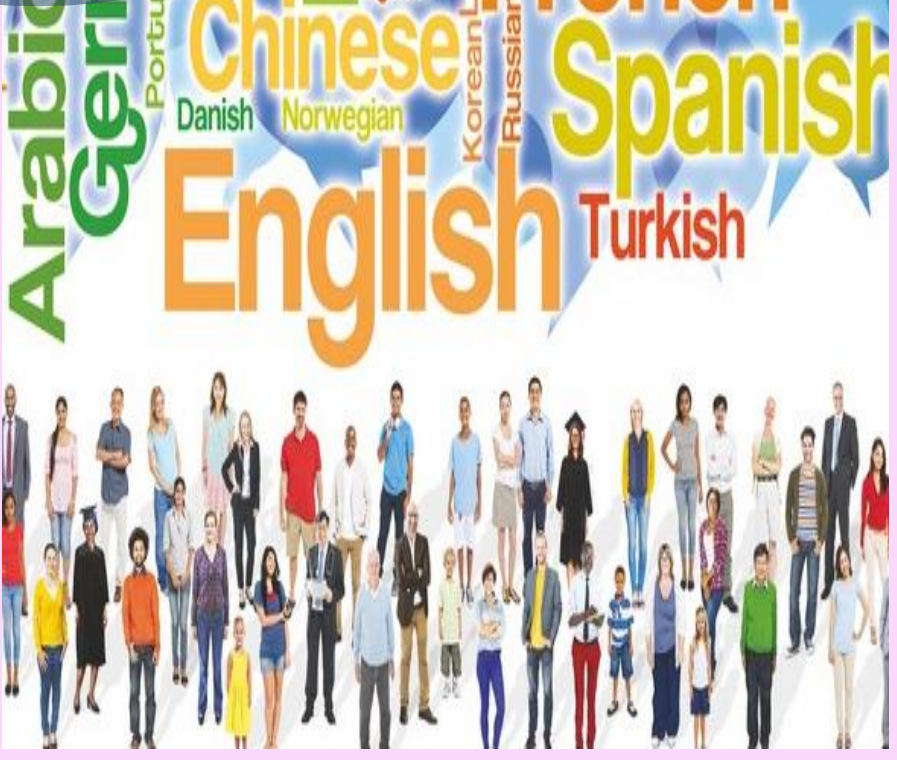


PARTICIPANTS :

1. Сафбаров Шахриёр Сафарович д.g.н., профессор (СамГИИЯ)

2. Li Didi The Confucius Institute at Samarkand State Institute of Foreign Languages

3. Peng Xing Ge teacher of SamSIFL

4. Hamdamova Charos master of SamSIFL

5. Абдиев Муродқосим Болбекович СамдУ профессори, ф.фб.д.

6. Жўраев Шахриёр Ибодуллаевич Самду ўқитувчиси, PhD

7. Киселёв Дмитрий Анатольевич д.g.н., доцент СамГИИЯ

8. Бегматов Мухтор Бегматович СамдЧТИ доценти

9. Тоирова Дилфуза Файзуллаевна д.ф.н (PhD) дочент, СФ ТУИТ

10. Чупонов Отаназар Отаджанович д.ф.н., доцент, Ургенчский государственный университет

11. Саиджанова Светлана Арслановна Магистрант, УрГУ

12. Шерматов Акрам СамдЧТИ доценти

13. Нишонов Патхиддин ЎздЖТУ доценти

14. Бўриева Наргиза Кўчқаровна жДПИ мустақил изланувчиси

15. Абдурахманов Сирожсидин Муминкулович СамДУ ўкитувчиси

16. Атауллаева Дилфуза Азизовна cm.npen. СамГИИя

17. Ахадова Гузал СамДАҚИ ўқитувчиси

18. Бегматов Кувончбек Мухторович Самарқанд давлат чет тиллар институти ўқитувчиси

19. Юсупова Мухаббат Собировна преподаватель СамГиия

20. Искандарова Мавлуда А. Қодирий номидаги ижод мактаби ўқит.

21. Ali Kaljanov アリ・カラジャノフ 博士課程

\section{ИШТИРОКЧИЛАР:}

22. Doliyeva Laylo Buriboyevna Sam. Davlat Chet Tillar Instituti o'qituvch.

23. Мамасолиев Икром Сам. давлат чет тиллар институти ўқитувч.

24. Мусинова ЗебоТурабовна Ст. Преп., СамГИия

25. Мухтарова Шахноза Файзуллаевна Преп. СамГИия

Рахимов Мирзали Раббимович

26. Сам ДУ ўқитувчиси

27. Сабирова Гулчехра Абдунабиевна $\check{У}_{3}$ Д Ж Т У ўқитувчиси

28. Саидакбарова Саодат Пархаджановна Шарқшунослик Университети муст.тадқиқотчи

29. Tursunova Mavluda Erkinovna TIQXMMI Buxoro filiali o'qituvchisi

30. Shukurova Ra'no Akmalovna SamDCHTI katta o'qituvchisi

31. Jabborova Xabiba Quvondiqovna SamDCHTI katta o'qituvchisi

32. Ходжаева Гулшод Бахадировна Ур Д У ўқитувчиси

33. Fayzullayev Xurshid Samarqand davlat chet tillar instituti talabasi

34. Мардиев Бегали СамдУ ўқитувчиси

35. Aliyeva Gulzoda Tulqinovna SamDCHTI o'qituvchisi

36. Aliyeva Nargiza Tulqinovna Samarqand viloyat Oqdaryo tuman 38-maktab o'qituvchisi

37. Кўчқорова Садоқат Тошпулатовна СамДЧТИ докторанти

38. Сабирова Гулчехра Абдунабиевна Ўз Д Ж Т У ўқитувчиси

39. Atamuradova Mavzuna Usmonovna Samarqand davlat chet tillar instituti talabasi

40 Mirzahmedov Sirojiddin Rahmatulla o 'g'li O'zbekiston davlat jahon tillari universiteti magistranti

41. To'rayeva Maftuna Akbar qizi Samarqand davlat chet tillar instituti magistr talabasi

42. Abdumurodova Makhfuza Dilmurodovna Master de l'institut des langues étrangères de Samarcande 


\section{ТИПЫ МЕТАФОРЫ ПО РАЗНОВИДНОСТЯМ ОСНОВАНИЯ ДЛЯ СРАВНЕНИЯ}

\section{Сафаров Шахриёр Сафарович д.ф.н., профессор (СамГИия)}

Annotation: The metaphorical image can be considered in various perspectives, including semantic, stylistic, and cognitive ones. This article identifies and analyzes two types of the phenomenon: relation metaphor and quality metaphor. The author identifies and describes the criteria for their differentiation, semantic structure and differences in stylistic terms.
Key words: metaphoric image, quality metaphor, relation metaphor, basis for comparison, descriptive and relative semes.

Семантическая эквивалентность темы и образного средства в метафоре бывает двух родов в зависимости от того, какое сходство наблюдается между сопоставляемыми вещами: качественное или относительное.

Как известно, качества, свойства и отношения рассматриваются как соотносительные и определяются друг через друга. Центральной категорией является категория вещи. Причем, вещь понимается не эктенсиально, т.е. не как физическое тело, предмет, а интенсиально, как система свойств. Свойство - это рефлектированное качество, т.е. качество, проявляемое вещью в ее соотношении с другими вещами. Отношение, соответственно, может рассматриваться как свойство, характеризующее две или более вещи. Различие между отношением и свойством заключается в том, что отношение может рассматриваться в абстракции от вещей, между которыми оно существует, в то время как свойство нельзя абстрагировать от определенности вещи.

Качественные и относительные признаки, становясь основанием для сравнения, задают различия между двумя типами метафоры:

1) метафора, в которой основанием для сравнения служит качественное сходство денотата темы и денотата качественного образного средства;

2) метафора, основанная на сходстве относительного свойства темы и образного средства в целом или на сходстве отношения, в котором находятся элементы темы и элементы образного средства. Сравните:

(1) The ground beneath the palm trees of Soohoo was littered with a mintage of shining silver splashed with puddles of mercury. They rolled through a continuous flickering of light and dark (A. Huxley).

Основанием для сравнения отраженного лунного света с разбросанными серебряными монетами и лужицами ртути являются чувственно воспринимаемые качества: 1) форма: маленькие просветы, отражения света на земле - маленькие монеты (mintage), лужицы (puddles); 2) цвет: блеск серебристого лунного света - блестящие серебряные монеты (shining silver), серебристость и переливчатость ртути (mercury); 3) общий вид: мелькание множества лунных бликов - беспорядочная разбросанность монет (littered with); расплесканные капельки ртути (splashed with).

(2) The wind had blown off, leaving a loud, bright night, with wings beating in the trees and a persistent organ sound as the full bellows of the earth blew the frogs full of life (S. Fitzgerald).

В этом случае исходной точкой для метафоры является качественное сходство ночных звуков, ощутимость ночной жизни земли. В эту общность качеств вовлекаются его носители - земля и орган, но дальнейшее развитие метафоры идет за счет сходства целого, элементы же темы и образного средства соотносятся друг с другом не непосредственно, а через их отношение друг к другу и к целому. Frogs здесь замещает органные трубки, потому что они звучат, т.е. по функции; the full bellows of the earth - 
животворящие силы земли, они наполняют все существа жизнью, как меха наполняют орган звуком.

Как видно, в этой метафоре существенна не тождественность элементов темы и образного средства, а тождественность отношения между ними - они являются аргументами при многоместном предикате и не могут обладать никаким сходством до вступления в эти отношения.

Разделение на метафору качества и метафору отношения не абсолютно. Дело в том, что само понятие "основание для сравнения" относительно, как относительны и взаимопереходящи категории вещи, свойства и отношения.

Рассмотрим относительность основания для сравнения на следующем примере:

(3) Hamlet is his own termite, and from a tower has eaten himself down to a heap of sawdust (A. Huxley).

Образ вводится утверждением: Hamlet is his own termite. По отношению к начальному равенству остальная часть фразы представляет собой основание для сравнения - развернутое обоснование того свойства, что делает Гамлета "термитом". В то же время каждое из слов - from a tower, has eaten .. down, to a heap of sawdust - есть образное средство по отношению к разным аспектам темы с собственным основанием. Глагольная метафора has eaten himself down может быть интерпретирована как "diminished his moral powers by doubting", общность двух процессов - в разрушительности их воздействия на объект. A tower, a heap of sawdust обозначают начальную и конечную стадии морального саморазрушения Гамлета-термита по контрастивным признакам "величие" и "ничтожность". Возвратность глагола has eaten himself down, формально объединяющая части темы и образного средства в единую синтаксическую структуру, является также содержательным моментом для метафоры - распространением определения his own, мотивирующего образное средство. Так вещь (характер Гамлета как система свойств) разлагается в метафоре на отношение. Свойства, характеризующие Гамлета, субстантированы как предметы, вовлеченные в это отношение.

Таким образом, одно и то же слово в разных отношениях может быть как образным средством, так и основанием для сравнения. Соответственно одно и то же слово с разных точек зрения может быть носителем как метафоры качества, так и метафоры отношения.

Указанные типы метафоры отличаются по своим частеречным показателям. Так, например, субстанциональной метафоре объекты сопоставляются по общим качественным признакам. В семантике принято различать два вида сем - описательные и относительные. Описательные семы отражают так называемые собственные признаки явлений, данные как качественная определенность; относительные семы отражают признаки явления, проявляющиеся в его связях с другими явлениями действительности. Два вида метафоры вовлекают в сравнение разные виды сем: в метафоре качества актуализируются описательные семы, в метафоре отношения относительные семы.

В метафорах, выраженных словами - обозначениями признаков, два действия, состояния или качества, сопоставляются по общим характеристикам, т.е. основанием для сравнения являются признаки признаков. В то же время эти слова обозначают признаки вещей, т.е. признаки первого порядка, и сохраняют связь со своими носителями. Поэтому существительные, синтагматически связанные с такими метафорами и означающие носителей метафорического признака, также имплицитно метафоризируются.

Оппозиция "метафора качества - метафора отношение" семантическая в основе, релевантна и на стилистическом уровне. Два типа образов различаются по характеру экспрессивности. Экспрессивность метафоры качества - в акцентировании качества, ведущим к большей наглядности и, иногда, гиперболизации признака; экспрессивность 
метафоры отношения - в ирреальности образа, ибо в метафоре утверждается связь между вещами, не имеющими логической связи. Метафора связи часто загадочна и парадоксальна.

\section{Литература:}

1. Lakoff G. Contemporary Theory of Metaphor. In: A. Ortony (ed.). Metaphor and Thought. Cambridge: Cambridge University Press, 1993. - P. 205-251.

2. Блек М. Метафора // Теория метафора. - М.: Прогресс, 1990. - С. 153-172.

3. Опарина Е.О. Исследования метафоры в последней трети XX века// Лингвистические исследования в конце ХХ в. - М.: ИНИОН РАН, 2000. - С. 186-204.

4. Сафаров Ш.С. Семантика. - Т.: Ўзбекистон миллий энциклопедияси, 2013. 344 б.

\section{A COMPARATIVE STUDY ON SEMANTIC FEATURES OF EMOTIONAL METAPHORS IN ENGLISH AND CHINESE}

\section{Li Didi \\ The Confucius Institute at Samarkand State Institute of Foreign Languages Email: uropb1234@gmail.com}

Annotation: The article presents a comparative study of the semantic features of emotional metaphors in English and Chinese, which, with its interdisciplinary, cross-culture nature,involves linguistics,literature, sociology,psychology, history and so on. In view of the system and semantic features of English and Chinese emotional metaphors, the article attempts to examine the similarities and differences in the respect between the two languages.

\section{Key words:} emotional metaphor; semantic feature; comparative study.

Since the end of the 1980s, the study of modern semantics has exhibited multidisciplinary, interdisciplinary, multidimensional and multilevel characteristics. Cognitive linguistics is a good attempt to study language from the interaction between language and human thinking. Cognitive semantics mainly studies the formation, content and understanding of lexical meaning from the cognitive characteristics and methods of human brain. The main aspects of of cognitive semantics include categorization, schema theory, metaphor, etc. As a thinking phenomenon, metaphor is influenced by personal thinking in the process of cognizing the world. As far as thinking activities are concerned, the commonality between different nations is identical. However, because the thinking mode and thinking habits of a nation have accumulated the most core and stable factors in its national culture, reflecting the most basic characteristics of the psychological quality of its national culture, this makes the thinking modes and thinking habits of each nation different

Semantics is the embodiment of thinking, the general reflection of objective things in people's minds after being recognized, and the center of speech communication. Semantics is the center where people can exchange information and understand each other. Without semantics, there is no communication .

Due to the differences of words and language structure between Chinese and English, people have different cognition on semantic research. In many languages, there are semantic similarities and differences in emotional metaphors. The semantic comparison of sentimental metaphors in Chinese and English is an interdisciplinary and cross-cultural study, including linguistics, literature, sociology, psychology, history, and many other fields. This article intends to carry out a semantic contrast analysis of common emotional metaphors in English and Chinese from the perspective of emotional metaphor systems and the semantic features of emotional metaphors, to dig the deeper similarities and differences in emotional metaphors in English and Chinese. 


\section{II.Emotional semantics system}

When people express emotion, they often use metaphors, that is, emotional metaphors. As a cognitive tool, it promotes the evolution of vocabulary in a well-founded manner and is the key to understand the phenomenon of polysemy and semantic transfer. Metaphor uses the similarity of one thing and another to transfer the structure and characteristics of the source concept domain to the target domain. The words involved in the source concept domain are used to refer to and describe the target domain, forming a cross-domain mapping, so that the words have new meanings based on the previous meanings, and many polysemes are generated in this way[2] .

\section{Body part metaphors}

The emotional metaphors in English and Chinese have distinct national thinking differences, are closely related to human daily life, and are mostly fixed by convention. English emotional metaphors are often expressed by fixed phrases, idioms, slang, etc .; Chinese emotional metaphors are often composed of idioms, rest words, and fixed phrases. There are similarities between English and Chinese emotional metaphor systems, all involving body part metaphor, color metaphor, nature metaphor, animal and plant metaphor, and instrument metaphor, etc., but there are semantic differences in expressing emotions [4].

Human emotions such as happiness, sadness, and joy are abstract concepts in essence. In order to facilitate the expression and understanding of these emotions, people often metaphorize them. That is, to understand and express complex, abstract, or less certain concepts through specific ideas or concepts familiar to humans[3].

In emotional metaphors, body parts often become vehicles for people to express their emotions. skin,etc.

English body parts metaphors include heart, mind, head, mouth, leg, hair, tail, blood,

Example 1: We messed with the enemies' head / mind.

Example 2: My hair stood on end when I saw that terrible film.

Example 3: Her son's failure to the entrance of elimination gets under her skin.

Example 4: John likes rock music very much, for it can stir his blood.

Chinese body metaphors include the parts of heart, head, face, mouth, chest, internal organs, eyes, eyebrows, hair, beard, hands, feet, soul, etc. These parts are also commonly used to express emotions. In addition, Chinese body metaphors involve movements of body parts and are usually dynamic descriptions.

心: 心范怒放旷神怡大快人心

头：不堪回首缩头缩脑摇头晃脑

\section{目登口等口若悬河口服服口是门非}

眼 眼展金星怒的而见眼巴

魂鬼 魂牵梦索魂不附柣魂落鬼

身体 七穹生烟浑身是胆身心效瘁

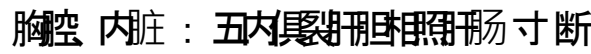

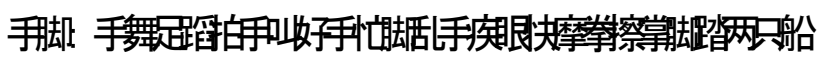

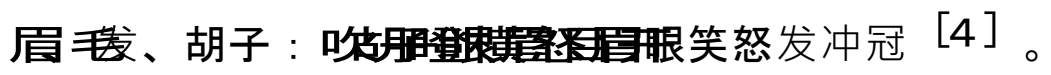

\section{Color metaphors}

There are a large number of color metaphors that express emotions in English and Chinese, which are divided into natural color metaphors and 
face metaphors. Natural colors are associative, making metaphors of natural colors metaphorical; face metaphors can also be used to express emotions. People's happiness, anger, sorrow, joy and other emotional fluctuations are usually reflected on the face, causing the face to change. For example, people's faces turn red when they are excited, agitated, and shy; their faces lose their blood and become pale when they are afraid. Therefore, both natural color metaphors and face metaphors can be used to express special emotions. Due to the differences between Chinese and Western cultures, there are great differences in color metaphors between English and Chinese.

Natural colors such as green, blue, yellow, and black are commonly used in English to express emotions. These color words have their own unique expressions, which is very different from Chinese.

English word "green "is often used to express jealousy, equivalent to jealous.

Example 1: She is green with envy.

Example 2: Tom won lottery of 5 million dollars yesterday, his neighbor, the Collins were green eyed.

English word "blue" represents emotional metaphors such as depression and sorrow.

Example 3: It was blue Monday and she just didn't feel like going back to work.

Example 4: He was quite blue over his dismissal.

Yellow is often used to describe a person's timidity and contempt, which is equivalent to cowardly.

Example 5: She is too yellow to stand up and fight.

Example 6: I always know you are yellow!

Black expresses emotions such as sadness and anger, which is equivalent to angry.

Example 7: His face is black with rage.

Example 8: Since his wife killed in the car accident last year, he has been in a black mood.

There are not many emotions in Chinese natural colors. "Grey" is an uncomfortable color and is often used to express emotions such as "disappointment" and "depression". For example: 灰心丧气、灰头土脸、心灰意懒、心灰意冷等.

\section{Natural metaphors}

Natural metaphors are divided into natural phenomenon metaphors, weather metaphors, temperature metaphors and sound metaphors. Metaphors of natural phenomena that express emotions in English include four seasons, fire and. The four seasons metaphor of English emotions mainly involves wintry and so on.

Example 1: The receptionist has a wintry manner.

Example 2:She gave a wintry smile.

There are four main metaphors of emotion in Chinese: 春风满面、春风得意、满面春风、 秋波等。

Example 3 ：他年满三十, 就被提拔为处级干部，正是春风得意之时。

Example 4：看他那一副春风满面的样子, 看来一定有什么好事

Example 5：眼色暗相钩, 秋波横欲流。

The metaphor of "fire" in English includes fire, flame, blaze, etc. These words are mostly related to intense emotions such as "excitement" and "anger".

Example 6 : After reading Steinbeck, Joel was fired with the ambition to become a writer.

Example 7: Her face flamed with anger.

Example 8: Mr Anderson's eyes blazed with anger.

The emotional metaphors of fire in Chinese are: 火冒三尺、火烧火燎、无明之火、火冒三 丈、动肝火等. 
Example 9 : 当自成在路上才得到报告时, 他不禁火冒三尺, 恨恨地骂了一声：“该死！'

Example 10 : 大清早, 见鬼一般, 刚爬起来, 一种无明之火就在体内缓缓燃烧, 燥热、 疼痛, 逐渐蔓延, 痛切了全身。

English emotional metaphors expressing "气" mainly involve air, etc.

Example 11: Mary won the first prize in the oral competition yesterday, she was floating on air.

Example 12: What he said really took the air of my balloon.

The metaphor of "气" in Chinese mainly includes 生气、火气、气呼呼、气鼓鼓、出气筒 、心里有气、拿人撒气等。

In addition, Chinese often use natural metaphors such as light and waves to express emotions. Commonly used words are: 满脸红光、心潮澎湃、红光满面。

The metaphor of heaven and earth in English is often expressed by fog, cluster, window, breed, etc.

Example 13: Sorry, what did you say? My mind is in a fog at the moment.

Example 14: The little girl was on a cloud after winning the swimming competition.

Example 15: His breezy manner made him popular with other workers but not with his employer.

In Chinese, weather metaphors are: 风霜雨雪、雾云雷电、阴晴、冷暖、满面春风、冷若 冰霜、凄风苦雨、大发雷霆等。

English temperature metaphor is often used to express emotions, because cold and heat are closely related to emotions. Cold often used to express "sadness", "fear", and hot is used to express "anger", "shame", and so on.

In Chinese, the temperature metaphor is divided into four categories, including "hot", "warm", "cold", "cool", "joy is warm", "anger is hot", "sad and fear is cold".

\section{Plant and animal metaphors}

Animal-related emotional metaphors in English mainly involve goat, goose, bug, blossom, etc.

Example 1:I will tell you another thing that really got my goat.

Example 2: I get goose-bumpy at the thought of that giant boa at the zoo.

Example 3: It really bugs me when the car behind me drives too close.

Plant-related emotional metaphors in English include blossom, treat, etc.

Example 4: Peter has really blossomed out in his new school.

The metaphor of emotional metaphors related to animals in Chinese involves "bird", "ant", "tiger", "snake", "crane" and so on.

Plant-related emotional metaphors in Chinese include "flower" and "grass".

III. Semantic Features of Emotional Metaphors in English and Chinese

\section{Metaphorical of emotional metaphor}

The metaphor of emotional metaphors is often associated with some things that easy to reveal and easy

to change. Human organs and parts are the carriers of emotion, and body metaphor is the most common emotional metaphor. The body includes the heart, the head, the brain, the mouth, the head, the feet, and the blood [4] .

The heart in English and Chinese is often used to express people's happiness, anger, sorrow, and joy.

Example1: The story gladdened the little girl's heart very much.

Example 2: Uncle Tom's tragic experiences touched our hearts with sorrow.

Because the temperature is high or low, people often think of emotions. In English and Chinese metaphors, warming and cooling are often used to indicate emotional changes. 
Warming up means get warm or warmer, cooling down means get cold or colder or calm down cold means "fear", boil means "furious", and hot means "angry"[4].

Example 3:The professor warmed up the students with a few jokes.

Example 4: Don't speak to her until she is cooled down.

Example 5: What happened to her yesterday really made her blood run cold.

\section{The exaggeration of emotional metaphorical}

Emotional metaphors are exaggerated. Emotional metaphors in English and Chinese often use exaggerated words and large numbers of words to express their exaggeration.

Example 1:他气得肺都炸了。

\section{Example 2: 这真是喜从天降啊！}

Example 3: At last her anger exploded.

Example 4: The bottom dropped out of John's word.

\section{The vividness of emotional metaphors}

In addition to being metaphorical and exaggerated, emotional metaphors in English and Chinese are also vivid. Human emotions are generally common, and many languages often use similar emotional metaphors to express their vividness[4]. "Fire", "red", and "purple" in English and Chinese can all serve as a metaphor for "anger" and appear vivid.

Example 1:The boss's insincere apology just added fuel to the fire.

Example 2: Her face was red with anger.

Example 3: He went purple in the face.

Some metaphors express different emotions due to differences in historical, regional, custom, and language expressions. Their metaphors use things that are unique or customary to their own nation, and have their own unique associations[6]. For example, when expressing the feelings of "tension" and "urgency", the English language is "like a cat on hot bricks", while Chinese uses "the ant on a hot pot".

Example 4: Last autumn, my daughter was like a cat on hot bricks before her driving test.

\section{Conclusion}

In cognitive semantics, emotional metaphor is a cognitive activity in which humans use their experience in one field to explain or understand the experience in another field [1] . As a language and cognitive phenomenon, emotional metaphor has greatly enriched the language itself and has become an indispensable part of people's daily life. Emotional metaphors are abundant in English and Chinese, and they have similarities and differences. Understanding of emotional metaphors is conducive to our deep grasp of English and Chinese metaphors [7] Because emotional metaphors are closely related to human daily life and are affected by culture, if the emotional metaphors in the target language are different from the emotional metaphors in the mother tongue, students can't grasp it correctly, they can only understand it and use it inappropriately. Teachers should consciously teach the customary emotional metaphors in the target language in English teaching, which will help students correctly understand the metaphorical meaning of vocabulary, and will greatly help improve English language teaching.

\section{References :}

[1] Shu Dingfang, Modern Semantics[M].Shanghai: Shanghai Foreign Language Education Press, 2000 [2] Lakoff Geoge, Mark Johnson, Metaphors we live by [M]. Chicago: The University of Chicago Press, 1980

[3] Ortony A. Metaphor and thought [M]. Cambridge:Cambridge University Press, 1993

[4] Wang Fengxin.English - Chinese comparative semantics[M] ,Beijing: Foreign Language Press, 2001

[5] Leech G. Semantics , the study of meaning [M]. Harmondsworth: Pengui Books Ltd, 1981

[6] Langacher Ronald W. Foundations of cognitive grammar [M].Beijing: Peking University of Press, 2004

Wang Yan, Semantic theory and language teaching [M]. Shsnaghai: Shanghai Foreign Language Education Press, 2001 


\section{XITOY TILIDA MUSTAQIL SO`Z TURKUMLARI REDUPLIKATSIYASINING TO`LDIRUVCHI VAZIFASIDA KELISHI}

\section{Peng Xing Ge \\ teacher of SamSIFL \\ Email:452161501@qq.com \\ Hamdamova Charos master of SamSIFL \\ Email:hamdamovac@gmail.com}

Annotation: In this article discusses the difference of the construction of the complementary part of speech in Chinese differs in part from the construction of the complementary part of speech in Uzbek. These differences are clearly demonstrated using examples in two languages. In this article not only word groups, but also specific information about their repetitive appearance are given. In this research work mainly nouns, adjectives and verb phrases are studied.
Key Words:

morphology, noun, adjective, verb, reduplication, object, direct object, indirect object.

Mustaqil so`z turkumlari xitoy tilida 实词 shici deb atalib, u, asosan, ot, fe`l, sifat va hisob so`z kabilarni o`z ichiga oladi. Xitoy tili grammatikasini o`rganish jarayonida mustaqil so`z turkumlari xitoy tilining muhim jihati hisoblanmasa-da, ammo u ham maxsus e`tabor talab qiladi. Ot va olmosh gap tarkibida asosan, ega va to ldiruvchi, ayrim hollarda esa aniqlovchi bo'lib keladi. Vaqtga ishora qiluvchi otlar hol va kesim vazifasida keladigan hollar ham uchraydi. Fe'l va sifat so`z turkumlari gap tarkibida ko`pincha kesim, ayrim hollarda esa hol va aniqlovchi bo`lib kelishini kuzatsak, aksincha hisob so`zlar gap tarkibida, asosan, aniqlovchi va hol vazifasida kelishi kuzatiladi.

Mazkur tadqiqod ishida xitoy tilining ot, fe`l, sifat so`z turkumlarini qisqacha tanishtirib o`tar ekanmiz, shu bilan birga ushbu so`z turkumlarining reduplikatsiya (ikkilanish) jarayonlari tildan foydalanish va muloqot jarayonida turli mazmun kasb etgani va turli vazifalarni bajargani bois, ular to`g`risida qisqacha to`xtalib o`tamiz. O`rganuvchilar chuqurroq ma`lumotga ega bo'lishlari maqsadida maqola yuzasidan quyidagi xulosaga kelishni lozim topdik.

Ot so`z turkumi narsa - buyum yoki biror shaxsga ishora qiladi. Xitoy tilida ot so`z turkumining bir necha xil ko`rinishlari mavjud bo 'lib, oddiyroq qilib aytganda, aniq va mavhum (abstrak) ma`nolarni bildiruvchi otlar deb nomlanuvchi ikki turga ajratish mumkin, va ushbu ikki tur otlarning o`zi yana kichik guuhlarga ajratilishini ta`kidlab o`tish joiz. [2, 32 - b.] O`rganuvchilarga qiyinchilik tug`dirmaslik maqsadida quyida biz otning ikki katta turi haqida ma`lumot beramiz:

Aniq ma`noni bildiruvchi otlar.

Ushbu tur otlar, asosan, biz ko`zimiz yordamida ko’rish, qo limiz bilan paypaslab sezish, quloqlarimiz yordamida esa eshitish imkoniga ega bo 'lgan shaxs yoki narsa - buyum kabilarni o`z ichiga olib, ular xitoy tili otlarining asosiy qismini tashkil qiladi. Masalan:

(1) Shaxs yoki narsa - buyumga ishora qiluvchi otlar. Ushbu tur otlarining umumiy soni juda ham ko`p bo`lib, asosan, quyidagilarni o`z ichiga oladi:

Ota - ona, aka - uka, opa - singil, o`qituvchi - murabbiy, sinfdosh, do`st, Quyosh, oy, yulduz, yer shari, mars, somon yo li.

(2) Hayvon va o`simliklarga ishora qiluvchi otlar. Ushbu guruh otlarining ham umumiy soni talaygina. Masalan:

Cho`chqa, sigir, ot, qo`y, qush, baliq, quyon, tovuq, mushuk. 
(3) Yo`nalish va joyga ishora qiluvchi otlar. Ushbu tur otlar o`z ichiga juda ko`p otlarni qamrab olganligi bois, ularning sonini cheksiz deyishimiz ham mumkin. Ularga misol qilib quyidagilarni keltiramiz:

Yuqori, quyi, o’ng, chap, ichkari, tashqari, sharq, orqa,

Pekin, Xitoy devori, “Osmon ibodatxonasi”, Parij, Nyu - York, Seul

(4) Sana va vaqtlarga ishora qiluvchi otlar. Ushbu tur otlarning umumiy soni ham xuddi yuqoridagi tur otlarning soni singari ko’p. Ammo ushbu tur otlarning o'ziga yarasha xususiyati shundaki, ushbu tur otlarni ko`rish, paypaslash, umuman olganda, sezgi a`zolari yordamida sezishning imkoni yo`q. Masalan, kun, oy, hafta, soat, bugun, hozir, kelgusida, yangi yil, "Bahor bayrami", qish, bahor, qishki ta`til, yozgi ta`til.

1. Mavhum ma`no anglatuvchi otlar

Ushbu tur otlar ko`rish va paypaslash mumkin bo'lmagan, insonning sezgi a`zolari yordamida his qilish mumkin bo'lgan otlardir. Ushbu tur otlar ham katta guruhni o`z ichiga oladi. Masalan:

0`y, hayol, ma`no, mazmun, mantiq, psixika.

2. Ot so`z turkumining grammatik xususiyatlari

Ot so`z turkumining grammatik xususiyatlari qisqacha quyidagilarni o`z ichiga oladi deyish mumkin:

(1) Ot gap tarkibida, asosan, ega, to`ldiruvchi va aniqlovchi vazifasida kelishi mumkin;

(2) Ot gapda to`g`ridan - to`g`ri hisob so`zlarni qabul qilib, sifat so`z turkumi bilan bog lanib, to`ldiruvchili birikma hosil qilishi mumkin, ammo ot gapda ravishli birikma yasamaydi va ravish so`z turkumi ot oldidan kelmaydi. [2, 32 - b.]

(3) Odatda, ot so`z turkumi ikkilanish xususiyatiga ega emas, ayrim hollarda ikkilanish (reduplikatsiya) jarayoniga uchragan otlar hisob so`z xarakteriga ega bo ladi hamda universallikni ifodalaydi.

(4) Shaxslarga ishora qiluvchi otlardan so`ng qo`shilgan ko`plik qo`shimchasi otlarga ko`plik soni vazifasini yuklaydi. Bunday hollarda ko`plik qo`shimchasini olgan otlar oldidan son - sanoqni bildiruvchi hisob so`zlar qo`shilmaydi.

(5) O`rin - joyga ishora qiluvchi so`zlar yoki so`z birikmalari gap tarkibida ko pincha ravish vazifasini bajaradi.

3. Ot so`z turkumining reduplikatsiyasi va uning mohiyati

Ot so`z turkumining ikkilanish jarayoni xitoy tilida kam uchraydi, chunki ayrim otlar odatda, ikkilanish xususiyatiga ega emas, faqatgina kamchilik hisob so`z xususiyatiga ega bo 'lgan bir bo `g inli otlar hamda alohida xarakterli xususiyatga ega bo'lgan ikki bo`g inli otlar ikkilanish xususiyatiga ega. Otlar reduplikatsiya jarayoniga uchragach, ularning ma nosi xuddi hisob so`zlarniki kabi bo`ladi, ya`ni har bir yoki umumiy ma`nolariga ega bo ladi. Ahamiyatli jihati shundaki, ikkilanish xususiyatiga ega bo'lgan kam sonli otlar, odatda, vaqt, shaxs, o`rin joyga ishora qiladi. Ikki bo`g`inli otlarning ikkilanish formasi "AABB" shaklida bo ladi.

Xitoy tilida otlarning ikkilanish jarayonini quyidagi formula orqali tushuntirish mumkin:

Bir bo`g inli otlar AA

Ikki bo`g inli otlar AABB

Ushbu formulani quyidagi misollar orqali tushuntirib o`tamiz.

日日riri - ushbu so`z xitoy tilidagi 日i quyosh, kun so`zining ikkilanish shakli bo`lib, uning ikkilanishi bilan yangi mazmundagi so`z kelib chiqadi va reduplikatsiyaga uchragan bu so`z har kuni deb tarjima qilinadi. Umuman olganda, bu jarayonga uchraydigan har bir so`z ikkilanishdan keyin har, har bir ma`nolarini oladi. Masalan, 天大tiantian - 天ian kun, bu so`z ham har kun deb tarjima qilinadi. [1, 23 - b.]

月yue oy - 月月yueyue har oy,

رren kishi, odam - Mrenren har bir kishi,

家jia uy, oila - 家家jiajia har bir oila. 
Yana shunday otlar borki, yuqoridagi misollardan farqli o`laroq, ular reduplikatsiya jarayonidan keyinhar yoki har bir ma`nosidan tashqari, borgan sari, ...dan ...ga ma`nosiga ham ega bo`ladi. Bunday otlarga misol qilib, yil so`zini keltiramiz:

年ian yil - 年年niannian har yili, yildan yilga,

辈 bei avlod - 辈辈 beibei - avloddan avlodga.

E`tiborli jihati shundaki, otlarning ikkilanish jarayonida yana shunday so`zlar ham borki, ular ikkilangandan so`ng, ayrim hollarda ma`nosini o`zgartiradi. Ularga misol qilib, quyidagilarni keltiramiz:

祖 yoki borgan sari emas, aksincha avlod, nasl ma`nolarini oladi.

日夜riye kecha - kunduz - 日日夜夜riri yeye kecha - yu kunduz (har doim) ma`nosida.

Ayrim katta - kichik, yuqori - quyi, uzun - kalta singari qarama - qarshi ma`noli so`zlardan tashkil topgan juft so`zlar ham borki, ularning reduplikatsiyasi ham AABB shakliga asoslanadi. Ularning ma`nolari ham xuddi yuqoridagi singari universallikni ifodalaydi. Ushbu

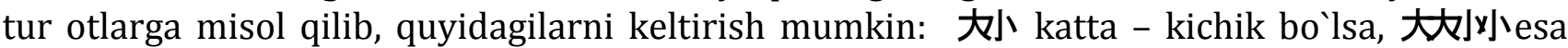
barcha o`lcham ma`nosini bildiradi. 高氐yuqori - past bo`lsa, 高高氐氐sa har qanday sharoitda demakdir. Shuningdek, ushbu quyidagi otlar ushbu turga misol bo'ladi: 强强弱弱, 长长短短,

早早晚晚, 粗粗细细, 高高矮矮, 是是非, 快㶧曼曼 多多少少

Ikki bo`g`inli otlar ikkilangach, gap tarkibida ega, aniqlovchi va hatto hol ham bo`lib kelishi mumkin. Masalan, 北京效经家家通电话, 村村装了自来水Beijing jiaooqu yijing jiajia tongle dianhua, cuncun zhuangle zilaishui Pekin atrofidagi uylarga (har bir uyga) telefonlar o`rnatilib, qishloqlarga (qishloqlarga) vodoprovod suvi yetkazildi. E`tibor bering yuqoridagi misolda 家家 hamda 柎 (uy va qishloq) otlari ikkilanib kelyapti, ular qoidaga asosan, gap tarkibida har bir ma`nosida kelgan. Otlar ikkilangandagi universallik xususiyati quyidagi misolga ham tegishli: 你看 学校里方方面面的事聙淂我喿心 难啊! ni kan, xuexiao li fangfang mianmian de shiqing dou dei wo caoxin. Nan a! Qara, maktabdagi har bir ishga men qayg urishim kerak. Oson emas, axir misolida reduplikatsiyaga uchragan 方面 oti ikkilanib har tarafdan, har tomondan ma`nosini yo`qotib har bir ma`nosida kelgan.

Xulosa o`rnida shuni ta`kidlash joizki, xuddi xitoy tilidagi singari o’zbek tilida ham to 'ldiruvchi gap bo`lagi o`zining murakkabligi hamda o`rganilish ob`yektining kengligi bilan bir - biridan deyarli farq qilmaydi. Ammo ahamiyatli jihati shundaki, xuddi xitoy tilidagidek o`zbek tilida ikkilangan so`zlarning gap tarkibida qaysi gap bo`lagi vazifasida kelishi kelishik qo`shimchalari yordamida yaqqol namoyon bo`ladi.

\section{Adabiyotlar:}

1. M.Qodirov, H. Ne`matov, Ona tili, 8- sinflar uchun darslik, Cho`lpon nomidagi nashriyot - matbaa ijodiy uyi, Toshkent 2014.

2. 朱庆明, 现代汉语实用语法分析（第二版）上册。清华大学出版社 2012 年

3. 朱庆明, 现代汉语实用语法分析（第二版）下册。清华大学出版社 2012 年

4. www.baidu.com 


\title{
ЎХШАТИШ АСОСИДА ХОСИЛ ҚИЛИНГАН ЛЕКСЕМАЛАРНИНГ ЛИНГВОКУЛЬТУРОЛОГИК ХУСУСИЯТЛАРИ
}

\section{Абдиев Муродқосим Болбекович СамдУ профессори, филология фанлари доктори Email:murodkasim63@ mail.ru}

\section{Жўраев Шахриёр Ибодуллаевич СамдУ ўқитувчиси, PhD Email:shahriyor@gmail.com.}

\begin{abstract}
Annotation:This article discusses the lingvoculturological properties of textile terms formed on the basis of analogy. In particular, the work describes the authors' observations on the creation of a linguistic picture of the world from a human point of view of the field terms.

Key Words: hyperbole, literature, language, beautiful lingvoculturology, similitude, linguistic landscape, national crafts, textiles, carpets, embroidery, terminology, field and so on.
\end{abstract}

Маълумки, инсоннинг дунёни англашида метфоранинг мухим бир тармоғи бўлган ўхшатишнинг ўрни мухимдир. Икки ва ундан ортиқ предмет ёки тушунчани ўхшаш ва фарқли жихатларини аниқлаш мақсадида дунёнинг англашнинг энг кўп тарқалган мантиқий усулларидан бири сифатида инсон хаётининг барча сохаларида кузатилади. Бу бехад мантиқий категория, табиийки, тилда ўз аксини топади[1., 96].

Ўхшатиш масаласига бўлган қизиқиш ва уни ўрганиш қадимдан турли соха вакиллари жумладан, тилшуносларнинг эътиборини ўзига жалб этиб келганлиги тарихдан маълум. Бу борада ўзбек тилшунослигида М. Миртожиев, А. Рустамов, М. Мукаррамов, Н. Махмудов, Д. Худойберганова, Н. Қобулжонова, Ш. Махмараимова сингари олимларнинг бир қатор тадқиқотлари яратилган.

Маданиятимизнинг бир бўлаги бўлган миллий хунармандчилик хам дунё лисоний манзараси тасвири мужассамланганлиги билан мухим ахамият касб этади. Шундай экан, миллий хунармандчиликка хос лисоний манзарани ўхшатишлар мисолида тадқиқ этиш хам лингвокультурология фани учун ўта долзарб масалалардан бири хисобланади.

Биз ушбу ишимизда тўқимачилик сохалари доирасида ўхшатиш асосида хосил бўлган терминларнинг баъзи бир лингвокултурологик хусусиятларига тўхталишга харакат қиламиз.

Одатда терминлар хосил қилишда аффиксация, композицион хамда бирор тушунчани ифодалаш мақсадида унга ўхшатилган нарса асосида ўхшатишлардан кенг фойдаланилади. Биргина тўқимачилик махсулотлари сифатида гилам, поёндоз, олача, сочиқ, кашта, чойшаб кабилар тайёрланади. Бу нарса-предметлар номига гул, кашта, нусха, нақш, усул, безак каби терминэлементлар қўшиб ишлатилади: иккигулли гилам, чойшаб каштаси , сочиқ гули, ёстиқ гули кабилар.

Шу билан бирга бу нарса-предметлар номларига қайд этилган лексемаларни биринчи тип изофа воситасида ифодалаш орқали хам махсус терминларнинг юзага келтирилганлигини қуйидаги мисоллар билан тасдиқлаш мумкин. Бундай луғавий бирликлар, хунармандликнинг каштачилик, гиламчилик каби сохаларида кўпроқ учрайди: аноргул (каштачиликда), илон изи (ўймакорлик, каштачилик, кошинкорлик, кулоллик каби сохаларда), чашми булбул (каштачилик, йўрмадўзлик сохаларида), балиқкўз (гиламчилик, пичоқчилик), туя-кўз (холвапазлик), самоваргул (каштачилик), тариқгул (каштачилик, гиламчилик, кулоллик), бовирсоқгул (бўғирсоқ) гул (гиламчилик), осагул (каштачилик ва гиламчилик), карсангул//тоғорагул 
(гиламчилик, каштачилик), тол барги (каштачилик), иттовон (гиламчилик), пичок учи (гиламчилик) кабилар.

Топоним ва этнонимларга хам хунармандлик терминларини қўшиш билан терминлар хосил қилинади: ургути нусха, бухорча усул, самарқандча безак, қозоқи гилам, жухути сандиқ, туркмани гилам, ўрис кашта, татарча сандиқ, каттақўрғони сандиқ, панжакенти этик, бахмали гилам, ўзбеки халат кабилар.

Бошқа тилларда бўлганидек, ўзбек тилида хам лексеманинг маъносини кўчириш, яъни, сўзга «янги хаёт» бағишлаш азалий усуллардан бири эканлигини тўқимачиликка доир материаллар тасдиқлай олади. Маънони кўчиришнинг ўхшатиш йўли билан термин хосил қилиш хам фаол эканлигини кўриш мумкин.

С.И.Иброхимов Фарғона водийси вакиллари нутқида ишлатиб келинган луғавий бирликлар хақида махсус монография яратди ва докторлик диссертациясини химоя қилди. Бу ишларда шу сохага доир сез/терминларнинг ясалиши хусусида хам батафсил тўхтаб ўтилган. Булар қуйидагилардан иборат: «1. Ўхшатиш принципи. 2. Хослаш принципи. 3. Нисбат бериш принципи. 4. Материалига кўра номлаш принципи. 5. Вазифасига кўра номлаш принципи. 6. Ўринга кўра номлаш принципи. 7. Ташқи шакл ва холатига кўра номлаш принципи. 8. Овозига кўра ном бериш принципи. 9. Ўлчовига кўра ном бериш принципи. 10. Процесс, харакат эътибори билан ном бериш принципи ва хоказо...» [2.,157-168].

Муаллифнинг фикрига тўлиқ қўшилиб айтмоқчимизки, касб-хунар терминларининг юзага келишида бошқача лисоний омиллардан хам фойдаланиб келинар экан. Буни тўқимачиликбилан шуғулланувчи шахслар нутқида хам ишлатилиб келинаётган луғавий бирликлар мисолида кўриш мумкин. Тўғри, бу таснифда асосан металлсозликка доир терминлар хақида гап кетган. Бироқ касб-хунармандликнинг яна бошқа турлари хам нихоятда кўпки, улар нафақат оғзаки нутқда, балки ёзма нутқда хам ишлатиб келинмоқда. Семантик маъноси кўчирилган касб-хунармандликка оид терминлар шулар жумласидандир.

Мухим лисоний далиллардан бири, бошқа сохаларга оид лексемалар касбхунармандлик лексикологик тизимида муқим бўлиб қолган холлар хам учрайди: $\underline{\text { aноp }}$ ёхуд аноргул ботаник терминлардир. Айни пайтда мазкур терминлар каштачилик, кулоллик, тўқимачилик, гиламчилик, нақшинкорлик каби гурухларда «анор меваси акс эттирилган нақш» маъносида баб-баравар қўлланаверади.

Тўқимачиликнинг турли-туман сохаларида ишлатилаётган, бироқ бошқа-бошқа сохаларга алоқадор луғавий бирликлар жумласига яна қуйидагиларни далил сифатида келтирамиз: Бодом-каштачилик, ўймакорлик, нақшинкорлик, тўқимачилик, жиякчиликда; бодомча-каштачилик, кулолликда; илон изи-каштачилик, кулоллик, ўймакорликда; капалак-каштачилик, тўқимачиликда; нўхат//нахўд-каштачилик, кулолликда; от-гиламчилик, каштачиликда; сув-каштачилик, гиламчиликда.

Маълумки, Ўзбекистон ва Тожикистон водийларининг шахар ва қишлоқларида, деб ёзади О.Худоёрова, -қадимий дехқончилик маданияти марказлари мавжуд бўлиб, кишилар ўз мехнати билан сахроларни экин майдонларига, боғларга айлантирганлар ва хар ерга мехр-мухаббат, чидам билан ишлов берган, дарахтлар соя-салқинини, оромбахш манзараларни ардоқлаб келганлар. Айниқса, улар эстетик дид билан турли гуллар ўстирганлар. Ана шу гуллар, гулзор ва боғлар кашталарга (касб-хунарнинг бошқа турларига хам-М.А.,Ш.Ж.) кўчган. У юксак талант ва махорат сохиблари бўлган санъаткорлар ижодий фантазияси воситасида бахт ва шодлик келтирувчи безакларга айланган. Унда гуллар, юлдузлар, гулдасталар, новдалар, шохчалар, бутоқлар, шунингдек, табиат манзараси ва ундаги қушлар тасвири, хайвонотлар уз аксини топган[3., 32]. Эхтирос билан билдирилган бу фикрда жон бор, албатта. Хақиқатан, касбхунармандликнинг барча сохаларида юқорида айтилган ва айтилмай қолган (масалан, уй-рўзғор буюмлари, ёзувлар ва шакллар, хилма-хил предметлар ва х.) нарса- 
предметлар у ёки бу даражада ўз ифодасини топади. Натижада ўзбек тили лексикасида, хусусан, касб-хунар лексикологик системасида юзлаб тушунчаларни ифодаловчи луғавий бирликлар мажмуи таркиб топди. Лексика доирасида рўй бериб келаётган бу жараёнда ўхшатишнинг ўрни жуда каттадир.

С.Иброхимов шундай деб ёзади: «Ишлаб чиқариш терминларининг лексиксемантик тузилишининг тахлили шуни кўрсатадики, терминлар касб-хунар ахлларининг нарса ва ходисаларга уларнинг белгиларини тўғри тушуниш хамда бошқа нарса ва ходиса белгиларига ўхшатиб, қиёслаб, образли тушуниш йўли билан тузилади... Металлсозлар ўзлари ишлатадиган иш қуролларини ясаган махсулотларини нарсаларга ўхшатиб хам ишлайдилар» [2., 158-159].

С.Иброхимовнинг бу фикр-мулохазалари тўқимачилик билан шуғулланувчи шахслар лексиконига хам тўла тааллуқлидир. Соха касб эгалари билан олиб борилган сухбатлар чоғида етарли миқдорда материал тўпланди. Улар системалаштирилиб, тахлил қилиб чиқилгандан сўнг касб-хунарга оид кўплаб тушунчалар ўхшатиш воситасида ифодаланиб келинаётгани маълум бўлди.

Ўхшатиш дейилганда «нарса ёки ходисани маълум умумийликка эга бўлган бошқа нарса ёки ходиса билан таққослаш орқали ифодалаш, тасвирлаш» [4., 198]. тушунилади. Ўхшатиш аслида бадиий адабиётда, оғзаки нутқда кенг ишлатиладиган лисоний воситадир. Шу билан бирга, ўхшатиш лексемалар, терминлар, терминлар хосил қилишнинг мухим усулларидан бири хисобланади. Буни тадқиқот объектимиз материаллари хам тасдиқлай олади.

Тўпланган материаллар тахлилидан амалий санъат сохаларида ишлатилаётган луғавий бирликларнинг кўп қисми ўхшатиш йўли билан хосил қилинганлиги маълум бўлди. Ўхшатиш асосини табиат ва борлиқдаги хилма-хил нарса-предметларнинг номлари ташкил этар экан.

Хулоса қилиб айтганда, касб-хунармандлик терминлари лексикамизнинг каттагина қисмини ташкил этади. Касб-хунармандликка оид тушунчаларни лексемаларнинг маъноларини ўзгартириш, яъни ўзгартириш йўли билан ифодаланишини, уларнинг маъновий хусусиятларини аниқлаш ва тахлил қилиш лингвокултурология фанининг долзарб масалаларидан бири хисобланади.

\section{Адабиётлар:}

1. Худойберганова Д. Матннинг антропоцентрик тадқиқи.-Тошкент: Фан, 2013.

2. Иброхимов С. Фарғона вилояти касб-хунарлари лексикаси. Тошкент: Фан, 1959.

3. Худоёрова О. Ўзбек каштачилик санъати. -Тошкент, 1989

4. Ўзбек тилининг изохли луғати. V жилд.- Тошкент: “Ўзбекистон миллий энциклопедияси” Давлат илмий нашриёти, 2007.

\section{К ПРОБЛЕМЕ ДИФФЕРЕНЦИАЦИИ ТЕКСТА И ДИСКУРСА}

Киселёв Дмитрий Анатольевич д.g6.н., доцент СамГИия Email:dkisselev@inbox.ru

Annotation: Within the framework of Text Linguistics, the question of the relationship between the concepts of text and discourse - the key terms for this area of linguistics - is still a subject of discussion. In this article, we intend to present and analyze existing points of view on this issue in order to present and justify our own vision of the issue.

В рамках лингвистики текста вопрос о соотношении понятий текста и дискурса ключевых терминов для данного направления языкознания - до сих пор остается предметом дискуссии. Далее мы намерены представить и проанализировать
Key Words: Text

Linguistics, Text, Discourse, Opposition, Dichotomy. 
существующие точки зрения на данную

проблематику с тем, чтобы изложить и обосновать собственное видение вопроса.

Некоторые исследователи [1; 2; 3] намеренно упрощают дискуссию, рассматривая эти понятия в оппозиции "письменный текст" - "устный дискурс". Мы полагаем, что такой подход неоправданно сужает объем данных терминов, т.к. сводит каждый из них лишь к форме языковой действительности, с опорой на единственный дифференцирующий признак - использование/неиспользование письма. Подобная трактовка присуща некоторым формальным подходам к исследованию языка и речи.

Как следствие данного подхода, сокращается и исследовательское пространство научной дисциплины, т.е. дискурс-анализ должен быть направлен на изучение только устной речи, а объектом лингвистики текста может быть лишь письменный текст. Однако подобный редукционизм зачастую оказывается неэффективным, хотя бы потому, что значительное число текстов существуют и функционируют как в устной, так и в письменной форме (доклад, речь для публичного выступления, художественный/поэтический текст для декламации и т.п.).

Термин дискурс, который понимается как речь, "погруженная в жизнь", в отличие от текста, обычно не применяется по отношению к древним текстам, связи которых с живой жизнью не восстанавливаются непосредственно [4]. Однако в последнее время сформировалась тенденция к использованию методологического аппарата анализа дискурса и употреблению самого термина дискурс применительнок языковому материалу различной культурно-исторической принадлежности, например библейским текстам, а также произведениям литературы, текстам массовой культуры, психоанализу $[5 ; 6]$.

Существует также понимание дискурса исключительно как интерактивной формы коммуникации, что противопоставляется тексту, который обычно создается одним автором. Здесь можно увидеть некоторый параллелизм с уже известной дихотомией диалог - монолог.Само по себе противопоставление друг другу монологической и диалогической формы речи в значительной степени условно: реплика в диалоге может превратиться в полноценный монолог (произведения в эпистолярном жанре, политические дискуссии, научные диспуты и т.п.), а монолог, как речевой акт, всегда имеет адресата, реального или гипотетического, например alterego говорящего и т.д. На диалогическом характере речи и текста вообще настаивают многие исследователи, в частности М. Бахтин [7].

Аргумент в пользу того, что анализ дискурса включает в себя изучение социокультурных аспектов речевого общения, не может быть основанием для редукции исследовательского пространства до пределов устного диалога - практически любой фрагмент речевого общения, включая самый обычный письменный текст, может быть предметом социокультурного анализа.

Во многих исследованиях, направленных на изучение функциональных аспектов текста, можно обнаружить тенденцию к дифференциации дискурса и текста на основе ряда признаков, которые можно было бы охарактеризовать как коррелятивные: актуальность - виртуальность, динамичность - статичность, функциональность структурность, процесс - продукт.В соответствии с подобным подходом, противопоставляются структурный текст-как-продукт и функциональный дискурс-какnроцесc [text-as-product, discourse-as-process-8, 24].

С другой стороны, термины "текст" и "дискурс" очень часто употребляются как абсолютные синонимы: там, где одни говорят о "дискурсе" и "анализе дискурса", или "дискурс-анализе", другие оперируют терминами "текст" и "анализ текста", или "текстуальный анализ" соответственно. По мнению многих лингвистов, эти понятия не следует считать тождественными. Так, Ж.-М. Адам отмечает, что хотя и лингвистика текста и анализ дискурса зарождаются в 50-х гг. XX в., их исторические и 
гносеологические основы разнятся [9, 13]. За последнее десятилетие XX в. в теоретическом и методологическом плане произошла существенная эволюция, выразившаяся в переходе от начального отрицания деконтекстуализации к последующему размежеванию "текста" и "дискурса".

Выбор термина "дискурс"в качестве родового понятия определяет общий характер научной парадигмы. Как следствие, анализ дискурса (дискурсанализ)воспринимается как более широкая теория и практика научного исследования; европейская школа лингвистики текста концентрируется на изученииписьменных текстов; американский же конверсационный анализ сфокусирован на исследовании повседневной устной речи $[10,90]$.

Включение лингвистики текста в общие рамки анализа дискурса ничуть не принижает значимости первой, целью которой является предоставление пользователю языка инструментов чтения и понимания текстов, как продуктов дискурсивной деятельности человека. Опираясь на лингвистические и нелингвистические дисциплины, связанные, так или иначе, с текстом, лингвистика текста позволяет проследить, как последовательность высказываний образует смысловое целое $[9,14]$.

Приводимая ниже схема представляет собой доработанное схематическое представление взаимоотношения анализа дискурса и лингвистики текста Ж.-М.Адама $[9,31]$, что позволяет не только определить место каждой дисциплины, но и уточнить цели каждой из них.

\section{А н а ли 3 ди ск у р с а}

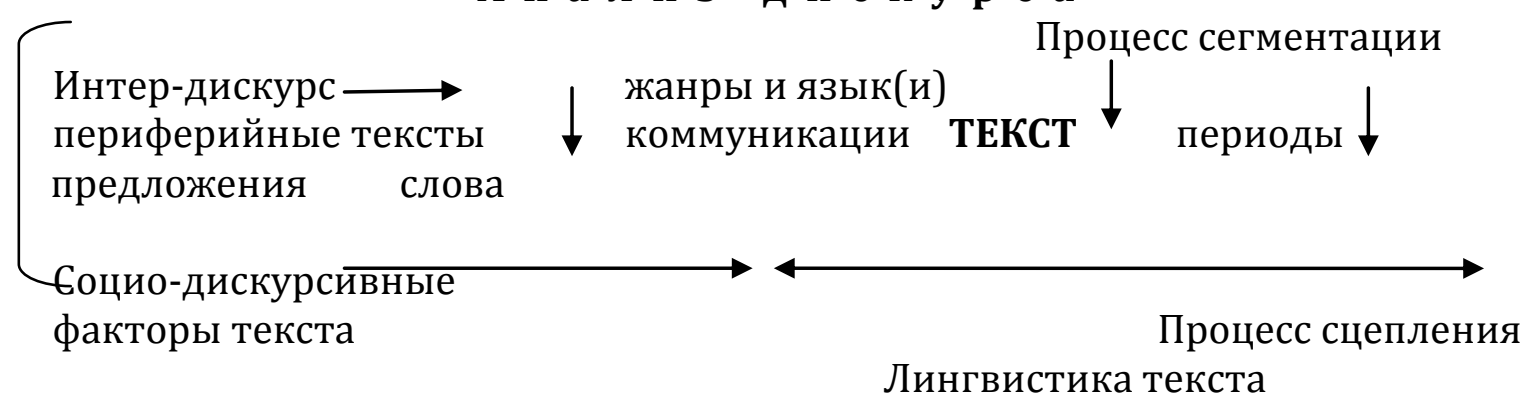

\section{Рис. 1. Схема соотношения анализа дискурса и лингвистики текста}

Данная схема (Рис. 1) позволяет наглядно отобразить: "по восходящей" (справа налево) этапы формирования текста - сцепление предложений с целью образования единого текста, который является объектом изучения лингвистики текста, а "по нисходящей" (слева направо) факторы (социальные, языковые, жанровые и т.д.), влияющие на формирование высказываний, что составляет объект изучения анализа дискурса. В результате этого взаимодействия, под влиянием потребностей выражения и речевого взаимодействия высказывания принимают разнообразные (до бесконечности) формы, которые регулируются языком и жанрами.

При этом, текст является объектом двух разнонаправленных процессов. С одной стороны, имеет место процесс синтеза текста - смысловое целое образуется в результате сцепления элементов по восходящей: слова объединяются в предложения (высказывания), которые образуют периоды текста, совокупность которых генерирует текст. С другой стороны, текст может быть подвергнут анализу - для осмысления текста необходима его сегментация: понимание текста складывается из понимания его периодов, интерпретация которых зависит от понимания предложений, состоящих из слов. Оба этих процесса - сцепления составляющих в целях генерации текста и сегментация текста в целях его осмысления - являются неотъемлемыми атрибутами всякого текста. Будучи разнонаправленными, они не противоречат друг другу, а наоборот, взаимно дополняют, потому что всякий текст создается для того, чтобы быть понятым и осмысленным. 


\section{Литературы:}

1. Бахтин М. М. Человек в мире слова. - М.: 1995.

2. Гальперин И.Р. Текст как объект лингвистического исследования. - М.: 1981. -140 с.

3. Макаров М. Л. Основы теории дискурса.- М.: ИТДГК "Гнозис", 2003. -280 с.

4. Миловидов В. А. От семиотики текста к семиотике дискурса. - Тверь, 2000.

5. Реферовская Е.А. Коммуникативная структура текста в лексико-грамматическом аспекте. Л.: Наука, 1989. - 167 с.

6. Adam J.-M. La linguistique textuelle. Armand Colin, 2015. 320 p.

7. Brown G., Yule G. Discourse Analysis. Cambridge University Press, 1983.

8. $\quad$ Coulthard M. (ed.) Advances in Written Text Analysis. - London, 1994.

9. Salkie R. Text and Discourse Analysis. - London; New York, 1995.

10. Лингвистический энциклопедический словарь (гл. ред. В.Н. Ярцева). Режим доступа http://www.lingvisticheskiy-slovar.ru/

\section{В.МАТЕЗИУСНИНГ ГАПНИ АКТУАЛ БЎЛАКЛАРГА АЖРАТИШ НАЗАРИЯСИ ВА ИЛОВА ХОДИСАСИ}

\section{Бегматов Мухтор Бегматович СамДЧТИ доценти Email:begmatov@samdchti.uz}

Annotation:This article provides statements on the theoretical and practical significance of the research of the famous Czech linguist $V$. Matesius on the theory of the separation of speech into relevant parts and the phenomenon of accession. Attempts have been made to explain the concepts of rema and topics, which are important parts of speech, in the framework of the connecting structure.
Key Words: actual members of the sentence, the phenomenon of accession, connecting structure, rema and theme, mono- and multifunctionality.

Гапнинг актуал бўлакларга ажратиш ходисаси тўғрисидаги назария чет эл ва рус тилшунослигида кенг кўламда қўлланилиб келмоқда. Ушбу назария асосан чех тилшунослик мактабининг асосчиларидан бири В.Матезиусга [Mathesius 1947] тааллуқлидир. Кейинчалик бу назариянинг тарафдорлари кўпайиб борди. Уларнинг орасида К.Г.Крушельницкая [Крушельницкая 1956], И.П.Распопов [Распопов 1961] ва В.Г.Адмониларнинг [Адмони1969] олиб борган ишлари диққатга сазовордир. Дастлабки вақтларда гапни актуал бўлакларга ажратишда интонацияга алохида ўрин берилган. Гапнинг актуал бўлакларга ажралиши унинг коммуникатив мақсадини ифодалайди ва у синтактик жараёнда тахлил қилинади. Хар қандай гапнинг фақатгина матн доирасида тахлил қилиниши мақсадга мувофиқдир. Шундагина у хақиқий синтактик ва интонацион маъно касб этади ва унинг актуал компонентларига ажралиши реал холатда бўлади. Маълумки, бир гапни бир неча актуал бўлакларга бўлиш мумкин. Гапни актуал ажратиш деганда гапни икки бўлакка тема ва ремага ажратиш тушунилади.

Тема ахборот предмети, яъни фикр харакатининг бошланиши бўлса, рема-бу унинг ривожланишидир. Бу холатни қуйидаги мисол орқали изохлаш мумкин; масалан, “ich" берилган дейлик, яъни бу тема функциясини бажариб келади, унинг ривожланиши учун рема керак, рема ана шу темани тўлдириш мақсадида юзага келади - у холда ich $\underline{\mathrm{kam}}$, демак, бу содда гап таркибида тема ва ремани тушунамиз. Албатта, бундай холни кенгайтирилган гаплар таркибида хам кузатиш мумкин, у холда қайси бир гап бўлаги биз учун мухим бўлса, унга мантиқий урғу бериб ажратиб кўрсатамиз.

Бироқ, бизнинг асосий мақсадимиз бу ерда гапнинг актуал бўлаклари бўлмиш рема ва тема тушунчаларини илова конструкция табиатига мослаштиришдан иборат, чунки рема ўз мохияти жихатидан темага нисбатанқушшимча ахборот беради, яъни уни конкретлаштиради, тўлдиради. Реманинг ана шундай хусусиятини эътиборга олган 
тилшунос олимлар, уни илова конструкциянинг рамкаси доирасида тушунтиришга харакат қилишган. Бу сохада М.Е.Шафиро олиб борган илмий-тадқиқот ишлари диққатга сазовордир. Чунки у биринчилардан бўлиб ремага хос бўлган хусусиятларни иловали элементлар ёрдамида тушунтириб берган, натижада гапнинг актуал бўлакларидан бўлмиш реманинг иловали элементларга муносбати [Шафиро 1965: 34] мавзусидаги илмий мақоласи юзага келди. Ремани иловали элемент функциясида қуйидагича тушунтириш мумкин:

Damals hatten wir noch nicht genügend Medikamente. Keine Betäubungsmittel [Thürk Harry 1968:225].

Рема хам ўзининг лингвистик мохияти жихатдан иловали элементнинг ўзгинасидир, чунки иловали элемент ўз таркибида реманинг хусусиятларини такрорлаб, олдиндан айтилган фикрга қўшимча маъно бериш ёрдамида юзага келади, яъни бу қўшимча маъно конкретлаштириш, тўлдириш, изохлаш, аниқлаш каби коммуникатив функцияларга эга. Бошқача қилиб айтганда, темада айтилган фикрни ривожлантиради, тўлдиради. Демак, рема энди оддий бир гап таркибидан чиқиб, илова конструкция ёки мураккаб синтактик бутунлик таркибида харакат қилади.

Ремани иловали элементга тенглаштириш ёки иловали элементларни рема функциясида талқин қилиш кўпгина олимларнинг диққат марказида бўлмоқда. Масалан, Е.А.Реферовская "рема бу айтилган фикрга қўшимча маъно англатувчи компонентдир, яъни иловали элементнинг ўзгинасидир” [Реферовская 1983: 24], дейди. B.A. Дмитренко рема тўғрисида Е.А. Реферовскаянинг фикрини давом эттириб, бу тўғрисида шундай ёзган: “гапнинг актуал бўлакларга бўлиниши, уларнинг грамматик бўлинишига нисбатан ижобий характерга эга, бу ерда рема якунловчи, тугалловчи компонент сифатида юзага келади [Дмитренко 1986: 21]. Ремага нисбатан келтирилган фикр ва мулохазалар борган сари кенгайиб, аниқланиб, тўлдирилиб борилади, яъни рема бу иловали элемент, иловали элемент бу реманинг ўзгинасидир, деган тушунча майдонга келади. Фикримизнинг исботи учун Н.А. Фролованинг қуйидаги хулосаларини келтиришни ўринли деб хисоблаймиз: “Иловали конструкция таркибида -why, sches the most important thing there is. To me. And to you Thomas - яъни -to me and to you Thomasкаби иловали элементларнинг келиши, уларнинг фақатгина рема функциясида келишини эмас, балки полирема функциясида хам кела олишини исботлайди" [Фролова 1967: 120].

Демак, Н.А. Фролова томонидан айтилган бу мулохаза юқорида айтилган баъзи бир фикрларимизни исботламоқда, чунки бу ерда келтирилган полирема иловали элементнинг моно- ва полифункционаллигини эслатади. Бу иловали элемент фақат рема функциясида келмасдан, балки ана шу рема функциясида келувчи иловали элемент учун тема хам бўлиши мумкин, деган хулосани келтириб чиқаради.

Иловали элементларнинг гапнинг актуал бўлиниши компонентларига нисбатан бўлган синтактик муносабатларини изохлаб беришга жуда кўплаб илмий мақолалар бағишланган, бироқ уларнинг барчасини бу ерда такрорлаб бўлмайди. Намуна тариқасида Е.А. Реферовскаянинг яна бир мулохазасини келтиришни ўринли деб биламиз, чунки бу мулохаза илова конструкция атрофида мавжуд бўлган баъзи бир саволларга ижобий жавоб тариқасида хизмат қилиши хам мумкин. Жумладан, Е.А. Реферовская иловали элементга хос бўлган айрим хусусиятлар тўғрисида шундай ёзади: “Иловали элементлар хеч вақт автономия холатида булмайди, яъни ўз-ўзини мустақил идора қила олиш хуқуқига эга эмас, чунки у рема характерига эга, у фақат автономия шаклида ўзи бевоста боғлиқ бўлган компонент ёнида кела олиши мумкин холос" [Реферовская 1983: 27]. Хақиқатдан хам, Е.А. Реферовскаянинг ушбу хулосаси жуда кўплаб саволларга жавоб бўлиши мумкин. Чунки, иловали элементнинг ўзи якка холда кела олмайди, фақатгина матн таркибида, яъни мураккаб синтактик бутунлик таркибида иловали элемент хусусиятига эга бўла олиши мумкин. Чунки, унинг мохияти 
“илова"дир, айтилган фикрга қўшимча маъно берувчидир. Унинг иловали элемент эканлигини фақатгина у ёки бу илова конструкция таркибидагина сезиш, кўриш, тахлил қилиш мумкин.

Иловали элементга хос бўлган бундай ва бошқа хусусиятлар тўғрисида, яъни уларнинг кўп қиррали, кўп томонли функциялари тўғрисида аввалроқ гапириб ўтдик. Бироқ, иловали элементларга хос"бўлган хусусиятларни қанчалик тахлил қилмайлик, қанчалик изохламайликуларнинг янги-янги томонлари очилаверади ва изланиш объектигаайланаверади.

\section{Адабиётлар:}

1. Дмитренко B.A. Сопоставительный анализ сложносочиненных предложений, присоединительных конструкций и их роль в организации текста. Лингвистические и дидактические исследования германских и романских языков. Харьков: Изд-во Высшая школа, 1986. -с. 21-24.

2. Реферовская Е.А. Лингвистические исследования структуры текста. Л., 1983. -215 с.

3. Фролова Н.А. О соотношении парцеллированных конструкций и непарцеллированных предложений на синтаксическом и коммуникативном уровне. Сб. Структура и семантика единиц номинации. Л.1967. -с. 114-122.

4. Шафиро М.Е. К вопросу о присоединении. Вопросы синтаксиса и стилистики рус. литературного языка. Куйбышев, 1963. с. 59-77.

5. Mathesius V. Otak zvanem aktualnim celenen vetnem. Cestina aobecny jazykozut. Soubor Stati, Praha, 1947. $234 \mathrm{~s}$.

6.Thürk Harry. Der Tod und der Regen. Verlag Das neue Berlin, 1968, 335 S.

\section{ТРАКТОВКА ФИЛОСОФСКИХ ПРОБЛЕМ}

\section{тоирова Дилфуза Файзуллаевна д.ф.н (PhD) доцент, СФ ТУИТ}

Annotation: The article deals with Stendhal's philosophy, aesthetics and psychology. However, Stendhal's main and most striking characteristic was a thirst for consistency, not a love of paradoxes and mental improvisation. $=$
Key Words: genre, literature, art, philosophy, aesthetics, history, events, world, essays, hero, etc.

Работа Стендаля над философскими проблемами, осаждавшимися в начале века, в основном была закончена ко времени его вторичного поступления в армию. Историей как наукой философской он заинтересовался несколько позже. Она никогда не покидала его мысли и воображения и всегда участвовала в его эстетическом и художественном труде.

История как литературный жанр была близка художественной литературе, хотя и противопоставлялась художественному вымыслу - жанру более свободному, а потому более поучительному и оптимистическому. Но самое понятие истории, как и всякое понятие, было историческим. Оно эволюционировало вместе с политическим движением времени, и Стендаль, всегда, даже в юношеские годы, державший руку на пульсе эпохи, менял своё понимание истории, как то подсказывали события.

Сначала Стендаль подошёл к история как писатель, или, точнее, комедиограф. История была для него тем же, чем она была для просветителей: повествовательным жанром морального и психологического плана, полезным для того, чтобы познать страсти и характеры, тщеславие великих мира сего, безумие людей, преданных своим интересам. «Из всего, что я прочёл и что видел до сегодняшнего дня, я запомнил только то, что мне казалось полезным для таланта, который я хочу развить в себе, - великого 
живописца характеров. Какую пользу может извлечь из истории тот, кто хочет стать величайшим поэтом?».1

В исторических сочинениях его особенно интересуют анекдоты, повествующие о мелких событиях придворной жизни, скандальная хроника двора, романтические, сугубо ничтожные причины больших политических событий. Это был «особый историографический жанр, называемый анекдотическим, который имеет своей задачей заполнить пробелы большой истории», как характеризовал его в 1781 г. Шамфор. ${ }^{2}$ Так понимал этот жанр и Стендаль. Он читает «Мемуары Фелиции Л.» мадам де Жанлис заинтересовавшие его как сборник анекдотов о XVIII в., но поучения, которыми автор сопроводил свои воспоминания, показались ему скучными и вызвали резкие возражения. ${ }^{3}$ Он с удовольствием прочёл воспоминания маркизы де Келюс, непринуждённо изображавшей двор Людовика XIV.4 Затем пришла очередь «Мемуаров Шевалье де Граммона», которые радуют Стендаля своим остроумием и весёлыми приключениями, и ему кажется, что это и есть стиль придворной жизни Людовика XIV. ${ }^{5}$

В записях Стендаля сохранились отклики на эти сочинения. Ещё Альфьери убедил его в том, что Монтескье вступил в компромисс с монархическим принципом. Глава IX «Lettresdecoт праваасhet» называется: «Опровержение правила Монтескье, считающего, что в некоторых случаях следует подавлять свободу». Стендаль видит в этом правиле компромисс: Монтескье часто «отказывался от права ради факта», и потому Мирабо справедливо упрекал Монтескье в том, что, вступая в компромисс со священниками и королями, он жертвует естественным правом ради права исторического. 6 Сочинения Мирабо привлекают Стендаля в этот «якобинский» его период страстной критикой монархии, в частности двора и политики Людовика XIV, описанием двора Фридриха II, психологическими портретами и анекдотами. Из «Истории Берлинского двора» он делает выписки и радуется разоблачению этих придворных «тайн» ${ }^{7}$. Стендаля могла поразить мысль Мирабо о том, что история не нужна, потому что она прославляет царей героев и учит лицемерию. Это был выпад против «королевской» историографии, вызывавшей негодование Альфьери и многих других публицистов и историков.

В том же году Стендаль с увлечением читает «Мемуары» аббата Шуази, «Мемуары» герцога Шуазёля, посвящённые тому же периоду, исторические сочинения Дюкло и Мармонтеля, «Анекдоты о русской революции 1762 года» Рюльера и в следующем году - «Мемуары» Безанваля. Особенно интересует его Сен-Симон, «французский Тацит». 9 Это было все то же беспощадное, местами остроумное разоблачение старого режима в лице монарха и его придворных.

Философию Стендаля, его эстетику, психологию, политические и любые другие взгляды современники, да и более поздние исследователи понимали как нечто ни чем не сообразное, как жонглирование мыслью, вызванное желанием произвести впечатление, своего рода умственное кокетство. Однако основным и особенно ярким свойством Стендаля была жажда последовательности, не любовь к парадоксам и к умственной импровизации. Замечательная осведомлённость в вопросах, которые он обсуждал, внимание к традициям, боязнь необоснованного новаторства для него так же характерны, как самостоятельность суждений, независимость ума и оригинальность взглядов. «Ум XVIII в., заблудившийся в героической эпохе Наполеона», - определил его 
когда-то Казимир Страенский. ${ }^{1}$ Правильнее было бы сказать, что он настойчиво и уверенно пролагал путь новому веку. Он решал те же проблемы, над которыми бились все его современники, в контакте или в противоречии с ними, как каждый скольконибудь оригинальный мыслитель.

\section{Литературы:}

1. V.del Litto. La vie intellectuelle de Stendhal. Genèse et evolution de ses idées (1802-1821). Paris, 1959 , p. 188, n.263.

2. Choix de discours de reception à l’ Académie Française, t. II. Paris, 1808, p.219.

3. V. del Litto. La vie intellectuelle, p.191.

4. V. del Litto. La vie intellectuelle, p.196.

5. Esprit de Mirabeau, t. II. Paris, 1804, p. 392-393.

6. ВыпискиСтендаляизкнигиМирабо «Histoire secrete de la cour de Berlin ou correspondence d'un voyageur français depuis le mois de juillet 1786 jusqu'au janvier 1787» (2 vls. Paris, 1789). См.: Pensées, t. II, p. 330-337.

\section{ФОНЕТИЧЕСКИЕ И СЕМАНТИЧЕСКИЕ ОСОБЕННОСТИ УЗБЕКСКИХ И РУССКИХ АНТРОПОНИМОВ}

\section{Чупонов Отаназар Отаджанович д.g.н., доцент, Ургенчский государственный университет Саиджанова Светлана Арслановна Магистрант, Ургенчский государственный университет Email:effektra@mail.ru}

Annotation: The article is dedicated to the studying the phonetic and semantic peculiarities of name-words of children in the Uzbek and Russian families. The author has analyzed Uzbek and Russian anthroponyms and discovered their separate features. Then the proper nouns expressing person in Uzbek and Russian languages have been compared and there have been narrated conclusions on the same different sides between them.
Key Words: the phonetic and semantic peculiarities, anthroponyms, proper name, anthropoformants, name-words, consonance.

Определяя категорию антропонимов, А.В.Суперанская называет три отличительных признака, позволяющих разграничить собственные и нарицательные имена: “Основные отличительные признаки собственного имени заключаются в том, что: 1) оно даётся индивидуальному объекту, а не классу объектов, имеющих черту, характерную для всех индивидов, входящих в этот класс; 2) именуемый с помощью имени собственного-объект всегда четко определён, отграничен; 3) имя не связано непосредственно с понятием и не имеет на уровне языка четкой и однозначной коннотации" [1, 324] .

Отмечая сходства узбекских и русских антропонимов, нельзя не коснуться ещё одной особенности личных имён. Нам известно, что у многих народов существуют разные способы имянаречения. Один из них - это выбор имени детям одной семьи или даже целого рода по фонетической и семантической созвучности. В процессе нашего исследования выяснилось, что узбекским и русским семьям также присуща эта особенность: имена выбираются нарекающими по фонетическому или семантическому созвучию. В связи с чем мы делим узбекские и русские личные имена на две соответствующие группы:

I. Фонетическое созвучие собственных имен.Эта группа делится по следующим признакам: 1) по созвучию в конце личного имени, например, имя матери - Махбуба, а дочерей: Адиба, Матлюба, Сохиба. В данной серии имя матери совпадает с именами дочерей по последнему слогу -ба. Имя отца - Музаффар схоже по концу личного имени ap с именами сыновей: Искандар, Самандар. Такие серии личных имён в узбекских 
семьях могут охватить несколько поколений одного рода и семьи, когда дедушка - Али, отец - Вали, внуки - Наби, Гани и т.д.

К подобным сериям относится способ наречения с компонентом сложных имен улло, например, отец - Хайрулло, сыновья: Сайфулло, Асадулло и с помощью антропоформантов: -хон, -ходжа и др., например, имена сыновей в семье: Олимхон, Юсуфхон, Кодирхон; дедушка - Тошходжа, отец - Илёсходжа, внук - Махмудходжа.

Серии женских имён также образуются с помощью антропоформантов, присущих узбекским женским именам, присоединяющимся к концу имени -хон, -нисо, -бегим, -бону, -ой и т. п., например, мать - Саодатхон, дочери: Захрохон, Ойшахон и т.д. Имена дочерей в семье: Бахринисо, Зебинисо, Мехринисо; бабушка - Робиябегим, мать - Тошбегим, внучки - Нодирабегим, Шахлобегим; мать - Салимабону, дочери - Шарифабону, Саломатбону, Мадинабону и т.д.

В русской антропонимике также наблюдаются такое созвучие личных имён, например, отец - Юрий, сын - Георгий; мать - Галина, дочери - Ирина, Нина; отец - Павел, сын - Михаил; бабушка - Ирина, дочь - Светлана, внучка - Оксана; отец - Вячеслав, сыновья Владислав, Станислав и т.д.; 2) по начальной части личных имён: а) начальный звук личного имени, например, серии имён: дедушка - Саид, отец - Содик (Садык), внуки: Салим, Сардор. Или же мать - Латофат, дочери - Лутфинисо, Лутфия, Лобар; б) созвучие имяобразующих компонентов: дедушка - Абдулла, отец-Абдувосид, внуки: Абдусамад,Абдумумин, имена сыновей в узбекской семье: Шерали, Шермухаммад, Шержон или имя отца: Мухиддин, дочерей - Муслима,Мадина, имя сына - Махмуд и т.д.; в) антропоформанты в начале женского имени: Би-, Гул-, Биби- и т.д. Например, в узбекских семьях встречаются имена: мать - Гульсара, дочери - Гулнора, Гуландом, Гулчехра; бабушка - Бибижахон, мать Бибипошша, Бибинисо и т.п.

В русских семьях по сравнению с узбекскими редко придерживаются таких способов наречения, но, тем не менее, встречаются семьи, в которых дети названы созвучными именами: сын - Олег, дочь - Ольга; отец - Андрей, сын - Александр, дочь Алёна.

3) по созвучию личных имён по началу и концу: например, отец - Абуали,сыновья: Абдували, Абдугази, Абдугани; отец - Мухсин, сыновья -Мадамин, Мадусмон, Мумин; мать - Нодира, дочери Нигора, Нозима и т.д.

В русских семьях к таким сериям имён относятся имена: отец - Владимир, сын Виктор, отец - Андрей, сын - Алексей, мать - Алена, дочь - Анна, отец - Александр, дочь Александра. В русских семьях такие фонетические явления наблюдаются очень редко,что говорит о характерности данного способа наречения восточным странам.

Таким образом, можно считать, что данный фонетический способ входит в число традиций имянаречения семей восточных стран, в том числе узбекской. В русских семьях в основном, как уже было отмечено выше, придерживаются другого способа наречения: наречение детей именами родителей, например - Иван Иванович Иванов, Павел Павлович, и мать и дочь - Светланы и т.д. Из чего следует, что такой способ наречения является характерным для русской антропонимики.

II. Семантическое созвучие собственных имен. Кроме фонетического созвучия в узбекской и русской антропонимике ещё встречаются серии личных имён, созвучных по семантике:

имена членов семьи и соратников пророка Мухаммада, например, имена близнецов в узбекских семьях: мальчик и мальчик - Хасан и Хусейн (от имён внуковблизнецов пророка Мухаммада); мальчик и девочка - Хасан, 3(а)ухро (от имён старшего внука и дочери пророка Мухаммада); отец - Мухаммад, сыновья Умар, Усмон, Абубакр (от имён халифов); мать - Хадича, дочери - Ойша, Фотима, 3(а)ухро (от имён жён и дочерей пророка Мухаммада) и т.д.; 
имена от названий растений или фитонимов: мать - Райхон, дочь - Савсан; имена сестёр в одной семье: Бунафша, Райхон, Лола, Наргиз и т.д.;

имена персонажей «Шахнаме»: отец - Рустам, сын - Сухраб, дочь - Фарангис; имена брата и сестры - Бежан и Манижа; имя матери -Тахмина, дочери - Фарангис, сына - Рустам;

4) исторические имена: братья - Саман (от названия династии древнеиранских царей), Бахром - от имени древнеиранского царя и т.д.

В русских семьях также придерживаются таких обычаев имянаречения и при наречении детей используются следующие серии: 1) от имён православных святых: отец - Василий, сын - Григорий; 2) от имён героев произведения «Слово о полку Игореве»: братья Игорь, Олег и сестра Ольга и т.д.

Таким образом, в своем исследовании мы постарались осветить наиболее характерные особенности наречения детей в узбекских и русских семьях. Также нами выполнен сравнительно - сопоставительный анализ моделей узбекских и русских антропонимов, который показал соответствие в их фонетической, морфологической и словообразовательной структуре, не считая некоторых особенностей, о которых мы упомянули выше.

\section{Литературы:}

1. Суперанская А.В. Имя нарицательное и собственное.- М.: Наука, 1978.

2. https://ismlar.com/uz / http://rus-yaz.niv.ru/

\section{МАТНЛАРНИ ҚАЙТА ИШЛАШ ЖАРАЁНИДА ПРАГМАТИК ИМПЛИЦИТЛИКНИНГ ИФОДАЛАНИШИ ХУСУСИЛА}

Шерматов Акрам

СамдЧТИ доценти

Email:shermatov@samdchti.uz

Annotation: The article is about the impact of implicit positions to the content of the text processing characteristics. Besides this, the relationship between the speaker and the addressee of the deictic center in the content of the text, a system of references that can characterize the role of implicit in referring to referential situations in ensuring implicitness in texts and anaphoric and cataphoric features of text have been analyzed.
Key Words: deixis, deictic units, text, speaker, addressee, deictic centre, pragmatic, implicit, context, implicit structure, reference.

Дейксис ходисаси тил тизимидаги қатор ходисаларни фақатгина уларнинг юзмаюз мулоқот шароитида шаклланишини инобатга олгандагина яққол кўзга ташланади. Дейксис ходисаси хар қандай тил тизимида ўз ўрнига эгадир хамда матн таркибининг шаклланишида учрайди. Инглиз тилида тил тизими ва контекст ўртасидаги боғлиқликни кўрсатувчи ходиса-дейксис хисобланади. Дейксис ходисасининг яна бир ахамиятга молик томони, бу тилнинг нутқ билан биргаликда боғланишидир. Бошқача қилиб айтганда, дейксис ходисаси тил тизими ва унинг нутқий фаоллашуви ўртасидаги “воситачилик", "хакамлик” ролининг бажарувчиси бўлиб хизмат қилади. Дейктик бирликларни ўрганиш тилшуносликда матннинг прагматик маъносини изохлаш имкониятини беради. Шуни қайд этиш лозимки, дейктик бирликлар хар қандай матн тежамкорлиги хамда мазмундорлигини ошириши билан тилшуносларни қизиқтириб келмоқда.

Дейксиснинг қўлланиши ва матнда бажараётган функцияси хар бир тилнинг ички грамматик-структур тузилишига асосланган ва қонун қоидалардан четга чиқмаган холда матнда қўлланилади. Дейксис ёки унга боғланган сўзларнинг ўрнини алмаштириш гапда нотўғри грамматик тузилмани хосил қилиши, ёхуд грамматик структура ўзгармаганда хам англашилаётган мазмунни ўзгариб кетишига сабаб бўлиши мумкин. Тил бирликларининг ўзаро бирикиши қонуниятларини кузатиш, бир томондан, 
уларнинг маъно хусусиятларини ойдинлаштириш имконини берса, иккинчи томондан, бу бирликларнинг маъно кўламини аниқлашга асос бўлади $[1,18]$.

Матн ўз ўрнида ташкиллаштирилган тизим сифатида қаралади. Матн адресант томонидан эксплицит жавоб талаб қилмайдиган битта гап (масалан, эълонлар тахтасидаги маълумот ва х.к.з) дан хам таркиб топиши мумкин. Шу ўринда икки яъни диалогик ва монологик турдаги матнларни кўриб чиқсак. Диалогик турдаги матнда иккита роль бажарадиган иштирокчилар мавжуд: адресант (гапирувчи) ва адресат (тингловчи). Ушбу жараёндан (агар улар мавжуд бўлса) ташқаридаги шахслар, тингловчилар хисобланади. Бу турдаги матнларда адресант дейктик марказ ролини бажаради. Бошқача айтганда, адресантнинг вазифаси дискурсни ташкил этиш. Бундай холатда гапирувчи бирон бир мавзу хақида сўз бошласа, адресат ўша холатга нисбатан ўз муносабатини билдиради. Жараёнда нафақат адресант балки адресат хам адресант ролига ўтиши мумкин. Дейктик марказ алмашган пайтда унга қўшилиб объект ва жараёнлар хам дейктик кўрсатиш вазифаларини ўзгартириб туриши табиий. Монологик турдаги матнларда дискурс ташкиллаштирувчининг роли ёзувчи томонидан белгиланади. Бу ўринда жараён иштирокчилари вазиятга қараб ўз ўрнида бўлиши мумкин. Мазкур турдаги матнларда гапирувчи жараённинг олдинги ва кейинги холатларига ишора қилиш мақсадида дейктиклардан оқилона фойдаланишга харакат қилади.

Айнан компьютер лингвистикаси нуқтаи назаридан олганда, матнларни қайта ишлаш жараёнида объектларнинг имплицит холатларда вазиятда воқеланишини кўриб чиқсак. Адресант ва адресатга қўлланилган дейктик имплицит роллар ва референция, умуман олганда, аниқ имплицит ролнинг умумий турига тааллуқлидир. Гарчи кўпгина тилларда морфологик хусусиятлар ёки специфик қурилмалар билан кодлаштирилган бўлса хам (мисол қилиб инглиз тилидаги буйруқ гапларни олиш мумкин), шундай тиллар мавжудки, контекстдаги референциал тузилмалар гапирувчи ёки адресатга тўғридан-тўғри жараён орқали шаъма қилиш имконини бера олади.

Put a pen on the table (Put=imperative).

I put a pen on the table. (Put=the past tense of the verb "to put", irregular verb)

Go out! (arg0=you)

Any recommendations? $(\arg 0=$ you, $\arg 2=m e)$

Матнларда прагматик жихатларни яъни имплицит холатларни китобхон эътиборига бевосита етказилишида хеч қандай чекловлар мавжуд эмас хамда улар хатто лингвистик мазмун-мохият жихатдан анафорик холда бўлмаслиги хам мумкин. Бундай холатларда имплицит тузилмалардаги маъно контекстнинг энг сўнггида тилга олинмаган конкрет хаволаларни хам назарда тутиш имконини бера олади. Дейлик, бирор киши хона ичкарисига кириб, “Биз ниятимизга эришдик” ёки “Китобларни токчадан олинглар" каби мисолларда адресант ва адресат ўртасидаги умумий хусусиятлар билан бирга имплицит қурилмаларнинг кимга тегишлилик жихатидан прагматик асосларни хам ўз ичига қамраб олганини кузатишимиз мумкин. “Биз ниятимизга эришдик” ёки “Китобларни токчадан олинглар” каби мисолларда адресант адресатга нисбатан айтган харакатида имплицит жихатдан “қанақа ниятга эришилди” ёки “қанақа китобларни токчадан олиш” деган мазмундаги дейктик холатлар матн ички тузилмасини яъни контекстга алоқадор бўлган сухбат иштирокчисига маълум бўлиши табиий $[2,95 ; 6,58 ; 3,14 ; 4,137]$. Гапирувчи матнда мавжуд бирор объектни яъни у бирор аниқ фреймга тегишли бўлса имплицит холатда қолдириш мумкин.

She perf signed

She signed $\emptyset$ the contract/deal

Theyperfbeat

They beat (them) 
Шунга ўхшаш имплицит шаклидаги мисоллар “кўп томонлама эътибор тортадиган” озгина бўлса хам мазмун мохиятни мужассамлаштирган холда имплицит интерпретациясини ўзида акс эттира олади. Имплицит ролнинг компьютер моделлари учун умумий масала борасида натижадор отлар ёки сифатлар билан боғлиқ алоқадорлиги хам ўз навбатида матн мазмундорлигини янада оширишга хизмат қилади $[5,23]$. Матнни қайта ишлаш жараёнида хар бир кичик деталь хам ўз маъно таъсирига эга.

Демак, матнларда имплицитликни таъминлаш борасида референциал вазиятларга ишора қилинишида имплицит ролни тавсифлаш мумкин бўлган хаволалар тизимидан унумли фойдаланиш ўринли хисобланади. Бу ўринда матнларда дейктик сўзларнинг анафорик ва катафорик холатларда имплицитликни хисобга олган холда жараёнда иштироки адресант ва адресатга бевосита мавжуд объектлар ёрдамида ишора қилинишига туртки беради. Чунки матнни прагматик жихатдан, ундаги дейктик бирликларнинг имплицит холатларда турлича вазиятлардаги иштироки хам диалогик хам монологик турдаги матнлараро воқеланишида адресантнинг адресатга бўлган мулоқотида ёки адресантнинг ўзи иштирокида бўлишидан қатъий назар дейктик марказдан узоқлашмаган холда амалга оширилади.

\section{Адабиётлар:}

1.Сафаров.Ш. Семантика. -Т.: Ўзбекистон миллий энциклопедияси давлат илмий нашриёти, 2013. -344 б.

2.Fillmore Ch. Pragmatically Controlled Zero Anaphora // In Proceedings of the12th Annual Meeting of the Berkeley Linguistics Society, Berkeley, California, 1986. -P. 95-107.

3.Glass L. 2014. What Does It Mean for an Implicit Object to be Recoverable?// University ofPennsylvania Working Papers in Linguistics, 2014. -P. 14-20.

4.Lambrecht, K., Lemoine L. 2005. Definite null objects in (spoken) French. In GrammaticalConstructions: Back to the Roots. John Benjamin's Publishing Company, 2005. -P.136-148.

5.0'Gorman J Timothy. Bringing Together Computational and Linguistic Models oflmplicit Role Interpretation.ThesisUniversity of Illinois Champaign-Urbana, 2019. -216 p.

6.RuppenhoferJ, Michaelis L. Frames and the interpretation of omitted arguments in English //Linguistic Perspectives on Structure and Context: Studies in Honor of KnudLambrecht,2014.-P.57-86.

\section{ФРАЗЕОЛОГИК БИРИКМАЛАР ТАРЖИМАСИ МУАММОЛАРИГА ДОИР}

\section{Нишонов Патхиддин ЎзДЖТу доценти}

Annotation: The present article analyses the problems of Key Words: Phraseological translation of the phraseological units from one language into units, translation, expression, another. The author highlights several options of translation of the equivalence, translation version. phraseological units.

Фразеологик бирликлар хар қандай тилнинг кўрки ва безаги хисобланади. Фразеология тилшуносликнинг алохида бир бўлими бўлиб, унда кўчма маънога асосланган турғун бирикмалар, иборалар ўрганилади. Тилшунослик бўлими сифатидаги фразеологиянинг асосий диққат эътибори фразеологизмлар табиатини ва уларнинг категориал белгиларини ўрганишга, шунингдек, фразеологизмларнинг нутқда қўлланиш қонуниятларини аниқлашга қаратилади. Биз ушбу мақоламизда фразеологик бирликларни таржимада акс эттириш муаммолари тўғрисида фикр юритишга харакат қиламиз.

Фразеологик бирликлар нафақат тилнинг ўзига хослиги, унинг турли маъно қирраларини акс эттирувчи восита, балки халқнинг тарихий ривожланиши, маданий 
юксалишини хам кўрсатиб берувчи кўзгу хамдир [2, 15]. Фразеологик бирликларни таржима қилар экан, таржимон иборанинг нафақат маъносини англаб етиши ва уни ўз тили воситалари орқали ифодалаши, балки энг мухими, унинг миллий ва маданий ўзига хослигини сақлаб қолмоғи лозим.

Таржима нуқтаи назаридан фразеологик бирликлар одатда икки гурухга бўлинади: таржима тилида муқобилга эга бўлган фразеологик бирликлар, муқобилга эга бўлмаган фразеологик бирликлар. Тилшунос олимлар лексик, грамматик, семантик ва стилистик даражадаги ўхшаш ва фарқли жихатларга кўра муқобилликнинг бир неча турларини ажратиб кўрсатадилар. Тўлиқ муқобиллик [3], селектив муқобиллик, қисман муқобиллик, калька. Энди муқобилликнинг мазкур турларини алохида кўриб чиқамиз.

Тўлиқ муқобилликда таржима тилида асл матндаги фразеологик бирликка маъно жихатдан мутлақ мос келувчи фразеологик бирлик мавжуд бўлади. Бу икки фразеологик бирлик маъноси жихатидан, лексик таркиби, грамматик структураси, стилистик қурилишига кўра ўзаро тенгдир [4, 89]. Масалан, tirer les marrons du feu - таскать каштаны из огня. Мазкур фразеологик бирикма француз ва рус тилларида бир хил маъно, яъни “бировнинг фойдасига қийин ишни бажариш" маъносини ифодалайди. Ўзбек тилида мазкур фразеологик бирикманинг маъносини “ўроқда йўк, машоқда йў, хирмонда хзозир" мақоли билан ифодалаш мумкин. Etre entre le marteau et l'enclume - быть между молотом и наковальней - être dans une position où le danger ou la difficulté menace de deux côtés. Бу фразеологик бирикма "хар икки томондан хавф ва қийинчилик билан ўралган бўлмоқ" маъносини англатади. Ўзбек тилида унга “икки ўт ўртасида қолмоқ" ибораси муқобил бўлади. Prendre le taureau par les cornes - взять быка зарога= commencer à agir de manière décisive dès le début. Мазкур иборанинг айнан таржимаси “хўкизни шохидан олмоқ" маъносини беради ва у кўчма маънода “қийин ишга бирдан ва дадил киришмоқ, бирор ишни қатъият билан бажармоқ” маъносида қўлланилади. Икки тил ўртасида мутлақ муқобилларнинг бўлиши таржимада асл матннинг тўлиқ маъносини беришга имкон яратади.

Бундай турдаги фразеологик бирикмаларни таржимаси мураккаб бўлмаса-да, бироқ улар тилда кўпчиликни ташкил этмайди. Шунинг учун икки ва ундан ортиқ тилда шакли ва мазмуни бир хил бўлган ибораларни халқаро иборалар деб аташ мумкин. Бундай иборалар тили ва маданияти бир-бирига яқин бўлган халқларда кўпроқ учрайди. Халқаро ибораларнинг этимологиясидан келиб чиқиб уларни икки гурухга бўлиш мумкин. 1) ривоят, мифологик афсона, лотин ёки грек тилларидан сақланиб қолган иборалар. Масалан, le пюиd gordien - гордиев узел = une tâche difficile à résoudre, une affaire confuse = чигал масала, ечими қийин бўлган иш; franchir le Rubicon - перейти Рубикон = faire un acte décisif, ayant une importance tournante dans la vie = қатъий харакат қилмоқ, кескин иш кўрмоқ. 2) турли тилларда мавжуд, бироқ келиб чиқиши бир-бирига боғлиқ бўлмаган фразеологик бирикмалар. Бундай иборалар бир қатор экстралингвистик сабабларга кўра турли тилларда юзага келган бўлади ва халқларнинг тасаввури бирбирига яқинлигини кўрсатади. Масалан, jour et nuit - день и ночь = туну-кун. Бирор харакат ёки воқеликнинг давомийлигини англатади; serrer la queue - nоджать хвост = avoir peur = думи қисилган. Қилган ишининг сири очилиб қолгач, унинг натижасидан қўрқиш холатини англатади.

Мутлақ муқобил иборалар борасида яна шуни айтиш керакки, икки тилда бир хил шаклда мавжуд бўлган иборалар баъзан мутлақо бошқа-бошқа маънони ифодалаши мумкин. Масалан, рус тилидаги держать нос по ветру ибораси фикридан қайтмоқ, шароитга мослашиш маъносини англатса, француз тилидаги porter le nez au vent ибораси тўйиб нафас олиш маъносини ифодалайди. Бошқа мисолга мурожаат қиламиз: свалиться с луны - tomber de la lune. Рус тилидаги ибора хамма биладиган, оддий нарсани хам тушунмаслик маъносини ифодаласа, француз тилидаги ибора эса хайратда қолмоқ (être très surpris, étonné) маъносини ифодалайди. Француз ва рус тилларида белая ночь - 
la nuit blanche иборалари мавжуд. Бироқ уларнинг шакли бир хил бўлгани билан маъноси турлича. Рус тилидаги иборада ёруғ тунлар, бахорда ва ёзда шимолда бўладиган қисқа ва ёруғ тунлар назарда тутилса, француз тилидаги иборадан уйкусиз ўтказилган тун маъноси келиб чиқади. Яна бир мисол, рус тилидаги гнуть спину ибораси бели букилгунча ишлаш, силласи куригунча ишлаш маъноларини англатган холда, унинг француз тилидаги шаклдоши courber l'échine эса таслим бўлмоқ, бўйин эгмоқ маъносини ифодалайди.

Селектив муқобиллик. Бундай муқобилликда таржима тилида асл матндаги фразеологик бирикмага мос келувчи бир неча вариант мавжуд бўлади. Таржимонда эса улар орасидан энг мақбул иборани танлаш имкони бўлади. Бундан ташқари, асл матнда бир ибора бир неча марта қўлланилган бўлса таржимада уни бир неча вариантда ифодалаш хам мумкин ва бу сўзсиз таржима матнини бойитишга хизмат қилади. Масалан, француз тилидагиil a la main sûr ибораси рус тилига у него твердая рука (il a une main ferme), ва у него рука не дрогнет (sa main ne tremblera pas) шаклида таржима қилиш мумкин. Бошқа мисол: porter de l'eau à la mer - дровавлесвозить (transporter le bois de chauffage dans la forêt) ва водувколодецлить (verser de l'eau dans le puits).

Қисман муқобиллик. Бундай муқобиллик мазмуннинг қисман акс эттирилишини англатмайди, балки икки тил ўртасида лексик ёки граматик шакл турлича бўлишини билдиради. Масалан, пальщем не шевельнуть (ne bouger plus d'un doigt) - ne bouger plus d'un pouce ; скрестить шпаги (pl) - croiser le fer (sing), проглотить язык - avaler sa langue (француз тилида эгалик олмоши иштирок этмоқда), не верить своим ушам - пе pas en croire ses oreilles (француз тилида en олмоши иштирок этмоқда).

Хулоса ўрнида айтиш керакки таржимон фразеологик бирикмаларни бир тилдан иккинчи тилга таржима қилишда уларни хар икки тилда чуқур билиши лозим. Фразеологик бирикмаларни таржима қилишнинг биз кўриб чиққан усуллари ичида мутлақ муқобиллик шакли энг ишончли усул бўлса-да, аммо улар тиллар ўртасида кам учрайди. Шу сабабли фразеологик бирикмаларни муваффақиятли таржима қилиш кўп жихатдан таржимоннинг махоратига боғлиқ бўлиб қолаверади.

\section{Адабиётлар:}

1.Барушкова С.Б., « Фразеосемантическое поле « Трудовая деятельность человека » как фразеологический класс фразеологической системы » (на материале французского языка) (монография). - Ярославль : Изд-во ЯГПУ, 2009, 160 с.

2.Белинский В.Г. Взгляд на русскую литературу / В.Г. Белинский. - М.: Современник, 1997. - 460 с. Гак В. Г. Теория и практика перевода. - М.: Интердиалект+, 1997 - 366 с.

3.Кунин А.В. О переводе английских фразеологизмов в англо-русском фразеологическом словаре - М.: Мост, 2001. - 320 с.Французско-русский фразеологический словарь (ФРФС) / под ред. Я. И. Рецкера.- М.: Гос. изд-во иностр. и национ. словарей, 1963.

\section{ШЕЪРИЙ ТАРЖИМА ВА УНДАГИ ЭСТЕТИК - МАЗМУНИЙ ХУСУСИЯТЛАР}

\section{Бўриева Наргиза Кўчқаровна Жиззах Давлат Педагогика Институти мустақил изланувчиси}

Annotation: This article discusses the existence of a poetic translation of Key Words: poetic original poetic texts to ensure a spiritual connection between the author and his associates. The translated poetic texts are described as a more complex communicative process, establishing a spiritual connection between the author and his (non-original) language and students brought up in a different culture.

translation, poetic version, actual and conceptual, originality, form.

Ўтган асрнинг иккинчи ярмидан бошлаб Ўзбекистонда, шеърий таржимада астасекин етакчига айланган ва энди у одатда энг табиий усул сифатида қабул қилинган 
усул вужудга келди. Унинг мохияти шундаки, шеърий версия аслиятнинг мазмуни ва шаклининг бадиий бирлигини яратиши керак, тафсилотларда қанчалик аниқ бўлишидан қатъий назар, уни ўлик фотокопия ёки жонсиз схема сифатида эмас, балки тирик ва яхлит шеърий организм сифатида қайта ишлаб чиқиш керак.

Бошқача қилиб айтганда, шеърий таржима асл нусханинг тирик эгизагига айланиши ва таржима қилинаётган тилда тўлақонли адабий жараёнда фаол иштирок этиши керак. Табиийки, ушбу мақсад учун - шеъриятда мавжуд бўлган асосий нарсани сақлаб қолиш, яъни мустақил шеърий қийматни сақлаш ва қайтадан тиклаш керак, бу ерда таржимонга майда-чуйда иккинчи даражали маълумотларга яқинликни қурбон қилиши талаб қилинади. Албатта, бунинг учун у, биринчидан, сезгир шоир, иккинчидан, тенг даражада сезгир филолог бўлиши керак.

Аммо ўзбек адабиётида бу усулнинг зафарли бўлиши автоматик равишда поэтик таржима жанрларида бир хилликни келтириб чиқармади. Коммуникатив-функционал пойдеворга асосланган таржима усулларининг типологик тизими аста-секин кристалланади. Ушбу тизимда таржиманинг тубдан бошқа турлари яшаш хуқуқини олади, аммо уларнинг хар бири ўзига хос функцияга эга.

Келинг, ушбу масалани батафсилроқ тушунишга харакат қилайлик. Шеърий таржима, хар қандай таржима сингари, биринчи навбатда, тиллараро ва маданиятлараро алоқанинг ходисасидир (акт)(1). Шу билан бирга, шеърий таржима фақат ва фақат тугалланган матндан фойдаланган холда шеърий маълумотларни узатишни амалга оширади, унинг хар бир таркибий қисми аниқ таркибни ва фақат ушбу яхлит матннинг бир қисми сифатида олади ва хеч қачон етарлича мустақил маънога эга эмас, яъни олдиндан маълумки синсемантикдир(юнонча "син" - бирга + "семантикос" маъно). (4) Мустақил маънога эга бўлмаган хизматни ўтайди. Синсемантик жумла (коммуникатив тўлиқлиги бўлмаган, бошқа жумлалар билан грамматик жихатдан боғлиқ бўлган жумла). Шу муносабат билан амалдаги умумий поэтик нутқ ва хусусан, шеърий поэтик таржима назарияси, агар керак бўлса, коммуникатив ва матнли бўлиши керак.

Келинг, баъзи дастлабки таърифларни келтирайлик.Мулоқот - бу муаллифдан ўқувчи / тингловчига "юборилган" маълум бир ахборот мажмуасини узатиш (қўзғатиш) жараёни.

Бадиий асар орқали амалга ошириладиган оғзаки алоқа бадиий-оғзаки коммуникация хисобланади. Ва нихоят, воситаси шеърий матнлар бўлган бадиийвербал коммуникация-бу поэтик коммуникациядир.

Матннинг таркибий қисмини тўлиқ равишда ушбу матннинг маълумотлари деб номлаймиз. Айнан шу тушунча, Шаннон ва Моле томонидан киритилган маълумотларнинг математик таърифига тўлиқ мос келмайди, бу фақат адабий алоқа назарияси учун қабул қилинади. (2)

Шеърий матннинг маълумотлари икки тубдан фарқ қиладиган кичик турларга бўлинади: мазмуний ва эстетик.

Ўз навбатида, мазмуний маълумот (қабул қилувчининг онгида маълум бир маълумот олиш холатини акс эттириш) икки хилга бўлинади: фактик ва концептуал (профессор И.Р. Галперин терминологиясида). (3)

Хақиқий маълумотлар бу хақиқий ёки хаёлий дунёда бўлган, бор, ёки келажакда содир бўладиган баъзи фактлар ва / ёки воқеалар хақидаги хабар. Бундай маълумотлар хар қандай, шу жумладан бадиий бўлмаган матнда хам мавжуд. Масалан: "Сиз қандай қилиб менинг хонамга тўсатдан кириб келганингизни эслайман ва мен ууйладим: бу аёл эмас, балки мўъжиза!".

Шундай қилиб, хар бир бадиий матнда юзаки фактик маълумотларга қўшимча равишда, чуқур концептуал семантик маълумотлар мавжуд бўлиб, улар бу ерда аниқ фактлар ва воқеалардан кўра мухимроқдир. У ўзида, охир оқибат, дунё тушунчасини акс 
эттиради, яъни бу дунё нима эканлиги ёки нима бўлиши керак ёки бўлмаслиги кераклиги хақида муаллифнинг хулосасини намоён этади. Ушбу маълумот хар доим ўз табиатига кўра яширин ва, ўз навбатида, ўз оғзаки ташувчиларига эга эмас - бу оғзаки шакл билан эмас, балки фактуал мазмуни билан эътироф этилади.

\section{Адабиётлар:}

1. Н. И. Балашов. Структурно-реляционная дифферренциация знака языкового и знак поэтического// -Изв. АН СССР. Отделение лит. и ин. яз., 1982. -№ 3.

2. Г. О. Винокур. 0 языке художественной литературы. // М.: Высшая школа, 1991. С. 65-69.

3. Гальперин И.Р. Текст как объект лингвистического исследования. // АН СССР, Ин-т языкознания. М., "Наука", 1981.

4. Й. Тынянов. Проблема стихотворного текста. // Вавилон: Вестник молодой литературы. Вып. 2 (18). - М.: АРГО-РИСК, 1993. ISBN 5-900506-06-1 с.86-90. /рубрика "Штудии"/

\section{НЕМИС ТИЛИДАН ЎЗБЕК ТИЛИГА ЎЗЛАШГАН ЛЕКСИК БИРЛИКЛАРНИНГ ДЕРИВАЦИОН ТАРКИБИ}

\section{Абдурахманов Сирожиддин Муминкулович Самарқанд Давлат Университети ўқитувчиси Email: s-abduraxmanov83@mail.ru}

Annotation: In this article is given an idea about the words which are the part of the German language dictionary and appeared into the Uzbek language. Accuredphonetical,orthographical and morphological changings were analysed during their adopting.The place of this lexical level in the Uzbek language is shown in a comparative way.
Key Words: structure dictionary, international words, etymology, lexeme, orthography, orthographical, orthoepic.

Хар қандай миллий тилнинг луғат таркиби, унинг жами сўз бойлиги мазкур миллатнинг бутун тарихий тараққиёти давомида шаклланган ходисадир.У доимо харакатда ва ўсишда бўлади.Тилнинг ривожланиш самараси эса, асосан икки омилга, унинг ички ва ташқи ўсиш манбаларидан қандай фойдалана билишига боғлиқ бўлади. Халқаро алоқаларнинг кенгая бориши, миллатллар муваффиқият ва ютуқларининг самимий умумлашуви, айниқса, фан, маданият, саноат, сиёсат сохаларидаги илғор тажриба алмашувлар, дунёнинг турли бурчакларидан келган хабар ва маълумотларни хар ким ўз она тилида қайта ишлаб чиқиши каби объектив ва зарурий омиллар тиллар ривожига, улар луғат таркибининг ташқи манбалар хисобига бойиб боришига баракали таъсир қилмокда.

Мазкур мақоламизда асосан ташқи манбалар таъсирида юз берган ўзбек тилидаги миқдор ва сифат ўзгаришларини ўрганишга харакат қилинди. Унда немис тилидан рус тили орқали ўзбек тилига кириб келган ўзлашмаларни дифферинциал тахлил қилиш кўзда тутилди. Зеро, ўзбек тилининг луғат таркиби, ундаги сўзларнинг этимологияси, имло талаффуз ва англатадиган маънолари билан қизиққан хар бир киши, миллий тилимиз ва сўзлашув нутқимизда немис тилига оид бўлган қатлам тил бирликларини пайқаши қийин эмас. Ўзбек халқи бу лексик бирликлардан ўзининг оғзаки ва ёзма нутқида фаол фойдаланиб келяпти.

Маълумки, бирор чет сўз иккинчи бир тилга қабул қилинадиган бўлса, қабул қилувчи тил уни, иложи борича, манба тилдаги имло ва талаффуз шаклини сақлаб қолиши керак. Ўзбек тилидаги немис тилидан қабул қилинган ўзлашмалар тахлилида шуни эсдан чиқармаслик керакки, улар ўзбек тилига келгунча, аввало рус тилида муайян имло ва талаффуз шаклларини олишган ва шу асосида ўзбек тилига ўтиб келишган.

Немисча ўзбекча 


$\begin{array}{lc}\text { Kran } & \text { кран } \\ \text { Ring } & \text { ринг } \\ \text { Block } & \text { блок } \\ \text { Absatz } & \text { абзац }\end{array}$

Бу ўзлашмалар ўзбек тилига кўчганда хеч қандай ўзгаришга учрамаган. Икки тилда хам ёзилиши ва айтилиши бир хил.

$\begin{array}{lc}\text { Hемисча } & \text { уузбекча } \\ \text { Buchhalter } & \text { бухгалтер } \\ \text { Hantel } & \text { гантел } \\ \text { Halstuch } & \text { галстук }\end{array}$

Бу ерда шуни айтиб ўтиш лозимки, немис тили сўзлари ўзбек тилига қанчалик тўғри кўчирилмасин, унда “ $h$ ” ундоши “г” ундошига ўзгартирилиб талаффуз қилинади ва яна бир қанча фонетик хусусиятларига кўра фарқ қилади. Бу хусусидаги мисоллар тахлили шуни кўсатадики, ўзлашма сўзларнинг имлоси кўпинча суффиксларга боғлиқдир. Бунда шу нарсани таъкидламоқ керакки, ўша фарқларнинг асосий қисми суффикслар зиммасига тушади.Суффикслар имло ва талаффуздаги юз берган ўзгаришларни фарқлаб, уларни қуйидаги гурухларга бўлиб ўрганиш мумкин:

Ортиқча суффикс қўшилган ўзлашмалар.Бу гурух ўзлашмаларга рус тилига қабул қилиниш жараёнида ортиқча қўшимчаларни олган ва шу кўринишида ўзбек тилига кириб келган сўзлар киради.Масалан: Mark- марка, Schacht -шахта. Бу ўзлашмалар фақат немис тилидан кириб келган сўзлар учун хосдир.

Суффикслари тушиб қолган ўзлашмалар. Бу гурухга рус тилида ўзлашиш жараёнида суффиксларни тушириб қолдириб, кейин шу холатда ўзбек тилига кириб келган ўзлашмалар киради. Масалан: Flotte - флот, Spritze - шприц.

Суффикслари ўзгариб ўтган ўзлашмалар. Ўзлашмалар суффикслари имло ва талаффузининг рус тилига ўзгариб ўтиш холлари хилма - хилдир. Масалан: Bund - бунт, Bord - борт, Schraube - шуруп, Pflug - плуг, hallo -алло, Vortuch -фартук, Kachel -кафел [ 3,54-55].

Айрим ундош товушларнинг артикуляцияси манба тилдагига қараганда қабул қилувчи тилда ўзларининг ифодаланиш ўрни ва усули билан фарқ қилади.Шунга ўхшаш холатларни ўзлашган сўзлардаги ундош товушлар хақида хам айтиш мумкин. Чунончи, ундошларнинг кучли, шовқинли ва қаттиқ айтилиши каби ўзига хос томонлари ўзбекча талаффуз қоидаларига мослашган.

Қўшма сўзлар айниқса немис тилида ўзига хос ходисадир. Қўшма сўзлар одатда икки компонентдан иборат, яъни аниқловчи ва аниқланмишли бўлади.Масалан: немисча Maßstab -масштаб қўшма сўзини оладиган бўлсак, бунда Stab - таёқ сўзи асосий сўз аниқланмишдир. Маß - ўлчов сўзи эса уни аниқлаб, унинг ўлчов таёғи эканлигини билдириб келаяпти. Бундай хусусият қўшма сўз учун бўлган ўзлашма - мисолларнинг хаммаси учун тегишлидир. Eis+berg - айсберг, Hals+tuch - галстук, Rück+sack - рюкзак, Kur+ort -курорт, Ballett+meister -балетместер [2,72].

Ўзлашмаларнинг рус ва ўзбек тилларидаги морфологик ўзгаришларига хулоса қилибшуни айтиш мумкинки, улар қабул қилувчи тилларда ўз морфологик хусусиятларини сақлаб қолиш билан бир қаторда, аввало, рус ва кейин ўзбек тилининг грамматик қурилиш қоидаларининг муайян таъсири остида маълум даражада қайта шаклланади.

Немис тилидан ўзбек тилига кириб келган сўзлардаги фонетик ўзгаришлар хусусиятларини хулосалаб шуни айтиш мумкинки, бу ўзлашмалар, аввало, рус тилида имло ва талаффуз жихатидан муайян шаклларни олган, кейин ўзбек тилига қабул қилинган. Фақат шундан кейингина ўзбек тилининг юқорида қайд қилинган орфографик ва орфоэпик қоидалар асосида ўзбек тили луғат таркибидан ўрин олган ва бирмунча мослашган.Бу жараёнда ўзлашмалардаги унлилар чўзиқ ва қисқалиги, кучли 
ва кучсиз айтилиши каби бир қатор ўзига хос хусусиятларини йўқотишган. Хатто улар ўзбек тилида манба тилдагига қараганда бутунлай бошқа товушлар билан ифодаланиб қабул қилинган.

Адабиётлар:

1. Жуманиёзов О. Ўзбек тилидаги герман тиллари ўзлашмалари. - Тошкент, 1987, 102 с.

2. Iskos A. Lenkowa A. Deutsche Lexikologie. -Moskau, 1970, S.296.

3. Langenscheidet. Power Wörtebuch Deutsch. - München, 2009. S.1122.

\section{ХУДОЖЕСТВЕННЫЙ ТЕКСТ КАК ОСНОВНОЙ КОМПОНЕНТ В ИЗУЧЕНИИ ИНОСТРАННОГО ЯЗЫКА И КУЛЬТУРЫ}

\section{Атауллаева Дилфуза Азизовна cm.npen. СамГИия E-mail: dilallia@mail.ru}

Annotation: The emergence and the development of foreign language learningteaching have clearly a deep history. During this process, several new methods have been emerged and they have been used in foreign language teaching. One of these documents is the literary text. In this study, we talked about the place of literary texts in the methods of FFL and examined their function and purpose in the methods. As a result it is possible to say that the literary text has an important place as a teaching material in foreign language teaching.
Key words : french foreign language, method, language teaching, literary text.

История преподавания и изучения иностранных языков сильно изменилась. Политические, экономические, технологические и социокультурные события сыграли решающую роль в появлении новых методов в процессе обучения иностранному языку. Можно сказать, что преподавание и изучение иностранного языка преследует разные цели в каждый период истории методов.С 2000-х годов в преподавании иностранных языков в Европе появился новый метод: перспективный метод.

В начале 21-го века технологическое, политическое, социальное, культурное развитие и потребностистудентов, изучающих язык меняются и растут день ото дня. Эта перспектива требует иного подходак учету новой социальной цели, связанной с прогрессом европейской интеграции, которая заключается в подготовке учащихся не только к жизни, но и к работе в их собственной стране или в другой стране, с представителями разных иностранных языков и культур. Это уже не просто общение, а диалог с носителем другого языка [1,4]. И поэтому преподавание иностранного языка имеет новую цель: а именно, мы рассматриваем учащихся как социальных актеров, которые выполняют коммуникативные задачи, включающие в себя навыки понимания и устного выражения.

Использование литературных текстов в процессе обучения является следствием новых направлений в области преподавания языка.Художественный текст играет важную роль в преподавании и изучении французского языка как иностранного, хотя в некоторых методах обучения FLE,к сожалению,он не рассматривается. Учащийся, изучающий иностранный язык, должен изучить не только язык, но и культуру этого языка. Поэтому неизбежно, что литературные тексты, являющиеся основным компонентом культуры, занимают важное место в преподавании иностранного языка.

В традиционных методах, целью литературный текст, являлось обучение половины $\mathrm{XX}$-го века с использованием обучения иностранному языку через литературе целевого языка.Со второй аудио-устных и визуальных методов 
большое значение придавалось изучению повседневного языка с использованием подготовленных документов(диалогов, писем, объявлений), направленных на совершенствование навыков общения. В 1980-х годах, с появлением коммуникативного метода, литературный текст в учебникаX FLE был представлен как аутентичный документ.Разнообразие целей и задач, поставленных перед учебной литературой, впечатляет: развитие аналитического мышления, развитие языковых навыков, развитие навыков чтения и письма, обогащение знаний по литературе, развитие культурного мышления, развитие эстетическоговоображения и наконец, участвует в формировании его личности.

Лазар подчеркивает, что в преподавании иностранного языка необходимо использовать литературный текст, поскольку он:

- мотивирует.

- является аутентичным документом.

- имеет образовательную ценность.

- можно найти во многих учебниках по изучению языка.

- помогает учащимся понять целевую культуру.

- является импульсивной силой для изучения иностранного языка.

- развивает у учащихся навыки интерпретации.

- развивает лингвистическую осведомленность учащихся .[2,2]

Таким образом, использование литературного текста в методах обучения языку является интересным инструментом обучения. Он является прекрасным отражением литературы и культуры страны изучаемого языка. При введении литературного текста в процесс обучения, необходимо соблюдать принцип прогрессии. Начиная с простых упражнений, мотивирующих учащихся, постепенно повышая объем и сложность текста.Не следует забывать и то, что литературный текст должен быть средством, а не целью достижения цели при изучении иностранного языка.

\section{Литературы:}

1. Conseil de L'Europe, (2000). Le Cadre Commun de Référence Pour Les Langues, Didier.

2. Lazar, G. (1993). Literature and Language Teaching: A Guide for Teachers and Trainers, Cambridge University Press, London.

3. Peytard, J. (1982). La Littérature et Classe de Langue, Paris, Hatier/Credif, collection LAL.

4. Puren, C. (1988). Histoires des Méthodologies, Clé International, Paris.

\section{КОМПАРАТИВ ФРАЗЕОЛОГИК БИРИКМАЛАРНИНГ ЛЕКСИК, СЕМАНТИК ВА СТИЛИСТИК ХУСУСИЯТЛАРИ}

\section{Самарқанд Давлат Архитектура ва Курилиш Институти ўқитувчиси}

Annotation: This article illustrates the grammatical, semantic, structural aspects of the layer of composite phraseological units in French phraseology , as well as some examples of phraseological units used in French.

\section{Key Words:} компоратив, муқояса, абстракт, муқояса объекти, муқояса субъекти.

Хар бир тилда одамлар нарса ва ходисалар дунёсига нисбатан ўз муносабатларини образли, хиссий таъсирчан, хаяжонли тарзда ифода этиш мақсадида турли-туман муқоясага асосланган лисоний воситалардан фойдаланадилар. Тасвирланаётган шахс, нарса, хислат-хусусият, воқеа -ходиса ва табиат манзаралари 
кўпинча муболағали(метафорали) тарзда тингловчига яхши таниш бўлган образлар билан муқояса қилинади. Натижада тасвир янада ойдинлашади, ифоданинг образлилиги ошади, юқори таъсирчанлик ва хиссий туйғу вужудга келади.

Бадиий муқояса одатда муқояса субъекти, мукояса объекти, хамда муқоясани вужудга келтирувчм белги-аломатлар асосида яратилади. Бошқача айтганда, муқоясанинг биринчи компоненти(субъект) ўзининг асосий маъносида қўлланилиб, иккинчи компоненти (объект) эса муқояса нимага қиёсланаётганини билдирувчи сўздан иборат бўлади . Бундай тил воситалари компоратив фразеологик бирликлар деб юритилади.

Француз тили фразеологиясида компаратив фразеологик бирликлар катта қатламни ташкил қилади. Бундай фразеологик биликларнинг грамматик,семантик структураси қатор хусусиятлари билан бошқа типдаги фразеологизмлардан ажралиб туради. Мантиқан олиб қараганда компаратив фразеологик бирликларнинг вужудга келиши одамларнинг абстракт фикрлашларининг оғзаки ва ёзма нутққа кўчган лисоний натижасидир.

Р.А.Будагов компаратив фразеологизмларнинг мантиқий ва лисоний аспектлари хақида гапириб «бизнинг абстракт фикрлашимиз натижасида мантиқий категориялвар хосил бўлади ва улар нутқ жараёнига кўчиб тил категорияларига айланади» деганида мутлоқ хақ эди Бундан лисоний категориялар турли тиллларда қандай ўзига хос тушунчалар ифода этишларидан қатъий назар барча тилларда учрайдиган категориядир, деган хулосага келиш мумкин. Дархақиқат хар қандай тил турли муқоясага асосланган образли ибораларга бой бўлади. Уларни одатда стилистиканинг тропалар бўлимида ўрганилади ва бир предмет , нарса ёки ходисани иккинчи бир нарса предмет, ходисага қиёсланиши, яъни турли компонентларнинг бирикуви асосида пайдо бўлади.

Француз тили компаратив фразеологлик бирликлари қуйидаги компонентлардан ташкил топади:

1.Қиёсланадиган предмет, нарса, воқеа номини ифодаловчи компонент. Бу компонент бошқа компонентларга нисбатан субъект вазифасини бажаради.

2.Қиёслашда таянч восита вазифасини бажарувчи компонент. Бу компонент одатда образ яратувчи сўз воситасини бажариб у муқоясанинг объекти дейилади.

3.Объект ва субъектни(биринчи ва иккинчи компонентни) ўзаро бириктирувчи қиёсловчи боғловчи.

4.Субъект ва объектнинг умумий белгиларини ифодаловчи, уларнинг ўртасида ишлатилувчи воситачи компонент.

Масалан: «uneplainevastecommelamer» компаратив бирлигида «uneplaine» сўзи субъект вазифасини, «vaste» компоненти субъект ва объектнинг умумий белгисини ифодаловчи воситачи компонент вазифасини, «сотme» - қиёсловчи боғловчи вазифасини ва «lamer» объект вазифасини бажараяпти.

Компаратив фразеологик бирликни нутқ жараёнида қўллаш учун унинг биринчи компоненти (субъекти) бўлиши зарур. Аммо бу субъект доимий бўлмаслиги, бошқа сўзлар билан осонгина алмаштирилиши мумкин.Бу субъектни материал ифодалаш доим ўзгариб туришидан далолат беради, объект эса доимий, яъни ўзгармай қолаверади. Масалан, юқоридаги компоратив бирликнинг субъекти хисобланмиш «uneplaine»компонентини осонгина бошқа от билан алмаштириб янги компаратив фразеологик бирлик хосил қилиш мумкин:

Un horizon vaste comme la mer,

Des terresvastes comme la mer ва х.

Субъект компонентнинг бундай алмаштирилиши объект ифодалаган маънонинг функционаллигига, лексик-семантик хусусиятларига умуман таъсир қилмайди.Чунки улар орасида мустахкам мантиқий (логик) боғланиш мавжуд- улардан бири 
иккинчисига хам характерли. Умумий булган белгини ифодалаб келяпти. Шу сабабли образли қиёслашлар тил бирлиги сифатида икки компонентли хосилалар хисобланади ва улардан биринчиси иккинчисига хам дахлдор бўлган белгиларни, хусусиятларни ифодалаб келади.

Француз тилида образли қиёслашларнинг компонентлар tel, aussi. que, autant...que, plus...que, moins ...que сингари боғловчилар билан бирикади. Бироқ қиёсий компаратив бирликларнинг вужудга келишида энг кўп қўлланиладигани comme боғловчисидир. Айнан шу боғловчи ёрдамида кўплаб компаратив фразеологик бирликлар яратилганлиги кузатилади.. Аммо таъкидлаш жоизки comme боғловчиси билан ясалган барча бирликлар фразеологик бирликлар хисобланавермайди, балки муайян муаллиф томонидан яратилган, тилда турғинлик касб этмаган индивидуал компаратив иборалар хисобланади. Демак биз образли компаратив фразеологик бирликларнинг семантик структурасидаги ўзига хос хусусиятларни ўрганиш учун дастлаб уларни бир хил грамматик структурага эга бўлган оддий қиёсий иборалардан фарқини ўрганишимиз лозим.

\section{Адабиётлар :}

1.БудаговР.А. Сравнительно-семасиологическиеисследования (романскиеязыки) М.,1963.

2. Гак В.Г. О структурно-семантических гоуппах во французской фразеологии. «Иностранные языки в школе», 1959, №5.

3.Гак В.Г. Беседы о фпаецузском слове. М., 1966.

4.Горбачевич К.С. Об историко- этимологических справках в фразеологическом словаре. Проблемы фразеологии.М.,1962.

5.Костелянц Б.Л. Французские нородно-разговорные фразеологизмы и их перевод на русский язык. Вопросы французской филологии. Труды МГПИ . М.,1972.

6. Левит 3.Н. Фразеологизмы как единицы языка. (к проблеме фразеологизма и свободного словосочетания) Тезисв докладов конференции»Язык и речь» М.,1962.

7.Ляндо Р.Л. К вопросу об отличии вариантов фразеологических единиц от синонимических фразеологизмов в совремеенном французском языке. Уч. записи МГПИ. Вопросы французской филологии, 1962, т.183.

8.Ляндо Р.Л. Лексические варианты глаглльных фразеологических единиц всовременном французском языке. Воронеж, 1965.

9.Мопассан Ги де.Новеллы.М.,1978.

10.Мопассан Ги де .Хаёт.Азизим.Новеллалар. Т.., 1983.

11. Мосьяков А.Е. Стилистические функции фразеологизмов всовременном французском языке. M., 1971.

12. Назарян А.Г. Образные сравнения французского языка. М.,1965.

\section{НЕМИС ТИЛИДА АN ПРЕДЛОГИ ИЛОВАЛИ ЭЛЕМЕНТ ФУНКЦИЯСИДА}

\section{Бегматов Қувончбек Мухторович \\ Самарқанд давлат чет тиллар институти ўқитувчиси}

Annotation: The article discusses in detail the features of the elements used, which are expressed by the German preposition an. The functions of the preposition an as an attached element are analyzed in the interpretation of examples taken from the literature.
Key Words: preposition an, attachable element, attachment design, mono- and multifunctionality.

An предлоги билан ифодаланиб келган иловали элементларни, уларга хос бўлган айрим хусусиятларни эътиборга олган холда икки гурухга бўлиб ўрганишни ўринли деб хисоблаймиз.

a) an предлоги бир вақтнинг ўзида хам асосий ифодада ва хам иловали элемент таркибида такрорланиши мумкин: 
1. Kann doch sein, sie versteht das, weil sie das selber schon gemacht hat

Nicht nur an sich gedacht. Auch mal an die anderen [Otto Herbert 1972: 195].

2. Du sollst an dich selber glauben und an keinen Geist oder so was. An dich selber und daß du einen Kopf hast, mit dem du sehen kannst, was in der Welt gespielt wird [Otto Herbert 1972: 142].

An предлоги билан ифодаланиб келувчи иловали элементларнинг тахлили асосида уларнинг функциясига хос бўлган яна бир хусусиятни

№2- рақамли мисолда берилган иловали элемент намунасида кўрсатишни маъқул топдик. Иловали элементларга хос бўлган хусусиятлардан яна бири уларнинг моно- ва полифункционаллигидир. Лекин шу холатни бу ерда хам кузатиш мумкин: бунда иловали элементни бир неча қисмга, аниқроғи тўртга бўламиз. Улардан an dich selber етакчи, қолганлари эса унга тобе, чунки иловали элементнинг етакчи қисмини тўлдириш мақсадида -und daß du einen Kopf hast қисми, шунингдек, бу қисмни тўлдириш мақсадида mit dem du sehen kannst қисми ва уни тўлдириш мақсадида энг охирги қисм -was in der Welt gespielt wird юзага келади. Натижада, етакчи қисм билан тобе компонентлар орасида кетма-кет синтактик боғланишли коммуникатив бирлик юзага келади, чунки бу коммуникатив бирликлар ўзаро хам мазмуний, хам мантиқий боғлангандир. Шулардан етакчи компонент an dich selber икки хил функцияда келади: асосий ифода булмиш - du sollst an dich selber glauben -учун иловали элемент функциясида; тобе компонентлар бўлмиш- und daß du einen Kopf hast, mit dem du sehen kannst, was in der Welt gespielt wird -учун асосий ифода функциясида келади. Иловали элементларнинг илова конструкция таркибида бажариб келаётган полифункционаллиги тўғрисида Б.Т. Турсунов куйидагича мулохаза юритади. "Иловали элементларнинг полифункционаллиги, унинг хозирги вақтгача кун тартибига қуйилмаган мхаммоларидан биридир. Шу сабабли бу мавзу алохида олинган илмий тадқиқот ишининг объекта бўлиши мумкин” [Турсунов 1993: 414 ва ундан кейин]. Хақиқатдан хам бу мулохаза жуда хам қизиқарли, ва тилшунос олимларнинг диққат эътиборини ўзига тортадиган масалалардандир. Лекин, бу мхаммо тўғрисида ушбу ишимизнинг кейинги қисмларида батафсилроқ фикр юритамиз.

An предлоги билан ифодаланиб келувчи иловали элементларга хос бўлган яна бир хусусият, ана шу аn предлогининг тушириб қолдирилиши:

Er dachte auch an seine Schwester. Auch Gottes Fingerzeige [Bruns Marianne 1972: 118].

Демак, an-ни иловали элемент таркибида туширилиб қолдирилиши, шу предлог билан ифодаланиб келаётган иловали элементлар тўғрисида мавжуд бўлган фикримизни ўзгартирмайди, аксинча, у худди шу ап-предлоги ёрдамида келувчи иловали элемент эканлигини яна бир бор таъкидлайди. Иловали элементлар таркибида содир бўлаётган бундай ўзгаришлар ўзидан-ўзи эмас, балки аниқ мақсадлар билан бевосита боғлиқ бўлиши мумкин. Ёзувчи тасвирланаётган воқеа-ходисаларни китобхонга аниқ етказиш, таъсирчанлигини ошириш мақсадида мавжуд бўлган хилма хил усуллардан фойдаланади. Ана шундай усуллардан бири иловали элементнинг ўзи бўлса, иккинчиси эса унинг таркибида aㅡ предлогининг тушириб қолдирилишидир. An нинг бу ер да тушириб қолдирилиши иловали элементнинг бажариб келаётган функциясига хеч қандай зарар етказмайди, чунки матн доирасида мавжуд бўлган вазият билан тўлдирилади. Илова конструкция атрофида содир бўлаётган бундай ўзгаришларни В.Н. Стрельцов “Илова ходисаси тил факторларини тежаш усулларидан биридир" [Стрельцов 1981: 81] дейди.

Натижада, иловали элементлар етакчи гап таркибида туширилиб қолдирилган компонентни тўлдириш, тиклаш мақсадида намоён бўлибгина қолмасдан, балки уларнинг ўзи хам шу асосий ифода таркибида келувчи компонентлар ёрдамида тикланиши мумкин деган хулосага эга бўламиз. Демак, ўзаро боғлиқлик илова конструкция компонентларига хос бўлган яна бир мухим хусусиятни, яъни асосий ифода билан иловали элементлар ўртасидаги синтактик-семантик боғлиқликни яна бир бор исботлайди.

\section{Адабиётлар:}

1. Маргарян А.А. О семантике падежей. Лингвистическая интерпретация специального текста и активизация обучения иноязычному общению. Материалы международной теоретической 
конференции. 28-30 сентября 1998 г. Самарканд, Изд-во СамГУ, 1998. -с. 103-106.

2. Стрельцов В.Н. Явление парцелляции как проявление принципа экономии в языке. Сб. Вопросы синтаксиса сложного предложения. Иркутск.1981. -с. 81- 89.

3. Турсунов Б.Т. Присоединение как особый тип синтаксической связи. Докт. дисс. Санкт-Петербург, 1993. -465 c.

4. Bruns Marianne. Die Lichtung. Mitteldeutscher Verlag Halle(Saale) 1972.460.

5. Herbert Otto. Zum Beispiel Josef. Aufbauverlag Berlin und Weimar, 1972, 285 S.

\section{КОГНИТИВНЫЙ СЦЕНАРИЙ В РАМКАХ ХУДОЖЕСТВЕННОГО ПРОСТРАНСТВА И ВРЕМЕНИ}

\section{преподаватель Самаркандский Государственный Институт Иностранных Языков E-mail: muhabbatyusupova1990@gmail.com}

Annotation: Cognitive scenario, or script, is one of the key concepts in cognitive linguistics and has its own characteristics of implementation in a literary text. This article discusses the implementation of scripts in the text within the framework of literary time and space.
Key Words:

cognitive linguistics, script, cognitive scenario, spacetime parameters

«Когнитивная лингвистика - активно развивающееся лингвистическое направление, во многом определяющее лицо современной мировой лингвистической науки» [Попова 2007: 3]. Она занимается когницией в ее непосредственной связи с языком. В связи с этим, следует помнить, что язык является одной из самых важных составляющих человеческого сознания, центром всей когнитивной деятельности. В нем находят свое выражение все когнитивные процессы и способности. В то же время язык это особая система, которая обеспечивает осуществление этих процессов и способностей. Эта взаимосвязь когнитивных и языковых структур конкретизируется в виде отдельных вопросов о языке и восприятии, языке и образном мышлении, языке и сознании, языке и памяти в зависимости от того, с какой когнитивной составляющей имеет дело исследователь и роль какой когнитивной составляющей он хочет изучить или описать более подробно. Главный вопрос - как отражено в сознании человека его понимание и видение мира. Если раньше постановка данной проблемы ограничивалась, в основном, областью мышления, то в настоящее время выясняется, что структуры знания чрезвычайно разнообразны и включают широкий спектр единиц. В современной когнитивной науке они часто называются разными форматами знания. Наряду с простыми понятиями, или концептами, выделяются и более сложные структуры: сцены, сценарии, эпизоды, фреймы, прототипы, пропозиции и другие форматы знания. Цель когнитивной лингвистики и заключается в том, чтобы посредством постижения языка проникнуть в формы этих структур и описать существующие между ними и языком зависимости.

Когнитивный сценарий, или скрипт, является одним из ключевых понятий когнитивной лингвистики. В отличие от статического концепта, сценарий носит динамический характер и традиционно отражает стереотипные обыденные процессы.

Наиболее часто встречающимися сценариями во французских художественных текстах являются сценарии из бытовой жизни: прием пиши, поход в театр, неизбежные ссоры и т.д. 
Сценарии могут быть как свернутыми, так и развернутыми. Говоря о свернутости и развернутости сценариев, следует упомянуть о таких понятиях как художественное пространство и время.

Художественное пространство и время (или хронотоп) - пространство и время, изображенные писателем в художественном произведении; действительность в ее пространственно-временных координатах.

Известно, что ощущение времени для человека в разные периоды его жизни субъективно: оно может растягиваться или сжиматься. Такая субъективность ощущений по-разному используется авторами художественных текстов: мгновение может длиться долго или вовсе остановиться, а большие временные периоды промелькнуть в одночасье. Художественное время - это последовательность в описании событий, субъективно воспринимаемых. Такое восприятие времени становится одной из форм изображения действительности, когда по воле автора изменяется временная перспектива. Причем временная перспектива может смещаться, прошедшее мыслиться как настоящее, а будущее предстать как прошедшее и т.п.

Художественное пространство - это континуум, в котором действуют персонажи и совершаются действия.

Художественное пространство не есть пассивное вместилище героев и сюжетных эпизодов. Соотношение его с действующими лицами и общей моделью мира, создаваемой художественным текстом, убеждает в том, что язык художественного пространства - не пустотелый сосуд, а один из компонентов общего языка, на котором говорит художественное произведение.

Лотман в своем исследовании на примере «Старосветских помещиков» Н.В. Гоголя выделяет внутреннее и внешнее пространство персонажа и называет их внутренним и внешним миром. Внутренний мир характеризуется отгороженностью, категорией «свое», а внешний - обширностью, неопределенностью и категорией «чужое».

Пространство, взятое само по себе, может быть амбивалентно: может соединяться и с величием и с пошлостью. Для того чтобы стать возвышенным, пространство должно быть не только безграничным, но и направленным, находящийся в нем должен двигаться к цели.

Пространство может быть большим, охватывать ряд стран (в романе путешествий) или даже выходить за пределы земной планеты (в романах фантастических и принадлежащих к романтическому направлению), оно может также сужаться до тесных границ одной комнаты. [Лихачев 1979: 335]. Пространство, создаваемое автором, может обладать своеобразными географическими свойствами: быть реальным (как в летописи или историческом романе) или воображаемым (как в сказке).

Пространство в словесном искусстве непосредственно связано с художественным временем, оно динамично. Пространство создает среду для движения и само меняется, движется.

Время отвоевывает и подчиняет себе все более крупные участки в сознании людей. Литература в большей мере, чем любое другое искусство, становится искусством времени. Время - его объект, субъект и орудие изображения. Сознание и ощущение движения и изменяемости мира в многообразных формах времени пронизывает собой литературу.

Художественное время - это не взгляд на проблему времени, а само время, как оно воспроизводиться и изображается в художественном произведении. Именно исследование этого художественного времени в произведениях, а не исследование концепций времени, высказываемых теми или иными авторами, имеют наибольшее значение для понимания эстетической природы словесного искусства. 
Художественное время - явление самой художественной ткани литературного произведения, подчиняющее своим художественным задачам и грамматическое время, и философское его понимание писателем.

Произведение искусства слова развертывается во времени. Время нужно для его восприятия и для его написания. Вот почему художник-творец учитывает это «естественное», фактическое время произведения. Но время и изображается. Автор может изобразить короткий или длинный промежуток времени, может заставить время протекать медленно или быстро, может изобразить его протекающим непрерывно или прерывисто, последовательно или непоследовательно (с возвращением назад, с «забеганием» вперед и т. д.). Он может изобразить время произведения в тесной связи с историческим временем или в отрыве от него - замкнутым в себе; может изображать прошлое, настоящее и будущее в различных сочетаниях.

Художественное время в отличие от времени объективного данного использует многообразие субъективного восприятия времени. Ощущение времени у человека, как известно, крайне субъективно. Оно может «тянуться» и может «бежать». Мгновение может «остановиться», а длительный период «промелькнуть». Художественное произведение делает это субъективное восприятие времени одной из форм изображения действительности.

Ярким примером тому является роман ирландского писателя Джеймса Джойса «Улисс». Действие романа в несколько сотен страниц занимает один день. Подробнейшим образом рассказывается о каждом поступке, каждой мысли и чувстве всех главных героев с момента пробуждения до их отхода ко сну.

За этой простой поверхностью повествования понемногу проступают другие планы автора.

Замысел Джойса в "Улиссе" - "увидеть все во всем". Один обычный день превращается в эпическое повествование об истории древнейшей из европейских столиц - Дублина, о двух расах, ирландской и иудейской, и одновременно в изображение всей истории человечества, в своего рода энциклопедию человеческого знания и в конспект истории английской литературы. Реалистическую определенность времени и пространства Джойс сохраняет лишь на поверхности повествования. Поскольку основное действие разыгрывается в сознании героев, время и пространство в романе приобретают универсальный характер: все происходит одновременно и все проницает друг друга.

Время в художественной литературе воспринимается благодаря связи событий причинно-следственной или психологической, ассоциативной. Время в художественном произведении - это не только и не столько календарные отчеты, сколько соотнесенность событий. В литературе есть свой «принцип относительности». События в сюжете предшествуют друг другу и следуют друг за другом, выстраиваются в сложный ряд, и благодаря этому читатель способен замечать время в художественном произведении, даже если о времени в нем ничего специально не говорится. Где нет событий, нет времени: в описаниях статических явлений, например, в пейзаже или портрете, характеристике действующего лица, в философских размышлениях автора.

Что же касается сценариев, естественно, что им тоже присуща пространственновременная характеристика. Один и тот же сценарий можно реализовать одним словом, но можно также развернуть его на 50 и более страниц. Так, следующий текст:

Ce premier dîner fut très gai. [Sagan, 2000: 65].

- является свернутым сценарием. Мы видим сжатие реального времени и его превращение в художественное. В этом случае автор не видит никакой необходимости описывать подробно сценарий. Его цель - просто сообщить читателю о том, что ужин прошел очень весело. 
В случае же развернутого сценария чаще всего описание деталей сценария является не самоцелью для автора. Это лишь фон, на котором автор реализует свои идеи, к примеру, рисует образ героев, раскрывает их характер, или же показывает их настроение, внутреннее состояние.

Рассмотрим фрагмент художественного текста, который можно охарактеризовать как реализацию сценария обеда, ср.:

Mais c'était surtout aux heures des repas qu'elle n'en pouvait plus, dans cette petite salle au rez-de-chaussée, avec le poêle qui fumait, la porte qui criait, les murs qui suintaient, les pavés humides ; toute l'amertume de l'existence, lui semblait servie sur son assiette, et, à la fumée du bouilli, il montait du fond de son âme comme d'autres bouffées d'affadissement. Charles était long à manger ; elle grignotait quelques noisettes, ou bien, appuyée du coude, s'amusait, avec la pointe de son couteau, à faire des raies sur la toile cirée. [Flaubert, 1910: 95]

Читатель распознает сценарий благодаря ключевым словам, относящимся к принятию пищи: repas, le poêle qui fumait, servie sur son assiette, la fumée du bouilli, manger, noisettes, couteau. Видна также и повторяемость действия: aux heures des repas.

Показ деталей сценария обеда как такового не является целью для автора. Пользуясь сценарием, Флобер хотел показать читателю внутренние переживания героини, ср.: toute l'amertume de l'existence, lui semblait servie sur son assiette. Кроме того, автор использует сравнение для того, чтобы показать читателю внутренние чувства героини, ср.: à la fumée du bouilli, il montait du fond de son âme comme d'autres bouffées d'affadissement.

Из вышеизложенного можно сделать вывод о том, что время и пространство являются естественными формами существования изображенного в произведении мира. Эта действительность в ее пространственных и временных координатах присутствует и в сценарии. Пространственно-временная организация сценария в большей степени подчинена художественной задаче. Пространственные и временные ориентиры необходимы для того, чтобы не нарушать целостность восприятия текста читателем.

\section{Литературы:}

1. Попова З.Д., Стернин И.А. Когнитивная лингвистика. - М.: АСТ - Восток-Запад, 2007. - 314 с.

2. Лихачев Д.С. Поэтика древнерусской литературы. М.: Наука, 1979. - 360 с.

3. Краткий словарь когнитивных терминов. Сост. Е.С. Кубрякова, В.З. Демьянков, Ю.Г. Панкрац, Л.Г. Лузина; под общ. ред. Е.С. Кубряковой. - М.: МГУ, 1997. - 197 с.

4. Sagan F. Bonjour tristesse. - Edition Julliard, 2000

5. Flauber G. Madame Bovary, Louis Conard, Paris, 1910

\section{ЎЗБЕК ТИЛШУНОСЛИГИДА ЛИНГВОКУЛЬТУРОЛОГИЯ ФАНИНИНГ ЎРГАНИЛИШ ТАРИХИ ВА ЎРНИ}

Annotation: This article gives a brief overview of the history of the introduction of linguoculturology to Uzbek linguistics. There is also information about some work done in Uzbek linguistics in this regard.
Искандарова Мавлуда Абдулла Қодирий номидаги ижод мактаби ўқитувчиси

Key Words: lingvoculturology, linguistics, council, research, analogy, speech, speech communication, method, new approach and so on.

Маълумки, яқин йилларгача замонавий тилшуносликнинг йўналишлари хисобланган систем тилшунослик, структур тилшунослик когнитив тилшунослик, социолингвистика, лингвопрагматика, прагмалингвистика, нейролингвистика, психолингвистика, лингвокультурология сингари фанлар билан асосан Европа ва Америка тилшунослари шуғулланар эди. Бу фанлар нафақат Ўзбекистонда, балки Собиқ Иттифоқ худудида ўрганиш ва тадқиқ этиш мумкин эмас эди. Чунки коммунистлар 
хукмронлик қилган мамлакатда ғарб тилшунослари ютуқларидан фойдаланиш қаъий ман этилган эди. Уларга нисбатан “буржуа тилшунослиги” сифатида қаралиб, шўролар тилшунослигида ўрганиш ва тадқиқ этиш тақиқланган эди.

Собиқ Иттифоқ, хусусан, Ўзбекистон худудида қайта қуриш, демократия шабадалари эса бошлагач, тилшуносликда хам туб бурилишлар юз бера бошлади. Мустақиликка эришилгач, дунё тилшунослигида бўлаётган янгиликлар ва янги тадқиқот методлари хам ўзбек тилшунослигига жорий этила бошлади. Аста-секинлик билан анъанавий методлар ўрнини замонавий метод ва усуллар эгаллай бошлади.

Биз ушбу мақоламизда лингвокультурология фанининг ўзбек тилшунослари томонида тадқиқ этилиш тарихи ва бугунги холати ва айримлари тўғрисида фикрларимизни баён қилишга харакат қиламиз.

Ушбу ўринда масаланинг бир томонини хам қайд этишни ўринли, деб хисоблаймиз. Мустақиллик давригача, замонавий тилшуносликларнинг ютуқларини ўзбек тилшунослигига жорий этиш маълум маънода чекланган бўлса-да, олимларимиз анънавий методлар билан бўлса-да,замонавий тилшунослик методларига хос назарий фикрларни баён этишган ва уларни тадқиқ этиш юзасидан тавсияларни хам имкон даражада ишлаб чиқишга харакат қилишган. Хусусан, хозирги пайтдатилшунослигимизда оммалашиб кетаётган лингвокультурология масалалари билан(гарчи бошқача терминлар номи остида бўлса-да) Ш. Шоабдурахмонов, Р. Қўнғуров, А. Рустамов, М. Миртожиев, Н. Махмудов, Б. Йўлдошев, С. Йўлдошева сингари захматкаш олимларимиз томонидан турли номлар остида она тилимизнинг лингвомаданий бирликлар тўғрисида ўринли ва мулохазали фикрлар билдирилганлиги тахсинга лойикдир.

Мустақилликдан кейин Н. Махмудов, А. Нурмонов, Х. Неъматов, М. Миртожиев, Ш.Сафаров, Б. Йўлдошев, Х. Шамсиддинов, А. Маматов, Б. Менглиев, Ш. Усмонова, Д. Худойберганова, С. Мўминов, М. Хакимов, М. Йўлдошев, 3. Холмонова, И. Болтабоева, Г. Қобулжонова, Ш. Махмараимова сингари тилшуносларимиз томонидан линвокультурология фанига оид монографик тадқиқотлар хамда ўқув қўлланмалари ва луғатлар яратилди.

Ш. Сафаровнинг бир қатор монографик тадқиқотларида нутқий мулоқотнинг прагматик, ижтимоий хусусиятлари, нутқий акт, нутқий мулоқот, лингвистик ходисаларнинг ўзаро мунособатлари сингари қатор масалаларнинг ечими ўз ифодасини топган[1.].

С.Мўминовнинг "Ўзбек мулоқот хулқининг ижтимоий-лисоний хусусиятлари"номли докторлик диссертациясида нутқий мулоқотнинг ўзига хос хусусиятларининг прагматик асослари ёритиб берилган[2.].

Д. Худойберганованинг “Ўзбек тилида бадиий матнларнинг антропоцентрик талқини” номли докторлик диссертациясида оммабоп ва бадиий матнда шахс рухий холатини ифодалашда ўхшатиш, жонлантириш, халқ мақоллари нутқий этикет оханг ва ассоциатив сўзлар сингарилар инсон рухий холатини ифодаловчи лингвомаданий бирликлар сифатида намоён бўлиши сингари масалалар кенг ва атрофлича ёритиб берилганлиги билан мухим ахамият касб этади[ 3 .].

Д. Худойберганованинг Н. Махмудов билан хамкорликда яратган “Ўхшатишларнинг изохли луғати"да ўхшатишларнинг лингвокультурологик хусусиятларини очиб берувчи лингвомаданий бирликларнинг изохи берилган бўлиб, у лингвокультурология билан шуғулланувчилар учун жуда фойдали қўлланма вазифасини ўташи табиийдир[4.]

Хуллас, ўзбек тилшунослигида лингвокультурология юзасидан анча-мунча тадқиқотлар яратилган. Аммо хали фанни янада кенгроқ ўрганиш ва тадқиқ этиш борасида ечимини кутаётган масалаларни янгича ёндошувлар асосида янада чуқурроқ ўрганиш тилшунослигимиз олдида турган долзарб масалалардан бири хисобланади.

\section{Адабиётлар:}


1. Сафаров Ш. Прагмалингвистика. - Тошкент: "Ўзбекистон миллий энциклопедияси". Давлат илмий нашриёти, 2000; Сафаров Ш.Прагмалингвистика. - Тошкент: "Ўзбекистон миллий энциклопедияси”. Давлат илмий нашриёти, 2008; Сафаров Ш.Семантика. -Тошкент: “Ўзбекистон миллий энциклопедияси". Давлат илмий нашриёти, 2013

2. Мўминов С. Ўзбек мулоқот хулқининг ижтимоий-лисоний хусусиятлари. ДДА. -Тошкент, 2000.

3.Худойберганова Д. Ўзбек тилида бадиий матнларнинг антропоцентрик талқини. ДДА.Тошкент, 2015.

4. Махмудов Н., Худойберганова Д. Ўхшатишлар изохли луғати.-Тошкент: Маънавият, 2006.

\section{現代カラカルパク語における同音異義語}

(Zamonaviy qoraqalpoq tilida omonimlar)

\section{アリ・カラジャノフ (Ali Kaljanov) 博士課程 \\ ウズベキスタン共和国科学アカデミー カラカルパク支部 \\ カラカルパク人文科学研究所 Email:alivxankaljanov@mail.ru}

Annotation: This article deals with the homonyms of the Key Words: modern Karakalpak language. The problems of Karakalpak homonyms and their solutions are also given. Again in this article, there are homonyms variants of the word (kók). The formation, classification, terminology, and comparativestudy of homonyms are discussed.

Homonyms,

Karakalpak

language, kók.

カラカルパク語の特徵の一つに、同音異義語がある。同一言語で、発音が同じで意 味の異なる 2つ以上の単語を同音異義語という。カラカルパク語の「kún（太陽）と kún

（日）」や「altın（金）と altın（親切）」がこれにあたる.

これまでカラカルパク言語学ではマロフ、バスカコフ、ベリヂムラトフ、ダウレト フ、クダイベルゲノフなどの研究者たちがカラカルパク語の同音異義語について様々な論 文やレポートを発表した。しかし、今日に至るまで、同音異義語が特別な点については研 究されなかった。カラカルパク言語学の同音異義語について様々な見解や報告が増えてき ている。その上、外国の学習者たちもカラカルパク語の同音異義語の困難に直面し、言語 習得に苦労している。以上が本研究の問題提起の背景である。

言語の理解する鍵は同音異義語である。カラカルパク語の同音異義語は日本語の同 音異義語より数が少ない。しかしそうだとしても、様々な問題が出てくる。この問題が以 下の通りである。

- 同音異義語の説明の問題

- 同音異義語の起源の問題

- 同音異義語の分類の問題

- 同音異義語の比較の問題

上記の問題はカラカルパク言語学だけではなく、世界中の言語学での問題である。 この同音異義語の問題が言語学での様々な部分に影響を及ぼしている。そのため、現代力 ラカルパク語における同音異義語を詳しく研究するべきだと考える。

現代カラカルパク語の同音異義語の中で一番多いのが「kók」という単語である。 その「kók」という単語の意味は以下の通りである。

「kók」- 空の色
「kók」- 空
「kók」- 草


「kók」ー カラカルパク人の伝統的な家の部分

「kók」一 体に残した傷跡

「kók」一生

「kók」ー ドルの言葉での意味

上の見た通りに「kók」という言葉には 7 同音異義語の意味がある。日本語では最も 同音異義語の多い言葉は「こうしょう」である。

結論としては、現代カラカルパク語での同音異義語は様々な点から研究する必要が ある。その上、本研究は始めてのカラカルパク語における同音異義語の研究なので、将来 的には前述の全部問題をそれぞれ研究したいと思う。

\section{参考文献}

1. Қ.Пахратдинов, Қ. Бекбергенов. Қарақалпақ тилиниң омонимлер сөзлиги. Нөкис. “QARAQALPAQSTAN". 2015, 32 бет

\section{FRANSUZCHA FRAZEOLOGIZMLARDA POLISEMIYA HODISASI VA ULARNING MA'NO ETIMOLOGIYASI}

\section{Doliyeva Laylo Buriboyevna Samarqand Davlat Chet Tillar Instituti o'qituvchisi Email:doliyeva@samdchti.uz}

Annotation: This article discusses the etymology of the meaning of the origin of French phraseological units. Phraseological polysemy is a phraseological unit that has twoor more lexical meanings. It is known that the phenomenon of phraseological polysemy is determined by studying the semantic properties of phraseological units.

Frazeologik polisemiya deganda frazeologik birlikning o'zi ikki va undan ortiq lug'aviy ma'no anglatishi tushuniladi. Ma'lumki, frazeologik polisemiya hodisasi frazeologik birliklarning semantik xususiyatlarini o'rgangan holda aniqlanadi.

Har qanday tilda ham frazeologizmlarining ko'pchiligi ikki yoki uch ma'noli, shuningdek to'rt ma'noli so'zlashuv turlari mavjud. Ko'p ma'noli iborada uning ma'nolari asosan biri ikkinchisidan ma'no olgan bo'ladi.Ya'ni ibora nechta ma'nodan tashkil topganiga qaramay, ma'nolar orasida bog'lanish, umumiylik seziladi.

Masalan:

Avoir le coeur sur la main

Ushbu ibora o'z navbatida uchta ma'noga ega, saxiy bo'lmoq, kasal bo'lmoq, yuragini bag'ishlamoq,taqdim qilmoq. Bu yerda saxiy bo'lmoq va yuragini bag'ishlamoq ma'nolari bir biriga bog'liq ekanligini ko'rshimiz mumkin. Bu kabi ko'p ma'noli iboralar har bir ma'nosi bilan boshqa boshqa ibora bilan sinonim bo'lib kela oladi

1) Etre généreux-saxiy bo'Imoq

2) Etre malade-kasal bo'lmoq

3) Faire don de son coeur-yuragini bag'ishlamoq

Dastlab bu ibora XVIII asrga borib taqaladi. Butun his-hayajonlar to'lqinlanadigan makon bo'lmish yurakka borib taqaladi, biror insonning sezgi va emotsiyalari yuragidan to'lib toshsa va buni boshqalarga ulashishga tayyor bo'lsa aynan ushbu insonlarga nisbatan saxiy qalbi pok ma'nosida ishlatilgan, bundan tashqari bunday insonlarning har doim mehnat bilan bandligini hisobga olib qo'li ish bilan band inson boshqalarga mehr-muruvvat va birdamlikni kuchli tarzda ifodalay olishi ma'nosini anglatgan, keyinchalik esa ushbu iborani yana ikkita alohida ma'nosi paydo bo'ldi, shulardan biri birinchi asl ma'nosi bo'lmish saxiy qalbi pok ma'nosiga sinonim bo'lgan Faire don de son coeur-yuragini kimgadir taqdim qilmoq, sof qalbli bo'lmoq 
ma'nosida. Bunga mutlaqo teskari ma'noda ushbu ibora ba'zi-bir hollarda Etre malade-kasal bo'lmoq tarzida kamdan-kam hollarda ishlatiladi. Shuning uchun ham bu iborada qo'l va yurak birgalikda tasvirlanadi. Masalan :

Ushbu iborada ham ma'no turlicha bo'lishiga qaramay, umumiy ma'no saxiy va ochiqko'ngil inson ma'nosida shakllanadi.0'zbek tilida bunday iboraga sinonim tarzda «qo'li ochiq», "o'ng qo'li doim ko'ksida» kabi iborlardan foydalaniladi.

Un froid de Canard

Ushbu ibora ham ikki ma'noga ega shiddatli shamol, tonggi shabada shamoli. Ammo, tonggi shaboda ma'nosi istemolda keng qo'llanilmaydi. Har ikkala ma'nosida 1) Froid intense, 2)Froid de petit matin iboralariga ma'nodosh holda ishlatiladi.

Ushbu iboraning paydo bo'lishi XIX asr oxirlariga borib taqaladi. Balkim uning ma'nosi kuchli shiddatli shamol ma'nosida va bunga asosiy sabab o'rdaklar ovi bilan bog'liq bo'lganligidir. Yana bir izohga ko'ra, o'rdaklar o'zining qattiq oyoqlari bilan suv ustidagi muzlarning tekis joyini teshadi va sovuq shamol bo'ladi, ya'ni ushbu ma'noga ko'ra o'rdaklar oyoqlari bilan qattiq shamol va muzlash olib keladi deya tarif beriladi.

Navbatdagi iborada ham ma'no aslida shamol so'zi atrofida mujassamlashadi.

Battre la campagne iborasi ham uchta asosiy ma'noga ega.

1) Harbiylar orasida dushman yerlarini bosib olish va razvedka qilish.

Parcourir la campagne pour reconnaître la position et les mouvements de l'ennemi

2) Ov jarayonini anglatib keladi hayvon va qushlarni ovlamoq

Parcourir le terrain de chasse des gibiers

3)Og'zaki nutqda ko'p gapirmoq ma'nosida ham qo'llaniladi. Vaysamoq, bo'lmag'ur narsalarni gapirib mavzudan uzoqlashmoq.

Ushbu ibora XIX asrda paydo bo'ldi va dastlabki ma'nosini ya'ni harbiy kontekstda dushman yerlarini razvedka qilmoq va bosib olmoq tarzida qo'llana boshladi. Keyinchalik esa bu iboraning ikkinchi ma'nosi bo'lmish yovvoyi hayvonlarni ov qilish ma'nosi paydo bo'ldi, aynan nega bunday ma'no olganiga aniq ma'lumot topilmagan. Hozirgi kunga kelib bu ibora to'liq shakllangan bo'lib,bu ibora o'zining ko'chma ma'nosida ya'ni vaysamoq, mavzudan uzoqlashmoq ma'nosida qo'llaniladi. O'z navbatida ushbu ibora polisemik maqomga ega bo'lib, uni konteksga qarab har uchala ma'noda ham bemalol ishlatish mumkin.

Ushbu iborada ma'no biroz boshqalaridan farq qiladi, ammo agar ushbu iboraning o'z ma'nosida harbiylar tilida va ov qilish ma'nosida ko'rib chiqadigan bo'lsak mazmuniy bog'liqlikni payqash qiyin emas, ikkala ma'noda ham umumiy asos ma'no bu-o'ldirmoq va vayron qilmoq hisoblanadi. Lekin bu iboraning ko'chma ma'nosi esa boshqalaridan ma'no jihatdan farqlidir.

Avoir, Donner l'eau à la bouche-

1) og'zini suvini oqizmoq, ishtahasini keltirmoq;

2) havasini keltirmoq.

Ushbu ibora XV asrdan buyon juda keng qo'llanilib kelinmoqda.Undagi ikkala ma'no ham aslida ma'nodosh bo'lib bir-biridan birozgina farq qiladi. Ibora tarixi haqida to'xtaladigan bo'lsak, qadimda oila davrasida stol atrofida ovqatlanishayotganda ayollar shirin va mazali yeguliklarni keltirganda erkaklar ularni yeyish oldidan hidlari dimog'iga urilib og'izlaridan suvlari kelib, ya'ni so'laklari oqib turgan holat eslanadi. Ushbu ma'no qayerdan paydo bo'lganiga yana bir sababni uzoqdan qidirish shart emas, professor Pavlov tomonidan o'rganilgan itlardagi so'lak bezlari tajribasi ham ushbu iborani ma'nosiga juda mos keladi. Ushbu iboraning ikkinchi ma'nosi bo'lmish, havasini keltirmoq ham aslida birinchi ma'noning kengayishi natijasida o'zgarib ketgan ekan.

O'z-o'zidan ma'lumki navbatdagi iboramizning ikkala ma'nosi ham aslida bir umumiy so'z doirasida aylanib turibdi, ya'ni «havasi kelmoq» ma'nosida. Bizda ham ushbu iboradan uzoqlashmagan holda "og'zini suvi oqmoq» iborasi aynan har ikkala holatda ham,ya'ni havas qilish ma'nosida ham,ishtahasi kelish ma'nosida ham qo'llanaveadi. 
Ko'p ma'nolilik, ya'ni ma'noning birdan ortiqligi, o'ziga xos bir biridan keskin farq qiluvchi ma'no anglatadi, ammo ba'zi bir fransuz iboralari o'tmishda juda keng qo'lanilgan bo'lib, ularning qaysidir ma'nolari hozirgi zamonga mos tushmay qoladi, yoki ishlatilish doirasi chegaralanib qoladi. Frazeologik birliklarda ma'no kengayishi, yangi ma'nolarning paydo bo'lishi tarixiy voqealarga, adabiyotda qo'llanilishi va til egalarining ularni keng qo'llashi bilan uzviy bog'liq holda shakllanadi deyishimiz mumkin. Dastlab asosiy bir ma'noda ishlatilib, vaqt o'tishi bilan qo'shimcha ma'nolarning paydo bo'lishi frazeologik birliklarning polisemik xususiyatlarga ega bo'lishiga turtki bo'ladi. Ularning ma'nolari bir biriga yaqin ham, umuman bir biridan farq qilishi ham mumkin. Biz fransuzcha nutqni, asarlarni to'g'ri anglashimiz uchun va bu kabi birliklarni nutqda qo'llashimiz uchun ularning ha bir ma'nosidan xabardor bo'lishimiz foydadan holi bo'lmaydi.

\section{Adabiyotlar :}

1. Gross Gaston : Les expressions figées en français (noms composés et autres locutions). Paris. Ophrys.-1996.

2. González Rey Isabel, La phraséologie du français, Toulouse, Presses Universitaires du Midi, -2015

3. Stéphanie M.-Le sens figuré, les expressions figées, la polysémie chez le jeune dysphasique. Comment accéder au sens second - 2010.

4. Nazaryan G.A. Фразеология современного французского языка. ВШ, -1987

\section{ТУРЛИ СТРУКТУРАЛИ ИЛОВА КОНСТРУКЦИЯЛАРНИНГ ЎЗИГА ХОС ГИНТАКТИК-С.ТИЛИСТИК ХУС.УСИТЛАРИ}

\section{Мамасолиев Икром \\ Самарқанд давлат чет тиллар институти ўқитувчиси Email:mamasoliev@samdchti.uz}

Annotation: This article is devoted to the study of specific syntactic-stylistic features of connecting constructions with various structures and regular semantic relations of the components, connecting them with each other.

Key Words: connecting constructions, attached element, syntactic-stylistic features, continuous character, main statement, component.

Узлуксиз ёки давомли характерга эга бўлган иловали элементлар деб бир ёки ундан ортиқ (бўлган) абзацлардан ташкил топган илова конструкциялар таркибида такрорланиб келувчи иловали элементларга айтамиз. Узлуксиз ёки давомли иловали элементлардан ташкил топган илова конструкциялар ва уларни ташкил қилувчи компонентлар ўзаро бир-бирлари билан доимо мазмуний алоқадорлик муносабатида бўлишади.

Бошқача қилиб айтганда, иловали элементлар қанақа структуравий кўринишга эга бўлмасин, улар доимо хам синтактик, хам семантик жихатдан бир-бирлари билан ўзаро боғланган ягона мураккаб синтактик бирликни намоён этади холос.

Фикримизнинг исботи учун узлуксиз ёки давомли характерга эга бўлган иловали элементларнинг тахлилига ўтайлик. Масалан:

1. Und dann waren sie allein. Luise umsorgte Bert wie immer mit umsichtiger Aufmerksamkeit. «Nie wieder darfst du mich verlassen. Nicht wegen der Leute. Bert. Sie mögen mit Fingern auf uns zeigen. Auch nicht wegen Oma und Qpa. Nur meinetwegen und des Kleinen wegen. Ich würde es ein zweites Mal nicht ertragen, das tut mir weh» [Reinowski 1972: 231].

Бу ерда илова конструкция бир-бири билан ўзаро мазмуний алоқада бўлган гапларнинг йиғиндисидан ташкил топган ягона абзацдан иборат. Бу илова конструкцияда тасвирланаётган воқеа-ходиса оила хаёти билан бевосита боғлиқ. Тасвирланаётган воқеанинг оила учун, оилани сақлаб қолиш учунм ухимроқ томонларини кўрсатиш мақсадида ёзувчи айрим синтактик фигураларга мурожаат 
қилади. Ана шундай синтактик фигуралар функциясида узлуксиз характерга эга бўлган иловали элементлар келади. Бу иловали элементлар генитив келишигини талаб қилувчи предлоглар ёрдамида ифодаланиб келади, структуравий жихатдан содда структуравий иловали элементлардир. Бироқ, буиловали элементлар содда структуравий иловали элементлар хисобланса-да, бири иккинчисидан ўзига хос прагматик хусусиятлари билан фарқ қилади. Масалан, илова конструкция таркибида жойлашиши жихатдан биринчи уцинда келувчи -nicht wegen der Leute. Bert. иловали элементи жойлашиши жихатдан шу матн таркибида иккинчи ўринда турувчи auch nicht wegen Oma und Opa, nur meinetwegen und des Kleinen wegen иловали элементидан унчалик кенгайиш хусусиятига эта бўлмаганлиги билан фарқ қилиб туради. Иккинчи иловали элемент биринчи иловали элементдан фақатгина структурасининг кенгайганлиги билан эмас, балки салмоқли, етакчи маъно англатиб келиши билан хам фарқ қилади. Унинг структураси генитив келишигини талаб қилувчи = wegenпредлогининг хам содда, хам мураккаб формада такрорланиб келиши билан хосил бўлади.

Иловали элементлар томонидан бутун бир матнга ёки асосий ифода функциясида келувчи компонентларга нисбатан билдирилаётган коммуникатив функциялар шу илова конструкцияни ташкил қилувчи синтактик бирликларнинг ўзаро стуруктуравий боғлиқлигини кўрсатибгина қолмасдан, уларнинг мазмуний боғлиқлигини хам акс эттиради. Бу хол тасвирланаётган воқеанинг узлуксизлигини, давомий характерга эга эканлигини кўрсатади. Луиза Берт билан сухбатни давом эттириб, сен мени хеч қачон ташлаб кета олмайсан, чунки биз оилани одамлар учун эмас, ота ёки она учун эмас, балки ўзимиз учун, боламиз учун қурганмиз, дейди.

Илова конструкция таркибида жойлашиш жихатдан иккинчи ўринда келувчи auch nicht wegen Oma und Opa, nur meinetwegen und des Kleinen wegen - иловали элемент ўзининг билдириб келаётган прагматик маъно хусусияти билан фақатгина ўзи бевосита боғлиқ бўлган асосий ифодага якун ясаб қолмасдан, балки шу абзацнинг структуравий ва мазмуний алоқадорлигига якун ясайди. Илова алоқага асосланган катта бир матн мазмуний жихатдан якунланади, чунки иловали элементларнинг прагматик маъно хусусиятлари бундай матнда хал қилувчи роль ўйнайди. Демак, иловали элементлар қандай структуравий шаклга, кўринишга эга бўлишмасин уларнинг маъновий хусусиятлари доимо хал қилувчи роль ўйнайди, сабаб улар доимо мантиқий урғуга эга бўлади.

Баъзи холлларда узлуксиз ёки давомли характерга эга бўлган иловали элементлар такрорлаш принципи асосида юзага келиши мумкин. Бундай холларда жойлашиш жихатидан иккинчи ўринда келувчи иловали элемент, жойлашиш жихатдан биринчи ўринда турган иловали элементни тўлиғича такрорлаши мумкин ёки бундай такрорланиш қисман содир бўлиши хам мумкин. Жумладан:

Wieder wandte sich Betsy um und sah Nickolas fest in die Augen.

«Wen der Ritter Lionheart töten wird, das weiß ich nicht. Einen von uns. Irgendeinen. Und wenn es dein Vater wahrmacht, daß wir am elften November noch einmal in das Kastell gehen müssen, dann sogar zwei. Zwei von uns. Vielleicht dich und mich, vielleicht aber auch deinen Vater und Mister Crowl vielleicht Redman und Sam. Ich weiß es nicht» [Küster KarlHeinz 1973].

Бу ерда хам ягона абзацдан ташкил топган илова конструкция, бир-биридан маълум узоқликда жойлашган, лекин англатиб келинаётган маъно хусусиятлари жихатидан бир-бирига яқин бўлган иловали элементлар комбинациясидан ташкил топган. Иловали элементлар бир-бирларидан маълум узоқликда жойлашишларидан катьий назар мазмун жихатдан ягона иловали элементлардек ифодаланиб келмоқда. Чунки бундай иловали элементлар ўзларининг қўшимча маъно хусусиятлари билан фақатгина -wen der Ritter Lionheart töten wird каби асосий ифоданинг мазмунини 
конкретлаштириб, тўлдириб, изохлаб қолмасдан, балки иккинчи иловали элемент учун асосий ифода функциясида келувчи -und wenn es dein Vater wahrmacht, daß wir am elften November noch einmal in das Kastell gehen müssen, dann sogar zwei - компонентининг мазмунини хам конкретлаштиради, тўлдиради, изохлайди, реаллаштиради.

\section{Адабиётлар:}

2. Арнольд И.В. Семантика. Стилистика. Интеркультуральность.-СПб.: Изд-во С.Петербург. унта, 1999. -444 c.

3. Реферовская Е.А. Лингвистические исследования структуры текста. Л., 1983. -215 c.

4. Тимошенкова Т.М. Присоединение как особый вид синтаксической связи. Вестник Харьковского гос.ун-та, №159, вып. 1977. -с. 96-100.

5. Туякаева Д.Ш. Структурные особенности присоединительных конструкций современного английского языка. Ж: “Иностранная филология”, Алма-ата, 1975. -с. 51-56.

6. Küster Karl-Heinz. Das Gespenst von Black Rose Gastle. Greifen Verlag zu Rudolstadt,1973. -188 S.

7. Reinowski Werner Zwei Brüder. Mitteldeutscher Verlag Halle (Saale), 1972. -562 S.

\section{ФРАЗЕОЛОГИЧЕСКИЙ ОБОРОТ КАК ЯЗЫКОВАЯ ЕДИНИЦА}

\section{Мусинова Зеботурабовна \\ Старший преподаватель, Самаркандский государственный институт иностранных языков Email:musinova@samdchti.uz}

Annotation: The article considers the objective and strictly linguistic differentiation of phraseological turns, which is the most important task of phraseology as a science, but it is possible only when individual links and departments of the phraseological system are considered as independent special phenomena, but necessarily still as part of the entire phraseology.
Key Words: turnover, phraseology, skills, language, literary, education, series, analysis, system, etc.

Кроме отдельных слов в современном русском литературном языке в качестве особых лингвистических единиц употребляются и более сложные образования, называемые обычно фразеологическими оборотами, или фразеологизмами: нищие духом; завить горе верёвочкой; как пить дать; Мал золотник, да дорог; медвежья услуга; не по дням, а по часам. Поскольку фразеологические обороты выступают в языке в ряду других значимых единиц, раскрытие ихспецифики и характерных признаков требует чёткого отграничения фразеологизмов, с одной стороны, от свободных сочетаний слов, а с другой - от отдельных слов.

Такой «двусторонний» анализ фразеологического оборота как языковой единицы совершенно обязателен: во-первых, фразеологизм функционирует в языке подобно отдельному слову, а во-вторых, по структуре он является сложным целым, компоненты которого осознаются или воспринимаются говорящими в качестве целостных и самостоятельных слов. Только внимательное рассмотрение свойств, отличающих фразеологизм от свободного сочетания слов и сближающих его со словом, а затем свойств, отличающих его от слова, позволяет точно определить понятие «фразеологический оборот» и тем самым то, что должно изучаться в фразеологии как лингвистической дисциплине. Решение этого центрального теоретического вопроса фразеологии имеет определяющее значение не только для построения фразеологической теории русского языка и всестороннего изучения русской фразеологической системы, но и для лексикографической и преподавательской работы.

О том, насколько важно установление того, что представляет собой фразеологический оборот как значимая языковая единица, свидетельствует лексикографическая практика, когда в словарях в качестве фразеологизмов приводятся 
очень часто языковые факты, которые никакого отношения к фразеологии не имеют. Так, в 17-томном «Словаре современного русского литературного языка» рядом с фразеологизмами типа затридевять земель; свободный художник; брать на себя смелость; сердце болит; дама сердца; сесть в калошу; друг ситный; на душе кошки скребут; слава богу; след простыл; взять свои слова обратно; как снег на голову; крыть нечем ${ }^{1}$ указывается обычные словосочетания. В качестве таких «фразеологизмов», толкуемых в словаре без каких-либо оговорок, можно указать, например: на руку «кстати», с кондачка «легкомысленно», в обрез «без излишка», с жиру «от избытка», до смерти «очень сильно», ни-ни «ни в коем случае», еле-еле, не жилец «о том, кто долго не проживёт», на славу «очень хорошо», в свете «с точки зрения», в сердцах «рассердившись», на круг «приблизительно», на словах «устно», рубаха парень, к слову «кстати», не место «не следует».

В «Толковом словаре русского языка» под редакцией Д.Н.Ушакова после знака $\mathbf{m}$, за которым «приводятся и объясняются ходячие цельные выражения», помещаются самые разнообразные языковые единицы: и фразеологические обороты типа выходной день; капля в море; сломя голову; взятки; не в коня корм; надоел хуже горькой редьки, и явные слова (в том числе и такие, которые по традиции пишутся раздельно) типа еле-еле, раным-рано, в пользу, до смерти, в обрез, на совесть. В качестве фразеологизмов (а фразеологизм всегда мыслится как определённое сочетание слов) в словарь включены даже такие языковые образования, как с дребезгом (ср. высока), до упаду (ср. доверху), с панталыку (ср. сначала, где в качестве «отдельного существительного» выступает несуществующее в настоящее время слово (ведь с точки зрения современного языкового сознания слова дребезг, упад, панталык, упад, панталык такие же фикции, как тло в дотла, льзя в обум в наобум).

Таким образом при характеристике фразеологии в целом необходимо учитывать её самые различные проявления. Было бы совершенно неправильным исключать из числа фразеологических оборотов какие-либо образования только на том основании, что они обладают некоторыми особенностями, которые другим не свойственны. Тот факт, что сверхсловность и воспроизводимось как основные свойства фразеологического оборота позволяют отнести к области фразеологии исключительно широкий круг образований, не является основанием для утверждения (как это делают некоторые учёные), что эти признаки не являются конститувтивными. Ведь это отличительные признаки фразеологизмов от смежных языковых единиц (т.е. слов и свободных сочетаний слов). Но никто и не выдаёт их за дифференциальные признаки фразеологических разновидностей.

Литературы:

1. Бабкин А.М. Русская фразеология, её развитие и источники. М. - Л., 1970.

2. Балли Ш. Французская стилистика. М., 1961.

3. Телия В.Н. Что такое фразеология. М., 1966.

\section{ЛЕКСИЧЕСКИЕ РАЗЛИЧИЯ МЕЖДУ КАЛЬКОЙ И МОДЕЛЬЮ}

\section{Мухтарова Шахноза Файзуллаевна Преподаватель, Самаркандский государственный институт иностранных языков Email:muxtarova@samdchti.uz}

Annotation: The article deals with the formation of archaeological terminology, which is a dialect vocabulary that is used to name the realities of old life or reinterpreted in order to nominate special
Key Words: tracing paper, model, be, term, accumulations, dump, heap, 
concepts of archaeology. Regional archaeological terms are formed on the basis of dialect vocabulary.

kitchen, image, language, remains, garbage, etc

Лексические различия между калькой и моделью могут быть обусловлены влиянием дефиниции термина. Так, термин кьеккенмеддинг следовало бы дословно перевести как «кухонная свалка», однако толкование понятия - «раковинные кучи, скопления раковин съедобных моллюсков и других пищевых отбросов на некоторых стоянках эпохи неолита» (1) - и ассоциативная смежность понятий «свалка» и «куча» способствовали появлению термина кухонная куча.

Переосмысления исходной модели может быть весьма значительным, что обусловливает описательность в её передаче (ср.: наскальное изображение <петроглиф<греч. pétros «камень», «скала», glyphé «резьба, вырезывние»).

Структурно-свободное и варьирующее калькирование были широко представлены на ранних этапах формирования археологической терминологии. Неупорядоченностью терминов на этом этапе объясняется широкая вариативность способов перевода терминов, различающихся степенью близости к этимону (ср.: kjokkenmøddingø<kjokken«кухня», mødding «свалка»-кухонные остатки, отбросы, сор; хозяйственные остатки, отбросы, сор; отбросная куча, сорная куча, мусорная куча; куча кухонных остатков, куча кухонного сора; кухонные раковинные скопления, мусорные кучи из раковин), а также наличие большого числа описательных выражений, не являющихся кальками (ср.: раковинные кучи, раковинные скопления, кучи из сора, раковин, костей и каменных орудий). В результате такой конкуренции иногда закреплялся наименее обусловленный этимоном перевод (ср.: петроглиф <греч. pétros «камень», «скала», glyphé «резьба, вырезывние» - резьбы на камне, наскальные вырезки, наскальные рельефы, наскальные изображения).

Причиной калькирования было отсутствие специальных обозначений оправданным. такзаимствуемых понятий, сложность прямого заимствования составного термина, стремление к ясности мотивировки термина. Однако не всегда оно было оправданным. Так, термин, ударная площадка в виде шапочки жандарма, являющийся калькой с французского, «смешное и неуклюжее выражение», по мнению археологов, «ведь мало кому попадается на глаза головной убор французского полицейского» (2). На современном этапе употребление калек необходимо в языке учебной и популярной литературы в целях более доступного толкования термина, дублетом которого является калька. Немаловажную роль играет также необходимость варьировать термин в синтагматической аспекте.

Рассмотренные в работе кальки неравноправны с точки зрения употребления. Некоторые из них (древнекаменный век, новокаменный век, среднекаменный век, меднокаменный век) являются дублетами официально принятых терминов (ㅁлеолит, неолит, мезолит, энеолит) и распространены преимущественно в языке учебно-научной и научно-популярной литературы. Нетерминологический характер имеют эпизодически появляющиеся кальки город мёртвых усая могила. Окказиональной является калька вышгород (ср.: акрополь <греч. akros «верхний», polis «город»)(3), не является общепринятым термин камерная гробнища, предложенный Н.В.Анфимовым во избежание терминологической путаницы для наименования типа погребальных сооружений, которые называются также катакомбами и земляными склепами ${ }^{1}$. В стилистических целях употребляется устаревшая калька древлеведение (ср.: археология). Ряд терминов-калек имеет региональный характер (рытые аллеи), поскольку обозначаемые ими реалии встречаются на определённых территориях. 
Основным генетическим источником археологической терминологии является общеупотребительная лексика русского языка. Сам объект археологии как науки предопределяет необходимость использования различных её пластов, прежде всего обиходно-бытовой лексики, историзмов и архаизмов. Разная степень её терминологизации обусловила наличие ряда переходных групп терминов, связанных, с одной, стороны, с общим, а с другой, со специальным употреблением. Здесь прежде всего следует выделить значительный пласт полифункциональной лексики, соотносимой как с терминологическим, так общеупотребительным значением слов.

\section{Литературы:}

1. Равдоникас В.И. К вопросу о социологической периодизации палеолита т.14. -Л.: 1931.с.61.

2. Филимонов Г.Д. О достоирической культуре в Осетии. - М.: Тип. М.Н.Лаврова, 1878. с.8.

3. Самоквасов Д.Я. Инструкция для научного исследования курганов. - Вильна: Тип. А.Г.Сыргина, 1878.

4. Лотте Д.С. Как работать над терминологией: Основы и методы. - М.: Наука, 1968. С.74.

\section{НЕМИС ТИЛИДА КОММУНИКАТИВ БЎЛАКЛАРГА АЖРАТИЛГАН ВА АЖРАТИЛМАГАН СТРУКТУРАЛИ ИЛОВА КОНСТРУКЦИЯЛАР}

\section{Самарканд давлат Университети ўкитувчи Email:mirzali rahimov.74@mail.ru}

Annotation: In this article, we are talking about connecting structures with communicatively dissected and nondissected structure. The manifestation of such attachments in the text in divided and undivided forms is shown using examples.

Илова конструкциялар қўшимча хабар, фикрнинг белгисини ифодалаш учун хизмат қиладиган ўзига хос синтактик структуралар бўлиб, «аввал билдирилган фикрга қўшимча маъно сифатида яққол намоён бўлади»[1,194]. Илова конструкциялар белгисини кўрсатадиган қўшимча ахборотнинг семантик хусусияти ўзининг формал ифодасини энг аввало, илова алоқаларнинг структурал воситаларида топади: бу махсус бириктирувчи боғловчи ёки унинг семантик аналоглари (ўрнини босадиган сўзлар) «қўшимча ахборот бериш ғояси»ни ифодалайдиган сўз ва иборалардан иборат. Улар одатда алоқида ёки сўз бирикмалари шаклида қўлланиши мумкин.

Қўшимча ахборот (илова) кўрсатгичларига эга бўлган бундай илова конструкциялар матнда бўлакларга ажратилган ва ажратилмаган структураларда намоён бўлиши мумкин.

Er fuhr nach Hause und zog den grauen Anzug an. Hemd und Krawatte [4,17].

Mit niemandem sprach er so offen wie mit ihr, auch über seine privaten Schwierigkeiten und Sergen [6,368].

Таъкидлаш жоизки, илова маъноси фақат махсус кўрсаткичлар - боғловчилар ва уларни ўрнида қўлланиладиган сўзлар ёрдамида ифодаланмайди. Илова ходисасининг асосий ва энг мухим кўрсаткичларидан бири интонация хисобланади: илова конструкциянинг биринчи қисмида тон (оханг)нинг пасайиши ва узоқ пауза(тўхтам), уни А.М.Пешковский «ажратувчи» деб атаган [2,371], улардан кейин ёзувда одатда нуқта, сўроқ ёки ундов белгилари қўйилади. Пауза ажратиб кўрсатилган конструкцияларнинг бир қисми - илова қилинаётган компонент бошланғич, базавий қисм билан синтактик жихатдан боғланиши мумкин. Бундай боғланиш структура жихатдан боғловчили ёки боғловчисиз амалга оширилиши кўзда тутилади:

In den Nebenteilen war es still. Dort waren andere Gedanken. Nach dem Rückzug im Winter 1941 die verloren Schlachten im Sommer und Herbst 1943; und jetzt wieder Rückzug. Über vier Jahre Krieg schon [6, 453]. 
Hast du noch andere Bürger zu benachrichtigen? Ja, den Bürger zu benachrichtigen? Ja, den Bürger Burzot [7: 8).

Шундай қилиб, коммуникатив жихатдан ажратилган ва ажратилмаган илова конструкциялар ўртасидаги фарқ уларнинг илова маъноси структурал ифодаланишга эга бўлиши ёки бўлмаслигида эмас, балки ушбу маънонинг етказиб берилиш усулларининг ўзидадир: ажратилган конструкцияларда формал усуллар, структурал жихатдан коммуникатив ажратилмаган конструкцияларда эса кўп холларда интонацион усуллар намоён бўлади. Демак, илова алоқанинг махсус кўрсатгичларига эга бўлмаган конструкцияларда қўшимча ахборот бериш семантик муносабати унинг қисмларининг контакт жойлашуви ва махсус интонацион расмийлаштириш орқали қўллабқувватланади.

Шундай қилиб, илова конструкцияларга қўшимча ахборот бериш махсус семантик муносабатга эга бўлган алохида синтактик структура сифатида қуйидаги гап структураларини киритиш мумкин:

1) Ушбу муносабатни экспликация қилувчи (шартли белгиларга изох берувчи) махсус кўрсаткичлари уларнинг маъно ва грамматик бутунлигига предикатив қисмларга боғлиқ холда эришишнинг ягона воситаси хисобланади.

2) Ушбу бутунликнинг интонацион расмийлаштирилиши уни илова маъносининг структурал ифодаланиши йўқлигида илова конструкциясига киритиш имкониятини беради.

Қўшимча ахборот бериш семантик муносабати бундай кўринишидаги структурада илованинг махсус кўрсаткичлари орқали ифодаланади, ушбу муносабат маъно нозикликлари, қўшимча маъно бериш хусусиятлари, унинг қисмлари ўртасидаги асосий хукмрон (устун бўлган) семантик-синтактик алоқалар фонидаги нозик хусусиятларда ўз ифодасини топади. Мисол сифатида уюшиқ бўлакларга эга бўлган гапнинг келтириш мумкин, бу ерда илова алоқанинг махсус кўрсатгичлари юқоридаги бўлаклар орқали намоён бўлади:

Jeder sprach sich mit mir aus. Über wichtige Sachen und über jedem Dreck [5,67].

Илова алоқанинг ушбу мисолда кўрсатиб ўтилган кўрсаткичлари келтирилган гапларда уюшиқ бўлаклар ва ажратиб кўрсатилган бўлакларнинг ушбу структуранинг қолган қисмига қўшимча маъно нозикликларини беришга хизмат қилади. Лекин, у гап маъно ва грамматик бутунлигининг ягона воситаси хисобланмайди. Уларни структурадан экспериментал жихатдан олиб ташлаш ушбу гапларни бузилишига олиб келмайди, фақат айтилган фикр мазмунинин маълум даражада ўзгартиради, иккинчи факт(кўшимча бўлак) ажратиб, бундай кўрсатгичларга эга бўлган структураларда улар предикатив қисмларни боғлайди, бундай операцияни бутун конструкциянинг структурал- маъно тузилмасидаги туб ўзгаришларсиз амалга ошириб бўлмайди, бунда улар ўзларининг лексик маъноларини сақлаган холда юқорида келтирилган уюшиқ ва ажратилган бўлакли гаплардагига қараганда кўпроқ грамматик жихатдан шаклланганлиги кўзга ташланади.

\section{Адабиётлар:}

1. Беллерт И. Об одном условии связности текста. В кн.: Новое в зарубежной лингвистике.- М.: Прогресс, 1978, вып 8, с. 172-207.

2. Пешковский А.М. Русский синтаксис в научном освещении. М.: Учпедгиз, 1956. -511 с.

3. Валгина Н.С. Присоединительные конструкции в современном русском языке. М.: Высшаяшкола, 2004.

4. Bredel Willi. Die Söhne. Aufbau -Verlag Berlin und Weimar, 1979. -558 s.

5. Elgers Paul. Jungfrau Johanna. Zweiter Teil Verlag und Epilog. Greifenverlag zu Rudolstadt,1977,425 s.

6. Hofe Günter. Roter Schnee. Verlag der Nation Berlin, 1976, 512 s.

7. Reinowski Werner.Zwei Brüder. Mitteldeutscher Verlag Halle (Saale). 1972, 562 s. 


\section{EL USO DE LOS TROPOS ESTILÍSTICOS \\ DEL MOTIVO DE LA METÁFORA Y DE LA METONIMIA}

\section{Сабирова Гулчехра Абдунабиевна \\ Ўзбекистон Давлат Жахон Тиллари Университети ўқитувчиси}

Annotation: In present work we are going to talk about the metaphor and metonymy. So in metaphor, this substitution is based on some specific analogy between two things, where as in metonymy the substitution is based on some understood association or contiguity. Conclusion in addition to its use in everyday speech, metonymy is a figure of speech in some poetry and in much rhetoric.

Decíamos en el epígrafe anterior que los tropos son estudiados por la retórica como instrumentos destinados al moveré y por la poética como recurso artístico; sin embargo, este hecho no debe llevamos a la conclusión de que existen unos límites estrechos en la aparición de los tropos. Estos artificios lingüísticos trascienden el ámbito del discurso retórico y del literario para instalarse en el lenguaje colloquial e incluso en el científico5: podemos quedar citados con unos amigos para tomar unacopa (metonimia); un ganadero puede comprar 30 cabezas (sinécdoque) más para su rebaño, o bien podemos intentar reparar la pata (metáfora) de la mesa rota. En todas las expresiones antes citadas encontramos figuras lexicalizadas, -el mayor o menor grado de lexicalización hace que para los hablantes pasen casi desapercibidas-, pero estas figuras, y sobre todo la metáfora, son capaces de crear una serie de sistemas conceotuales que a modo de principios o axiomas configuran nuestra visión del mundo e incluso inspiran el desarrollo científico instalándose en la base de nuestras creencias más profundas.

La retórica, el sistema clásico de tropos y figuras estilísticas forma parte obligatoria de la instrucción de una persona.

Hasta el siglo XIX fue la Retórica la ley suprema, la norma para la creación literaria y código de conocimientos. No obstante, las primeras "grietas" teóricas que llevarían después a una completa decadencia de este sistema habían aparecido en el siglo XVIII. Es que el siglo XVIII acabó con la idea absoluta del lenguaje; éste ya no se concebía como algo exterior e independiente del hombre. La tradición linguística de este siglo va partiendo del principio que el idioma de las obras literarias refleja la experiencia individual humana y proclama la tesis "el estilo es el hombre" (Buffon). Las exigencias rigurosas de la retórica de seguir siempre las reglas y normas establecidas, se sustituyen por el concepto de la libertad del proceso creativo. Como consecuencia de este enfoque teórico, se da inicio en la literatura a una nueva corriente llamada el romanticismo, que no depende ya de la retórica y sus conceptos.Pero en el transcurso del tiempo, esta estilística "individual" tampoco resultó ser perfecta en sus postulados teóricos ya que la declaración sobre la individualidad y originalidad del estilo de cada escritor imposibilitó su investigación y clasificación científicas (por ser infinita la cantidad de estilos). Estas son las causas primordiales de no poder formarse la estilística como ciencia en los siglos pasados, y la retórica sigue enseñándose más bien por tradición, como parte de la gramática del idioma. Para el desarrollo posterior de la estilística resultaron muy fecundas las ideas del ilustre linguista ginebrino Ferdinand de Saussure (1857-1913), que planteó una orientación nueva en el estudio del idioma poniendo de relieve la necesidad de destacar dos realidades de un mismo fenómeno, la lengua y el habla.El deslinde de Saussure dio una extraordinaria claridad sobre el estudio estilístico del lenguaje, y a base de su concepción de la lengua se formaron dos escuelas linguísticas que difieren sólo en cuanto a los métodos de análisis: la escuela idealista (p. 10-11) y la escuela franco-suiza. Respectivamente nacen dos estilíslicas: estilística del individuo (escuela idealista) y estilística de la expresión (escuela 
franco-suiza). Posteriormente la primera se convirtió en la crítica literaria y la segunda sigue manteniendo íntima relación con la linguística.El fundador de la estilística de la expresión y también de la actual, es considerado que es Charles Bally (1865-1947), discípulo de Saussure y su sucesor en la cátedra de la Universidad de Ginebra. Charles Bally es autor del primer y básico tratado de la estilística, "Tratado de la estilística francesa" (1909). Fue el primero en declarar que la estilística, como ciencia linguística, no ha de limitarse al estudio de los estilos individuales de poetas y escritores, sino debe dedicarse al estilo de la comunidad. De todos los poderes con que cuenta el hombre para su desarrollo tal vez ninguno es más amplio y vigoroso que el lenguaje. Debido a eso, la humanidad aspiró siempre a poseer conocimientos profundos y multilaterales de la lengua, siendo ésta un instrumento importante en las relaciones humanas".

Los problemas de elegir una palabra adecuada, de manejar eí idioma preocupaban a la gente desde tiempos remotos.Hace nías de dos mil años fue precisamente la Retórica griega la que determinaba las reglas de la actividad literaria. Esta Retórica había sido heredada por nosotros en la variante romana.La Retórica es una ciencia ligada con el arte de componer discursos, oratorias y atendía, en primer lugar, las necesidades de juristas y, luego, las de estadistas, etc.Posteriormente estas normas se extendieron a todn la poética. La retórica antigua perseguía un solo objetivo: el de enseñar a emplear el idioma de modo que fuese un instrumento flexible para convencer y persuadir a los oyentes apelando a sentimientos, pasiones y raciocinio a la vez.Para llevar este fin a la práctica fueron elaboradas por esta disciplina reglas rígidas que servían de norma para cada orador y escritor. Por ejemplo, la elección de la forma de expresarse dependía del carácter, el tema, la idea y las condiciones en que sería realizado este discurso. Cada forma correspondía a un género determinado, y a éste, un estilo propio. Cada estilo fue rigurosamente definido en el vocabulario, la sintaxis y las figuras.Los antiguos distinguían tres estilos: humilis stylus (el simple), mediocrus stylus (el temporado) y gravis slylus (el sublime). Al último, por ejemplo, correspondía un personaje guerrero, de nombre Héctor o Ajax; como animal, un caballo; como arma, la espada; como residencia, la ciudad o el campamento; como plantas, el laurel y el cedroSe puede deducir, que la retórica de los antiguos poseía un carácter normativo o prescriptivo, procurando unificar los criterios de aplicación del idioma.

Este enfoque fue natural para aquel entonces, pues los antiguos, siendo metafísicos en su filosofía, consideraban al hombre y e! universo creados por origen espiritual. Según ellos, el mundo es originado por ideas, y el idioma y la literatura han de expresar estas ideas. Precisamente este punto débil de su concepción filosófica es causa de cierta deficiencia linguística.Sin embargo, cada linguista contemporáneo que se dedica a la estilística debe conocer con perfección la retórica. La herencia de esta disciplina sigue vigente hasta nuestros días: son la teoría de los tropos y figuras de dicción, la versificación (métrica) y muchas oirás esferas. Son, sin duda, estos méritos los que hacen justa y veraz la evaluación de la Retórica ofrecida por el estilista francés P. Giraud: "Ella es ciertamente de todas las disciplinas antiguas la que mejor merece el nombre de ciencia. La amplitud de las observaciones, el rigor, la finura del análisis, las precisiones de las definiciones, eí rigor de las clasificaciones constituyen un estudio sistemático de los recursos del lenguaje que no tiene equivalente en los otros conocimientos humanos de aquellos tiempos".Los más importantes tratados de Retórica clásica son: "Poética de Aristóteles"; "De Oratore y Orador" de Cicerón; "De instilutione oratoria" de Quintiliano.La Edad Media es época de cierto estancamiento en el desarrollo de teorías estilísticas, aunque la retórica medieval logró elaborar unos géneros nuevos: vidas de santos, canciones de gesta, drama litúrgico, etc. Esto se explica, sobre todo, por no estar todavía establecida la norma idiomática del español.En el siglo XVI vuelven a revivir las normas clásicas, porque en este siglo se observan grandes transformaciones tanto en la vida social de España como en la literatura. Es el período de esplendor del Renacimiento español, con su interés especial por las obras 
maestras clásicas. Van apareciendo gran catitidad de instrucciones retóricas lo que testimonia un creciente interés respecto a los problemas del estilo idiomático.

\section{Адабиётлар:}

1. ZAMORA, Juan y Jorge GUITART. 2012. "Geografía lingüística”, Dialectología hispanoamericana. Teoría - Descripción - Historia, Salamanca, Eds. Almar.

2. Real Academia Española (2014): Diccionario de la Lengua Española. Madrid: Espasa-Calpe. Vigésima edición.

3. MALDONADO, C. [dir.],): Clave. Diccionario de uso del español actual (2009), 3.a ed., Madrid, SM, 2009.3 (Citamos Clavé).

4. LÓPEZ MORALES, Humberto. 2019. Sociolingüística, Madrid, Gredos.

5. Boletín informativo, Madrid, Fundación Juan March, 2012, 4.

\section{ИНГЛИЗ ВА ЎЗБЕК ЛИНГВОМАДАНИЯТЛАРИДА ГАСТРОНОМИК ФРАЗЕОЛОГИЗМЛАРНИНГ ТАЛҚИНИ}

\section{Саидакбарова Саодат Пархаджановна Тошкент Давлат Шарқшунослик Университети мустақил тадқиқотчи Email:saodat.83@list.ru}

Annotation: The paper discusses the importance of gastronomic idioms and the way in which they reflect the ethnic and cultural identity of a given nation. Gastronomic idioms can be analyzed in three different perspectives, i.e. the international, national and the local. The article proves the idea that gastronomic idioms are best option to learn about nation and its traditions. Gastronomic idioms are signs of any nation and can illustrate history and culture of nation. English and Uzbek idioms were excerpted from a variety of lexicographic works and analyzed in a cultural perspective.

Гастрономик фразеологизмларнинг шахс ёки нарса-предмет тавсифида қўлланилиши махсулотнинг ташқи кўриниши, ранги, хусусияти, тайёрланиши ва таъмига асосланади. Кишилардаги жамики ижобий хусусиятлар ва салбий иллатлар ифодаси гастрономик фразеологизмлар яратган образли тасвир асосини ташкил қилади. Гастрономик фразеологизмлар асосида берилган тавсифлар кишини ўз хаттихаракатини холис бахолашга, тўғри хулоса чиқариб, кейинги фаолияти хусусида фикр юритишга ундайди. Муайян халқ маданий хаётини ёритиб, миллатлараро ўхшаш ва фарқли дунёқараш ифодасида мухим ахамият касб этади.

Гастрономик фразеологизмларда маъно тараққиёти икки усул кўчириш ва тадбиқ усули билан амалга ошади. Кўчириш усуларидан метафора асосий ўрини эгаллайди. Масалан, кўнгил кўтармайди ибораси биринчи маъносида (еб ича олмаслик) нарсаларга нисбатан ишлатилса, иккинчи маъно (ёқтирмаслик) бу иборани овқатдан бошқа нарсаларга кўчириш асосида шаклланганини кўриш мумкин. (Рахматуллаев, Ўзбек тилининг фразеологик луғати, 1992). Ш. Рахматуллаев ибора бир предметдан бошқасига кўчирилмайди, улар янги маъно мавжуд маънога хос семантик чизиқни давом эттириш орқали юзага келади дейди. (Рахматуллаев, 1992). Фразеологик маъноларнинг бирбиридан ўсиб чиқмаганлигини, жумладан, сутдек оқ ибораси биринчи маъносида кимнингдир ташқи кўринишига (баданига) нисбатан ишатилса, иккинчи маъно (характерга) инсоннинг покдомон, покдил мутлоқ бегунохлигига нисбатан ифодаланади. Шундай қилиб, бир ибора гапнинг контекстига қараб инсоннинг кўриниш ёки унинг характерига нисбатан кўчирилади, биринчи маъносидан кўчириш асосида юзага келган.

Гастрономик фразеологизмларнинг яна бир хусусияти шундаки, уларнинг маъно ва услубий вазифа жихатларидан ўхшаш эквивалентлардан гохо бир тилдагисининг образлиликни юзага келтирадиган таянч компонент иккинчисидагидан бир компонентга кам бўлиб, фикрни нутқ маданияти доирасида ифода этиш масъулияти бу 
ерда хам хар қайси тил меъёрига риоя қилиш заруратини туғдиради. Масалан, ўзбеклар хеч қачон «Нон хақи» ўрнига инглизлар сингари «Нон ва туз хақи» (By bread and salt) деб қасам ичмаганларидек, инглизлар хам «Бировнинг нонини емоқ ва тузини ичмоқ» (То eat somebody's bread and salt) ўрнига ўзбеклардек «Бировнинг тузини ичмоқ» демайдилар. (Усманова, 2017). «Яхши қуролланмоқ» хамда «Бировнинг асабига тегмоқ» тушунчаларининг образли ифодаси учун ишлатиладиган фразеологизмларнинг инглиз ва русча вариантлари таркибларидаги компонентлар миқдори хам уларнинг узбекча эквивалентларидагидан биттадан компонентга кам бўлиб, таржима тили бирликлари лексик таркибларининг қабул қилинган анъанавий тарзда қўлланилишигина ифоданинг тил меъёри доирасида талқин этилишига олиб келган.

Тахлил натижаси шуни кўрсатдики, инглиз ва ўзбек миллатлари бир- биридан фарқ қилишига қарамай, айрим мева ва сабзавот номи ишлатилган ибораларнинг маъноси бир-бирига жуда яқин. Уларнинг аксарияти иккала тилда хам инсоннинг фазилатларини, хислат ва хусусиятларини тасвирлайди. Масалан, ўзбек тилида бирон бир ақлий томондан етук бўлмаган, жуда хам содда, бир қадар гўл инсонларга нисбатан думбул тентак ибораси ишлатилади. (Шотурсун Шомақсудов, Субутой Долимов, 2018). Бугунги кунда ёшлар нутқида хам айни маънода “бодринг” сленгини кузатиш мумкин.

Яна шундай иборалардан бири bad apple иборасидир. Унга ўзбек тилидаги ўйин бузиқи ибораси муқобил бўлади:

The bad apple is not a team player and they make it their mission to cause problems within a unit (E. Long, "The Bad Apple").

ўйин бузиқилар хеч қачон жамоа ўйинчиси бўлолмайдилар, аксинча, улар муаммо чиқазишни ўзларига мақссад қилиб оладилар.

Таркибида мева компоненти иштирок этган ибораларни диний матнларда хам жуда кўп учратиш мумкин. Жумладан, forbidden fruit иборасини сўзма-сўз таржима қилинганда, у тақиқланган олмани билдиради. “Инжил” китобидан, Худо томонидан танаввул қилиш тақиқлаб қўйилган эзгулик ва ёвузлик дарахти меваси афсонасидан келиб чиққан:

"Илон хотинга:

- Чиндан хам Худо, боғдаги хеч бир дарахтнинг мевасидан еманглар, деб айтдимикин? - деди. Хотин илонга деди:

- Боғ дарахтларининг мевасидан ея оламиз-у, Худо фақат боғнинг ўртасидаги дарахмтнинг мевасини еманглар, унга тегманглар, бўлмаса ўласизлар, деди" (Инжил, 619).

Таркибида “apple " компоненти иштирок этган яна бир гастрономик фразеологизмлардан бири an apple of one's eyes дир. Бу ибора ўзбек тилида кўз қорачиғи, яъни жуда хам яқин ва қадрдон инсон (кўпинча фарзанд) хақида сўз борганда ишлатилади. Инглиз тилида бу ибора 1611 йили Қирол Жамез Версионнинг таржималаридан кириб келган деган тахмин бор. Бинобарин, мазкур иборани У. Шекспирнинг “A Midsummer Night's Dream” (“Ёз тунидаги туш”) асарида хам учратиш мумкин:

Flower of this purple dye,

Hit with Cupid's archery,

Sink in apple of his eye"

Бинафша ранг бўёқнинг гули,

Купидон камонига санчилди,

Ва ўз кўз қорачиғига ғарқ бўлди.

Буюк ёзувчи ва адиб У. Шекспир инглиз фразеологик фондига жуда катта хисса қўшган. Унинг асарлари турли хил фразеологик бирликларнинг шаклланишига асос бўлган. Ёзувчи ўз асарларида халқ иборалардан унумли фойдаланиш билан бирга, ўзи хам янги, “теша тегмаган” иборалар яратган. 
Гастрономик фразеологизмлар ўзининг миллийлиги хамда ўзига хослиги билан ажралиб туради. Гастрономик фразеологизмларнинг тахлили тегишли дунё тиллари ва уларда сўзлашувчиларнинг дунёқарашини, фикрлаш доирасини тушуниш ва ўрганиш учун қимматли маълумотлар манбаи бўлиб хизмат қилади.

\section{ISPAN TILIDA OMONIMLAR VA ULARNING LEKSIK-SEMANTIK XUSUSIYATLARI}

\section{Tursunova Mavluda Erkinovna TIQXMMI Buxoro filiali o'qituvchisi}

Omonimlar - umumiy ma'no unsurlariga ega bo'lmagan, tasavvuriy bog'lanmagan, lekin bir xil yozilib, bir xil aytiladigan so'zlar; ular orasida semantik aloqa bo'lmaydi. Ana shunday so'zlarning tilda mavjud bo'lishi va shunga bog'liq hodisalar omonimiya deyiladi. Omonimning lug'aviy va grammatik ko'rinishlari farqlanadi.[5,56]

Omonimlarning tilda paydo bo'lish sabablari turlichadir: avvallari har xil aytilib, bir xil eshitiladigan so'zlar talaffuzining tarixiy jarayonda tovush almashinishi yoki talaffuz o'zgarishi natijasida bir-biriga mos kelib qolishi; (ot - ism, ot - hayvon; o't - olov, o't - o'simlik) boshqa tillardan o'zlashgan so'zlarning talaffuz va yozilish jihatidan ona tilidagi so'zlarga mos kelib qolishi (turbosqich; tur-xil, nav); tilda mavjud bo'lgan ko'p ma'noli so'z ma'nolarining birbiridan uzoqlashishi (dam — nafas; dam — hordiq; dam — bosqon) va b.

Omonimlar bilan bir qatorda tilda ularning alohida turlari sifatida omograflar (bir xil yoziladigan, lekin urg'u va talaffuz bilan farqlanadigan so'zlar: olma-olma, tom (uy tomi) tom (kitob tomi) va b. hamda omofonlar (bir xil talaffuz qilinadigan, lekin yozilishida farq qiladigan so'zlar: yetti (son) - yetdi (fe'l); yot (begona) - yod (xotira) va b. Omonimiyaning mazkur barcha ko'rinishlariga mansub so'zlar ma'nosi asosan matn orqali bilinadi.

Ispan tilida omonimlarga misol qilib quyidagilarni keltirish mumkin bo ladi bunda rus tilida kelgan so`zlar bilan omonimlik hodisasini uchratish mumkin.

\begin{tabular}{|c|c|}
\hline $\begin{array}{l}\text { arena (qum) - арена (o’ralgan yumaloq } \\
\text { o'yingoh) } \\
\text { banda (belbog; guruh) - банда (jinoiy guruh) } \\
\text { cara (yuz) - кара } \\
\text { carta (xat) - карта } \\
\text { dar (bermoq) -подарок } \\
\text { dudar (ikkilanmoq) - дудка } \\
\text { gallina (tovиq) -Галина } \\
\text { озо (aуiq) -аса }\end{array}$ & $\begin{array}{l}\text { pan (non) - пан } \\
\text { parada (bekat) -парад } \\
\text { pica (o'tkir) -пика } \\
\text { plata (kumush) -плата } \\
\text { plato (tarelka) - plato } \\
\text { rana (qurbaqa) - paна } \\
\text { son ("ular bo 'lishdi" - "ser"- "bo'Imoq" fe'li } \\
\text { pastel (pirog) - nacmeль } \\
\text { para (uchun) -пара } \\
\text { уа (allaqachon) -я }\end{array}$ \\
\hline
\end{tabular}

barcha bu so`zlar ko`pincha rus tilidagi so`zlar bilan omonimlik vazifasini bajaradi.

Ushbu misollarda ispan tilini o`rganish osonroq bo`ladi.Omonimlar talaffuz qilinishi bir ammo ma`nolari har xil bo`lgan so`zlar hisoblanadi.Ispan tilida ikki xil omonimlarni ajratish mumkin bo`ladi.

Omonimlarning leksik semantik xususiyatlarini oladigan bo'lsak unda omonimlarni quyidagi guruhlarga ajratish mumkin bo ladi:

- $\quad$ qisman bo'lgan omonimlar- ushbu omonimlarning talaffuz jihatdan doimo ham mos tushmaydi.

- $\quad$ Grafik omonimlar- bu omonimlar omograflarga to`g`ri keladi

- $\quad$ Fonetik omonimlar -bu omonimlar omofonlarga to`gri keladi

- Omonimli morfemalar- bular omonimli morfemalarga tegishli bo ladi.

- Grammatik omonimlar.Bu omonimlarning turi omoformalarga tegishli bo ladi.

- Vino - Del verbo venir.Venir fe lidan kelgan. Vino - Bebida alcohólica alkogol ichimligi. 
Copa -Parte del sombrero- shlyapaning bir qismi, Vaso con pie para tomar -ichish uchun qadah, Parte más alta del árbol -daraxtning uchki qismi, Del verbo copar - copar fe lining tuslangan shakli.

Casa- de hogar - uy -joy, del verbo casar- casar fe`lining tuslangan shakli.

Zamon rivojlanishi bilan tilda ham o`zgarishlar sodir bo`ladi. Har bir tilning o`ziga xos xususiyatlari, bajaradigan funksiyasi mavjud. Har bir til o'zining boyligiga, rivojlanish tarixiga ega.Bunday holatlardan ispan tili va o`zbek tili mustasno emas. Har bir tilda o`ziga xos funksiyani bajaruvchi so`z mavjud. Har bir til o`zining so`z boyligiga ega. Uning bir ma`noligi, ko`p ma`noligi yoki sinonimlari, antonimlari va omonimlik holatlari mavjud bo ladi bunda tilning xilma xilligini naqadar boy ekanligini ko`rish mumkin bo`ladi. Har bir so`z gapda, muloqot jarayonida ma'lum bir vazifani bajaradi. Omonimlik hodisasi boy hodisa bo'lib, uning semantik-grammatik leksik xususiyatlari ham mavjud.

\section{Adabiyotlar :}

1. Karimov I.A.Yuksak ma`naviyat yengilmas kuch.-T. 2008.- 61 b.

2. Борисенко М. Грамматика испанского языка. М. 1997.-45 c.

4. Васильева - Шведе О.К., Степанов Г.В. Грамматика испанского языка. Москва, 1983.- 658 с.

5. Васильева - Шведе О.К., Степанов Г.В. Теоретическая грамматика испанского языка. Москва, 1980.- 680 с.

6. Виноградов В.С. История испанского языка. Москва: Высшая школа, 1985.-457 с.

7. Виноградов В.С. Грамматика испанского языка. Москва, 2010.- 432 с.

8. Деев М.Н. Предлоги современного испанского языка. Москва, 1993.-346 с.

9. Данилевская Р., Патрушев Е.И., Степанина И.Л. Учебник испанского языка. I-II-часть М. 2000.$356 \mathrm{c}$

10. Карпов Н.П. Фонетика испанского языка. Москва, 1979.- 287 с.

\section{FRANSUZCHA BIR BO'G'INLI SO'ZLARNI AVTOMATIK TARJIMA QILISHGA XOS MA'NO TURLARI}

\section{Shukurova Ra'no Akmalovna Jabborova Xabiba Quvondiqovna Samarqand davlat chet tillar instituti o'qituvchilari Email:shukurova@samdchti.uz Email:jabborova@samdchti.uz}

Annotation: Ushbu maqolada bir bo'g'inli so'zlarning semantik xususiyatlari fransuz tili materialida tahlil qilingan. Bunday tahlildan ko'zlangan maqsad bir bo'g'inli so'zlarni kompyuter tarjimalarida ularning ma'no ottenkalarini inobatga olishdan iborat. polisemiya masalalari ham o'rganiladi. Tildagi so'zlarning juda katta qismi ko'p ma'nolidir, chunki kishilar o'zining kundalik hayotida yangi paydo bo'lgan tushunchalarning har biri uchun alohida-alohida so'zlar qo'llayveradigan bo'lsa, so'zlarning soni o'ta ko'payib ketib, ularni xotirada saqlash mumkin bo'lmay qolardi. Natijada tildan foydalanish ham qiyinlashib, u sekinasta yaroqsiz holga kelib qolgan bo'lardi[2].

Til bilan fikr orasida o'zaro jipslik, uzviy aloqa bo'lgani kabi inson tafakkuri til, so'z, tushuncha o'rtasida ham uzviy bog'lanish mavjud.har qanday so'z avvalo, etimologik, dastlabki ma'noga egadir. Shu etimologik, dastlabki ma'no ayni paytda so'zning (bosh) asosiy ma'nosi hamdir. Lotin tilidan o'tgan aksariyat so'zlar hozir ham asosiy ma'nosiga ega. Biroq asrlar davomida so'zlarning asosiy ma'nolari unutilib, yasama (ko'chma) ma'nolarga ega bo'lishi ham mumkin. Masalan: "partir" fe'li, avval "bo'lmoq", keyinchalik esa "jo'nab ketmoq" ma'nosini, "travailler"fe'li avval "qiynamoq, azob bermoq", hozir esa "ishlamoq", "tête" so'zi avval "ko'za", 
hozir esa "bosh" ma'nolarini ifoda etadi. "Cadeau” so'zi provansal tilidan olingan bo'lib, avval qo'lyozmadagi bosh harfni bildirgan, keyinchalik xotinlarga taqdim etiladigan har qanday bezakni ifodalagan, hozirgi kunda esa har qanday sovg'ani ifodalayveradi. Shunday qilib hozirgi paytda tête, cadeau, travailler, partir va hokazo so'zlarning yasama ma'nosi asosiy ma'nosiga aylangan.

Fransuz tilining kundalik iste'molda foydalanadigan leksikasining aksariyati ko'p ma'nolidir. Ko'p ma'nolik-polisemiya ayrim so'zning ma'lum davrda bir qancha ma'nolarga ega bo'la olishidir. Umumiy hislatga ega bo'lgan bir qancha dalillarni, bir qancha narsalarni ko'rsata oladigan so'z ayni paytda bir qancha ma'noga ham ega bo'la oladi.

Fransuz tilida ko'p ma'nolilik asosan, fe'llarga va ot so'z turkumlariga xos xususiyatdir, bu faktni, sintetik tuzumdagi tillar bilan taqqoslaganda, ya'ni hozirgi fransuz tilida, flektiv tillar tuzilishidagi kabi yasovchi elementlarning kamchiligi bilan isbot qilishi mumkin.

Shuning uchun ham fransuz tilidagi bir qancha perifrazalarni beradigan fe'llar o'zbek tilida bir fe'l bilan berilishi mumkin. Masalan: prendre froid-shamollamoq, faire peur à qnqo'rqitmoq.Fransuz tilidagi bir lug'atlarda mettre-qo'ymoq va prendre-olmoq fe'llarining 80 dan va main-qo'l va tête-bosh otlarining 60 dan ortiq ma'nolari keltiriladi va hokazo.

Demak, ko'p ma'nolikda fe'llar birinchi o'rinni, otlar esa ikkinchi o'rinni egallaydi.

Bir necha ma'noga ega bo'lgan har qanday so'z kontekstda aniq bir yagona ma'noga ega bo'ladi. Bunga monosemiya-bir ma'nolik deyiladi ${ }^{1}$.

Ko'p ma'nolilik va bir ma'nolilik taraqqiyot birligidir. Ongimizdagi so'zning ma'nosi nutqda, kontekstda oydinlashadi. Qo'shni so'zlarning ma'nolari so'zning asl ma'nosini keltirib chiqaradi. Masalan: ce village a 200 feux-gapida qo'shni so'zlarning ma'nolari "feu" so'zining asl ma'nosi ekanligi, ya'ni o'zining eskirgan ma'nosida ("foyer"-xonadon) maison (uy) so'ziga sinonim ekanligi anglab olinadi va bu qishloqda 200 ta (olov) bor deb emas, balki bu qishloqda 200 ta xonadon bor deb tarjima qilinadi.

Bir bo'g'inli so'zlarning ikki ma'noli so'zlarini tarjima jihatdan tahlil qilganimizda tarjimasi boshqa-boshqa bo'lgan so'zlar ancha keng tarqalganini ko'rishimiz mumkin. Tahlil jarayonida ikki ma'noli so'zlar ichida ayrim so'zlarning ikkinchi ma'nosi tarjima qilinmaydi. Masalan: Il kishilik olmoshi birinchi ma'nosi $u$ deb tarjima qilinsa, ikkinchi ma'nosi tarjima qilinmaydi, bunda il shaxssiz forma sifatida qo'llaniladi. Masalan :

1) il va au college - u kollejga borayapti.

2) il neige - qor yog'ayapti.

-ou bog'lovchisining birinchi ma'nosi yoki deb tarjima qilinsa, ikkinchi ma'nosi tarjima qilinmaydi. Masalan :

1) maintenant ou jamais - hozir yoki hech qachon.

2) les groupes de cinq ou six hommes - besh (yoki) olti kishili guruh

-la pompe so'zining ham ikkita tarjimasi bo'lib, birinchisida nasos deb tarjima qilinsa, ikkinchi ma'nosida esa ibora sifatida qo'llanilayapti, ya'ni la pompe funèbres - dafn qilish byurosi.

Ayrim so'zlar birinchi ma'nosida boshqa so'z turkumi bo'lsa, ikkinchi ma'nosida boshqa so'z turkumi bo'lib kelyapti. Bularning tarjimasi bir-biriga yaqin yoki tarjimasi boshqa-boshqa bo'lib kelyapti. Masalan:

$$
\begin{aligned}
& \text { Est-1) sharqiy (sifat) 2)m sharq (ot) } \\
& \text { Être - 1) bo'lmoq (fe'l) 2) m maxluq (ot) }
\end{aligned}
$$

Des artikli tarjima qilinmaydi va u ikki usulda qo'llanishini ko'rishimiz mumkin. Birinchisida noaniq artiklning ko'plik shakli bo'lsa, ikkinchisida tutash artiklning ko' plik shakli sifatida qo'llaniladi.

Tahlil qilganimizda bir bo'g'inli so'zlarning ichida alternatsiyaning fonetik turi jihatdan [w], [j] yarim undosh yoki yarim unlilari [4] yarim undosh yoki yarim unlisiga nisbatan ko'proq tarqalganini va alternatsiyaning tarixiy turi jihatdan esa so'z oxiridagi undoshning o'qilishi va 
o'qilmasligi yo'nalishi qolgan ikki yo'nalishiga nisbatan keng tarqalganini ko'rishimiz mumkin. Va shuni ham aytish kerakki, bir bo'g'inli so'zlar ichida alternatsiyaning fonetik turi tarixiy turiga nisbatan ancha keng tarqalganini ko'rishimiz mumkin.

Bir tildagi so'zlarning har xil formalarida ham tovushlar almashuviga alternatsiya deb ham yuritiladi. Uning almashinuvi ikki xil bo'ladi: fonetik (pozitsion) va tarixiy. Bir bog'inli so'zlar ichida alternatsiyaning ikkala turi ham mavjud bo'lib, fonetik alternatsiya keng tarqalgan. Ma'lumki, fransuz tilida ko'p ma'noli so'zlar ancha keng tarqalgan. Xususan, bir bo'g'inli so'zlarni bir, ikki, uch, to'rt, besh va ko'p ma'noli so'zlar yuzasidan tahlil qilganimizda bir ma'noli so'zlar ko'pchilikni tashkil etdi, keyingi o'rinda ikki ma'noli so'zlar tashkil etdi. Bir bo'g'inli so'zlarning ikki ma'noli so'zlarini tarjima jihatdan tahlil qilganimizda tarjimasi boshqaboshqa bo'lgan so'zlar ancha keng tarqalganini ko'rishimiz mumkin. Tahlil jarayonida ikki ma'noli so'zlar ichida ayrim so'zlarning ikkinchi ma'nosi tarjima qilinmaydi. Bir bo'g'inli so'zlar birinchi ma'nosida boshqa so'z turkumi bo'lsa, ikkinchi ma'nosida boshqa so'z turkumi bo'lib, ularning tarjimasi bir-biriga yaqin yoki boshqa-boshqa bo'lishi mumkin.

\section{Adabiyotlar :}

1. Сафаров Ш. Семантика.- Тошкент, 2013. -316 б.

2. Arrivé M., Gadet F., Galmiche M. La grammaire d'aujourd'hui: guide alphabétique de linguistique française.-Paris, 1986.- 534p.

3. http://www.expressio.fr/expressions

4. http://www.francparler.com

\section{ХОРИЖИЙ ТИЛШУНОСЛИКДА НОРМА ТАЛҚИНИ}

\section{Ходжаева Гулшод Бахадировна Урганч Давлат Университети ўқитувчиси Email: asalcha-80@mail.ru}

Annotation: This article discusses the Key Words: language, norm, normative, interpretation of norms in foreign linguistics. $\quad$ speech culture, literary language, linguistics.

Маълумки, давлат тили хақидаги қонун жорий қилингандан кейинги даврда ўзбек тилидаги ўзлашган сўз ва терминларни, айниқса байналминал терминларни қайта кўриб чиқишга бўлган интилиш кучайди.

Тил, асосан, ўз ички имкониятлари асосида ривожланади. Шу билан бирга, ўзаро иқтисодий, маданий алоқалар туфайли четдан сўз олиш ва ўзлаштириш дунёдаги барча тилларга хос хусусиятдир. Бу жараён ўзбек тилига хам тааллуқлидир.

Тилшунослик фани ўз шаклланиш ва ривожланиш тарихига эга бўлгани каби тил нормаси муаммоларини ўрганиш хам маълум тарихга эга. Тил нормасига оид муаммолар пайдо бўлгандан буён чет элларда, собиқ Иттифоқда ва мамлакатимизда бу масалага бағишланган бир қатор назарий ва амалий ишлар қилинди. Аммо тил нормасининг мохияти ва унинг тил тизимидаги ўрни ханузгача етарли даражада деб бўлмайди.

Лисоний норма назарияси бўйича фикр юритган тилшунослар Э. Бегматов ва А. Маматовлар ўз тадқиқотларида норма муаммоларини ўрганиш борасида тўрт асосий марказ мавжудлигини қайд қилдилар.

Булар : 1) чех ( Прага ) тилшунослик мактаби ; 2) Э. Косериунинг илмий назариялари ; 3) америка, инглиз ва немис тилшуносларининг илмий қарашлари ва 4) собиқ Иттифоқ тилшунослигидаги илмий назарий қарашлар. Прага тилшунослик мактаби намояндалари тил нормасини, адабий тилнинг асосий 
вазифаларини адабий тил нормаси кодификациясининг амалий масалалари билан бирга узвий холда тахлил қилдилар.

Улар тил нормасини у ёки бу тилда сўзловчи умумжамоа томонида мунтазам равишда фойдаланиладиган лисоний структура воситаларининг йиғиндиси деб тушундилар. Тил нормасини илмий - назарий жихатдан тахлил қилишда бу мактаб аъзоларидан Б. Гавранек, В. Матезиус, А. Едличка, В. Барнет, Е. Вахек ва бошқаларнинг хизматлари диққатга моликдир.

Жумладан, Б. Гавранек ўз илмий кузатишларида нормани тизим ( система) сифатида характерлаб, норма тушунчаси тил мавжудлиги доирасига бевосита алоқадорлигини ва тил доирасида мажбурий кўлланиллишини таъкидлайди.

У адабий тил мохиятидан келиб чиқиб, унинг янги тушунчаларини тавсия қилди хамда тил нормаси ва адабий тил кодификацияси назариясини асослашга уринди, адабий тилнинг услубий ( стилистик), қабатланганлик назариясини вазифавий ( функционал ) нуқтаи назардан ёндашган холда ишлаб чиқди ва чех нутқи маданиятининг ривожланишига катта хисса қўшди.

Бу масалада В. Барнет хам фикр юритиб, адабий тил нормаси билан ноадабий тил нормалари орасидаги фарқлар тил системаси ва норма, кодификация ва узус орасидаги муносабатлар билан боғлиқдир. Тилнинг ноадабий кўринишларида норма система ва узуснинг муносабатидангина иборат бўлади, - деган хулосага келади.

Яна бир чех олими Йозеф Вахек4 тил ёзув шаклининг ижтимоий ахамияти тўғрисида кузатишлар олиб бориб, ёзув тилини лисоний нуқтаи назардан ўрганиш зарурлигини таъкидлайди ва тил ёзув шаклининг ижтимоий ролини, унинг ижтимоий обрўсини юксак бахолайди, деган хулосага келади.

Шундай қилиб, Прага лингвистик тўгараги аъзолари адабий тил ва унинг нормасининг функционал мохияти хақида яхлит, бир бутун ғоя яратдилар. Кейинчалик эса норма муаммоларини тадқиқ қилиш тил воситаларининг қўлланилишини муайян тартибга, нормага солиш асосида олиб борилди. Норма тушунчасига бу каби янгича ёндашиш машхур тилшунос Э.Косериу таълимоти билан бевосита боғлиқ. Э. Косериу нормани ижтимоий нуқтаи назардан объектив, тартибга солинган ва танланган ходиса деб тушунса, кодификацияни - субъектив, фақат тил нуқтаи назардан тўғри бўлган ходиса, категориядир деб тушунади. Унинг фикрича, тил системаси ва структураси тилнинг хамма ходисаларини ўз ичига қамраб ололмайди. Хар бир тил ўз ифода томонидан хам, маъно томонидан хам ўзининг вариантдорлик хусусиятларига эга.

Э.Косериунинг диққатга сазовор бўлган хизматларидан яна бири шуки, у тил нормаси ва кодификацияси ўртасидаги чегарани аниқлаб берди. Олим ўз илмий ишларида тил нормаси ва унинг кодификацияси ходисаларини чегаралаш юзасидан Прага лингвистик тўгараги намояндалари олдинга сурган ғояларини янада тўлдирди ва мукаммаллаштирди. Лекин чех тилшуносларининг ғоялари билан Э. Косериу фикрлари ўртасида маълум фарқлар мавжуд.

Инглиз тилшунослигида тил нормасининг мохиятини аниқлашда бир неча йўналишлар мавжуд. Биринчи гурухга кирувчи тилшунослар, шу жумладан Э. Гауэрз $^{2}$, А. Маркуордт ${ }^{3}$ ва бошқалар умумжамоа томонидан қўлланиладиган ва тил жамияти томонидан тўғри деб қабул қилинган тил шакл ( форма) лари деб тушунадилар. Бошқача қилиб айтганда, уларнинг фикрича тил ходисаларининг умумқўлланилиши уларнинг нормативлигидан далолат беради. Бу фикр биринчи бўлиб инглиз тилшунослигида Р. Тренч томонидан айтилган эди. Жумладан, у шундай ёзади: “...тилнинг тилшунос хохлаган элементлари эмас, балки тилда хақиқатан хам нима мавжуд ва ишлатилаётган бўлса ўша тўғридир".

Шундай қилиб, чех тилшунослари, америкалик тадқиқотчилар, инглиз ва немис тилшунослари хамда Э. Косериунинг “тил нормаси” тушунчасини илмий - назарий 
жихатдан тахлил қилишлари, бу тушунчанинг жуда кўп белги ва мезонларини, ўзига хос хусусият ва хоссаларини аниқлашда беқиёс катта ахамиятга эгадир. Аммо улар норма тушунчасини аниқлашда категориал даражадаги мукаммал фикрга кела олмадилар.

Адабиётлар:

1.Бегматов Э., Маматов А. Адабий норма назарияси. 1-қисм.Т.: 1997,11 б.

2.Пражский лингвистический кружок. М.: 1967, 340 с.

3.Барнет В. Языковая норма в социалной коммуникации. Проблемы нормы в славянских литературных языках в синхронном и диахронном аспектах. М.: 1976, с. 48.

4.Косериу Э. Синхрония, диахрония и история. Новое в лингвистике. Вып.3. М.: 1963

\section{FRANSUZCHA VA O'ZBEKCHA RASMIY HUJJATLARNING TEXNIK XUSUSIYATLARI}

\section{Samarqand davlat chet tillar instituti talabasi Ilmiy rahbar: f.f.n., dots. Suvonova N.N. Email:suvonova@samdchti.uz}

Annotation: Ushbu maqolada fransuz va o'zbek tillarida yaratilgan rasmiy-idoraviy hujjatlarning texnik xususiyatlari va hujjatlarda tinish belgilarining qo'llanilish holatlari tahlil qilingan.

Key Words: texnik xususiyatlar, tinish belgilar, nuqta, vergul, ikki nuqta, ko'p nuqta, nuqtali vergul.

Fransuz va o'zbek tilida rasmiy uslubda yoziladigan hujjatlarni yozishda leksik, grammatik qoliplarga bo'ysunish bilan bir qatorda, ma'lum texnik qonuniyatlardan ham chetga chiqib keta olmaymiz. Ularnining bir qancha shakliy xususiyatlari ham mavjud. Quyida ularni ko'rib chiqamiz.

Ish qog'ozlari, odatda siyohli, sharikli ruchkada (ko'k, qora, gunafsharang sterjen bilan) aniq dastxat bilan yoziladi. Ariza, tarjimayi hol, bildirgi (raport) kompyuterda yozilmay, faqat qo'l bilan yoziladi. Ammo bugungi kunda imkon boricha vaqtni tejash hamda turli xil yuzaga kelishi mumkin bo'lgan tushunmovchiliklarni oldini olish maqsadida turli xil tashkilotlar shu sohaga mao ravishda tayyor ariza anketalarini ishlab chiqqan. Ish qog'ozlarining har bir turi umum qabul qilingan shaklda va muayyan izchillikda tuziladi. Hujjat matni qisqa, ravon, aniq va mantiqli (ortiqcha so'z va iborasiz) bayon qilinishi kerak. Hujjat tili juda lo'nda bo'lishi lozim.

Son, odatda, raqam bilan yoziladi. Pul hujjatlari (dalolatnoma, ishonchnoma, tilxat)da raqamdan so'ng qavs ichida shu raqamning so'zdagi ifodasi ko'rsatiladi.

Arab raqamlari bilan ifodalangan tartib sonlardan so'ng qo'shimcha yozilmay, uning o'rniga defis (-) qo'yiladi: 3-chorak, 4-kurs. Rim raqamidan so'ng hech qanday qo'shimcha yozilmaydi: I chorak, II kurs.

Turli belgi va son ifodalari bir xil shaklda yoziladi. Masalan №, §, \%, (telegrammalarda bular so'z bilan - raqamli, band, foiz kabi ifodalanadi.)

Hujjatlarda sanalar arab raqami bilan yoziladi. Bunda ruscha shaklda - 15.11.04; 02.08.04 tarzda emas, balki quyidagi o'zbekcha gap tuzilishidan kelib chiqqan shaklda berish kerak: 1991.04.09; 2004.04.09. Bunda dastlabki to'rt raqam yilni, keyingilari kun va oyni bildiradi.

Rasmiy-idoraviy hujjatlarni tayyorlashda uning zaruriy qismlari joylashishiga, matn mazmuni tarkibiy qismlarining ketma-ketligiga, tinishbelgilarining to'g'ri qo'yilishiga alohida e'tibor berish lozim. Hujjat matnida vergul, nuqtali vergul, ikki nuqta, qavs, tire nisbatan faol ishlatiladi.

Fransuzcha rasmiy hujjatlar va maktublarning shakl jihatdan tahlili haqida mulohaza yuritsak, albatta, tinish belgilarining ishlatilishiga to'xtalib o'tishimiz zarur deb hisoblaymiz. O'zbek tilidagi tinish belgilarining ishlatilish qoidalari bilan fransuz tilidagi qoidalar bir-biriga 
yaqin bo'lsa-da, fransuz tilida o'ziga xos xususiyatlar ham bor. Shuning uchun fransuz tili misolida ham rasmiy hujjatlarda tinish belgilarining ishlatilishini ko'rib chiqamiz. Punktuatsiya matn elementlari va qismlari o'rtasida muhim aloqani ta'minlash bilan bir qatorda, matlarda, ayniqsa, rasmiy hujjat va maktublar matnida paydo bo'lishi mumkin bo'lgan xatolarni oldini olish hamda matn mazmunini no'to'g'ri tahlil qilishni oldini olishga xizmat qiladi. Quyida punktuatsion belgilarni ishlatilishini qisqacha ko'rib o'tamiz.

Nuqta (le point) gapning tugallanganligini ko'rsatadi. Qisqartma so'zlardan so'ng nuqta qo'yiladi. Agar qisqargan so'z gap oxirida kelgan bo'lsa, gapning tugaganligini anglatishga xizmat qilgan nuqta qo'yilmaydi. Masalan : À cette réception, il avait vu des personnalités très diverses : écrivains, députés, animateurs de télévision, sportifs, etc.

Vergul (le vergule) bitta sodda gap yoki ergashgan gap tarkibidagi elementlar orasidagi qisqa pauzani ko'rsatadi. Vergulning ishlatilishi gapning mazmuniga bevosita ta'sir ko'rsatadi.

Quyidagi ikki gapda vergulning ishlatilishining gap mazmuniga ta'siri bilan bo'gliq bo'lgan holat mavjud.

Masalan: Les États membres, qui respectent les critères de convergence, peuvent accéder à la monnaie unique. (Tous les pays peuvent accéder à la monnaie unique parce qu'ils respectent les critères._LLes États membres qui respectent les critères de convergence peuvent accéder à la monnaie unique. (Seulement les pays qui respectent les critères peuvent accéder à la monnaie unique.) Uyushiq bo'laklar orasida vergul ishlatiladi. Masalan: Arthur, Oscar, Frédéric, sont de bons ouvriers.

Nemis tiliga qarama-qarshi ravishda fransuz tilida o'zbek tilidagi kabi matnda uchraydigan o'zlashtirma gapning qismlari orasida vergul bo'lmaydi. Masalan : Il disait qu'il ne pouvait pas venir. (Pas de virgule avant que)

Er sagte, dass er nicht kommen könne. (Virgule avant dass)

U kela olmasligini aytardi.

Nuqtali vergul (le point-vergul) gap mazmunining yanada tushunarli bo'lishini ta'minlash uchun vergullar bilan ajratilgan qismlar orasida qo'llaniladi. Masalan :C'était une personnalité tyrannique, autoritaire et peu encline au dialogue ; d'ailleurs, nombreuses furent les personnes, de tous les milieux, qui le lui firent remarquer.

Ikki nuqta (les deux points) ko'chirma gapda muallif gapidan keyin ishlatiladi. Masalan : Chacun se demandait : "À quoi cela sert-il ? »

Uyushiq bo'laklar oldidan: Les principaux cours d'eau de la France sont : la Seine, la Loire et le Rhône.

Ko'p nuqta (les points de suspension) agar uyushiq bo'laklarni sanash tugallanmagan bo'lsa qo'yiladi. Masalan : À cette fête, il y avait des invités prestigieux : ministres, députés, consuls, ambassadeurs...

Tugallanmagan fikrni ifodalaydi. Masalan: Il y avait cent... disons cent-vingt invités présents à la réception.

Ba'zan rasmiy hujjatlarda yoki maktublarda kishilar ismi yoki korxona-tashkilotlar nomi yashirin saqlash zaruriyati tu'giladi, shunday hollarda soz'lar bosh harflaridan so'ng ko'p nuqta ishlatiladi. Masalan : Le sous-directeur S... a beaucoup fait parler de lui. Plainte contre X...

Shu bilan birga rasmiy matnlarda qavs (le parenthèse), to'rtburchak qavs(le crochet), tire (le tiret), qo'shtirnoq (le guillemet) kabi punktuatsion belgilar ko'p ishlatiladi. Masalan : Le propriétaire de la maison n'avait pas entendu le cambrioleur. (Il faut dire qu'il était assez sourd.) Ce n'est pas une surprise de voir l'Alsace (deux départements [Bas-Rhin etHaut-Rhin] avec Strasbourg comme chef-lieu) arriver en tête dans cette statistique. Il était intelligent - aucun doute à avoir à ce sujet -, mais ses propos étaient dépourvus de subtilité.L'enfant racontait avoir vu une « girafle » et « une » crocodile au jardin zoologique.

\section{Hujjat matnini tuzishda quyidagilarga amal qilish zarur:}

- hujjat jo'natilayotgan (yozilayotgan) tashkilot nomini, mansabdor shaxs ismi, otasining ismi va familiyasini rasmiy nomlanishlariga to'la muvofiq holda yozish; 
- hujjat turiga muvofiq uning zaruriy qismlarini o'rniga muvofiq joylashtirish, tartibi, harflar hajmini to'g'ri belgilash; (O'zbek tilida asosan kompyuterda yoziladigan hujjatlar Times New Roman shriftida, 14 o'lchamda 1 yoki 1.5 intervalda yoziladi. Fransuzcha rasmiy hujjatlar, maktublarda asosan Calibri, shu bilan birga, Arial, Book Antiqua, Century, Verdana, Garamond, Times New Roman shriftlaridan foydalaniladi. Matn 12-13 shrift o'lchamida, 1-1,5 intervalda bo'ladi.)

- so'zlar va gaplarda imlo me'yorlariga amal qilish, tinish belgilarni o'z o'rniga to'g'ri qo'yish, tuzatish yoki o'chirishlarga yo'l qo'ymaslik;

- matnning yozilish sanasini, imzolovchi shaxs lavozimi va ismi familiyasini aniq ko'rsatish. Masalan: 2004-yilning 18-oktabri, «Hashar» shirkati raisi Said Olimov kabi. Fransuz tilida esa sana "Le 21 mai, 1997" shaklida yoziladi.

\section{Adabiyotlar :}

1. Keldiyorova G.S, Ablayeva N.A., O'zbek tilida ish yuritish, Toshkent: ToshKTI, 2009.

2. AUMONT M., CUSSEC., etc, La correspondance administrative, Académie d'Orléans, Tours, 2000.

3. Guide de rédaction.Éditeur service information et presse layout vidale-gloesener graphic design impression imprimerie fr. Faber, mersch. 2e édition revue, septembre 2006.

\section{ИЗХОРЛОВЧИ ҚУРИЛМАЛАР ПЕРИФРАЗАЛАРИ ХАҚИДА МУЛОХАЗАЛАР}

\section{Самарқанд Давлат Университети ўқитувчиси Email: mardiyevb @mail.ru}

Annotation: The most important means of organizing synonymous relationships in syntax are periphrases along with transformations. A periphrasis is a speech device of one form (thought, phrase) that expresses the original (detonative) meaning in terms of contentIn terms of grammatical-syntactic structure of a sentence, one of the two sentences differs from the other in their structural-semantic structure. The signifiable difference of the two expressions at the syntactic level is in their different structural-semantic structure.

Key words : periphrase, transformation, denotation, signifat, exclamatory, attribute.

Хозирги ўзбек адабий тилида изхорловчи қурилмалар перифразаларининг бир неча типлари мавжуд.

Перифразанинг асосий типи изхорлаш семантикаси предикатида обектли позицияни эгалловчи изхорловчи қисмнинг хосил бўлиши билан боғлиқ, изхорловчи қисм предикати хусусий субектда атрибутга айланади, тобе қисм субекти бевосита асосий предикатнинг обекти хисобланади. Мисоллар:

Янги туцданинг боши ким-у, рахнамоси ким еканини билмас еди, аммо рақибига орқадан урилган тиғ унга жуда ёқди (Т.Малик. Шайтанат).

Хиргохдан югуриб чиққанлар яланг бош ва яланг оёқ шахзодани кўриб, ханг-манг бўлиб қолдилар (Х.Султонов. Бобурийнома)

Очликдан дармони куриб йиқилган ва хатто ўлиб қолган одамларни ўз куцзи билан курган еди, дийдаси қотгани сабаби хам -шу (Т.Малик. Шайтанат).

Ёв қалъага яқинлашган еди, шу сабабли тиғ кутариб, қиличларини қинларидан суғуриб овозларининг борича бақириб кохорталарини олға ундаган аскарбошиларни курди (М.Булгаков. Уста ва Маргарита).

Келтирилган хар бир мисолга муносабатда синтактик структура аниқловчи оборотли предметли тўлдирувчига изхорловчи феъл-гапнинг семантик мазмуни тўлиқ айнан бир хилдай кўринади. Аммо бу бундай эмас.

Биринчи мисолда асосий қисм субектига албатта, “зарба” емас, балки зарба бериш далили ёқади. Бундай семантикага нисбатан оддий (грамматик ядроли) тип структураси жавоб беради: “унга рақибига тиғ урилгани жуда ёқди”.

Учинчи мисолда изхорли предикат субектини бундай одамлар емас, балки очлик 
туфайли толиққан инсонларнинг йиқилиши егаллайди. Бунга нисбатан семантик жихатдан аниқликни ифодаловчи "у одамларнинг... очликдан дармони қуриб йиқилганини ва хатто ўлиб қолганини... кўрган еди” жумласи мос келар еди.

Тўртинчи мисолда маълумотнинг асосий мазмуни Берунийнинг аскарбошиларни кўргани емас - у уларни кўриши, улар ўртасида содир бўлган тортишувни кўриши керак еди: “...аскарбошининг бақираётганини кўрди”.

Бошланғич ядровий препредикатив-обектли изхорловчи қурилма (иқ) ларни бадиий адабиётдан келтирилган мисолларда ифодаланган префразалар билан таққослаш қуйидагиларни кўрсатади. Ядровий структуралар хозирги, ўтган ва келгуси замондаги харакатга, реал ва реал далилларга диққатни жамлайди. Перифразанинг коммуникатив вазифаси нутқ субекти (муаллиф)нинг бу харакат туфайли еришган (еришаётган ёки еришадиган) натижаларга диққатини жамлаш истаги хисобланади, бу тобе синтагма субектида харакат жараёнида содир бўладиган ўзгариш билан боғлиқ холда амалга ошиши мумкин, бу на перифразалашган қурилма унинг харакат натижасида еришилган мохияти, сифати тарзида намоён бўлади: “зарба бермоқ", “берилган зарба”, “ўлаётган одамлар”, “ўлган одамлар”ва шу кабилар.

Кейинги келтирилган мисолда бошланғич қурилма учун “ешитмоқ" феълли предикатни назарда тутамиз: аскарбошиларнинг сўкинаётганини ешитди. Аммо перифраза ўтишда изхорлаш семантикаси феълида обектли позисияни предикат емас, субект егаллай бошласа, изхорли феълнинг (ешитмоқ, кўрмоқ) лексик характерини ўзгартиришга тўғри келади, сўзловчининг нутқий фаолиятини фақат ешитиш мумкин, турли шу жумладан, нутқий харакатни амалга оширган субектнинг ўзини кўриш мумкин.

Ўхшаш структур перифразаларининг кўп сонли еканлиги ноаниқ семантикали отнинг умумий бутун холатнинг ноаниқ белгиланишининг номинатив мазмуни обектли позицияда еканлигида хосил бўлади. Бу отли тип “воқеа ", “тур ",“кўй ", ахвол " хол ","одат", гап ", фикр "ва шу кабилар.

Кеча билан уззмни яна дарс тайёрлаб уттирган холда куцриб қоламан (Ғ.Ғулом).

... Бу ерда бўлиб ўтган дахшатли воқеаларни ўз кўзим билан кўрганман (Ш.Рашидов).

С.Н.Иванов ва Е.А.Поселуевский каби олимлар бундай қурилмалар тахлилига алохида эътибор қаратдилар, аммо улар бу тузилмага уларнинг ядровий структураси, яни перифразаларга мувофиқлик нуқтаи назаридан қарамадилар. Вахоланки бундай мувофиқлик шубхасиз: “мен ўйладимки...”,"калламга шу хұақда фикр келдики...”, ”у сўзлагани хзқида еслади”, “у унинг ---хақидаги сўзини еслади”ва шу кабилар.

Перефразанинг яна бир кўриниши изхорлаш семантикасининг асосий предикати обектли позицияда тобе қисм обекти чиқиши туфайли содир бўлади, тобе қисм предикати ўз субекти билан хусусий обектда аниқловчили оборотга айланади. Мисоллар: Ўтгандан, кетгандан гапиришдилар, гап айланиб Дукчи Ешон воқеасига тақалди, бу тўғрида хамма ўз билгани, ўз кўргани ажойиблардан сўзлади (Ғ.Ғулом).

Бу нотаниш одамнинг хатти-харакати поччани қаттиқ хайратга солди, ичида унинг Берлиознинг хотирасига кўрсатаётган хурматига қойил қолди (М. Булгаков. Уста ва Маргарита).

Кўрилган типлардаги перефразаларнинг бошланғич қурилмалардан мухим структур-семантик фарқи шундаки, гап - перефраза полипредикатив хосила хисобланмайди, синтактик (структур) сатхда у мано предикатив. Айни вақтда денотатив босқичда бундай гапларда хусусий субектли-предикатли структурали икки холатда етказилади масалан: “ македонияликлар рўмолларини силкитадилар, буни қўриқчилар кўради” улар илгари хар хил ажабланарли нарсаларни кўрганлар ва улар бу хақда хозир хикоя қиляптилар.

Перифразалар-кенгайиши, изхорловчи қурилмаларнинг структур-семантик қайта қурилиши перифразаларнинг хосил бўлишига олиб келади, бу холатда вазиятга боғлиқ 
бўлган, мазмуни, маъноси муайян матнгагина алоқадор бўлган индивидуал перифразалар намоён бўлади. Жумладан, изхорловчи қурилмаларнинг структурсемантик қайта қурилиши асосий қисмга -жумланинг изхорланувчи қисмига хам таъсир қилиши мумкин. Бундай холларда изхорловчи семантик предикати субект олдида атрибутив шаклда (сифатдош) қайта тузилади ва шу туфайли янги предикат пайдо бўлади; тўлдиришда икки холатда (изхорловчи ва изхорланувчи) ўхшаш шакл яна учинчисини қабул қилади. Модомики дастлабки жумлага нисбатан янгиси денотатив маънони сақлаб қолар екан, ўзгартирилган структур-семантик ифодада у перифраза хисобланади; аммо мазкур перифраза зарурият туфайли янги мазмунни қамраб олади, шунинг учун мазкур тип перифразани изхорловчи қисм қайта тузилиши билан боғлиқ юқорида тавсифлангандан фарқлаш учун биз уни шартли равишда перифраза кенгайиш деб номлаймиз. Мисоллар:

Яхши куролланган бехисоб душман лашкарининг яқинлашиб қолганидан дарак топган Нуёен Бобурмирзо билан маслахатлашишга улгурмасдан қалъадан узоқдаги тоғларга чекинишга мажбур бўлди (Х.Султонов. Бобурийнома).

Инсоннинг бу даражада хор бўлиб кетганини кўрган қоровулнинг кўнгли бўшаб, расмиятдан чиқди (Мирмухсин).

Изхорлаш семантикасининг таянч сўзи ва изохловчи қисм ўртасидаги муносабат перифраза-кенгайишда дастлабки изхорловчи қурилмадагидай қолади, фақат изхорловчи қисм предикат олдидаемас, атрибут олдида бўлади. Шунинг учун яхлит жумла нуқтаи назаридан емас, унинг изхолрлаш муносабатини етказувчи қисми нуқтаи назаридан бундай қурилма приатрибутив деб аталиши мумкин, бунда у қолган шу маънода припредикат ёки айрим холларда присубект хисобланувчи барча дастлабки изхорловчи қурилмалар ва преифразалар типларидан фарқ қилади.

Иқ (изхорловчи қурилма) таркибида сифатдош оборот ўз субектига нисбатан оддий аниқловчи емас, балки унинг гапдаги роли мураккаб. Бундай турдаги гапларга икки холатда таллуқли: бири - изхорлаш холати (ўзи икки вазият, холатнинг бирикиши хисобланади), бошқаси -қандайдир бошқа. Бу боғланишда бўлиш бу холатлар учун субектнинг битталиги туфайли содир бўлади. Изхорлаш холати - маълумот ёки идрокни нимадандир олиш ёки бирор сабаб бўйича қандайдир хис-туйғунинг хосил бўлиши хақиқатан хам қўзғатувчи туртки, шу субектни қандайдир харакатга ундовчи импулс хисобланади. Шунинг учун ИҚформал босқичда аниқловчили оборот сифатида семантик жихатдан мураккаблашган гапнинг асосий предикатига нисбатан сабаб асоси вазифасини бажаради.

\section{Адабиётлар:}

1. ИвановС.Н. Очерки по синтаксис узбекского языка. Л., 1959, с.59-60;

2. ИвановС.Н. К проблеме придаточных предложений в тюркских языках. (Изъяснителные причастные конструксии в узбекском языке и вопрос о трансформах //Тюркологический сборник. 1977. -М.,1981;

3. Степанов Ю.С. Имена, предикаты, предложения. -М., 1961,с. 201-211

4. Тоғай Мурод. Отамдан қолган далалар. (роман). -Тошкент: «Шарқ» нашриёт-матбаа аксиядорлик компанияси бош тахририяти, 1994.

5. Тохир Малик. Шайтанат.Қисса. Биринчи китоб. -Тошкент: «Шарқ» нашриёт-матбаа аксиядорлик компанияси бош тахририяти, 1994.

6. Хайриддин Султон. Бобурийнома. Маърифий роман. -Тошкент: «Шарқ» нашриёт-матбаа аксиядорлик компанияси бош тахририяти, 1994. 
FRAZEOLOGIYADA MILLIY OLAM TASVIRI

(fransuz va o'zbek xalq maqollari misolida)

\section{Aliyeva Gulzoda Tulqinovna \\ Samarqand davlat chet tillar instituti o'qituvchisi \\ Email:aliyeva@samdchti.uz \\ Aliyeva Nargiza Tulqinovna \\ Samarqand viloyat Oqdaryo tuman \\ 38-maktab o'qituvchisi}

Annotation: In this article it has been given ideas on some ways of translating Uzbek folk proverbs into French. It has been paid special attention especially on the translation of Uzbek folk proverbs into French that it should be kept transparency of their full meaning and content. From this point of view, it has been considered that Uzbek proverbs expressing national value from the point of their expression different themes and the usage of different national lexis.
Key words : Uzbek folk proverb, national vocabulary, national outlook, rhyme and melody, complete thought, national value.

Turli xalqlarning madaniyatlari va milliy olami frazeologik birliklar bilan aks ettirilishi o'ziga xos obrazli hisoblanib, bunday ifoda birliklarning qo'llanilishi har qanday millatga mansubdir. $\mathrm{Bu}$ esa chet tilidagi frazeologik birliklarning mazmun mohiyatini tushunishda muammolar uyg'otadi. Frazeologiya har qanday tilda obrazlilik va yorqin ko'tarinkilikni ifodalab, ular xalqning milliy xususiyatlarini xarakterlaydi, ular turli xildagi ekspressiv bo'yoqdorlikni o'zida mujassam etib, hamda u konteks ta'siri ostida qo'shimcha ma'noni anglatib keladi. Frazeologiyada ikki tilda umumiy xususiyatlari va farqli jihatlarining o'rganilishi mazkur so'zlashuvchi xalqlarning milliy mentaliteti va dunyoqarashini tushunishga yordam beradi. G.F.Ustinning bu boradagi fikricha , "Umumiy madaniy muloqot jarayonidagi asosiy to'siq o'zaro muloqotga kiruvchi turli madaniyatlarning o'ziga xos milliy xususiyatlariga bog'liqdir". $\{1 ; 76\}$

Har qanday xalqning ham ma'naviy-ma'rifiy, ham ijtimoiy hayotida frazeologizmlar keng qo'llaniladi. Dastlab, frazeologiyaning hajmini toraytirib, faqat iboralarning o'zini o'rganish lozim deb, maqol, matal va hikmatli so'zlarni frazeologiyaga kiritmaganlar. Boshqa fikr tarafdorlari esa, iboralardan tashqari, ham maqol-matallarni, ham aforizmlarni frazeologiyaning hajmi doirasiga kiritishgan. G'.Salomov "frazeologizmlar (maqol, matal va iboralar)ning ma'nosi konteks ichida ochiladi"(2.118) degan fikrlari bilan qaysidir ma'noda frazeologiya chegarasini belgilab bergan.

Tilimizning, qolaversa, nutqimizning ziynati hamda ko'rki hisoblangan maqollarning tilda tutgan o'rni, shuningdek, ularning lingvistik mohiyatini ochish va tavsiflash orqali biz frazeologiyaning kommunikativlik xususiyatini yoritamiz. Zero, nutqimizni tilda mavjud maqol va matallarsiz tasavvur qilish qiyin. Binobarin, maqol va matallar til frazeologik sistemasining har tomonlama eng boy va eng serqirra manbai bo'lib hisoblanadi. Maqollar A.V.Kunin tomonidan frazeologik birlik sifatida talqin etiladi. Shuningdek, A.V Kunin maqollarni kommunikativ xususiyatga ega bo'lgan frazeologik birliklar sifatida tavsiflaydi. Maqollar frazeologiya sistemasiga xos kommunikativlik hodisasining eng asosiy namunasi, qolaversa, tayanch nuqtasi bo'lib hisoblanadi. Fransuzcha maqollarni o'rganish fransuz tilini o'rganish va o'rgatishda ham muhim ahamiyat kasb etadi. Xususan, badiiy matnlarni o'qib tushunish jarayonida, ularni tarjima qilish davomida, shuningdek, tilni o'quvchi yoki talabalarga o'rgatish jarayonida ham katta yordam berishi mumkin. Shu bilan birgalikda, maqollarni chuqur o'rganish og'zaki nutqimizning rivojlanishida ham muhim o'rin tutadi. Maqol deganda, dastlab, ko'z oldimizda xalq donishmandligining nodir na'munalari namoyon bo'ladi. Ular ijtimoiy va maishiy hayotning turfa sohalarini qamrab oladi. Zero, maqollar xalqning asrlar davomida 
to'plagan tajribalarini, ijtimoiy-siyosiy, ahloqiy va falsafiy qarashlarini qisqa satrlarda badiiy tarzda ifoda etadi. Biz fransuzcha maqollarni tahlil qilish jarayonida bir necha turfa mavzularni o'zida mujassam etgan maqollarga duch keldik. Xususan, Vatan va vatanparvarlik, mehnatsevarlik va ishyoqmaslik, halollik va tekinxo'rlik, to'g'rilik va o'g'rilik, yaxshilik va yomonlik, yaxshi so'z va yomon so'z, do'stlik va dushmanlik, tinchlik va notinchlik, botirlik va qo'rqoqlik, donolik va nodonlik, odob va odobsizlik, mehmon va mehmondo'stlik, saxiylik va baxillik, go'zallik va xunuklik, kamtarlik va manmanlik, baxt va baxtsizlik, epchillik va noshudlik, sabr va sabrsizlik, muhabbat va bevafolik, tamagirlik va ochko'zlik, umid va ishonchsizlik, taqdir va hayot, imkon va imkonsizlik, ehtiyotkorlik va ehtiyotsizlik va boshqalar shular jumlasidandir. Bizga ma'lumki har bir xalq o'zining milliy olami bilan boshqa bir xalqdan ajralib turadi. Ba'zan shunday maqol va hikmatli so'zlarga duch kelamizki ularning aynan boshqa tilga o'z asli kabi tarjima qilishga imkoni bo'lmaydi. Chunki u yerda keltirib o'tilgan elementlar aynan shu xalqning o'zigagina tegishli bo'ladi. Quyida bir nechta o'zbek xalq maqollarini misol tarzda keltirib o'tsak.

\begin{tabular}{|l|l|}
\hline Sichqon sig'mas iniga, g'alvir boylar dumiga. & $\begin{array}{l}\text { La souris ne rentre pas son trou, mais elle } \\
\text { attache à sa queue un tamis. }\end{array}$ \\
\hline Qaytib ochar qopqangni qattiq yopma. & $\begin{array}{l}\text { Ne claque pas la porte dans la maison où } \\
\text { tu es susceptible de revenir. }\end{array}$ \\
\hline $\begin{array}{l}\text { Pichoq o'tkir bo'lsa ham , o'z -sopini } \\
\text { kesmaydi. }\end{array}$ & $\begin{array}{l}\text { Le couteau bien aiguisé ne doit pas couper } \\
\text { son étui. }\end{array}$ \\
\hline Palovning qamchisi-choy. & Le thé, c'est la cravache du pilaf. \\
\hline Oti-ulug', suprasi-quruq. & $\begin{array}{l}\text { Son titre est supérieur, sa table est maigre. } \\
\text { On ne peut pas fermer la bouche du peuple } \\
\text { El og'ziga elak tutib bo'lmas. }\end{array}$ \\
\hline
\end{tabular}

Yuqorida keltirilgan maqollar o'zbek xalq milliy maqollari bo'lib ularda keltirib o'tilgan elementlar hech bir xalq maqolida uchramasligi mumkin. Misol uchun maqollarda keltirib o'tilgan g'alvir, qopqa, sop, palov, supra, elak so'zlari aynan o'zbek tiliga mos va ular milliylikni bildiruvchi so'zlar hisoblanadi. Maqollardan inson nafaqat odob ahloqni balki shu xalqga doir urf odat va madaniyatni ham o'rganishi mumkin.

\section{Адабиётлар:}

1. Кунин А.В. Курс фразеологии соврменного английского языка. - Москва: ВШ, 1986. - 336 с.

2. Носиров А. Француз, ўзбек ва рус тилларидаги провербиал фразеологизмларнинг семантикстилистик ва миллий-маданий хусусиятлари.10.00.06.Қиёсийадабиётшунослик, чоғиштирма тилшунослик ва таржимашунослик. Фил.фан.док.... автореферати. -Т., 2016. -95 б.

3. Ergashev M., Niyozov I. Proverbes et Dictons d'Ouzbékistan.-Paris:EDITIONS GEORAMA,2006.-96 p.

\section{ЭРТАКЛАРЛАРНИ ТАЛҚИН ҚИЛИШГА ОИД ЁНДАШУВЛАР ХУСУСИДА}

\section{Кўчқорова Садоқат Тошпулатовна Самарқанд давлат чет тиллар институти докторанти Email:kuchkarova@samdchti.uz}

Annotation: This article is about different approaches of the interpretation of Frenche tales. We analyze cosmological, meteorological and ritual approach for the interpretation of symbols from Perrault's tales.
Key words : tale, fairy tale, approach, rites, mythological consciousness

Халқ оғзаки ижоди намуналари бўлган эртаклар талқинига турлича ёндашув Европада ривожланди. Сехрли эртаклар таркибида, улар дунёнинг қайси мамлакатига тегишли бўлмасин, гарчи турли худудлар ахолиси бир-бири билан алоқа қилмасаларда, бир пайтнинг ўзида бир хил мотивлар учраганлиги кўп бор тадқиқ қилинган. Баъзи олимлар ушбу холатга барча қитъалардаги инсонларнинг хар томонлама эволюция жараёни бир пайтда ва бир тарзда кечганлигини асос қилишади. Баъзи муаллифлар эса, 
эртакларнинг, айниқса, сехрли эртакларнинг “соддагина” кўринишига қарамай, инсон онгини сехрлаб қўядиган, биз ўйлаганимиздан анча кучли бўлган “жодуси” хақида гапиришади. Француз фольклористи Маргерит Делашо [1,1949] "миф, эртак ва афсоналар бир нечта калит орқали ойдинлаштирилиши” кераклигини таъкидлайди. Худди шундай, Ф. Флао ${ }^{1}$ узоқ ва сирли ўтмишга эга эртакларнинг, инсон ўй-фикрлари, энг чуқур ғам-андухларини кўзгу сингари акс эттирадиган “қиёфали тили” мавжуд эканлигини айтади. Эртаклардаги рамзларни англаш учун турли ёндашувлар қўлланилган. Француз эртакчилигида Ш. Перро эртаклари мифологияга асосланган космологик, метеорологик [2,1874] ва ритуал ёндашуворқали талқин қилинган. Мифологияга асосланган космологик-метеорологик талқин асосида эртакларни табиатга хос бўлган ходисалар (кун чиқиши ва ботиши, қуёш ва ойнинг харакати) воситасида изохлаш ётади. Аксарият француз олимлари ушбу ёндашувларга материал сифатида Ш. Перронинг Le petit Chaperon rouge (Қизил қалпоқча), La belle au bois dormant (Уйкудаги малика), Cendrillon (Сендрелла ёки Кулойим), Le petit Poucet (Кичкина Пусэ), Barbe-Bleue (Кўк соқол) эртакларини тахлил қилганлар. Мифолог Гиатцин Юссон (Hyacinthe Husson) Le petit Chaperon rouge (Қизил қалпоқча) эртаги бош қахрамони қизил қалпоқчали қизалоқни хар куни эрталаб кўтариладиган қизил қуёш, у бувиси учун олиб бораётган егуликни қуёш инсонларга улашаётган нур, қизалоқни еб қўйган бўрини қуёшни ютиб юборган тун сифатида талқин қилади. La Belle au bois dormant (Уйкудаги малика) эртагидаги ухлаб ётган малика - тинч-осуда тун, кўркам шахзода эса кундузнинг тимсолидир. Малика уйқудалигида унинг саройи атрофидаги кириб бўлмас чангалзордан йўл очилиб, шахзоданинг кириб келиши тонг отишидаги қуёшга ишора қилинади. Худди шу манзарани фасллар кесимида олинса, қишдаги узоқ уйқудан кейинги ернинг бахорда уйғониши аломати сифатида талқин қилинади. Cendrillon (Сендрелла ёки Кулойим) образи хам бирдан ёниб ўчиб, шахзодага турмушга чиққандан сўнг ёғдусини қайта таратган шуъла, яъни кўтарилаётган қуёш рамзини билдиради. Le petit Poucet эртагининг бош қахрамони бош бармоқдек келадиган митти бола ўз акасингилларини қутқариш учун тунни билдирадиган қоронғу ўрмон бў̆̆лаб сепиб борган майда оқ тошларни юлдузларга, ушбу тошчалардан пайдо бўлган йўлак - Сомон йўлига солиштирилади. Яқинларини иккинчи марта қутқараётган болакай сепган нон ушоқларини еб қўйган қушлар - юлдузларни бекитиб қўйган булутларга қиёс қилинса, Пусе ва ака-укаларини паққос туширмоқчи бўлган дев ямлаб ютувчи қуёшни ифодалайди. Худди шу тарзда, хотинларини бирин-кетин жонига қасд қилган Кўк соқолнинг олтинлари кундузни, ўлдирилган хотинлар ямловчи қуёш, яъни Кўк соқол томонидан йўқ қилинган юлдузлар рамзи сифатида талқин қилинган. Хақиқатдан хам, табиат ва осмон ходисалари эртакларнинг пойдевор манбасидир ва улар хар доим уларнинг рамзий тизимида мавжуд бўладилар.

Эртак ўзида илк ижтимоий жамият тузилмаларининг изларини сақлайди. В. Пропп [3, 1928] эртакдаги ана шундай хусусиятларни ажратиб кўрсатади. Улар асосан, бағишлов маросимлари, бир ёш давридан, холатдан бошқа бир ёш даврига, холатга ўтилаётганда уюштириладиган маросимларга боғлиқ бўлган.Француз фольклоршуноси П. Сентив [4, 1987] Перро эртакларини ритуал ёндашув орқали талқин қилди.

La Belle au bois dormant (Уйкудаги малика) эртагидаги малика янги йилни билдиради. Чунки, эртакдаги шох қизи халок бўлмаслиги учун отаси таъқиқлаган ип йигириш харакати, хосилга зарар келтирмаслиги учун таъқиқланадиган янги йил удумларидан эди. Шунингдек, гўзал шох қизи ухлаётган саройни ўраб олган ўрмон ва шахзода хам ибтидоий жамиятда мавжуд бўлган шох-шаббалар орасига бекиниб, рамзий фош бўлишни кутиш таомилига бориб тақалади. Шахзода маликани хушига келтириш учун олган бўса хам, бахорда бўлиб ўтадиган маросимлардаги хатти-харакатлар инъикосидир. 
Сентивнинг талқинича, Cendrillon (Сендрелла ёки Кулойим) эртагидаги Кулойим Карнавал (инсонларни бирлашишга чақирадиган ва хосилдорлик учун маросим) мавжуд замондаги қўриқчи фаришталар культини ифодалайди. Ўша даврларда, февраль ойида ўтинлардан қолган кул Карнавал маросимининг асосий элементларидан бўлган ва бу давр унашишлар даври хисобланган. Эртакдаги ўгай она эски йилни билдирса, икки ёвуз ўгай опа бахоргача қолган яна икки ой (январь ва февраль)ни ифодалаган.

Le petit Chaperon rouge (Қизил қалпоқча) қахрамони қизалоқ хам Сентив талқинида роман қабилаларига тегишли май ойи, яъни бахорги уйғониш даври қироличасини танлаш маросимидаги қиролича рамзидир. Бу одатга кўра қишни кузатиб қўйиш оммавий байрам қилинган. Эртак бошида Қизил қалпоқчанинг бориши керак бўлмаган ўрмонга ташриф буюриши “май байрами”даги таъқиқланган ишлардан бири эди. Дархақиқат, бу одатга кўра байрамнинг маълум бир пайтида ўғил ва қиз болалар мажбуран ажратиларди. Йигитлар бу вақтда ёрларининг уйларини безаш учун шох ва гуллар йиғишга ўрмонга йўл олишарди, айнан шу дамда - апрель ойининг охири ва май ойининг бошлари, ўрмон жин-ажиналар, рух ва эльфларнинг қароргохи саналган. Ёш бир қиз ўрмонда кетаётиб, шундай сирли базмларнинг гувохига айланиши мумкин деб ишонишган. Қизчанинг қизил қалпоқчаси “май қироличаси”нинг тожини ёки унга аталган бош кийимини англатган, бувисига олиб бораётган сариёғ ва сулидан тайёрланган нон ўша давр таомилига кўра, бахор маъбудаларига аталган эхсонларга ишора қилади. Бўри эса, май байрамини бузадиган ўрмон рухлари сифатида талқин қилинган.

Barbe-Bleue (Кўк соқол) эртагидаги Кўк соқол хотинига киришни таъқиқлаган “сирли хона", ибтидоий жамиятларда аёллар ва "ғофил" бандалар кириши маън этилган “эркаклар уйини” ифодалайди. Кўк соқол эса, таомил бўйича,ушбу уйга янги келганни, синовдан ўтказиб, рамзий ўлдириб, кейин қайта тирилиши учун томоша кўрсатган жодугарга қиёс қилинган. Унинг собиқ хотинларининг деворга илинган жасадлари, ибтидоий “эркаклар хонаси”га осиб кўйилган, кишилар улардан химоя ва илхом сўраган машхур қабила рахнамоларининг устихонига ишора қилган.

Le petit Poucet эртагидаги митти бола ва ака-укаларининг ота-онаси томонидан ўрмонга ташлаб кетилиши очлик ва қашшоқлик туфайли юз беради. Аслида ушбу харакатнинг асосида юқорида таъкидлаганимиз, ибтидоий жамиятда ота-оналар ўсмир ўғил болаларини, улғайган йигит даврига ўтишлари учун сирли ўрмон ёнида қолдириб келишган. Ушбу ўрмонга бегоналарнинг кириши таъқиқланган ва бундай ишни қилган кимса жони билан хақ тўлаган. Дев билан учрашув, йўлга сочилган нарсалар воситасида уйни топиб бориш мотиви, ўсмирларнинг овчилик билан шуғулланган жамоанинг тўлатўкис аъзоси бўлиш йўлидаги зарур синовларнинг рамзи хисобланади.

Эртаклар халқ оғзаки ижодининг бир тури сифатида турли даврларда, турли маконларда кун кечирган инсонлармифологик тафаккурининг, дунёни англашдаги ўйфикрлари ва тажрибасининг махсули сифатида бебахо манбадир.

\section{Адабиётлар:}

1. Marguerite LOEFFLER-DELACHAUX, Le symbolisme des contes de fées, Paris : L'Arche, 1949

2. Hyacinthe Husson. La chaine traditionnelle: contes et légendes au point de vue mythique.Paris , Librairie A Frank, 1874

3. В. Пропп. Морфология сказки. Академия. Ленинград, 1928. - 152 с.

4. Pierre SAINTYVES, Les contes de Perrault et les récits parallèles (leurs origines), Paris : Robert Laffont, 1987.

5. Martens Charles. L'origine des Contes populaires. In: Revue néo-scolastique. $1^{\mathrm{e}}$ année, $\mathrm{n}^{\circ} 3,1894$. pp. $235-262$ 


\section{XITOY TILIDA BO'G'IN}

\section{Atamuradova Mavzuna Usmonovna \\ Samarqand davlat chet tillar instituti talabasi Ilmiy rahbar: Zang Ying 檅颖 \\ E-mail: lady.atamuradova@gmail.com}

Xitoy tili xitoy - tibet tillar oilasiga kiradi. Bu tilning yozuvi iyerogliflardan tashkil topgan bo'lib, ularni o'qish uchun maxsus transkripsiya yaratilgan. Bu transkripsiya alifbosi pinyin (汉语拼音) deb ataladi. Pinyin xitoy tilining fonetik alifbosi hisoblanadi. Pinyin rasmiy ravishda 1958-yilning 11-fevralida butun Xitoy yig ilishining 5 - sessiyasida xalq a`zolari tomonidan qabul qilingan. Pinyin sistemasi lotin harflaridan tashkil topgan bo `lib, ohanglarni maxsus yordamchi belgilar ifodalagan, lekin xitoy iyeroglifik yozuvini o`rnini bosmagan. Mustaqil yozuvga aylanmagan fonetik yozuv alifbosi bo lgan pinyin bo`g`in va so`zlarni "Pu tong hua" asosida o 'qishga yordam bergan. Putonghua umumdavlat rasmiy nutqi.

Xitoy tilini boshqa tillardan ajratib turadigan asosiy farqi, u bo'g'inlardan tashkil topgan til. Shuning uchun bu tilni o'rganishni bo'g'indan boshlash kerak. O'zbek tilida so'z yasash yoki so'zlarni farqlash uchun harflardan foydalanamiz.

Xitoy tilida bo'g'inlar bo'laklarga bo'linadi. Ular shenmu va yunmu deyiladi.

Shenmu - bo'g'in boshidagi birinchi tovush. Shenmu o'zbek tilidagi undosh tovushga to'g'ri keladi. Masalan, 妈-ma-ona. Bu ma bo'g'inidagi $\boldsymbol{m}$ tovushi shenmu. Yoki 你-ni-sen bo'g'inidagi $\boldsymbol{n}$, 好-hao-yaxshi bo'g'inidagi $\boldsymbol{h}$, 不-bu bo'g'inidagi $\boldsymbol{b}$ tovushlari shenmu bo'la oladi. Hozirgi zamon xitoy adabiy tilida, ya'ni putonghuada 21 ta shenmu mavjud. Ular b, p, m, f, z, c, s, d, t, n, l, zh, ch, sh, r, j, q, x, g, k, h.[2,4]

$\boldsymbol{b}$-portlovchi, jarangsiz, qo'sh lab tovush. Talaffuz qilinganda lablar yumilib, havo oqimi portlab chiqadi, tovush paychasi titramaydi. Masalan, 八 -ba-sakkiz, 壁 -bi-devor, 不-buyo'q.

$\boldsymbol{d}$-portlovchi, jarangsiz, til uchi tovush. Talaffuz qilinganda, til uchi tepa tishning milkiga tegadi. Og'iz bo'shlig'iga havo to'planadi va til uchi pastlab havo oqimi portlab chiqadi. Tovush paychasi titramaydi. Masalan, 打-da-urmoq, 的-ning, 大-da- katta.

Yunmu - bo'g'in boshidagi birinchi tovushdan keyin keladigan tovush yoki tovushlar yig'indisi. Yunmu o'zbek tilidagi unli tovushga o'xshaydi. Masalan, 我- wo-men bo'g'inidagi $\boldsymbol{o}$, 是 -shi bo'g'inidagi $\boldsymbol{i}$, 他-ta-u bo'g'inidagi $\boldsymbol{a}$ tovushlari yunmu hisoblanadi.

Yuqorida yunmu tovushlar yig'indisidan ham tashkil topishi aytildi, ya'ni 买-mai-sotib olmoq bo'g'inida $\boldsymbol{a i}$, 给-gei-bermoq bo'g'inidagi $\boldsymbol{e i}$, 小-xiao-kichkina bo'g'inidagi iao.

Xitoy tilida 38 ta yunmu bor. Bular a, o, e, i, u, ü, ai, ao, ou, ei, ia, ie, iao, iou, iu, ua, uo, uai, uei, ui, üe, ang, an, ong, en, eng, ian, in, iang, ing, iong, uan, uen, un, uang, ueng, üan, ün. Asosan quyidagi 6 ta yunmu orqali qo'shma va burun yunmulari hosil qilinadi: a, o, e, i, u, ü. Qo'shma yunmular: ai, ao, ou, ei, ia, ie, iao, iou, iu, ua, uo, uai, uei, ui, üe. Burun yunmulari: ang, an, ong, en, eng, ian, in, iang, ing, iong, uan, uen, un, uang, ueng, üan, ün.[2,2]

Yunmu har doim o'zbek tilidagi unli tovushga to'g'ri kelavermaydi. Chunki xitoy tilida burun yunmulari bor va ularda n, ng tovushlari ishtirok etadi. Bu tovushlar o'zbek tilida undosh tovushlar hisoblanadi. Xitoy tilida esa n yoki ng tovushlari bitta bo'g'inning ikkinchi qismida kelganligi uchun ular ham yunmu deyiladi. Masalan, 两-liang-ikki bo'g'inidagi iang, 冷-lengsovuq bo'g'inidagi eng, 零 - ling-mayda bo'g'inidagi ing yunmudir.

Yunmularsiz bo'g'in mavjud bo'lmaydi.[1,9] O'zbek tilida ham bo'g'in bo'lishi uchun unli tovush qatnashishi kerak. Undosh tovushsiz ham bo'g'in hosil bo'ladi. Masalan, o-na, u-ka, o-ta. Xitoy tilida ham shenmusiz bo'g'in mavjud. Masalan, 啊-a, 饿- e-och qolmoq, 爱-ai - yaxshi ko'rmoq. 


\begin{tabular}{|c|c|c|}
\hline Bo'g'in & Shenmu & Yunmu \\
\hline zai & $z$ & ai \\
\hline yao & $\mathbf{y}$ & ao \\
\hline kan & k & an \\
\hline
\end{tabular}

Xitoy tilida 420ga yaqin bo'g'in mavjud. So'z hosil qilish uchun shu bo'g'inlardan foydalaniladi. Xitoy tilida bitta bo'g'in bitta so'zni hosil qilishi mumkin. Masalan, 课-ke-dars, 人ren-odam, 学-xue-o'qimoq, 她-ta-u. O'zbek tilida ham bitta bo'g'indan bitta so'z hosil bo'ladi. Masalan, men, sen, $u$.

\begin{tabular}{|c|c|c|}
\hline Bo'g'in & Shenmu & Yunmu \\
\hline laoshi & l, sh & ao, i \\
\hline xuesheng & x, sh & ue, eng \\
\hline zhunbei & zh, b & en, ei \\
\hline yifu & y, f & i, u \\
\hline
\end{tabular}

Agar xitoy tilida so'z ikkita bo'g'indan tashkil topgan bo'lsa, bu so'zda ikkita shenmu va ikkita yunmu bo'ladi. Masalan, 宿舍-sushe-yotoqxona. Bu yerda $\boldsymbol{s u}$ bo'g'inida $\boldsymbol{s}$ shenmu $\boldsymbol{u}$ yunmu, she bo'g'inida sh shenmu $\boldsymbol{e}$ yunmu.

Xitoy tilida bo'g'inlar soni cheklanganligiga qaramay, so'zlar soni cheklanmagan. Chunki xitoy tilida omonimlik juda keng tarqalgan. Masalan, 是-shì-bo'lmoq va 事-shì-ish, 雨-yǔyog'moq va 语-yǔ-til. Misollardan ko'rinib turibdiki, so'zlarning pinyinda yozilishi va ohangi bir xil bo'lsa ham iyeroglifda yozilishi har xil. Iyerogliflar yordamida ularning har xil ma'no ifodalashini ko'rish mumkin. Yana ba'zi so'zlar bir xil talaffuz qilinsa ham ohang va iyeroglifning yozilish jihatidan bir-biridan farq qiladi. Masalan, 雪-xǔe-qor va 学-xué-o'qimoq, 和-hé-va bog'lovchisi va 掲-hē-ichmoq.

Xitoy tilida ohanglar muhim ahamiyatga ega. Ularni noto'g'ri qo'llash natijasida so'zlarning ma'nosi o’zgarib ketishi mumkin.[2,3] Masalan, 妈-mā-ona, 麻-má-arqon, 马 -măot, 骂-mà-urishmoq, 吗-ma-yuklama.

Ohang belgilarini besh ko'rinishi bo'lib, bu belgilar quyidagicha ko'rinishda bo'ladi:

Birinchi ohang shunday ko'rinishda bo'ladi: $\longrightarrow$. Bu ohang davomli ohang bo'lib, bir tekis davomli talaffuz qilinadi va uchinchi ohangga nisbatan qisqaroq talaffuz qilinadi. Misol: 八 [bā]-sakkiz.

Ikkinchi ohang shunday ko'rinishda bo'ladi: $>$. Mazkur ohang o'suvchi ohang hisoblanib, talaffuz vaqtida tovush keskin ko'tariladi. Ikkinchi ohang birinchiga nisbatan qisqa aytiladi.Misol: 拔[bá]-sug'urmoq.

Uchinchi ohang shunday ko'rinishda bo'ladi: Bunda talaffuz vaqtida tovush pasayadi va yana balandga ko'tariladi.Misol: 靶[bă]-nishon.

To'rtinchi ohang shunday ko'rinishda bo'ladi: \. Ushbu pasayuvchi ohang yuqori ohangdan boshlanib, oxirigacha keskin pasayadi. To'rtinchi ohang qisqa va tez tallaffuz qilinadi.Misol:爸[bà]-ota.

Beshinchi ohang urg'usiz ohang yoki erkin ohang. Alohida xususiyatga ega bo'lmagan,urg'usiz qisqa ohang. Misol: 吧[ba]-yuklama. 
Har doim ham xitoy tilidagi so'zlar va bo'g'inlar qabul qilingan pinyin asosida talaffuz qilinadi deb bo'lmaydi. Bunga misol qilib adabiy til va shanxay shevasini olish mumkin:

\begin{tabular}{|c|c|c|}
\hline & Adabiy til & Shanhay shevasi \\
\hline 4 & si & shi \\
\hline 10 & shi & si \\
\hline salom & ni hao & nong ho \\
\hline $\mathrm{u}$ & ta & yi \\
\hline
\end{tabular}

Foydalanilgan adabiyotlar

1. 刘旬。新浐用俉果本 1 。北京 2002 年。

2. 李数其・Boya Chinese I. 2004 年。

3. 姜荫苹HSK 1. 北京 2002 年。

4. www.ziyonet.uz

5. www.edu.uz

\section{XITOY TILIDA 把字句 NING IFODALANISHI}

Atamuradova Mavzuna Usmonovna Samarqand davlat chet tillar instituti talabasi Ilmiy rahbar: Zang Ying 蔵颖 E-mail: lady.atamuradova@gmail.com

把字句 (baziju) - Xitoy tilida fe'lli kesim va 把 yordamida to'ldiruvchi bilan birga qo'llaniladigan gaplar. Ulardan nutqda keng foydalaniladi.

把 gapda kesim ta'sir qilgan to'ldiruvchidan oldin qo'llaniladi. Xitoy tilida gap bo'laklarining joylashuvi quyidagi ketma- ketlikka asoslangan:

Subyekt + fe'l + obyekt

Ega + kesim + to'ldiruvchi

Masalan, 我看书。 - wo kan shu - Men kitobni o'qidim. Bu yerda 我- ega, 看- kesim, 书to'ldiruvchi.

Ammo 把 li gaplarda gap bo'laklari tartibi o'zgaradi. Ya'ni to'ldiruvchidan oldin 把 qo'yiladi va kesim to'ldiruvchidan keyinga o'tadi:[1,42]

Subyekt + 把 + obyekt + fe'l

Ega + 把 + to'ldiruvchi + kesim

Masalan, 你把电话号码记一下。 - ni ba dianhua hao ma ji yi xia. - Sen telefon raqamni eslab qolgin. Bu gapda 电话号- to'ldiruvchi vazifasini bajarmoqda.

把 ba'zan «olmoq» tarzida tarjima qilinadi:

我把词典放在桌子上了。- wo ba cidian fang zai zhuozi shang le.

Bu gapni so'zma so'z tarjima qilganda quyidagi ma'noni beradi: Men lug'atni olib stolning ustiga qo'ydim. Ammo badiiy tarjimada: Men lug'atni stolning ustiga qo'ydim.- ko'rinishida ifodalanadi.

把 aniq bir obyekt ustida bajarilgan jismoniy harakat oldidan ishlatiladi. Ammo ba'zan 把 qo'llanilgan gaplarda odatiy gap bo'laklari ketma- ketligi, subyekt $+f e^{\prime} l+$ obyekt ko'rinishi buzilganligi ta'kidlanadi. Lekin bunday hollarda 把 ning fe'l vazifasini ham bajara olishi hisobga olinmagan:

Subyekt + 把 (fe'l) + obyekt + boshqa fe'l

Ayrim hollarda 把 li va odatiy ko'rinishdagi gaplarni taqqoslaganda ular orasidagi farqni ko'rish mumkin:

老师把这个问题讲明白了。- laoshi ba zhege wenti jiang mingbai le. - O'qituvchi bu savolni tushuntirdi.

老师讲明白了这个问题。- laoshi jiang mingbai le zhege wenti.- O'qituvchi bu savolni tushuntirdi. 
Yuqoridagi misollardan ko'rinib turibdiki, 把 li gapda to'ldiruvchiga ya'ni «bu savol» so'ziga ta'kid ma'nosi tushgan. Odatiy ko'rinishdagi gapda esa ta'kid ma'nosi kuzatilmaydi. Ammo o'zbek tiliga bir xil tarjima qilinadi.

把 li gap konstruksiyasi boshqa konstruksiyalardan ustida amal bajariladigan obyektning aniq ekanligi bilan farq qiladi va quyidagi his- tuyg'uni ifodalovchi mavhum so'zlar oldidan qo'llanilmaydi:

爱 - ai- sevmoq, 喜欢 - xihuan - yoqtirmoq, 想念 - xiangnian - sog'inmoq, 了解- liaojie tushunmoq, 害怕 - haipa- qo'rqmoq, 痛恨 - tonghen- nafratlanmoq. 我把他想念 - wo ba ta xiangnian.

Ushbu misolda 把 xato qo'llangan. Gapning to'g'ri ko'rinishi esa quyidagicha ifodalanadi: 我想念他。- wo xiangnian ta. - Men uni sog'indim.

Biron kishidan biron bir narsani iltimos qilishda yoki biron kishiga buyruq berishda 把 li gapdan foydalaniladi:[3,93]

请你把衣服洗了。 - qing ni ba yifu xi le. - Iltimos kiyimlarni yuving.

你把灯关了吧。 - ni ba deng guan le ba. - Svetni o'chir.

把 li gaplarda inkor ma'noni ifodalash uchun 把 dan oldin inkor yuklamasi qo'llaniladi:[1,88]

你不要把我的果汁喝完。- ni buyao ba wo de guozhi he wan.- Sen menig sharbatimni oxirigacha ichma.

我不会把这件事告诉父母。- wo buhui ba zhejian shi gaosu fumu. - Men bu ish haqida ota-onamga ayta olmayman.

把 li gaplarda so'roq ma'noni quyidagi 3 ko'rinishda ifodalash mumkin:

1. So'roq yuklamasi yordamida 你可以把灯关了吗? - ni keyi deng guan le ma? - Sen svetni o'chira olasanmi?

2. So'roq so'z yordamida

你把我的书放在哪里了? - ni ba wo de shu fang zai na li le? - Sen mening kitobimni qayerga qo'yding?

3. Fe'lni inkor shaklda takrorlash yordamida

你能不能把电脑给我? - ni neng bu neng ba diannao gei wo? - Sen kompyuterni menga bera olasanmi?

Hisob so'z 把 dan keyin obyektdan oldin qo'llaniladi.[1,42]

他把十篇文章翻译好了。- ta ba shi pian wenzhang fanyi hao le. - U o'nta maqolani tarjima qildi.

Fe'lli hisob so'zlar 把 li gapning oxirida qo'llaniladi:

你把这部电影看两回。- ni ba zhe bu dianying kan liang hui. - Sen bu kinoni ikki marta ko'r.

1. 刘旬。新实用娪果本2。北京 2002 年。

\section{Foydalanilgan adabiyotlar}

2. 李老其・Boya Chinese II. 2004 年。

3. 姜亚HSK 3. 北京 2002 年。

4. www.ziyonet.uz

5. www.wikihsk.ru 


\section{GABRIEL GARSIA MARKESNING “YOLG'IZLIKNING YUZ YILI" ASARIDAGI METAFORIK VOSITALAR}

\section{Mirzahmedov Sirojiddin Rahmatulla o'g'li O'zbekiston davlat jahon tillari universiteti magistranti}

Annotation: In present work we are going to talk about the metaphoric elements in the "One hundred years of solitude" which is a landmark 1967 novel by Colombian author Gabriel García Márquez that tells the multi-generational story of the Buendía family, whose patriarch, José Arcadio Buendía, founded the town of Macondo, a fictitious town in the country of Colombia.

Metafora "Yolg'izlikning yuz yili" (Cien años de soledad) asarining asosiy tasvir

ifodasidir. Gabriel Garsia Markesning "Yolg'izlikning yuz yilligi" asari romanning metaforizatsiya nuqtai nazaridan muhim ahamiyatga ega. Nafaqat badiiy shaklning bezatilishi miqyosida balki, turli qit'alardagi adabiyotlarda umumiy estetik naqshni tasdiqlovchi dalil sifatida. Eng avvalo, metaforik boshlanish uning xususiyatlaridan biri bo'lgan aralash yoki birlashtirilgan shakllarning mahsuloti sifatida ham. U " Yolg'izlikning yuz yili " badiiy dunyosining bir biriga begona tarkibiy qismlari bilan inson tafakkuriga o'zaro ta'sir qiladi: afsona, hayotga o'xshash tasvir, an'anaviy epik hikoya, karnaval-o'yin elementi, kulgili kategoriya, "sehrli realizm", travestiya. Shu bilan birga, "Yolg'izlikning yuz yili " - Robb-Griye, Abe, Zyuskindning nasridan ko'ra o'zgacha metaforik tuzilmalar mavjud bo'lgan ishdir.

Gabriel Garsiya Markesning o'zi ta'kidlashicha, "Yolg'izlikning yuz yili"kitobini yaratar ekan, u olamshumul roman yaratishga intilgan. Romanning shakliga kelsak, bu muallif Gabriel Garsiya Markesning g'oyasini yuzaga chiqarish ustida ishlagani ko'zga tashlanadi,barcha turdagi metaforalaning chambarchas ko'rinishga kelgan holda uchrashi buning misolidir. Biroq, bu polinom metafora faqat "yadro"ga individual tasvirlarni tortib, butunlikni topganda ochiladi. Ular orasida ko'chma ma'noli so'zlarning aloqalarini o'rnatish orqali metaforik tasvir badiiy reallikka aylanadi. Gabriel Garsiya Markesning romani dunyosida ko'p turdagi metaforalar mavjud. Bunga "cho'chqa dumli avlod", uning tahdidiningpaydo bo'lishi va romanning so'nggida Buendia oilasiningtanazzulini belgilashi misol bo'la oladi. Makondo yerlarini vayron qilgan "Injil bo'roni g'azabi", "xotira yo'qotish kasalligi" va to'rt yil, o'n bir oy va ikki kun davom etgan Makondo yomg'iri bularga yaqqol misoldir. Ajnabiy Melkyadesning sirli pergamentlari- Buendia oilasining tarixi, uningkundalik tafsilotlari, hamda yuz yildan so'ng sodir bo'ladigan voqealarni hikoya qiluvchi manbaadir. Garchi bu tasvirlar mustaqil hayot kechiruvchi insonlarni tarixi kabi taassurot qoldirsa-da, ular metaforaning tashqi va ichki, umumiy qonunlariga bo'ysunadi va muallifning badiiy fikrlash mantig'i hukmronlik qiladigan monolitik butunlikni tashkil qiladi. Metaforaning tashqi rivojlanishi, tasvirlarning syujet bilan biriktirilishi Buendiyaning oilaviy xronikasi va Makondo shahrining tarixiga asoslangan. Bu shaharning asosi, yangi yerlarni qidirib kelgan Buendia shajarasi ajdodlari - Xose Arkadio va Ursula haqida. Doim ularni ta'qib etayotgan taqdir va uning cho'chqa dumi bilan tug'ilajak avlod davomchisi la'natini doimiy eslatib turishi (Ursula ongida har qanday holatda ham buni yod etilishi) -Buendia oilasi tarixining bu lahzalari, asarning boshlang'ich va yakuniy qismlarda, hikoya boshidan boshlab muallif tomonidan beriladi. Ularning asosida Buendia oilasining murakkab hayoti va olti avloddan iborat bo'lgan oila vakillarining hayotiy hikoyalari yotadi. Buendia taqdiri Makondo tarixidan ajralmas va unga chambarchas bog'liqdir. Qishloqning afsonaviy davridan boshlab, "dunyo hali juda yangi bo'lgan, ko'p narsalar nomga ega bo'lmagan va barmoq bilan ko'rsatilishi kerak bo'lgan", davrga qadar bu hikoya afsonaviy "xotira yo'qolishi" va "yomg'ir"voqealari orqali harakat qiladi. Va bir muncha vaqt o'tgach, tarixiy, "Banana kompaniyasi" Makondo shahrida majburiy o'yin-kulgi va jamoat uyi, stansiyada ish tashlash va ommaviy otishma bilan "sivilizatsiya" 
voqealarini o'z ichiga oladi, fuqarolik urushlari ham bundan mustasno emas. Bu afsonaviy tarixiy yo'l va Makondo qishlog'i "Injil bo'roni" tufayli yakun topadi, bu yer yuzidan va odamlarning xotirasidan "shaffof (yoki ruhiy) shahar" sifatida yo'q bo'lib ketadi. Gabriel Garsiya Markesning romanida "yolg'izlik" metaforik zanjirda o'zining metaforikligi va o'zo'zidan rivojlanishi tufayli badiiy o'ziga xoslik, majoziy materializm va dizaynga egadir. Hikoyaning barcha ko'p ma'nolarini o'z ichiga olgan yolg'izlik metaforasi umummilliy (Kolumbiya va lotin Amerikasi) va butun insoniy ramz bo'lib, universalizatsiya qilinadi; "Yolg'izlikning yuz yili" romani dunyosida u muallif nigohining metaforasiga aylanadi. Aytish mumkinki, "Yolg'izlikning yuz yili" metaforik tuzilish jihatdan takrorlash usuli ustunligini hatto, universalizatsiya darajasida ekanligini aytish mumkin. U nafaqat romanda birlikning asosiy modellashtirish prinsipi, balki hayotiy polifoniya va ambivalentlikni simfonik badiiy butunlikka aylantiradi va o'zgartiradi. Ushbu texnikaning dialektik harakatchanligi estetikva axloqiy jihatdan mavjud bo'lgan haqiqatga aylanganda, estetikaning axloqiy jihatdan o'sib borishiga ta'sir qiladi, bu ham o'quvchining estetik va romantik tuyg'usiga murojaat qiladi. Axir, "Yolg'izlikning yuz yili " romanida Gabriel Garsiya Markesning amalga oshirilgan tasvir har xil ramziy va metaforik takrorlanishlarda hayotning axloqiy va falsafiy sohasini qamrab oladi. Yolg'izlik - barcha Buendiya avlodlarining yagona taqdiridir, xarakter, hayotiy energiya yoki passivlikdan, ijtimoiy tadbirlarda yoki individualizmda ishtirok etish, bu turning gullabyashnashi va pasayish vaqtidan qat'i nazar, ular yolg'izlikka mahkumdir. Kashtanga bog'langan, dunyodan ajralib qolgan, Buendia oilasining asoschisi - Xose Arkadio ham yolg'izlikda vafot etadi.

Roman Lotin Amerikasi adabiy portlashi natijasida yuzaga kelgan avlod vakilining eng oldi asari hisoblanadi. Unda g'ayrioddiy va kutilmagan voqealar shunday bayon etilganki, na hikoyachi, na personajlar bu voqealardan ajablanadi. Bu asar dunyosida mo'jizalar o'zini xuddi har kungi reallikday, hech qanday tushuntirish talab qilmaydiganday tutadi. $\mathrm{Bu}$, albatta, adabiyotda qoida buzilishi. Lekin kim bilsin, balki bu Dekart falsafasidagi fikrlashning karteziancha, ortidan dualizmni ergashtiruvchi tartibidir...

Asarda keladigan har bir voqea, tarixiy vaqtni ilg'agan holda, xotirada tizilish va unutilishni o'z ichiga oladi. Muallif o'z yurti Kolumbiyaga xos voqeliklarni o'ylab topilgan Makondo shahri misolida ko'rsatadi. Balki butun Lotin Amerikasini nazarda tutgandir. Makondo - shunchaki so'z emas, bu go'yo o'z shoxlari bilan har xil sirlarni, afsonalarni, orzu va qayg'ularni yashirgan, vaqt ta'sirida unutilishga mahkum bo'lgan oilaviy daraxt timsolidir. Buendia oilasining ichki tarixi bir vaqtning o'zida Garsiya Markesning bolaligi hamdir.

O’z yurti Arakatake qishlog'iga safar xotiralarida muallif XIX asrda liberallar va konservatorlar o'rtasidagi kelishmovchiliklar, ilk poyezd kelishi, banan vasvasasining kuchayishi, kapitalizm ekspansiyasi va mutloq hokimlikni keltirib o'tgan. Asarda juda ko'p kuchli shaxslar namoyon bo'ladi. Lekin bu kuchlar, bu qudrat vaqt oqimiga qarshi nima qila oldi? Tabiatga qarshi nima karomat ko'rsata oldi? Inson taqdiriga qarshi nima qila oldi? Hech narsa. Asarning hamma qahramonlari qalban yoki jismonan yolg'iz edi. Sulola asoschisi daraxtga bog'lanib, umrining so'nggi kunlarini yolg'iz o'tkazgan bo'lsa, sulolaning oxirgi vakili chaqaloq ham yolg'izlikda o'lim topdi.

\section{Адабиётлар:}

1. Gabriel Garsia Markes, Yolg'izlikning yuz yili, - Toshkent: Sharq, 2010

2. Фирсова Наталия Михайловна, Грамматическая стилистика современного испанского языка, - Москва: Ленанд, 2019

3. Хованская 3.И. Стилистика испанского языка, 2011.

4. Апресян Ю.Д. Языковая аномалия // Филологические исследования. - М.-Л.: Наука, 2009. c.51-52

5. Арутюнова Н.Д. Языковая метафора. Синтаксис и лексика // Лингвистика и поэтика. - М.: Наука, 2007. - с.147-173.

6. Real Academia Española (2014): Diccionario de la Lengua Española. Madrid: Espasa-Calpe. Vigésima edición. 


\section{LOS PRÉSTAMOS LINGÜÍSTICOS EN LA LENGUA ESPAÑOLA}

\section{Mirzahmedov Sirojiddin Rahmatulla o'g'li \\ O'zbekiston davlat jahon tillari universiteti magistranti}

Annotation: Aloanword (also loan word or loan-word) is a word adopted from one language (the donor language) and incorporated into another language without translation. This is in contrast to cognates, which are words in two or more languages that are similar because they share an etymological origin, and calques, which involve translation.
Key words : extranjerismo, procedencia, monolingüe, barbarismo, marginal, recurrente, unilingüismo, sincrónicamente, manifiesta, germanismos

El concepto de préstamo o extranjerismo se halla ya en el primer diccionario monolingüe con el que cuenta nuestra lengua: El Tesoro de la lengua castellana o española de Sebastián de Covarrubias. Ahora bien, como era de esperar, Covarrubias, por supuesto, registra la palabra préstamo pero no en el sentido de palabra importada, y la palabra extranjerismo ni siquiera la recoge. Sin embargo, ofrece una serie de palabras que él mismo califica de extranjerismos, distinguiéndolas así de aquellas que aún procediendo del griego, latín o incluso árabe, no las considera extranjeras, con lo que quizá, probablemente de manera inconsciente, está diferenciando los préstamos integrados, sea cual sea su procedencia, de los extranjerismos o xenismos, tal como los concebimos hoy en día. De ahí, pues, que para hacer un análisis de la situación actual del préstamo lingüístico creamos oportuno arrancar del tratamiento y consideración que del mismo se ofrece en dicho diccionario.

Hay una serie de dificultades a la hora de delimitar el concepto de préstamo que encuentran su raíz, como ha indicado Bermúdez Fernández, en dos tipos de cuestiones: la diversidad de enfoques básicos desde los que se define1 y la relación dialéctica que dicho concepto establece con otros conceptos del sistema nocional de la transferencia, como pueden ser "xenismo", "extranjerismo" y "barbarismo". Pero veamos algunas de las propuestas más representativas.

El préstamo lingüísticoen un sentido estricto, el préstamo consiste, según la caracterización de Josette Rey-Debove, en un proceso mediante el cual una lengua cuyo léxico es finito y fijo en un momento dado toma de otra lengua (cuyo léxico es también finito y fijo en un momento dado) una voz (en su forma y contenido) que no poseía antes.

Los préstamos léxicos constituyen el fenómeno más recurrente asociado al contacto lingüístico.Este último se produce necesariamente a raíz del contacto entre culturas, es decir no hay penetración lingüística sin penetración cultural. La condición social del hombre lo lleva a buscar comunicarse con el otro pertenezca o no a su comunidad idiomática generándose interrelaciones entre los pueblos. Siendo el lenguaje un objeto cultural, todo intercambio en el ámbito de la cultura implica un intercambio lingüístico. Las situaciones de contacto de códigos no son, por lo tanto, marginales. Por el contrario, es sabido que la mayor parte de las comunidades son multilingües y no se ha constatado la existencia del unilingüismo en ningún lugar del mundo. Consecuentemente no sólo no se conoce ninguna lengua pura, que no contenga en su interior alguna palabra de origen extranjero.

Existen dos tipos de factores que inciden, ya sea positiva o negativamente, en el contacto entre lenguas. Dichos factores pueden ser externos (psicológicos y sociales) o internos (estructurales, lingüísticos). Entre los factores externos, destaca la existencia o inexistencia de una actitud de rechazo a los préstamos por parte de la comunidad de hablantes.

A juzgar por la bibliografía existente, no han sido muchas las ocasiones en que se han planteado asuntos relacionados con los denominados extranjerismos en la clase de español como lengua extranjera, ya sea porque no se considera una cuestión que entrañe suficiente 
interés o porque al hacerlo podrían aparecer nuevos problemas que se sumarían a la ya compleja labor docente: téngase en cuenta que en estos casos el estudiante extranjero ha de aprender una unidad extranjera a través de un sistema lingüístico que también es extranjero. Pero la dificultad no sería tanta si damos al extranjerismo su justo valor: «voz, frase o giro que un idioma toma de otro extranjero» (así lo define el DRAE): sería, pues, extranjerismo lo foráneo sincrónicamente arraigado, y no cualquier elemento de otra lengua que se presente de forma repentina y excepcional. El extranjerismo es, por tanto, una unidad integrada en el idioma, aunque a veces puede presentar caracteres formales que delatan su procedencia.

Para conocer la importancia del elemento árabe en la formación y desarrollo de la lengua española, es preciso analizar la relación lingüística entre ambos sistemas y establecer el lugar que ocupa el árabe en el ámbito general de la historia de la lengua española.

El concepto de germanismo en sentido estricto presenta características similares al de anglicismo, con la salvedad de que la lengua original del préstamo en este caso es el alemán. Desde este punto de vista, estamos de nuevo ante un fenómeno que se manifiesta a cualquier nivel lingüístico, por lo que se hace necesario reducir el ámbito del análisis únicamente al nivel léxico.

El castellano es una de las lenguas románicas surgidas del latín. Al inicio no debió de ser más que una de las variantes dialectales que esa lengua importada adquirió en ciertas zonas y entre ciertos hablantes de la Península Ibérica. Más tarde, la lengua castellana se desarrolló hasta llegar a ser una entidad lingüística suficientemente diferenciada con sus rasgos propios. Al lado de estos tres aspectos, existen muchas otras propiedades del castellano que subrayan el vínculo con la lengua latina, más particularmente en el léxico como atestigua la presencia de latinismos en castellano moderno. Es en este tema que profundizaremos en el presente estudio. La estructura de la presente obra consta de dos partes principales: una primera parte que definirá el concepto de latinismo en general, y una segunda parte que versará sobre el problema particular de la pluralización de los latinismos en la lengua española.

En primer lugar, se aclarará brevemente la evolución del latín al castellano y el vínculo estrecho entre ambas lenguas. Después, en segundo lugar, se hablará del conflicto terminológico que existe entre el término cultismo y el término latinismo. En este apartado, se discutirá las distintas opiniones de varios lingüistas en cuanto a este problema terminológico, seguido por una breve conclusión que comunicará qué término se utilizará en esta obra y por qué.

En el estudio teórico, tras haber estudiado el sistema del plural en latín y en castellano, describiremos más detalladamente la formación del plural de los latinismos en castellano. Según la Real Academia Española (RAE), los latinismos hacen el plural en -s, en -es o quedan invariables dependiendo de sus características formales, como ocurre con el resto de los préstamos de otros idiomas. Después, por medio de un estudio de corpus, trataremos de averiguar si la teoría corresponde a la práctica. Investigaremos la formación del plural de algunos latinismos utilizados habitualmente en español moderno. Los subdividiremos en tres clases morfológicas: los latinismos acabados en -m (currículum, memorándum, referéndum, ultimátum, auditórium, desiderátum, álbum y ítem), los latinismos acabados en -s o -x (campus, estatus, corpus, ómnibus, cactus y eucaliptus), y los latinismos acabados en -t (déficit, accésit, superávit y hábitat).

\section{Адабиётлар :}

1. Alvar Ezquerra, M. (2003): La Formación de Palabras en Español. Madrid: Arco/Libros.

2. Bermúdez Fernández, J. M. (2007): El Préstamo Lingüístico en Español Peninsular Actual: Tratamiento Teórico y Análisis de Datos, Tesis doctoral de la Universidad de Málaga (inédita).

3. Covarrubias Sebastián de, Madrid, M. DC. XI. El Tesoro de la lengua castellana

4. Diccionario de la Real Academia Española, Madrid, 2005.

5. Josette Rey-Debove, Paris, Francia, 1998. La linguistique du signe. 


\section{L'INFLUENCE DES FRANCOPHONES SUR L'ENRICHISSEMENT DE LA LANGUE FRANÇAISE}

\section{To'rayeva Maftuna Akbar qizi Samarqand davlat chet tillar instituti magistr talabasi E-mail: maftunaturayeva18@gmail.com}

Annotation: The article deals with the analysis of neologisms through contributions from the most active Francophone countries. As the subject of research, we take words that appeared in the Larousse and Petit Robert dictionaries, in three editions from 2017 to 2019, which are often used by the French.

\author{
Key words : \\ neologism, standard French, \\ Canadian French, Quebec French, \\ Belgian French, Swiss French, loan \\ word, French speakers
}

Le français est l'une des langues officielles de l'Union Européenne. Dans le monde, plus de 80 millions de personnes ont le français comme langue maternelle, tandis qu'environ 190 millions le parlent en tant que seconde langue [1] Au total, il y a 270 millions francophones qui représente différentes variétés de langue française. Selon les linguistes, il y a des idiomes principaux comme le français standard, le français canadien ou français québécois, français belge et français de Suisse.

Il y a une grammaire standard utilisée par les francophones, mais leurs prononciations et leurs lexicographies diffèrent. Le vocabulaire traditionnel d'une langue s'enrichit de néologismes, c'est à dire de mots de sens nouveau et de locutions nouvellement créées. L`introduction du nouveau mot dans la langue peut être opérée par un emprunt à une autre langue ou par un processus de fabrication de nouvelles unités lexicales.

L'emprunt à une langue étrangère est l'un des processus les plus importants d'enrichissement lexical de la langue. Le français emprunte des termes à des langues étrangères, surtout à la fin du XX ème siècle et au début du XXI ème siècle, le nombre de mots empruntés augmente plus rapidement.

Le français des francophones hors de France exerce-t-il une influence sur le français?

Chaque année, le Larousse et le Robert incluent les mots nouveaux parmi lesquels on trouve les mots issus de la francophonie. Comme la directrice du Département des dictionnaires chez Larousse, Carine Girac-Marinier, explique le processus de la naissance des mots nouveaux chez Larousse, on fait la liste des néologismes clairs et fréquents, parmi lesquels on choisit les termes en déterminant les plus actuels.

Le 22 mars 2019, le journaliste du journal le Monde, William Audureau a publié un article intitulé « D’où viennent les nouveaux mots de la langue française? » [2] où il a montré la répartition des nouveaux mots du français par type d'origine. Pour son analyse, il s'en tient à une liste de 410 mots apparus dans les dictionnaires Larousse et petit Robert, dans les trois éditions de 2017 à 2019 . Selon cette répartition, la part des pays francophones sauf la France est de 14,6\%. En utilisant cette liste, on fait l'analyse des apports des pays les plus actifs de la francophonie, et les mots utilisés souvent par les Français.

On peut noter que le rôle de la langue québécoise (on dit encore le français canadien, le français du Québec, le québécisme) augmente d'un jour à l'autre. Plus de 25 mots québécois ont été inclus dans les dictionnaires français en trois ans. L'office québécois s'efforce de réduire la place des emprunts (notamment à l'anglais) pour, en revanche, augmenter le nombre des calques en langue française ou la formation de nouveaux mots. Il y a des mots comme «le balado», «téléverser», «infolettre», «la partisanerie» qui ont été calqués par l'office québécois pour traduire en langue française des mots anglais et italiens "podcast», «to upload », «newsletter », " partigianeria ». " La douillette », « le préfet», " plate » sont des mots français, qui prennent leur sens du Québec. C'est à dire qu'ils sont des calques 
sémantiques enrichissant des sens figurés des mots français. Par exemple, la douillette signifie en français la couette, bourrée de duvet.

Les termes québécois comme "dézipper», "zipper», sont calqués sur la structure grammaticale de l'anglais à qui ils les ont empruntés. On peut expliquer cette structure par la conservation de la racine d'emprunt, à laquelle on ajoute des morphèmes issus du français. Ces verbes sont empruntés à l'anglais "to zip": fermer (la fermeture éclair).

Il y a encore des termes québécois qui désignent des réalités endogènes (culturelles)[3] comme "caribou», " orignal» ou autre et des termes scientifiques comme "carboneutre», « écocentre », "hydrangée », « inhalothérapie », " relationniste »; le terme de gastronomie «pet-de-sœur»; l'acronyme «VPS» (Virtual Private Server- « serveur privé virtuel ») ; le mot familier « gougounes ». Nonobstant les différences entre les lieux et les cultures, le québécisme, notamment l'Office québécois de la langue française (OQLF), entraîne l'enrichissement et le développement de la langue française.

Le français parlé en Belgique (le français belge, le belgicisme) est plus proche du français parlé en France que de celui parlé au Québec. Un grand nombre de belgicismes sont employés dans le Nord de la France à cause de la proximité culturelle et des échanges transfrontaliers.[4] Bien que les habitants francophones de Belgique n'aient aucune difficulté à comprendre le français standard, il y a des certaines nuances linguistico-culturelles: des termes qui sont d'abord utilisés seulement en Belgique et ensuite diffusés en France. Le belgisme a aussi son apport: sur ces trois années (2017-2019), on a ajouté 11 néologismes: «bisseur», « dégagisme », « dix-heures », « exemplatif », « gouttiner », « ket », « toquer », « grigneux/euse », "quatre-heures», "réfectionner», «zythologue». Le belgicisme "dix-heures» signifie une collation mangée vers dix heures, souvent par les enfants lors de la récréation, et le « quatreheures » signifie la collation prise au milieu de l'après-midi. Ce terme s'entend comme synonyme familier du mot goûter. L'emprunt «zythologue » s'utilise pour désigner un expert en bières. Il y avait le nom "réfection » en français, mais c'est les Belges qui ont créé le verbe « réfectionner ». En français il y a l'adjectif « exemplaire» qui qualifie une connotation morale, mais le néologisme « exemplatif» signifie donner à titre d'exemple.

Par ces apports, lefrançais de Suisse (ou suisse romand) se place après le québécisme et le belgisme. On a ajouté les mots nouveaux "aguiller», "azorer», " biscôme », " calure », " cramine », "ébriquer». En analysant des néologismes interprétés de Suisse, on peut voir la cohabitation linguistique de l'allemand et l'influence de l'ancien français. Par exemple, l'étymologie du terme « aguiller » est de l'ancien français. L'origine du mot « ébriquer » est du germanique «brechen ».

La plupart des mots empruntés de l'Afrique francophone provient des réalités endogènes(culturelles, climatiques, toponymiques), comme des mots «le haoussa», «la fatiha », «le fourou », " bisser», « bidonvillois/e ». Le haoussa est une langue tchadique, parlée en Afrique occidentale. La fatiha est une cérémonie de musulmans, qui aura lieu avant la noce. Selon le Larousse, en Afrique centrale, on utilise le mot «fourou » pour désigner un insecte transmettant des maladies. Puisqu'il y a beaucoup de relations interculturelles, d'immigration, on fait du mélange de cultures, coutumes, mode de vie, gastronomie, bien évidemment ce processus fait emprunter des mots de l'autre culture.

Il existe des néologismes qui s'emploient dans différents domaines de différents pays francophones et des mots nouveaux qui ont le même sens, mais ils diffèrent dans l'écriture et la prononciation. En France et en Belgique le verbe "bisser» est le terme de l'éducation «redoubler» un niveau de classe, alors qu'en République Centrafricaine, on "redouble" l'invitation d'une dame à danser. Donc ce processus révèle les différents signifiés d'un même mot, et enrichit les domaines de l'utilisation. Au Maroc, la personne qui sait lire et écrire se dit « l'alphabète », pourtant pour les Français c'est étonnant, ils utilisent ce terme pour le Marocain qui peut lire et écrire. En France « le préfet » est un représentant de l'État dans le département; en Suisse, le magistrat qui représente le gouvernement cantonal dans un district ; en Belgique, 
le directeur d'un athénée ou d'un lycée ; au Québec, le premier magistrat d'une municipalité régionale de comté, désigné ou élu au suffrage universel; au Cameroun, le fonctionnaire nommé par le président de la République pour diriger chaque département. Donc, en français le préfet est un fonctionnaire de l'État, mais sa fonction est différente dans chaque pays francophone.

Si lefrançais standard emploie beaucoup les verbes auxiliaires pour la verbalisation comme «faire des courses», le français d'Afrique applique la suffixation comme « cadeauter »(cadoter) et « cadonner »(cadeauner) qui exprime « offrir en cadeau ».

XXIème siècle est une ère de l'information dans laquelle les relations internationales se sont développées et des conflits ont éclaté en même temps, de même que le mélange des nations et des cultures enrichit simultanément la culture et détruit l'appartenance ethnoculturelle. A l'influence de la culturalisation et de la civilisation, la langue emprunte des mots.

Donc les mots s'empruntent en appliquant certaines modifications phonétiques, ou pour adhérer au modèle morphologique du français. On peut cependant emprunter sans opérer aucune modification. Ce sont plutôt les gens qui prennent les mots et les emploient dans leur usage, mais les linguistes essayent de calquer et les transformer pour sauver l'originalité de la langue. Pendant que les français protègent le français de l'anglicisme, au fond de la langue, il change en raison de la francophonie et des relations interculturelles.

\section{Bibliographie :}

1. https://blog.lingoda.com/fr/differences-francais-quebecois

2. https://www.lemonde.fr/les-decodeurs/article/2019/03/22/d-ou-viennent-les-nouveaux-motsde-la-langue-francaise_5439961_4355770.html

3. http://observatoire.francophonie.org/diversite-linguistique/le-francais-comme-on-le-parle-entrevariete-emprunt-et-innovation/

4. https://fr.wikipedia.org/wiki/Fran\%C3\%A7ais de Belgique\#Le lexique : les belgicismes

5. Guilbert L. Théorie du néologisme. In: Cahiers de l'Association internationale des études francaises, 1973, n²5. P. 23.

6. Sablayrolles S. J-F. La Néologie en français contemporain. Honoré-Champion, -Paris : 2000, P. 195

\section{LEXIQUE DE L'ARCHITECTURE DES MONUMENTS HISTORIQUES}

\section{Abdumurodova Makhfuza Dilmurodovna Master de l'institut des langues étrangères de Samarcande E-mail : abdumurodovam@gmail.com}

Annotation: In this article it's described the lexicon of the terminology of the architecture of historic monuments in order to enrich the richness of the words of the representatives of tourism, especially guides-interpreters. The words are given with their explanations and in order of the alphabet as in dictionary. We can say that this article is a small thematic dictionary of the lexicon of architecture.
Key words : development of tourism, representatives of the organization of the trip, linguistic skills of specialists in field of tourism, duty of linguists, thematic dictionary, lexicon of the architecture of monuments, watertight, frame, architecture buttress, lintel, architecture portico etc.

Actuellement en Ouzbékistan le dévéloppement du tourisme apporte de plus en plus des emplois pour les réprésantants de la sphère du tourisme, comme les guides, les interprètes, les turopérateurs, les managers des hôtels etc. Mais parmi eux, c'est le guide qui parle plus que les autres, avec les voyageurs. Donc, il y a toujours des exigences pour les guides par rapport leurs connaissances sur l'histoire, archéologie, architecture, musées et bien sûr que leurs lexiques, leurs richesses des mots. La parole de guide doit être très claire et correcte, en tant qu'il est dans la mission de montrer le «visage » de son peuple. Améliorer et augmenter la capacité 
linguistique des spécialistes du domaine du tourisme, c'est à la charge des linguistes qui peuvent les aider avec les dictionnaires thématiques.

Dans les textes qui reflétent les informations des monuments historiques nous pouvons rencontrer souvent la términologie de l'architecture. Pour cela on a decidé de composer une liste du lexique des mots de l'architecture. On la présente en ordre de l'alphabet :

Béton - armé, précontraint, brut de décoffrage - le béton, mélange de ciment (à base d'argile et de calcaire) ou de chaux, de sable, de gravillons et d'eau a été utilisé à l'époque romaine (mais pas au Moyen Age). Le béton résistant bien à la compression, mais fragile en extension, on a imaginé plusieurs procédés pour le renforcer - le béton armé est coulé autour d'une armature en acier. Le béton précontraint, inventé en 1928 par Freyssinet, est un procédé qui permet au béton d'être plus fin et plus léger - en effet on introduit par des câbles une précontrainte qui agit en sens opposé à la contrainte prévue. Le coffrage du béton est l'utilisation d'une sorte de charpente métallique qui moule et maintient le béton que l'on coule ; le béton brut de décoffrage n'a été ni poli ni peint.

Chapiteau - partie élargie qui couronne une colonne (le mot vient d'ailleurs de caput, "tête", "sommet"). Sa décoration permet de reconnaître les ordres architecturaux.

Châssis - encadrement d'une porte ou d'une fenêtre.

Cintre (plein) - (du latin cinctura, ceinture) arcade dont la courbure est un demicercle (et non un arc brisé/ogive).

Cintré - de forme arrondie, en arc de cercle.

Claire-voie - clôture percée de "jour", de vide.

Claustra (un) - cloison légère, de faible hauteur, souvent ajourée.

Contrefort - c'est un renforcement du mur, épais et carré.

Corniche - partie saillante qui couronne un bâtiment, destinée à le protéger de la pluie.

Coursive - signifiant initialement un couloir étroit à l'intérieur d'un navire, une coursive désigne tout cheminement en hauteur bordant ou croisant un immeuble.

Éclectisme - empruntant aux diverses traditions architecturales sans en inventer de nouvelles. Caractéristique du $19 \mathrm{e} \mathrm{s}$, l'éclectisme fut rejeté violemment par le mouvement moderne.

Fonctionnalisme, fonctionnel - principe d'architecture de la fin du 19è s affirmant que "la forme suit toujours la fonction : telle est la loi" (Sullivan, architecte américain). C'est à dire que la diversité des formes n'est pas gratuite, mais exprime les différentes fonctions d'un bâtiment. A l'école du Bauhaus, les bâtiments sont découpés en blocs monofonctionnels distincts. Aux Etats Unis, à la suite de Taylor, la forme architecturale est censée découler des découpages internes d'un usage rationalisé de manière abstraite. Aujourd'hui, l'architecture fonctionnelle s'est imposée partout, conduisant d'ailleurs à son dépassement: certains bâtiments se veulent neutres par rapport à l'usage, permettant théoriquement toutes les utilisations (par exemple le centre Beaubourg).

Fronton - couronnement d'un édifice de forme triangulaire ou courbe.

Gardecorps - parapet pour empêcher de tomber.

Linteau - pièce horizontale, en bois, pierre ou métal, qui ferme la partie supérieure d'une porte ou d'une fenêtre et soutient la construction.

Loggia - balcon couvert, comme une petite loge.

Moulures - ornement allongé, en relief ou en creux. La modénature est le profil d'une moulure.

Mouvement moderne - l'architecture moderne se caractérise par la rupture avec le passé, notamment avec le néoclassicisme et l'éclectisme du $19^{\mathrm{e}} \mathrm{s}$. par l'utilisation des matériaux nouveaux, béton et acier, qui permettent la conquête de la hauteur, par l'aménagement de "plateaux libres", c'est à dire un espace intérieur libre de tout cloisonnement, par l'utilisation d'un nouveau vocabulaire architectural que Le Corbusier a exprimé par 5 principes: toitterrasse, pilotis qui libèrent le sol pour la circulation et la végétation, fenêtres en longueur 
ou "en bandeau", façade rideau et plateaux libres par ses liens étroits avec l'industrie, qui fournit des éléments préfabriqués, standardisés par son idéal de pureté, sa volonté de créer uniquement des volumes et des formes - d'où son rejet de l'ornement, l'utilisation de matériaux bruts, sans revêtement.

Murrideau ou façade rideau - façade librement dessinée sans poutre ni piliers extérieurs.

Ordre - système de formes et de proportions qui définissent un style architectural. La colonne est l'élément le plus important car elle définit les proportions générales (rapport entre la hauteur et la largeur, définie par le demidiamètre de la colonne, ou module). On reconnaît l'ordre par la forme des chapiteaux. L'Antiquité grecque a connu trois ordres : Ordre dorique c'est l'ordre le plus ancien, le plus simple, le plus "masculin". La colonne, massive, n'a pas de base, le chapiteau est lisse et simple. Ordre ionique - la colonne est plus élancée, le chapiteau est décoré de volutes en forme de cornes de bélier qui évoquent des cheveux féminins. Ordre corinthien - diffusé à l'époque hellénistique (de la mort d'Alexandre à la conquête romaine), et repris abondamment par les Romains, il est une variété plus ornée de l'ordre ionique. On le reconnaît facilement grâce aux feuilles d'acanthe de son chapiteau. Ordre colossal - cet ordre créé au 16è siècle est caractérisé par une grande hauteur des colonnes (ou des pilastres), qui correspondent à deux étages. Au dessus de la corniche se trouve un attique. L'ordre colossal a été utilisé par Palladio, par les architectes de Chantilly, d'Ecouen. A Paris, il est visible sur la colonnade du Louvre et sur les palais de Gabriel place de la Concorde.

Péristyle - colonnade entourant la cour intérieure d'un édifice, ou disposée autour d'un bâtiment (exemple sur la façade de l' Assemblée nationale, de la Madeleine).

Pignon - sommet triangulaire du mur situé sous le toit pentu d'une maison.

Pilastre - pilier ou colonne plate engagée dans un mur et formant une légère saillie.

Plateaux libres - espace intérieur que les habitants ou les employés peuvent aménager à leur guise, grâce aux structures modernes de béton qui évitent les murs porteurs.

Portique - galerie ouverte soutenue par deux rangées de colonnes, ou par un mur et une rangée de colonnes. Par extension, le terme désigne aussi une poutre horizontale soutenue à ses extrémités par deux poteaux verticaux.

Travée - portion de voûte, de pont etc. comprise entre deux points d'appui comme des colonnes ou des piliers.

Vantaux (vantail au singulier) - panneaux mobiles, dans une fenêtre ou une porte.

Voila une bonne dictionnaire thématique de la términologie de l'architecture des monuments historiques. Dans la parole il est mieux d'utiliser toujours avec leurs explications, si non ils pourront être incompréhensibles pour les voyageurs. Dans la conclusion, on peut dire que la capacité linguistiques et des lexiques des répresantants du tourisme doit être toujours en voie de développement.

\section{Litératures :}

1. Bayram Balci, Khoudaïkoul Ibraguimov: Dictionnaire Ouzbek - Français // Langues \& Mondes , L'Asiathèque -2001.

2. Cerge Eric Bon : Dictionnaire du Génie civil, de l'architecture \& de la construction // 2ème édition. 2017

3. Dictionnaire Poche Larousse : 76000 définitions, noms communs, noms propres // Nouvelle édition - LAROUSSE, la RÉFÉRENCE - 2020.

4. Ibragimov X., Mamadaliyev A., Mansurov U. Fransuzcha - o'zbekcha lug'at // "Nihol" nashriyoti, Toshkent - 2008. 


\section{L'IMPORTANCE DES STÉRÉOTYPES FRANÇAIS DANS LA COMMUNICATION INTERCULTURELLE}

\section{Abdumurodova Makhfuza Dilmurodovna Master de l'institut des langues étrangères de Samarcande \\ E-mail : abdumurodovam@gmail.com \\ Key words : development of tourism, representatives of the organization of the trip, linguistic skills of specialists in field of tourism, duty of linguists, thematic dictionary, lexicon of the architecture of monuments, watertight, frame, architecture buttress, lintel, architecture portico etc.}

Annotation: In this article it's described the lexicon of the terminology of the architecture of historic monuments in order to enrich the richness of the words of the representatives of tourism, especially guides-interpreters. The words are given with their explanations and in order of the alphabet as in dictionary. We can say that this article is a small thematic dictionary of the lexicon of architecture.

Annotation: This article describes the French stereotypes which reflect the general characteristics of the French people. The importance of these stereotypes in intercultural communication is described separately. Some examples of stereotypes of French culture are given, such as punctuality, frankness, complicity, disliking questions concerning private life, etc.

Key words: ethnic group, people representing another culture, ethnoculture, stereotypical imaginations, linguistic and cultural Universe, conceptual and mental image, stereotype, social stereotypes, communication stereotypes, mental stereotypes, cultural stereotypes, ethnocultural stereotypes, stereotypes of French people, punctuality, frankness, complicity, intercultural communication, importance of the stereotypes.

Chaque nation à sa manière divise le monde, possède sa propre façon de le conceptualiser. Chaque groupe ethnique a leurs propres idées sur le monde, sur les représantants d'une autre culture. Une personne perçoit et reproduit le monde sous la forme de normes définies par son ethnoculture, ne réalisant généralement pas de cela. La compréhension de ces normes et valeurs se produit dans le processus de la communication avec d'autres porteurs de leur propres discours qui reflètent leur culture. Dans chaque société des imaginations stéréotypées apparaissent - en ce qui concerne les comportements et les traditions au sein de leur espace culturel et également en ce qui concerne les représentants d'une autre étendue linguistique et culturelle.

Stéréotype - c'est un image conceptuelle du monde, une "image » mentale, une idée culturelle et nationale stable d'un groupe ethnique ou société et la particularité d'une langue et réflexion des représantants de divers cultures [5, 69].

Il se constitue des connaissances charactéristiques ou les comportements typiques des membres d'un groupe social et se base sur une simplification ou une image réductrice. Il est est une forme particulière de perception du monde qui se reflète sur les données de nos sens avant que ces données n'atteignent notre conscience $[4,92]$.

Le phénomène de stéréotype est appris non seulement par les linguistes, mais aussi par les sociologues, etnographes, cognitologues, psychologues et ethnopsycholinguistes. C'est pour ça il y a des types de stéréotype, comme les stéréotypes sociaux, les stéréotypes de la communication, les stéréotypes mentaux, les stéréotypes culturels, les stéréotypes ethnoculturels etc.

Le premier stéréotype des Français - c'est la ponctualité. Les Français sont connus par leur ponctualité dans la plupart des occasions. Ils arrivent au travail toujours à l'heure. Ce comportement est soutenu par la ponctualité des transports en commun. Normalement, le retard ne dépasse que des secondes, non au-delà des minutes. Mais dans le cas de diner, les Français tardent leur arrivée environ un quart d'heure pour que la famille qui invite puisse préparer le repas sans se dépêcher. C'est une exception au nom de la politesse. Cependant, c'est 
difficile pour les Ouzbeks d'être toujours à l'heure en raison des embouteillages ou de la perturbation des transports. Ces conditions peuvent évoquer d'autres retards, comme le commencement d'un évènement par exemple.

Le deuxième, c'est dire la vérité franchement. Lors qu'il y a un problème et il y a quelque chose qui ne va pas, généralement, les Français le disent franchement. Par contre, les Ouzbeks, ils ne peuvent pas dire quelque chose franchement. S'il y a quelque chose qui ne va pas, ils ont l'habitude de ne pas dire la vérité et d'accepter. C'est liée bien sûr avec leur mentalité. Par exemple, dans la vie professionnelle, si notre travail n'est pas bon, les Français le disent directement. Et aussi dans la vie quotidienne, s'ils n'aiment pas les choses que nous faisons, ils ne cachent pas leur mécontentement car eux, ils valorisent beaucoup l'honnêteté.

Le troisième, c'est la complicité. Cette complicité la plus remarquable, c'est le produit du pays dont ils sont très fiers : la langue française. Cette langue, malgré sa beauté, est conçue des éléments complexes tels que le genre, la conjugaison, la prononciation etc. Et puis, ce qui est compliqué, c'est leur comportement. Ils veulent que tout soit parfait et bien organisé.

Le quatrième, les Français n'aiment pas parler de la vie privée. Se référer à une partie de la devise de la France, Liberté, nous considérons bien que les Français ont un mode de vie assez exceptionnel qui s'étend aux soins de santé, le travail et surtout les droits individuels. Ils voient que la liberté est la beauté de la vie, c'est leur privilège de ne pas vouloir partager des choses intimes avec les autres. Donc nous pouvons remarquer ici que pour eux, leur vie privée ne regarde qu'eux.

Nous ne pouvons pas éviter les préjugées lorsque nous étudions une langue et une culture étrangère. Cependant, cela ne signifie pas que c'est raisonnable de généraliser des gens d'un pays par des stéréotypes.

Par contre, savoir les stéréotypes culturels d'un peuple duquel vous apprenez leur langue comme la langue étrangère peut assez faciliter votre communication interculturelle avec les représentants de cette culture. En plus, ils aident de ne pas se retrouver dans une situation inconfortable pendant la communication. Par exemple, si vous savez que les Français aiment la ponctualité, vous évitez d'être en retard du rendez-vous avec eux. Si non, si vous serez en retard dès le première rencontre, par exemple, ça va laisser une mauvaise impression de vous. Encore, vous savez qu'ils n'aiment pas les questions concernantes de leur vie privée et vous évitez de ne pas poser ces types des questions pendant la conversation. Si non, vous allez tomber dans la situation inconfortable. Si quelque Français a vous dit franchement votre faute, vous n'allez pas vous étonner de cela, comme vous savez que c'est sa caractéristique. Pendant la conversation avec les Français évitez d'utiliser des mots d'une autre langue, par exemple l'anglais, en tant que vous savez les Français sont très patriotes de leurs langue nationale. Encore un exemple pour un bon conseil : disons que, vous avez des collaborateurs français et vous êtes organisateur d'une conférence avec eux, une conseil essentielle, essayez de faire attention à toutes les choses en détail, comme les Français aiment toujours tout soit parfait et bien organisé. Votre savoir des stereotypes français aide vous faire une belle conversation et laisser des bonnes impressions de vous, dans vos communicateurs français.

Donc, dans la conclusion vous pouvez vous-mêmes conclure que savoir les stéréotypes d'une culture de laquelle vous apprenez sa langue nationale comme la langue étrangère est assez important pendant la communication interculturelle avec les représantants de cette culture et langue.

La liste des litératures utilisées :

1. Маслова В. А. Лингвокультурология. Москва: Академия - 2001.

2. Семашко Т. Ф. Стереотип как фрагмент языковой картины мира / Статья // Мариупольский государственный университет, Украина - 2014.

3. Adisty Ardiany, Mercy Arifa, Zahra Noor : Les stéréotypes préjugés dans la communication interculturelle / Université Nanterre - 2009.

4. Lu Liu "Les stéréotypes en mouvement dans la communication interculturelle" / Thèse // Université de Strasbourg - 2018.

5. Usmanova Sh., Rixsiyeva G., Madaniyatlararo muloqot / O'quv qo'llanma // Toshkent - 2017. 


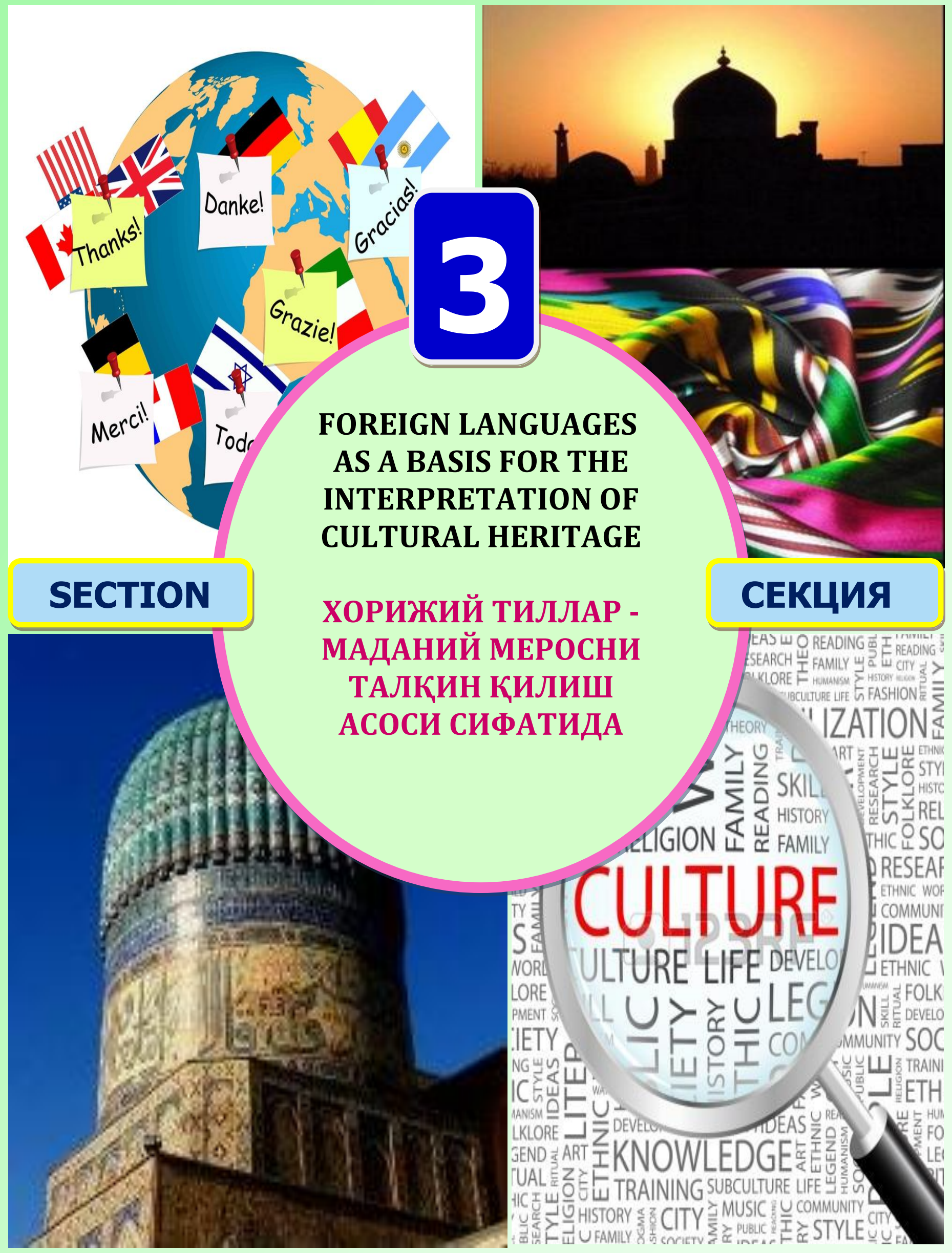


1. Холбеков Мухаммад Нурқосимович Ф.фб.д., СамДЧТИ профессори

2. Chi Daojia Tashkent State University of Oriental Studies

3. Anvarova Marifat Narzulloevna Cand. of phil.science, ass.professor of the Khujand State University, Tajikistan

4. Ли Диди Преподаватель Института Конфуция при СамГИия

5. Фазлиддинова Умеда студентка СамГИИЯ

6. Қаршибаева Улжан Давировна Ф.фб.д., СамДЧТИ профессори

7. Алиева Гулзода Тулқиновна СамдЧТИ ўқитувчиси

8. Рахимов $Х, P$. ЎзДЖТУ профессори

9. Хандамова Маърифбат Акрамовна СамДЧТИ доценти

10. Туробов Бекпулат Нусратуллаевич СамДЧТИ бўлим бошлиғи

11. Йўлдошев Улуғбек Равшанбекович фалсафба доктори, ЎзДжту

12. Меликова Мартаба Нумоновна $P h D$, доцент, Самаркандский государственный институт иностранных Языков

13. Аширбаева Дилором Равшановна Тошкент давлат шарқшунослик университети, муст. тадқиқотчи

14. Doliyeva Laylo Bo'riboyevna SamDCHTI o'qituvchisi

15. Ибатова Амира Шавкатовна ТАТУ Самарқанд филиали ассистенти

16. Islamova Guzal Tulkunovna National University of Uzbekistan, teach.

17. Ali Kaljanov アリ・カラジャノフ 博士 課程の学生ウズベキスタン共和国科学ア カデミーのカラカルパック支部、カラカ ルパック人文科学研究所

18. Mavlyanov Ulugbek Saidkasimovich Lecturer, SamSIFL

19. Мавлянова Тамилла Бахриллоевна Преподаватель СамГИия
21. Қиличева Гулрух Нарзуллаевна СамДЧТИ ўқитувчиси

22. Masharipov Jahongir Axmedovich Urganch Davlat Universiteti o'qituvchisi

23. Abdullayev Doniyor Bahodirovich Xiva tuman maktab o'qituvchisi

24. Hayitboyeva Oltinoy Shonazar qizi Urganch Davlat Universiteti talabasi

25. Музафбарова Луиза Умаровна cm. преподаватель СамГИИЯ

26. Мухамедов Азизбек Холмурат ўғли ЖДПи ўқитувчиси

27. Пирматова Озода Сафбарбоевна УрдУ ўқитувчиси

28. Расулова Сохиба Улуғбековна СамДЧТИ ўқитувчиси

29. Toshpo'latova Nargizaxon Mamarizayevna Farg'ona viloyati XTXQTMOHM o'qituvchisi

30. Турсунова Наргиза Хамрокуловна СамДЧТИ ўқитувчиси

31. Yahyoqulova Nigora Shuxratovna SamVMI o'qituvchisi

32. Negmatov Nodir Professeur de l'instit. des langues etrangeres de Sam

33. Холбекова Умида Мухаммадовн Преподаватель СамГИия

34. Sherqulov Sardor Komilovich ToshDO'TAU tayanch doktoranti

35. Ochilov E. QarshiDU

36. Egamnazarov Qobil Samarqand davlat chet tillar instituti o'qituvchisi

37. Кобилов Номоз Ўролович Самарқанд Давлат Университети мустақил изланувчиси

38. Халмуратов Иззатилла Наъматиллаевич Ўзбекистон Давлат Жахон Тиллари Университети магистр талабаси

39. Suvonov Behruz Samarqand davlat chet tillar instituti talabasi 


\section{ФРАНЦУЗ ҚАХРАМОНЛИК ЭПОСИ: \\ ("РОЛАНД ХАҚИДА ҚЎШИҚ" ДОСТОНИ)}

\section{Холбеков Мухаммад Нурқосимович филология фбанлари доктори, СамДЧТИ профессори}

Annotation: This article is about French heroic epos "Ballad about Roland". The development heroic legends in France.
Key words : Eastern countries, political struggle, military, western states, ancient, royal cycle, legend, song.

Жахон адабиётида халқ оғзаки ижодига мансуб эпик достонлар алохида ўрин эгаллайди. Улардан энг машхурлари қадимги юнон эпослари "Илиада" ва "Одиссея", фин эпоси "Калевала", англосаксон эпоси "Беовульф", француз эпоси "Роланд хақида қўшиқ", испан эпоси "Сид хақида қўшиқ", немис эпоси "Нибелунглар халқида қўшиқ", рус эпоси "Игорь жангномаси", туркий халқлар эпоси "Алпомиш", "Қирқ қиз" достонларини мисол қилиб келтириш мумкин.

Францияда қахрамонлик достонларининг шаклланиши IX-XI асрлар, яъни Шарқ ва Ғарб ўртасидаги харбий ва сиёсий харакатлар нихоятда жўшқин ва шиддатли тус олган даврларга тўғри келади. Францияда феодализмнинг жадал ривожланганлиги боис қироллик хокимятининг заифлашуви ва давлатнинг сиёсий тарқоқлиги авж олиш жараёни кетмоқда эди. Бу Франциянинг хаққоний поэтик тарихи бўлиб қолган қахрамонлик достонларининг чуқур ижтимоий ва сиёсий муаммоларини бир-бирига боғлиқлигини шартлаб қўйди.

Улар бизгача XII-XIV асрлар қўлёзмаоарида етиб келган, аслида анча қадимийроқ бўлган эпик қўшиқларнинг қайтадан ишланган нусхалари сифатида намоён бўлади. Бу қўшиқлар турли хажмдаги (100 дан 20000 сатргача бўлган шеърлар) муфассал поэма шаклига эга (уларнинг юзга яқин наъмуналари сақланган) дир.Уларда шеър банди (ёки лесса, тирада) ассонанс билан боғланган, кейинроқ эса шеър банди аниқ қофия билан алмаштирилган. Ушбу поэмалар chanson de geste ("улуғ ишлар хақида қўшиқлар) деган умумий номга эга булиб, учта циклга (даврага) бўлинади: яъни қироллик цикли, Гарен де Монглан цикли, Доон де Майанс цикли деб номланади.

"Роланд хақида қўшиқ" (Chanson de Roland) - француз қахрамонлик эпосининг энг машхур достони хисобланади. У бизгача бир нечта қўлёзмаларда етиб келган, улардан энг кадимий ва бадиий жихатдан мукаммали Оксфорд қўлёзмаси дея тан олинган. Оксфорд кўлёзмаси тахминан 1065 йилга оид деб топилган. Поэманинг келиб чиқиши ва унинг муаллифи тўғрисидаги савол хозирги давргача тадқиқотчилар ўртасида бахсмунозараларга сабаб бўлиб келаяпти. Индивидуализм назариясининг хозирги намояндалари, фольклоршунос - олим Жозеф Бедье изидан бориб, "Роланд хакида қўшик" поэмаси пайдо бўлишини XI аср охири- XII аср бошланишига олиб бориб тақайдилар, унинг муаллифлигини эса поэмада тилга олинган Туролд исмли шахсга мансуб деб хисоблашади. Неотрадиционализм назарияси тарафдорлари эса француз эпосини унинг мазмунида тараннум этилган тарихий воқеалар билан бир вақтда пайдо бўлганлигига, яъни VII-IX асрларла яратилган бўлиб, узоқ вақт оғзаки анъанада қисқа лирико-эпик қўшиқлар шаклида куйланиб келганлигини асослашга харакат қиладилар. "Роланд хақида қўшиқ" достонига ўша даврдаги тарихий хужжатларда кайд қилинган хаққоний воқеалар асос бўлган, хусусан, қадимшунос Эйнхарднинг "Буюк Карл хаёти тасвири" да баён этилган реал воқеалар асар мазмунига сингдирилган. 
778 йил франклар қироли Буюк Карл, испаниялик туб ахоли билан истилочи маврлар ўртасидаги жанжал-адоватларга бархам бериш учун Испанияга юриш қилади ва у ердаги бир неча шахарларни босиб олиб, Сарагосни қамал этади. Лекин, уни забт этаолмасдан, Францияга қайтишга мажбур бўлади. Пиреней тоғларидан ўтаётганда Буюк Карл харбий қўшинларининг арьергарди Ронсевал дарасида басклар томонидан уюштирилган қуролли хужумга учрайди ва тор-мор қилинади. Жангда, бошқа зодагон жангчилар билан бирга, Британия маркграфи Хруодланд хам халок бўлади. "Роланд хақида қўшик" достонида ушбу, бир караганда, унчалик ахамиятсиз бўлиб кўринган жанг воқеаси, халк бахшиларининг ижодий тасаввурлари орқали Она-юрт шарафига ватанпарвар қахрамонликнинг айлантирилган холда тараннум этилган.

Достондаги воқелик куйидаги мазмунда ёритилади. Мана етти йилдирки, Буюк Карл "субутсиз мунофик"лар билан жанг олиб бормокда. У кўпгина испан шахарларини босиб олган факат Саргос унга бўйсунмайди. Саргосда мустахкам ўргашиб олган қирол Марсилий қирол Карл қўшинининг тарк этишига фирибгарлик йули билан еришишга ахд қилади. У Буюк Карл олдига қимматбахо совға- тухфалар ва агарда у қамални очиб Францияга жўнаб кетса, христианлик динини қабул қилиш ваъдаси билан ўз элчиларини жўнатади. Обрўли аёнларидан бўлган барон Роланд маслахати билан Буюк Карл музокаралар олиб бориш мақсадида Марсилий олдига ўзининг вассали. Роландиииг ўгай отаси граф Ганелонни жўнатади. Хавф-хатарли топшириқни бажаришга мажбуран рози бўлган калондимоғ ва обрўталаб Гонелон аламини ичига ютиб, ўгай ўғлига нисбатан кек сақлаган холатда элчиликка рози бўлади. У Марсилнй билан хиёнаткорона шартнома тузади ва кайтиб, Буюк Карли сарацинлик қиролга ишонишга ва франкларни уз юртига олиб кетишга кўндиради. Ганелон режасига мувофик Пиреней тоғларининг Ронсевал дарасида Роланд бошқарувида бўлган француз қўшинларининг йигирма минг кишилик арьергарди Марсилийнинг тўрт юз минг кишилик қўшинлари хужумига учрайди. Маврлар билан бўлган шафқатсиз жангда Роланд ва унинг қуролдошлари Ронсевал дарасидан бир қадам чекинмасдан, халок бўладилар. Роланднинг ўлими олдида бурғу (алифон) чалиб йўллаган даъватини эшитиб, Буюк Карл орқага қайтиб келади ва жамики сарацин (гайридин) кўшини устидан жангда узил-кесил ғалабага эришади. Поэма соткин граф Ганелонни суд қилиш ва катл этиш сахнаси билан якунланади.

Шундай килиб, "Роланд хақида қўшиқ» достони мазмунида бамисоли иккита асмсий мавзу бир-бирига уйғунлашиб кетгандек кўринади. Биринчиси, Она-юрт шарафига бахшида бўлган кахрамонлик мавзуси, иккинчиси, энг сара француз рицарларининг халок бўлишига сабабчи бўлган феодал ўзбошимчаликни қоралаш мавзуси. Бу холат поэманинг бош қахрамонлари,- “гўзал Франция"(la douse France) учун хаётини бахшида этган халк кахрамони пахлавон рицарь Роландни ва феодал худбицлик ва узбошимчалик хакида кушиқ" достони иккита асосийї мавзу бир-бирнга кўринади. Бу холат поэманинг бош қахрамонлари - "гузал Франция" (la douce France) учун хаётини бахшида этган халқ қахрамони пахлавон рицарь Роландни ва феодал худбинлик ва ўзбошимчалик тимсоли бўлган граф Ганелоннинг қарама-қарши қўйилиши билан боғлиқ сахналарда ўз ечимини топади.

Достонда рицарь Ронланд қиёфасида чинакам ватанпарварлик рухияти мужассамлаштирилади, унда ўз Ватанига садоқат ва ўз қиролига вафодорлик тарихий объектив қонуниятларга асосланган уйғунлашиб кетади. Роналднинг қахрамонлик қиёфаси, айникса Ронсевал дарасидаги сўнгги жанг сахнасида тўла-тукис очилади. У ўзининг жасорати билан франклар кўшинини рухлантириб, душманларни ўнлаб, юзлаб яксон қилади. Бу холат унинг нутқида қуйидагича ифодаланган:

"Ким хаётини арзон-гаров бахридан ўтса - у қўрқоқдир.

Рицарлар, жангга! Маврларни чавақланг ўлгунича

Қиличларда жон таслим қилсин улар 
Гўзал Франция шаънига иснод келтирманг асло".

(рус тилидан Дилшод Арзиқулов таржимаси) Роланднинг

рицарлик жасорати гохида ўйламасдан кўрсатган қахрамонлигининг мағлубиятга олиб келишида кўринади. Роланднинг дўсти ва сафдоши граф Оливье маврларнинг беадад қўшинларини кўриб, ундан қирол Карлни ёрдамга чақириш учун Олифан бурғусини чалишини уч қайта сўраганда, Роланд ўз обрўси ва Франция шаънини тушириб кўймаслик учун уч қайта рад жавобини беради. Поэма муаллифи улардан бирининг хақлигини тан олишни истамайди, чунки "Оливье эс-хушли, акл билан иш юритса, Роланд довюрак, ор-помусли рицарь. Улар бу хислатлари билан бир-бирига тенг ва муносибдир".

Роланднинг халок бўлиши хақидаги хикоя сахнаси "довюрак рицарлар телбалиги"нинг хақиқий мадхияси тарзида мадх этилади. Жангда барча баходир рицарлари ва қуролдошларини йуқотиб, оғир яраланган Роланд ўлими олдидан баланд тепаликка чиқади, "яшил майса"га ётиб, ёнига олифан бурғусини ва қиличини қўяди ва Испанияга ўгирилиб, дейди:

Курол Карлга кўриниб турсин,

Кушин билан шу ерга кайтиб келганида,

Граф халок бўлди, бироқ жангда голиб чикди,

(рус тилидап Дилшод Арзиқулов таржимаси)

Поэмада қахрамонлар халок бўлаётган жангох воқеаси тасвирланган пайтда Франция худудида хам шиддат билан бўрон кўтарилди, бу халқнинг дарду-алами, қайғуси тимсолида куйланади:

Франция тепасида момақалдироқ гумбурлади,

Буцрон кутуриб, довул увиллади.

Шаррос ёмгир куйди, дул ёғилди,

Осмону-фалакда чақмоқ чақнади..

Бу Роланд номига мотам ва нола эди.

(рус тилидан Дилшод Арзикулов таржимаси)

Ватанларварлик хис-туйгуси "Роланд хақида қўшиқ" поэмасининг бошқа ижобий образларига хам хос, ва, аввало граф Оливье ва архиепископ Турпен қиёфасида бунинг акс этганини кўрамиз. Оливье, "Роланднинг мардонавор қуролдоши", - бу жасур ва довюрак жангчи ўз дўсти учун нобуд бўлиш бадном бўлишдан афзалроқ". Сўнгти дақиқагача у ёв-ғанимлар билан жанг олиб боради ва "гӯзал, азиз Ватан учун, қирол Карл ва Роланд учун жонини тикиб", халок бўлади.

Поэманинг ватанпарварлик пафоси мусулмонлик билан миллий-диний кураш ғояси ва бутун асарни ёриб ўтаётган ушбу курашда Франциянинг алохида юксак вазифаси билан чамбарчас боғлиқ. Бу архиепископ Турпен билан боғлик бўлган эпизодларда ёрқин намоён бўлади. Рухоний жангчи, у “ғайридин" лар билан мардона курашади, жангга бораётганлар ва халок бўлаётган франкларни дуо қилади. Ғурур ва буюк мехр билан Турпен ўз халқи хақида сўзлайди: "Бизнинг халк қўрқмасдир. У билан хеч қайси халк тенглашаолмайди".

Поэмадаги ватанпарварлик пафоси халқ рухига зид бўлган феодализм, бошбошдоқлик асосларини қоралаш, таъна қилишда хам намоён бўлади. Ушбу ғайриинсоний асосларни Ганелон образида кузатамиз. Поэмада унинг образи ўзининг мураккаблиги билан ажралиб туради. Сиртдан карагинда у хуштаъб инсон ("унинг қиёфаси кўркам, соғлом, бир кўринишда у жасур ва ғурурли. Агар у виждонли бўлганида, абжир йигит бўлар эди"), мардонавор ва довюрак жангчи, у судланиб жазосини олаётган сахнада хам ўзига яраша салобатли. Аммо Ганелон ўзининг худбинлик манфаатларини хамма нарсадан устун қўяди. Унинг Роланддан қасдини олиб аламдан чиқиш истаги Франциянинг энг сара жангчилари халок бўлишига сабаб 
бўлди. Шундай қилиб, феодал ўзбошимчалик Ватанга нисбатан хоинликка айланади ва поэмада қатъий қораланади.

«Роланд хақида қўшиқ" поэмасининг бадиий шакли унинг қахрамонлик мазмунига хамохангдир. Поэмада ишқий, маиший, комик мавзулар йўқ. Тасвирланаётган воқеаларнинг кенг қамровлилиги ва махобатлилиги хикояни кескин драматизм билан уйғунлаштириб келади. Ижобий қахрамонлар образи бекамикўст ва бўрттириб ку๊рсатилган, бу ўша даврларнинг хар бир эпик асари учун ўзига хос бўлган хусусиятдир (масалан, "довюракликда Роландга тенг келадигани йўқ, уни хеч бир инсон эпга солаолмайди", "граф Оливье яна етти юзта гайридинни ўлдирди" ва хоказо). Ўша давр рухи билан мувофиқ яккама-якка олишув ва жангларни тасвирлаш сахналари ўзининг рахмсизлик ва кўп қон тўкилганлиги билан хайратда қолдиради:

Жанг дахшатлидир, уруш рахмсиз ва унинг чеки йўқ, Французлар жасурона ва матонат билан жанг қилмоқдалар. Маврларнинг кулллари, қовурға ва суякларини чопмоқдалар,

Кийимлари орасидан найзаларини суқмоқдалар,

Яшил майса қондан қизил бўлиб кетди.

(Дилшод Арзиқулов таржимаси)

Образларни таъсирчан яратиш воситаларидан бири - уларни психологик кайфиятда бир-бирига қарама-қарши қўйишдир. Бу холатни тўғри ва қаттиққул Карлни - маккор ва нозиктабиат Масилийга; қизиққон ва ўзини босолмайдиган Роландга - ақл-идкок эгаси, мулохазали Оливье образларида кузатамиз. "Роланд хақида қўшиқ" поэмасининг халқчиллиги, унинг поэтикаси фольклорга яқин бўлганлигида сезилиб туради. Унда халқ оғзаки ижодиётининг ўзига хос хусусияти - такрорларнинг кенг ишлатилганлигида акс этади. Масалан, бу холат баъзи сюжетли моментларда такрорланади (Оливье Роланддан мужизакор олифан бурғусини чалишини уч марта сўраганда, у уч қайта рад жавобини беради, Роланд уз шамшири Дюрандал билан уч марта хайрлашади ва хоказо). Достон матнида сўзлар ва сўз бирикмалари қайта-қайта такрорланади. ("Қаерга юборилганлигини Роланд билди...", “ Арьегардга жўнатилганлигини Роланд билди..." ва хоказо).

«Роланд хақида қўшиқ" поэмасида параллелизмлар хам кўп учрамоқда: ўн иккита французлик пэрларга ўн иккита сарацинлик пэрлар қарши чикмоқда, Марсилий хузурида харбий кенгаш сахнаси - Буюк Карл саройидаги сахнасига айнан ўхшаш ва бошқалар. Доимий васф кўплиги поэманинг халқдан келиб чиққанлигидан далолат беради: поэмада Буюк Карлни тасвирлашда "соқоли оқ"лиги, "сочи оқ"лиги унинг донолигига шаъма қилинади. Франция - "гўзал", "жонажон"; Ганелон-“сотқин”, "хоин"; шамшир - "шаффоф", "пулатдан" ва хоказо.

"Роланд хақида қўшиқ" достонининг бадиий негизида асосий жойни башоратли тушлар ва турли-туман сехрли аломатлар эгаллайди (Роланд халок бўлишидан дарак берувчи башоратли тушни Карл икки бор ку”ради), халок бўлганлар устидан нолалар (Роланд Оливье жасади устида аза тутиб йиғлайди, Карл эса Роланд жасади устида кӱз ёши тўкади), буларнинг хаммаси халк оғзаки ижодига хосдир. Поэма кескин, оддий ва махобатли тилда, қадимги французча шеър билан ёзилган, бу эса поэманинг қахрамонлик мазмунини қизиқарли тарзда баён қилиб берган.

\section{Фойдаланилган адабиётлар:}

1.Волкова 3.Н. Эпос Франции. - М.: Наука , 1984.-318с

2.La Chanson de Roland Avec une traduction nouvelle, une introduction et des notes de Edmond Souffler, - Angers, 1943. - 184p

3.Histoire de la littérature françaire: Moyen Age .- Bord, 1967.-242p 


\section{THE CONTRASTIVE ANALYSIS OF CHINESE PREPOSITIONS "GĚI, DUİ" AND CORRESPONDING UZBEK AUXILIARIES / AFFIXES}

\section{Chi Daojia \\ Tashkent State University of Oriental Studies}

Annotation: Chinese is an isolated language. Prepositions are used to express grammatical meanings. Generally, prepositional phrases are composed of nouns. The whole prepositional phrases are mostly used as adverbials in front of sentence predicates. Uzbek is a cohesive language,affixes and auxiliaries are abundant. Affixes are placed after body parts of speech to express grammatical meanings such as location, time and object. There is no "preposition" classificationin Uzbek, and most of them correspond to Chinese prepositions as "affixes or auxiliaries". This paper adopts four steps of "contrastive analysis". Firstly, it describes the Chineseprepositions "Gěi(for/to), Duì(to)" and its correspondingUzbekaffixes or auxiliaries. Secondly, the Chinese prepositions "Gěi(for/to), Duì(to)" are compared with the corresponding Uzbek affixes or auxiliaries. Finally, based on the results of contrastive analysis, this paper predicts the transfer in the acquisition of Chinese prepositions "Gěi(for/to), Dui(to)" by Uzbek speakers.

1. Introduction. The so-called "contrastive analysis" refers to a method of linguistic analysis that compares the systems of the two languages to reveal their similarities and differences. In 1957, Lado pointed out in the book Intercultural Linguistics that projects that are similar to the learner's mother tongue are easier for them, and it is difficult to learn from their different mother tongue projects(Cited by D. J. Chi \& S. Hashimova,2019). Therefore, a systematic comparison of the two languages can predict where the learner may or may not have difficulty in learning the target language, thus adopting more effective second language teaching measures in the teaching. According to Lado(1957), the process of contrastive analysis generally has four steps:

First, description. The target language and the learner's first language are described in detail and in detail as the basis for comparison. In this paper, the modern Chinese prepositions and corresponding Uzbek auxiliaries/affixes are described in detail.

Second, selection. Choose some meaningful language projects or structures to compare between the two languages.

Third, comparison. Compare the selected language items or language structures in the two languages to find the same points and differences between the two languages.

Fourth, prediction. On the basis of comparison, predict the difficulties and errors that may occur in the learning of second language(Cited by D. J. Chi 2019) .

Chinese and Uzbek belong to two completely different grammatical systems. Chinese belongs to the Sino-Tibetan language family and is an isolated language. Uzbek belongs to the Altai language family and is an adhesive language. The grammatical structure of the two languages is quite different. There is no "preposition" in Uzbek, only some "affixes" or "auxiliaries" corresponding to Chinese prepositions. Therefore, many Uzbek students find it difficult to learn Chinese prepositions. In addition, Chinese prepositions themselves are rich and diverse, and their usage is changeable, if the teaching methods used by teachers are not scientific enough, it will inevitably lead to a large number of errors in the use of Chinese prepositions by beginners.

This paper selects Chinese prepositions "Gěi(for/to), Duì(to)" and compares them with its corresponding Uzbek auxiliary words or affixes to find out their similarities and differences, and predicts the transfer that Uzbek speakers may have in their learning. 
2. Comparison overview. According to the "Chinese Proficiency Test Vocabulary Outline", a total of 41 prepositions were collected. There is no such classification as "preposition" in Uzbek, but there are "affixes" or "auxiliaries" corresponding to the meaning of Chinese prepositions. The specific comparison is as follows:

Table 2-1 The comparison of Chinese Prepositions and Uzbek Affixes / Auxiliaries

\begin{tabular}{|c|c|c|c|c|c|}
\hline No. & $\begin{array}{l}\text { Chinese } \\
\text { preposition }\end{array}$ & Corresponding Uzbek & No. & $\begin{array}{l}\text { Chinese } \\
\text { preposition }\end{array}$ & Corresponding Uzbek \\
\hline 1 & 按 àn & -ga ko'ra & 22 & 和 hé & bilan \\
\hline 2 & 按照 ànzhào & -ga asoslanib & 23 & 跟 gēn & bilan \\
\hline 3 & 依照 yīzhào & -ga tayanib & 24 & 同 tóng & bilan,hamda \\
\hline 4 & 照 zhào & -ga asoslanib & 25 & 随 suí & bilan \\
\hline 5 & 对 duì & -ga & 26 & 与 yǔ & bilan \\
\hline 6 & 给 gěi & -ga & 27 & 将 jiāng & $-n i$ \\
\hline 7 & 往 wăng & -ga qarab & 28 & 把 bǎ & -ni \\
\hline 8 & 向 xiàng & -ga & 29 & 叫 jiào & tomonidan \\
\hline 9 & 朝 cháo & -ga & 30 & 被 bèi & tomonidan \\
\hline 10 & 从 cóng & -dan & 31 & 比 bř & nisbatan \\
\hline 11 & $\begin{array}{l}\text { 从...到 } \\
\text { cóng...dào }\end{array}$ & ...dan...gacha & 32 & 趁 chèn & foydalanib \\
\hline 12 & $\begin{array}{l}\text { 从...起 } \\
\text { cóng...q1̌ }\end{array}$ & -dan boshlab & 33 & 冲 chōng & asoslanib \\
\hline 13 & 除 chú & -dan tashqari & 34 & 当 dāng & qachonki \\
\hline 14 & 打 dǎ & -dan & 35 & 关于 guānyú & haqida \\
\hline 15 & 距 jù & dan...gacha(masofa) & 36 & 经过 jīngguò & orqali \\
\hline 16 & 距离 jùlí & dan...gacha(masofa) & 37 & 就 jiù & darhol \\
\hline 17 & 离 lí & -dan(masofa) & 38 & 顺 shùn & bo'ylab \\
\hline 18 & 为 wèi & uchun & 39 & 通过 tōngguò & orqali \\
\hline 19 & 为了 wèile & uchun & 40 & 由 yóu & sababli \\
\hline 20 & 以 yı̌ & uchun,maqsadida & 41 & 由于 yóuyú & sababli \\
\hline 21 & 在 zài & -da (joyga nisbatan) & & & \\
\hline
\end{tabular}

It can be seen from the above table that Chinese prepositions are rich and varied, while the number of affixes or auxiliary words corresponding to Chinese prepositions in Uzbek is relatively less, and the same affix or auxiliaries are often translated into multiple Chinese prepositions. For example, the suffix "-ga" in Uzbek can be used to translate nine prepositions into Chinese: "Duì(to)、Gěi(for/to)"、Wăng(toward)、Xiàng(toward)、Cháo(toward) 、 àn(according) 、 zhào(according) 、 ànzhào(according to) 、yīzhào(according to)"; the auxiliary word "billan" in Uzbek can be translated into five Chinese prepositions: "Hé(and)、 Gēn(and)、 Tóng(with) 、Suí(follow)、Yǔ(and)". Although the semantics of some prepositions in Chinese are similar, the specific usages are not the same, which makes a certain difficulty in acquiring Chinese prepositions for Uzbek students.

According to"The Eight Hundred Words of Modern Chinese" (Lu Shuxiang ed. 1999). The donate-accept preposition "Duì(to)" and "Gěi(for/to)" are selected to contrast with its corresponding Uzbek affixes/auxiliaries.The following is a detailed introduction of the usage of the 2 prepositions and contrast with the corresponding uzbek. 
3. Contrastive Analysis of Chinese Prepositions "Gěi(for/to), Duì(to)" and Corresponding Uzbek Affixes/Auxiliaries

3.1 The preposition "Gěi(for/to)"

According to "The Eight Hundred Words in Modern Chinese" (Lu Shuxiang ed. 1999), the preposition "Gěi(for/to)" generally has four usages:

(1) Introducing the recipient of the action.

(1) Chinese:Zuótiān bàba gěi wǒ jiăngle yígè gùshi.

Uzbek:Kecha otam menga hikoya aytib berdi.

English:My father told me a story yesterday.

(2) Chinese:Bă zhè běnshū jiègěi wǒ kànkan.

Uzbek:Bu kitobni menga o'qishga berib tur.

English:Lend me the book to have a look.

"Gěi" indicates the recipient of the introduction action, which can be used before the verb (sentence (1)), and its sentence pattern is generally expressed as "A+ Gěi(for/to)+B+V.". It can also be used after the verb (sentence (2)), its sentence pattern is generally expressed as "A+V.+Gěi(for/to)+B". The affix corresponding to the preposition "Gěi" in Uzbek is "-ga", but there is only one sentence pattern of "A+B-ga+V.". The affix "-ga" is usually attached to action recipient "B".

(2) "Gěi wǒ(give me) + verb"

(1) Chinese:Wǒde shǒujī bújiànle, gěi wǒ zhǎozhăo。 (for me / help me)

Uzbek:Meningtelefonimko'rinmayqoldi, mengauniqidirishibyubor.

English:My phone is missing, find it for me.

(2) Chinese:Wǒ bùxiǎng jiàndào nǐ, gěi wǒ chūqu. (Strengthen tone)

Uzbek:Men seni ko'rishni xohlamayman, ketishga ijozat ber.

English:I don't want to see you, get out.

"Gěi wǒ+verb" is used in command sentences. Generally, it has two meanings: one is "for me" or "help me" (sentence (1)); the other is to strengthen the mood to express "command" (sentence (2)). The first usage, there is a corresponding usage "Menga" in Uzbek. But for the second, there is no corresponding usage in Uzbek, and only through free translation.

(3) Indicate"to ; toward"

(1)Chinese: Gěixiăoháijiănggùshi.

Uzbek:Yosh bolalarga ertak aytish.

English:Tell a story to children.

(2) Chinese:Gěilăoshīxínglǐ.

Uzbek:O'qituvchiga salm bermoq.

Give a salute to the teacher .

(3) Chinese:Qı̌nggěitādàoqiàn.

Uzbek:Iltimos,Undan uzur so'ramoq.

English:Please apologize to him.

"Gěi" indicates the object of the action, the meaning is like"to"or "toward", and its sentence is generally expressed as "Gěi(to)+B+V.". There is also a corresponding usage in Uzbek. The same as "Gěi(for/to)" is also the affix "-ga", and its sentence is generally expressed as "B-ga+V." (sentence (1) (2)). But before some verbs, Uzbek can't be translated into "-ga", but "-dan" (sentence (3)).

(4)Indicates passive.

Chinese:Tāgěi lăoshī pīpíng le.

Uzbek:U o'qituvchisidan tanbeh oldi.

English:He criticized by the teacher.

"Gěi" indicates passive, used for passive sentences, and is similar to the expression of "Bèi (by) 、 Jiào(called) and Ràng(let)", and its sentence is generally expressed as "A+ 
Gěi(by)+B+V.". There is also a corresponding usage in Uzbek, but the corresponding is not the affix "-ga", but the auxiliary word "tomonidan", and its sentence is generally expressed as "A+B+tomonidan+V.". The Uzbek language has only one word for passive expression, and the object of the application is in front of "tomonidan".

3.2 The preposition "Duì(to)"

(1) Indicates the object of the action;

Wǒ yǐjīng duì māma shuōle

Men allaqachon onamga aytdimki.

I already said to my mother.

"Duì" indicates the object of the action, and its sentence is generally expressed as "A+Duì(to)+B+V.". There is also a corresponding usage in Uzbek. The same as "Gěi(for/to)" is also the affix "-ga", and its sentence is generally expressed as "A+B-ga+V.". The affix "-ga" is also attached to the action object "B".

(2) Indicates treatment.

Bàba duì wǒmen hěn guānxīn.

Otam menga juda qayg'uradilar.

Dad is very concerned about us.

"Dui" indicates treatment, the usage is similar to the first usage, and its sentence is generally "A+Duì(to)+B+V.". The corresponding Uzbek is also the affix "-ga", and the sentence is also "A+B-ga+V.".

(3) "Duì...láishuō"( For ...) . E.g:

Duìwǒláishuō, xuéxí hěn kuàilè.

Men uchun o'qish juda qiziqarli.

For me, study is very happy.

"Dui" means that from the perspective of someone or something, it is often used in the fixed sentence pattern "for...".There is no such usage in Uzbek, and sentences can only be translated through "meaning translation."

Chinese prepositions are rich and varied, and they are difficult to use. Students often avoid using them because "the use of prepositions and collocations is limited. It is this limitation that enables learners to use only one preposition in combination with other words and master prepositions in syntactic changes "(Zhao Kuixin 2002).

4. Conclusion. Based on the above Contrastive Analysis, the following transfer predictions are proposed for Chinese learners whose mother tongue is Uzbek.

Because there are no preposition classification in Uzbek language, the prepositions in Chinese and the corresponding in Uzbek language are mostly affixes or auxiliary words, and the word order of affixes or auxiliary words in Uzbek language is different from that in Chinese prepositions.Therefore, most learners will produce negative transfer effect when they acquire Chinese prepositions. The details are as follows:

When "Gěi" indicates passivity, used for passive sentences, and is similar to the expression of "Bèi (by)、Jiào(called) and Ràng(let)". The word "Bèi" is often used to express passivity in Chinese, but learners may strange that "Gěi" can also express passivity. Therefore, when learners do translation exercises, they may not know this usage, but translate the meaning of "Gěi" into the commonly used "to/for(-ga)".E.g:"Tā gěi lăoshī pīpíng le(U o'qituvchisidan tanbeh oldi)",the learner may produce errors"*U o'qituvchisiga tanbeh oldi".

The same affixes or auxiliary words in Uzbek can express multiple Chinese prepositions, which is prone to errors.For example:the affix "-ga" in Uzbek can express the grammatical meaning of object, treatment, space, direction, etc. It can be translated into nine prepositions in Chinese: "Duì(to)、Gěi(for/to)"、Wăng(toward)、Xiàng(toward)、Cháo(toward) 、 àn(according)、zhào(according)、 ànzhào(according to)、yīzhào(according to)". Influenced by the negative transfer of mother tongue and knowledge of the target language, learners may 
confuse the usage of the above nine prepositions.E.g:"Bàba duì wǒmen hěn guānxīn(Otam menga juda qayg'uradilar)",the learner may produce errors"*Bàba gěi wǒmen hěn guānxīn".

\section{References:}

[1] 2001 National Chinese Proficiency Test Committee Office Examination Center "Chinese Level Vocabulary Chinese Character Grade Outline", Economic Science Press.

[2] 2002 Chinese Language Proficiency Test Department of the Chinese Language Proficiency Test Office, "Chinese Proficiency Level Standards and Grammar Grades" Higher Education Press.

[3] Brown, H. D. 2005. Principals of language learning and teaching (5th ed.). New York: Pearson Education.

[4] Chi Daojia 2019 The Contrastive Analysis of Modern Chinese and Uzbek Consonants. American Journal of Research, No.3-4, Michigan,USA.

[5] Chi Daojia,Hashimova S. 2019 The Contrastive Evaluation On Modern Chinese and Uzbek Vowels.International Journal of Engineering and Advanced Technology (IJEAT), Volume-9 Issue-1. India:Blue Eyes Intelligence Engineering\& Sciences Publication

[6] Ellis, R. 1985. Understanding second language acquisition. Oxford: Oxford University

[7] Gass \&Selinker 2008 Second language acquisition: An introductory course(Third edition). New York:Routledge.

[8] Gulibanumu 2015 Uzbek Language Course, Beijing: Central University for Nationalities Press

[9] Huang Borong, Liao Xudong 2011 Modern Chinese (updated five editions), Beijing: Higher Education Press.

[10] James, C. 1980. Contrastive Analysis. London: Longman.

[11] Liu Xun 2000 Introduction to Teaching Chinese as a Foreign Language,Beijing: Beijing Language and Culture University Press.

[12] Liu Xun 2002 Practical Chinese Textbooks [M], Beijing: Business Press

[13] Lu Shuxiang 1999 "Modern Chinese 800 Words" (Revision) , Beijing: Commercial Press

[14] Shao Jingmin 2008 General Introduction to Modern Chinese (2nd Edition), Shanghai: Shanghai Education Press

[15] Whitman, R. L., 1970. Contrastive Analysis: Problems and Procedures. Language Learning, Volume 20, pp.191-197.

[16] Yang Jizhou 1999 Chinese Course, Beijing Language and Culture University Press

[17] Zhao Kuixin, 2002, "Investigation of Foreign Students Studying and Using Chinese Prepositions" World Chinese Teaching, No. 2, P100-106

\section{THE ROLE OF «LATAIF AL-AMSAL» IN THE DEVELOPMENT OF PAREMIOLOGICAL DICTIONARIES IN THE ARABIC AND PERSIAN-TAJIK LITERATURE}

\section{Anvarova Marifat Narzulloevna candidate of philological science, associated professor of the Khujand State University, Tajikistan E-mail : m.anvarova2018@mail.ru}

Annotation: The article viewed on the issue concerned that "Lataif al-Amsal"created by Rashiduddin Vatvat was considered to be the most important source targeted at a development and diffusion of paremiological dictionaries written in the Persian language. The authors of the majority of analogous dictionaries borrowed from the book belonging toVatvat,first and foremost, Persian interpretation of proverbs; comparative analysis dealing with two paremiological dictionaries with "Lataif alAmsal" by Rashiduddin Vatvat testifying it. In a nutshell, we conclude that the former in question was the most important source of development and diffusion in reference to paremiological dictionaries written in the Persian language.

Key words : comparative analysis, statistical aspect, interaction, Arabic and Persian proverbs.

Comparative analysis concerned with the content of "Lataif al-Amsal" with other analogous dictionaries, compiled before our work under consideration, shows that Rashiduddin Vatvat, in the course of creating his book, mainly proceeded from "Majma`al- 
Amsal" belonging to the pen of Maidan Nishopuri. "Lataif al-Amsal" by Vatvat is considered to be the first bilingual paremiological dictionary in which as the author himself confesses, "legends and stories related to them (namely to proverbs and sayings - M.A), he wrote in Persian in order the use from the dictionary were a complete universally beneficial" $[8,40]$.

Certainly, the book was the first experience of a bilingual paremiological dictionary, and due to tales and stories written in the Persian language, most authors of dictionaries and other scientists often resorted to comments and interpretations by Vatvat in their works referring to subsequent centuries. A comparative analysis of the content of "Lataif al-Amsal" with dictionaries compiled after Vatvat's work testifies to the fact that the succeeding authors used Rashiduddin`s work very productively and convincingly. It is stated that Rashiduddin Vatvat made a great contribution into the formation and development of paremiological dictionaries in Persian-Tajik literature.

One of the compositions in which one can deal with the influence of "Lataif al-Amsal" by Rashiduddin Vatvat is considered to be "Nafais al-Funun fi Arais al-Uyun" by Shamsuddin Muhammad Omuli. Omuli`s work presents an authoritative encyclopedia being the twelfth science (fan), which is devoted to paremiology, upon the whole. After a reproduction of the essence of proverbs studies, the author starts to enumeration of proverbs and their translation as well. Comparison of the two interesting works shows that Omuli in the course of his work used "Lataif al-Amsal" by Vatvat in most cases. Shamsuddin Muhammad Omuli borrows Vatvat's text without unchanged form. The generality of the two books can be noticed immediately by comparing of their prefaces. In a small foreword of the preface to "Lataif al-Amsal," Vatvat marks profits and benefits of proverbs and their collection as well [8,39-40].

Shamsuddin Muhammad Omuli gives a very brief characteristics and the meaning of the proverb in his introduction to the book. By volume of the introduction to the book, Omuli bears a resemblance with the preface to the book by Vatvat, the reason for the book writing being excluded.

The similarity of the two works is mostly noticed in the proverbs interpretations in the tales and stories adduced by the authors and aimed at explaining the emergence of proverbs. First and foremost, the generality is manifested in the fact that Omuli chooses and comments on the same proverbs as Vatvat does.

Undoubtedly, Omuli used Vatvat's dictionary as the primary source. Although Omuli, unlike Vatvat, does not translate his own proverbs, but in the translation of the causes of their occurrence, cases of usage, tales and short stories related to them, there is a clear generality discerned between the two books. Namely:

"Lataif al-Amsal"

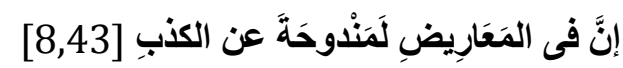

Translation of the proverb: Non-committal speeches (hints) get rid of lies.

This proverb was adduced by Imran ibn Husayn. He is the Prophet's disciple. The sense of the proverb lies in utterance of enigmatical speeches in order to move from an open enunciation to allegory, so that to avoid an obvious and useless lie.

The given proverb is used when someone resorts to lies, unpleasant and forced, burdening and embarrassing.

Short story: In our time there lived an unjust tsar who compelled a pious man to compose a document on his (king-MA) justice and generosity, to receive signatures of people by threats and intimidation. The learned pious husband wrote that the external state of all Muslims, especially that one rulers who are shepherds of prayers and defenders of the country, is such that as soon as they put on the gown of good (that is, they become kings), they try to thank the Philanthropist and are inclined to justice and tranquility and move away from the parking of injustice and debauchery, and "ما شهد إلاب ماء لمت (I cannot confirm until I see it). These words, which he wrote allegorically, are correct and if he wrote openly that the king 
is just and God-fearing and far from injustice and atrocities, this would be a lie and would contradict the Shariat and nobility (futuvvat). And everything that looks like this, refers to selected allegories and permissible tricks $[2,43]$.

\section{«Nafais al-Funun»}

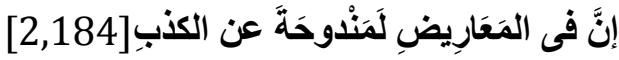

After the Arabic text of the proverb Omuli adduces the interpretation: The relevant proverb was said by Imran ibn al-Husayn, who was one of the Prophet's disciples. Namely, to use mysterious words and to pass from direct speech to parables is a way of avoiding obvious lies. This proverb should be resorted to when someone wants to lie and supposes that he has to do it [2,184-185].

A comparative analysis of the adduced proverb shows that its interpretation in these books is practically one and the same. First of all, both sources ascribe the proverb to Umran ibn Husayn who was an adherent of the Prophet. The interpretation text of the book belonging to Omuli unambiguously testifies that the author borrowed it with minor changes from Vatvat's work. The story in the book of Vatvat is more detailed, Omuli in his literary production "Nafois al-Funun" adduces the same story with abridgements, and in a more concise form.

In the style of the reproduction of the tales, along with similarity, there are certain differences as well. For instance, everywhere in his book before giving the story text Vatvat adduces the headline "Hikoyat". Omuli in the twelfth chapter of his book obligatorily "Nafais al-Foonun" does not resort to the title "Hikoyat" at all.

Let`s adduce one more example. "Lataif al-Amsal"

$$
\text { [8,46] }
$$

Translation of the proverb: That one who addresses you with malediction is enflamed [8, 69-70].

As we see, Omuli pays particular attention to the usage of the proverb: and he even does not give a Persian translation of the proverb itself. The Persian equivalent of the proverb is identical in both books. "Lataif al-Amsal"

The difference between the two correlative sources is primarily due to the fact that Vatvat's interpretation in regard to the proverbs is more detailed in comparison with "Nafais al-Fonun". The given consideration confirms the comparison of the first proverb out of "Nafais al-Fonun" with proverb № 6 from "Lataif al-Amsal".

Proverb: Flaunting and boasting inflict damage on virtue.

آفَة الجمَالِ الخُيَلاءُ

These are the words of the Prophet. However, it is necessary to know that khuyalo flaunting and boasting are of two kinds: the first one is that God the Almighty loves and the secondone is that which God the Almighty does not like. That khuyalo', which God the Almighty loves is standing out vividly in braggin before enemies in the arena of the battle, reproof and battle with a spear. As Muhammad ibn Ishok ibn Yazor Prophet (s) tells us, on the day of the battle Uhuda went out in a double hauberk and had a sword in his blessed hand. The Prophet (s) asked: Who will take this sword from my hand as it should be? Emir Umar belonging to genuine Muslims hurried (to the Prophet (s)) and said: "Me, O Prophet of God"! The Prophet (s) turned away from him and did not give him a sword. He askedfor the second time: "Who will take this sword out of my hand as it should be?" Zabir ibn al-Awvom hurried and said: "I, O Prophet of God." The Prophet turned his back on him and did not give him a sword. For the third time he questioned, "Who will take the sword from my hand as it should be?" Abu Dujon Simok ibn Haras al-Ansori hurried and said: "O Prophet of God (s), how is it proper to take this sword"? The Prophet (s) said: "It is fitting for him to grip and beat the enemies of the religion of God the Almighty so much that he bisected." This Abu Dujon was very brave and courageous. His famous habit and feature was that he gracefully entered the arena of battle and flaunted himself before enemies and, in spite of their large number, did not 
consider them as people. On the day of the battle his sign was a red scarf and they recognized him by it. And when he was tying a red handkerchief on the battlefield, people knew that in battle he would show excessive courage and the enemy would be exterminated. Taking the sword from the hand of the Prophet (s), he took out a red kerchief and tied his head and, reading "rajas" and demanding foes, he stood out into the battlefield and began to march between the two lines. The Prophet (s) said: "God does not like such behavior, except in this

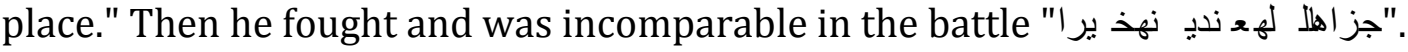

Thet boast which God the Almighty does not like is when man is proud of bad deeds and unacceptable acts and flaunts arrogantly and conceitedly with aplomb.

The relevant proverb must be said there where someone is proud of his beauty and perfection and due to selfishness and intention to impress with his beauty, does not pay attention to his friends and does not notice them [8,44-45].

It is obvious that, Rashiduddin Vatvat speaks about the origin of the proverb in minutest details and starkly precisely. The author of "Nafais al-Fonun", unlike Vatvat, expounds the above information very succinctly:

- The above proverb was spoken by the Prophet (s), and it must be said when someone is too proud of his beauty and perfection and owing to selfishness does not show respect for people, in general. It is necessary to know that arrogance is of two kinds. The first kind that God the Almighty does not like and this is arrogance arising from haughtiness and hubris and pride manifested with bad deeds and unrighteous perpetrations [2,185].

At the terminating part of the interpretation belonging to Vatvat and a brief commentary on Omuli, there is a similarity, especially in the part where the word "khuyalo" (smugness, arrogance, overconfidence) is explained being based on the Prophet's statement. Generality manifests itself not only in the aspect of content, but in the style of reproduction either, in the usage of the same words and phrases, in particular. Let's we consider the last fragment in the two books

"Lataif al-Amsal": "That arrogance ("khuyalo"), which God Almighty does not like is haughtiness arising from bad deeds and unacceptable actions, displayed in conceit with aplomb."

"Nafais al-Fonun": "It is important to know that arrogance is of two kinds: one type that God does not like is all-powerful, it is to stride with arrogance and hubris evincing them with bad deeds and unrighteous perpitrations."

We adduce some more examples proving that the main source of the book "Nafais alFonun" was "Lataif al-Amsal" by Vatvat.

ترك الظبي ظله [8,54]

Translation of the proverb: The gazel-doe left its house, place and abode. The meaning of the word "zil" in this case is "the house of a gazel-doe", under whose shadow it is. When the hunter finds its abode, the doe leaves it. They say that the doe runs away and does not ever return to that place any more:

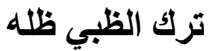

The proverb is used when somebody has an aversion to something, and he leaves this place and never more approaches it $[8,53]$.

Exactly, using the same style, words and phrases, Omuli adduces the relevant proverb in his book called "Nafais al-Fonun": : ت ركال ظ ب بظ له - The meaning of the word "zil" in the given proverb is the house of the gazel-doe where it lives and the hunter`s approach to this place makes the gazel-doe being excited, and because of fear it escapes from the hunter and does not return there anymore. Therefore, they say: ت ركال ظ بـ يظ له

The proverb is adduced when somebody has an aversion to something, and he leaves this place and never approaches it [2,191-192].

It should be underscored that Omuli corrects the tautology, which crept into the text of Vatvat`s book. In the first sentence of Habib Donishomuz`s edition, the word "ma`ni"(sense) 
was printed twice by mistake: "Ma`noi zil dar in "ma`onoi" honai ohust" (Here, zil is used a doe`s house). Omuli adduces the correct variant of the text: "Ma`noi zil dar in"masal"honai ohust" (In this proverb zil means "doe`s house").

One can confidently assert that the error crept into the text under the title of "Lataif alAmsal" within the publication. Another example:

Translation of the proverb: The end of spring, the summer comes.

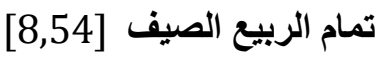

Omuli repeats the interpretation of Vatvat without minor changes and, moreover, he does not cite any case of using the proverb.

As we see, Omuli introduces three minor changes into Vatvat's text: "bahor" instead of "bahoron", "chun" instead of "va", "guyand" instead of "guftand".

In certain cases, Vatvat adduces the poetic Persian equivalent of the proverb:

[8,57 [أتعب من رايض مهر

Translation of the proverb: Exhausted more than a foal tamer. Who breaks in a foal, undoubtedly, suffers torments and hardships and difficulties in treating it, and the given proverb is close to this one:" لا يعدم شقى مُهر اً " ل

Beyt:

The foal tamer suffers, therefore he

$$
\text { ميزند تازيانه هموارش }
$$

رنج بيند ز كرّه رايض از آن

Constantly beats it with a whip. [8.57]

Later on, Vatvat adduces a satirical short story which has no relation to the proverbial content principally, in spite of the fact that one of his heroes is a tamer. Omuli gives both the interpretation of the proverb and the short story with abridgements and minor changes as well.

Translation of the proverb: Everyone who wants to tame a foal will suffer in the (process) of taming inevitably. They say that one woman told the tamer: you have a very difficult job, because a search for food is bound with your backside (she meant breaking a foal - M.A). The tamer said: Oh, mistress, do not be upset, for the distance between the tool of my profession and that one of yours is no more than four fingers. The relevant proverb is adduced when someone experiences difficulties and hardships owing to a certain case $[2,192]$.

It is worth mentioning that Omuli misses the second Arabic proverb. Moreover, Omuli shortens also the Persian poems translated by Vatvat in order toclarify the precise sense of the proverb. One can consider that thebeitis Persian equivalent of the Arabic proverb to a certain extent. It's necessary to state that Omuli follows Vatvat's principle in regard to cititation of Persian versified fragments in certain cases. For instance, after the Arabic

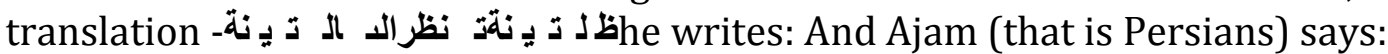

Makun bo badomuz hargiz dirang,

Ki angur giradzi angur rank. [5,193]

It is not necessary to treat a rude person, excessively considerately

For grapes are becoming ripe, looking at other grapes.

(Russian equivalent of the proverb: With whom you play that one will sway over you with his manners). The source of the illustrative versified fragment of Omuli is also the well-known Persian-Tajik proverb of today undoubtedly: "A neighbor learns a lesson from another neighbor's condition the grapes become red (ripen), looking at other grapes."

A comparative analysis of two literary works allows us to make the following conclusions:

a) The work titled "Lataif al-Amsal" by Vatvat is considered to be the basic source of the twentieth section of "Nafais al-Fonun" by Shamsuddin Muhammad Omuli devoted to Arabic proverbs and their interpretation in Persian;

b) Omuli resorted to the principles and style of Vatvat`s work creatively; 
c) Shamsuddin Muhammad Omuli chose the principle of abridged reproduction of the material out of Vatvat's book;

d) Here, Omuli does not adduce Persian translation of the proverbs;

e) In case every chapter of Vatvat's book contains ten proverbs, then in the sections of Omuli's composition the proverbs are placed in the digital range from 10 to 22 . Thus, in the term of the alphabet the section of the letter "Alef" contains 22, "bo" 20, "to" -20, "kof" -15, "mim" -15, "lom" -12 proverbs. Consequently, the total number of proverbs in "Nafais alFonun" is more than in Vatvat's work.

Designing on the premise of the above-mentioned analysis, one can come to the conclusion that "Lataif al-Amsal"created by Rashiduddin Vatvat was considered to be the most important source targeted at a development and diffusion of paremiological dictionaries written in the Persian language. The authors of the majority of analogous dictionaries borrowed from the book belonging toVatvat,first and foremost, Persian interpretation of proverbs; comparative analysis dealing with two paremiological dictionaries with "Lataif alAmsal" by Rashiduddin Vatvat testifying it. In a nutshell, we conclude that the former in question was the most important source of development and diffusion in reference to paremiological dictionaries written in the Persian language.

\section{References:}

1. Isfahani, Hamza ibn Hasan. Savair-al-amsal ala afala / compose by Saad. Beirut: Publisher: World of Books, 1988.

2. Amuli Mohamed, Nafaes-al-funun / compose by Abul Hasan Sherani. Tehran: Publisher: Intisharat $1.2 .3,1336$

3. Dehkhada / Amsal-va- hikam /Tehran: Publisher, 1338.

4. Dekhada, Lugatname / Dehkhada. Tehran: Publisher, Amir cabir, 1342.

5. Zamahshari. Mustaqsa in the Arab proverbs / Jarallah Mahmoud ibn Omar Zamakhshari. Scientific Book House. Beirut: 1408 AH -1987.

6. Yakut Hamawi, Literary Dictionary. 2 Part. Tehran: Sorush. 1423/2002/1391, p.

7. Khairidin Shams Pasha, Dictionary of Arabic Proverbs / Khairidin Shams Pasha. Center of Malik Faisal for Buhuth and Islamic Studies Riyath: First edition $1423 \backslash 2002$.

8. Rasheed ad-Din Vatvat, Lataif-al-amsal / by Habiba Danishomuz. Tehran: founder of Entisharat Miras Maktoob 1391 / 290 p.

\section{СРАВНИТЕЛЬНОЕ ИССЛЕДОВАНИЕ МЕТАФОРЫ "ЖИЗНЬ-ЭТО РАСТЕНИЕ" В КИТАЙСКИХ И АНГЛИЙСКИХ ХУ ДОЖЕСТВЕННЫХ ТЕКСТАХ}

\section{Ли Диди \\ Преподаватель Института Конфуция при СамГИИя Фазлиддинова Умеда студентка СамГИия}

\footnotetext{
Annotation: Meтафора - одно из самых основных явлений в человеческом языке. Изучение её имеет значение не только для языка, но и для исследования человеческого разума. Целью данной статьи является анализ метафорических выражений "жизнь-это растение" с когнитивной точки зрения, $m$. $e$. рассмотрение выражений с точки зрения теории конщептуальной метафоры. Проведено когнитивное сравнение английских и китайских конщептуальных метафор “жизнь-это растение". Несмотря на то, что они отмечены различными культурными корнями, основные понятия метафоры примерно одинаковы. Концептуальные метафоры в одной и той же системе имеют различные проявления в общепринятых высказываниях.
}

Key words : Ключевые слова: метафора, когнитивная лингвистика жизнь, растение, сравнение. 
“Метафора широко распространена в повседневной жизни, не только в языке, но и в мыслях и действиях. Наша обычная концептуальная система, в терминах которой мы одновременно думаем и действуем, по своей сути метафорична" (Lakoff\&Johnson, 1980). Метафоры настолько обычны, что мы используем их бессознательно и автоматически и часто не замечаем их (Lakoff\&Turner, 1989). Повседневный язык окрашен метафорами. Мы используем метафоры, когда нам трудно описать вещь или переживание (Mashak, S. etal. 2012).

Жизнь была бесконечной темой обсуждения с тех пор, как люди начали думать. Существует бесчисленное множество дискуссий на эту тему, начиная от философии, религии и литературных текстов. Люди говорят о жизни метафорически, как будто это разные типы вещей (Kövecses, 2005, 2010). В данной статье будет проведено сравнение концептуальных метафор “жизнь-это растение” в китайских и английских художественных текстах, свидетельствующее об универсальности концептуальной метафоры и выявлении ведущих к культуре расхождений. Чтобы гарантировать систематичность и типичность материалов, в основном будут использованы четыре части ресурсов: на китайском языке выбрана "Сон в красном тереме" (R), а на английском - четыре великие трагедии Шекспира: “Макбет” (M), “Король Лир” (L), “Гамлет" (H) и “Отелло” (O) используются, поскольку эти произведения являются классической литературой, и все они до сих пор влияют на языковые системы, к которым они принадлежат.

Концептуальная теория метафоры. Концептуальная теория метафор предлагает взгляд на то, как и когда люди находят смысл в жизни. В то время как смысл жизни может быть, трудно понять, метафора сравнивает жизнь с относительно более конкретной и структурированной концепцией. В обычном языке метафоры используются для того, чтобы сделать абстрактные понятия более конкретными. Поскольку когнитивные лингвисты (Lakoff \& Johnson, 1980) утверждают, что метафора относится к разуму, мозгу и телу, многие люди, знакомые с взглядом Лакоффа на метафору, ожидают, что “концептуальные метафоры” в значительной степени или в основном универсальны. Кажется, что несколько несвязанных языков могут иметь несколько общих концептуальных метафор для определенных понятий.

В своей основополагающей книге "Метафора, которой мы живем" (1980) Лакофф и Джонсон отметили поворотный момент в истории метафоры, определив ее как основной когнитивный инструмент, сознательно или бессознательно используемый местными языковыми сообществами для выражения самых обыденных концепций в их повседневной жизни. Для них "Метафора широко распространена в повседневной жизни, не только в языке, но и в мыслях и действиях. Наша обычная концептуальная система, в терминах которой мы одновременно думаем и действуем, по своей сути метафорична" (Lakoff \& Johnson, 1980). Другими словами, локус метафоры находится не в словах, а в нашем способе концептуализации и понимания одной области в терминах другой.

Обсуждения и результаты. Как в китайских, так и в английских художественных текстах легко найти выражения, которые концептуализируют человеческую жизнь как стадии развития растений и их частей в годичном цикле. Люди рассматриваются как растения, особенно та часть растения, которая разрастается, затем увядает и, в конце концов, приходит в упадок. Стандартный способ понимания и обсуждения жизненного цикла - это метафора, согласно которой люди являются растениями или частями растений, а человеческая жизнь соответствует жизненному циклу растения. Стадии развития растений и частей растений в их годичном цикле соответствуют стадиям жизни: бутон - молодости, полный лист зрелости, увядший лист - старости (Лакофф, Г. 1989). 
Хотя растение является своего рода формой жизни, более низкой, чем человек, оно все же образует саму систему, которая тесно связана с рассматриваемыми концептуальными метафорами. Растения относятся к многочисленным видам, среди которых деревья являются наиболее широко используемым исходным доменом. С одной стороны, естественная структура растения (корень, ветви, листья, цветы и т. д.) может быть использован в качестве исходной области концептуальной метафоры. С другой стороны, период роста растения (изменения состояний меняются вместе с изменениями времени; прорастают, цветут, плодоносят и т. д.) также может быть исходным доменом. Эти два вида исходных доменов принадлежат разным визуальным ангелам: первый статичен, а второй динамичен.

Далее мы выбираем несколько типичных выражений в поддержку нашего анализа сложной "метафоры растений ".

1. Со статической точки зрения: структура растения как домен источника.(1) 独根 孤种 $(\mathrm{R}, 4)$

(Единственный сын и наследник)

(2) 养出这样黑心不知道理下流种子来，也不管管！ $(R, 25)$

(Почему бы тебе не научить своего злобного сопляка вести себя прилично?)

(3) 看来两个人原本是一个心，但多生了枝叶。反弄成了两个心了。 $(\mathrm{R}, 29)$

(На самом деле, для начала их сердца были едины, но каждый из них был настолько сверхчувствителен, что их стремление быть ближе заканчивалось отчуждением)

（4）你这孩子素日最是个伶俐㙂明的，你又知道她有个呆根子，平白的哄他作什么? $(\mathrm{R}, 57)$

(Обычно ты такая разумная девушка, как ты могла так дразнить его, когда знаешь, насколько он доверчив?)

(5) It is myself I mean; in whom I know all the particulars of vice so grated. $(\mathrm{M}, 4)$

(Я разумел себя: во мне, я знаю,

Так, привились все облики порока.)

(6) With this there grows, In my most ill-compos'd affection such a stanch less avarice that... $(\mathrm{M}, 4)$

(Сверх того,

В моей дурной душе растёт такой избыток

Свирепой жадности, что...)

(7) This aavarice Sticks deeper, grows with more pernicious root than summer-seeing Lust, and it hath been the sword of our slain kings. (M, 3)

(Жадность

Зловреднее и глубже коренится,

Чем летний пыл страстей; то меч, сразивший

Немало государей.)

(8) You should not have believed me; for virtue cannot so inoculate our old stock but we shall relish it: I loved you not. $(\mathrm{H}, 3)$

(Напрасно вы мне верили; потому что, сколько ни прививать добродетель к нашему старому стволу, он все-таки в нас будет сказываться; я не любил вас.)

(9) Purpose is but the slave to memory, of violent birth, but poor validity; Which now, like fruit unripe, sticks on the tree, but fall unshaken when they mellow be. $(\mathrm{H}, 3)$

(Подвластны нашей памяти они:

Могуче их рожденье, хрупки дни; 
Так плод неспелый к древу прикреплен,

Но падает, когда созреет он.)

(10) Our bodies are our gardens, to the which our wills are gardeners... $(0,1)$

(Наши тела - это наши сады, для которых наши воли-садовники...)

Все эти метафорические выражения основаны на концептуальной метафоре “жизнь-это растение”. Их общее основание состоит в том, что все они используют структуру растений в качестве исходной области картографирования, описывая человеческие существа через соотнесение человеческих характеристик с конкретными частями растений.

В примерах (2) и (4) слова “下流种子”, “呆根子”являются традиционными высказываниями о человеческих качествах. В китайском языке слово «根» (корень), с одной стороны, достоверно представляет основную природу человеческой жизни или некоторые расширенные вещи; С другой стороны, это символизирует потомство, особенно потомство мужского пола. Эти два вида использования тесно связаны с природой деревьев, из которых корень является одним из наиболее важных, которые обычно необходимы. Первое употребление представлено в (4), в котором слово “根 "(корень) концептуализируется как радикальное значение для растений, Китайская традиционная модель мышления также интегрирована во второе общепринятое значение “根”. В отличие от китайского языка, трудно найти подобное употребление в английском языке, поскольку большинство англоязычных людей высоко ценят индивидуализм, отстаивают независимость и наслаждаются жизнью. Они придают большее значение счастью в своей собственной жизни. Сходство существует между двумя языками по отношению к первому употреблению, так как это употребление основано только на природе растений, а не на каком-либо влиянии культуры.

Естественно, что характеристики человеческого существа могут быть изменены, как части растений могут быть перемещены. В (5), слово «порок» привит; в (8) слово «добродетель» считается вещью, которую можно «привить». На основе объективации символов их можно перемещать. Возьмем, к примеру, “деревья”. Собственность деревьев - это те части, которые им принадлежат. Изменения в жизни осмысливаются как движения частей деревьев. "生生生"(ветви растут) в (3) и два глагола в (5), (8) являются типичными глаголами со значением движения. В (5) прививается "порок"; в (8) “добродетель" считается вещью, которую можно “привить”. Согласно приведенному выше анализу, можно сделать вывод, что в этих выражениях характеристики человеческой жизни воплощаются на частях растений. Наделение растений человеческими характеристиками является ярким доказательством рациональности и целесообразности создания сходства в метафорах. Изменения в жизни обычно реализуются с помощью профессиональных садоводческих глаголов.

В Библии есть знаменитая поговорка: “Для всего есть время, и время для каждой цели под небесами:

Время рождаться, и время сажать, и время вырывать то, что посажено". Это поговорка ярко описало человеческую жизнь с периодом роста растений как область источника. Поскольку исходная область-это период роста растения, который в значительной степени зависит от времени, эта часть метафоры растения имеет тесную связь с метафорой “жизнь-это день/год”, две концептуальные метафоры являются независимыми и тесно связанными. Существует множество метафорических выражений с периодом роста растения в качестве исходного домена, как в китайском, так и в английском языках.

(10)人世的荣枯，仕途的得失，终属难定。(R, 92) 
(“Процветание и разорение”, заметил Фэнг, “так же непредсказуемы, как успех или неудача в официальной карьере”.)

(11)...既不然，终有个落叶归根。(R, 100)

(...Так или иначе, “листья, которые падают, в конце концов, возвращаются к своему корню".)

(12)我所剩的东西也有限，等我死了做结果我的使用。( $R, 107)$

(“У меня больше ничего нет”, продолжала она, “то, что есть, может быть потрачено на мои похороны, всё, что остаётся, может уйти моим служанкам”.)

(13)一朝看尽红颜老，花落人亡两不知。(R, 28)

(День, когда весна взмывает ввысь и красота увядает, кто будет интересоваться упавшим цветком или мертвой душой?)

(14) 比如那花开时令人爱慕，谢时则增惆怅，所以倒是不开的好。(R, 31)

(То же самое относится и к цветам; они радуют людей, когда цветут, но так душераздирающе видеть, как они увядают, что было бы лучше, если бы они никогда не цвели.)

(15) I have begun to plant thee, and will labour to make thee full of growing.

There if I grow, the harvest is your own. (M, 1)

(Начав тебя растить, я позабочусь о пышном цвете.

Пусть в нем я возрасту, А вы снимите жатву.)

(16) I have liv'd long enough; my way of life is fall'n into the sear, the yellow leaf..(M, 5)

(Я жил достаточно: мой путь земной

Сошел под сень сухих и желтых листьев...)

(17) ...The expectancy and rose (Hamlet) of the fair state... (H, 3)

(...Цветок и надежда радостной державы...)

(18) When I have pluck'd the rose, I cannot give it vital growth again, it must wither: I'll smell it on the tree. $(0,5)$

(Срывая розу, Как я верну ей животворный рост?

Она увянет.

Надышусьцветущей.)

(19) But that myself should be the root and father of many kings. (M, 3)

(АябылназванкорнемиотцомВластителей)

(20) The canker galls the infants of the spring too oft before their buttons be disclos'd. And in the morn and liquid dew of youth Contagious blastments are most imminent. $(\mathrm{H}, 1)$

(Червь часто точит первенцев весны,

Пока еще их не раскрылись почки,

И в утро юности, в росистой мгле,

Тлетворные опасны дуновенья.)

(21) He could not die when the trees were green.

For he loves the time too well. (John Clare: The dying Child)

(Он не мог умереть, когда деревья были зелеными.

Потому что он слишком любит это время.)

В растительных метафорах жизни период роста растения представлен ярко и отчетливо: от укоренения и прорастания до цветения и плодоношения, а затем оседания опадающих листьев на их корнях. Через различные свойства растений проявляются различные характеристики и состояния различных стадий жизни, что является достоинством этой метафоры.

В примерах (13), (14), (17), (18), слово “花”(цветок) появляется неоднократно. В период роста растения период цветения является наиболее благополучной стадией развития растения, как с точки зрения внешнего вида, так и с точки зрения жизнеспособности. Растение на этой стадии полно жизненной силы, как и люди на 
стадии молодости. Слово “花”(цветок) используется для обозначения молодого этапа жизни. В западном обществе разные цветы имеют разное значение, и эта культура цветов постепенно внедряется в Китае в последние годы. Кроме символических растений разных периодов роста, в этой части встречаются также символические цвета. В (21) зеленый цвет используется для обозначения молодости человеческой жизни, так как растение обычно бывает зеленым на своей молодой стадии. В примере (11) и (16) появляются “根”(корень) и“叶”(лист). Мы рассматриваем их не как части растения, а как воплощение определенной стадии периода роста растения, т. е. стадии старости.

В примере (10), человеческая жизнь распространяется на сферу всего мира. “荣枯” (цветение и увядание), которое первоначально означает различные стадии развития растений, используется для описания различных состояний человеческой жизнисостояния мира. В примере (12), слово “结果”(результат/итог) используется в другом значении. Это слово первоначально было садоводческим термином, означающим "плодоносить". Поскольку плодоношение обычно является последней стадией жизни растения, поэтому оно отображает смысл окончания на целевую область жизни. В настоящее время этот смысл “конца жизни ” широко принят и закреплен. В то время, трудно найти подобное употребление в английском аналоге (fruit). Пример (20) - это сочетание концептуальных метафор “жизнь-это год” и “жизнь-это растение”. В примере (19) структура растения, период роста растения и разброс времени каждый из них блестит более ярко в другой компании.

В этой статье автор подробно развивает одну из важных концептуальных метафор жизни, а именно: “жизнь - это растение”. Эта метафора происходит от метафоры “люди-растения", и человеческая жизнь соответствует жизненному циклу растения. В китайском и английском литературных текстах существует множество метафор, и результаты показывают, что концептуальные метафоры в одной и той же системе имеют различные проявления в общепринятых высказываниях, а некоторые выражения в английском и китайском языках схожи.

\section{Литературы:}

1. Kövecses, Z. 2005. Metaphor in culture: Universality and variation. New York, NY: Cambridge University Press.

2. Kövecses, Z. 2010. Metaphor: A practical introduction. New York, NY: Oxford University Press.

3. Lakoff, G., \& Johnson, M. 1980. Metaphors we live by. Chicago and London: University of Chicago Press.

4. Lakoff, G \& Turner, M. 1989. More than cool reason. Chicago: University of Chicago Press.

5. Lakoff, G. 1989, Women, fire, and dangerous thing: A field guide to poetic metaphor. Chicago: University of Chicago Press.

6. Pirzad Mashak, S., Pazhakh, A. \& Hayati, A. 2012. A comparative study on basic emotion conceptual metaphors in English and Persian literary texts. International Education Studies, 5, $1,200-20$.

\section{Интернет ресурсы:}

1. Шекспир, Гамлет. Принц Датский [Электронный ресурс]. — https://онлайнчитать.рф/шекспир-гамлет/

2. Шекспир, Отелло [Электронный ресурс]. — https://онлайн-читать.pф/шекспир-отелло/

3. Шекспир, Король Лир [Электронный ресурс]. - https://онлайн-читать.pф/шекспиркороль-лир/

4. Шекспир, Макбет [Электронный ресурс]. — https://онлайн-читать.pф/шекспир-макбет/ 


\section{ОНОРЕ ДЕ БАЛЬЗАКНИНГ ТЕОДОР ДРАЙЗЕР ИЖОДИГА ТАЪСИРИ}

\section{Қаршибаева Улжан Давировна Филология фанлари доктори, СамдЧТИ профессори Алиева Гулзода Тулқиновна СамДчТИ ўқитувчиси E-mail : $\underline{\text { k.uljan70@mail.ru }}$}

Annotation: This article is about the similarities between the protagonists of the works of the famous English writer T. Dreyzer and the great French realist 0 . de Balzac. This is the type of hero who leads his own success with all his might
Key words : realism, social, social, psychological, emotional, illusion

Теодор Драйзер XIX-XX аср оралиғидаги АҚШнинг таниқли ёзувчисидир. Айнан ўша пайтда Америка хаётида нафақат ижтимоий жихатларга таъсир кўрсатадиган катта ўзгаришлар юз берган. Тадқиқотчиларнинг фикрига кўра, Драйзер 0. де Бальзак, Л.Н.Толстой, Ф.М.Достаевский, А.Дюма, Э.Золя, М.Твеннинг анъаналарига таянган “Шимолий Америкадаги ўша даврнинг энг буюк реалист ёзувчиларидан бири" бўлган [5, p.74]. Унинг асарида ўтмишдаги энг яхши ёзувчилар ва мутафаккирларнинг ютуқлари акс этган. Реалист ёзувчи Драйзер ўз ижодида шахснинг жамиятдаги ўрни хақидаги саволни кўтариб чиқади, бадиий жихатдан шахс ва жамиятнинг шахсиятни сиқиб чиқариш муаммосини ўрганади, инсоният жамиятда шахснинг мавжудлигининг турли хил психологик ва ижтимоий жихатларини батафсил ўрганади.

Драйзернинг “Хохишлар трилогияси”да йўқотилган иллюзиялар мавзуси бош қахрамонФрэнк Каупервуд образи билан боғлиқ, у бутун умр шон-шухрат ва бойликка интилади, бироқ хеч бири унга асл қувончни олиб келмайди.

Шунингдек, Бальзак ва Драйзер романлари қахрамонлари хулқига шахарнинг таъсири сабабларини тадқиқ қилиши ва уларнинг эмоционал холатларига бўлган алохида қизиқиши бирлаштирган. Айнан Бальзак томонидан Париж хаёти тасвирлангани Драйзерда ўчмас из қолдирди ва унинг асарларида хам ўз аксини топди («The reading that did affect him... was Balzac, who, in his massive fictions about the life of Paris, gave Dreiser a new sense of the cities» [4, c. 1879]).

Ғарб адабиётининг икки буюк ёзувчилари ижодига назар ташласа Бальзак ва Драйзер асарларида умумий элементлар мавжудлигини таъкидлаш мумкин. Бу бутун кучи билан ўз муваффақиятга йўл очадиган қахрамон типидир. Бальзакда персонажларни яратиш камбағаллик ва бойлик ўртасида тиниқ контраст пайдо бўлган вақтда, икки революция билан туғилган, пул ва буюмлар кучи одамдан, унинг ички дунёсидан устун қўйилган давр рухи билан боғлиқ эди. Хеч нарсага қарамасдан, одобахлоқ қоидалари билан хам хисоблашмасдан ўзи учун юқорига йўл очишга интиладиган қахрамонлар пайдо бўлган. "Горио ота"да Растиньяк билан ахлоқий томондан уларга замондош жамият мавзусига оид сухбатларидан бирида жаноб Вотрен китобхонлар кўз ўнгида шундай гавдаланади. Унинг фикрига кўра, "ростгўй одам хаммага душман" [1, c. 111], шунинг учун “ўзини қонунданда устун қуйган" сотқин, иккиюзламачи, хасадгўй одамлар қуршовида, хар доим ўз хохишларини амалга ошириш учун “замбаракли ядро қуроли ёки ўлатдек” [1, с. 111] таъсир қилиши керак.

Унинг бой ва камбағаллар ўртасида қочиб бўлмас тубсизликнинг ўсишини; хамда бутун Америка миллий характерини ва “америка орзу"си миллий ғоясини иғвогарлик қилган монополиянинг жадал ўсиши билан характерланган давридаги америка хаёти хусусиятларига кўра бунақа типлар Драйзерга яқин бўлиб чиқди. 
Бироқ, Бальзак ва Драйзер қахрамонларининг муваффақияти йўлида ўзига ва шахсий хохишларига ишончи йўқолади ва умидсизлик пайдо бўлади. Бальзакда йўқотилган иллюзиялар мавзуси ўз аксини шу номли романи (“Йўқотилган иллюзиялар”, 1837 йил [2])да Люсьен ва Шардон тақдирлари мисолида намоён бўлади. Буюк асарларни яратишни орзу қилган қобилиятли шоир, мураббийлари маслахатига кўра Парижга келади, у ерда буржуа жамиятнинг очкўз, важохатли, иккиюзламачи вакиллар билан курашга чидай олмайди, бунинг натижасида Люсьен ўзига ишончини ва ёрқин адабий келажак хақидаги орзусини амалга ошириш умидини йўқотади. Унинг дўсти, мехнатсевар ва қобилиятли Давид Сешар хам қоғоз ишлаб чиқаришни мукаммаллаштириш хақидаги ўйларини амалга оширолмасдан ўз иллюзияларини йўқотади. Икки қахрамон хам қаттиқ қонунлар, сотқинлик ва пулнинг чегарасиз хукмронлиги билан курашишга қодир эмас эди.

Урбанистик мавзуга Теодор Драйзер хам ўз асарларида мурожаат қилади. Унинг хар бир романи бош қахрамони эркак ёки аёл бахт, шон-шухрат ва кўп пул ишлаб топишга интилиб, туғилган кичик шахарларини тарк этиб Чикаго, Нью-Йорк ва Лондон каби мегаполисларга интилишган. Масалан, “Керри опа”даги Каролина Мибер ва Дженни Герхардт каби роман қахрамонлари, ўз хаётини Чикагода тузишга харакат қилишади, “Америка фожиаси”даги Клайд Гриффитс ўз амакисининг фойдали таклифига кўра Нью-Йоркга кўчади ва у ерда, унинг муваффақият ва парокандалик тарихи ривожланади. Лекин энг ёрқин карьерани “Хохишлар трилогияси” романи бош қахрамони Фрэнк Каупервуд қилишга муваффақ бўлади. Ўз хаётида бу молиявий магнат Филадельфия, Чикаго ва Лондон каби катта шахарларни забт этган эди ва хар бир шахарда уни ўша жой кайфияти билан тўғри келадиган ажойиб воқеалар кутаётган эди. Консерватив, ғамгин Филадельфияда Фрэнк ўзини етарлича таниқли, омадли ва бахтли хис қилмаган ва хар доим ўзгаришлар керак деган фикрда бўлган; прогрессив, рухлантирувчи Чикагода унинг карьераси имкониятларига кўра баландда бўлган ва максимум даражада бор куч-қудратини ишлатган, жимжит, тинчлантирувчи Лондон табиати қуршовида қахрамон хақиқий хаёт қадрини англаган ва ўз тинчлигига эришган.

Париж Бальзак романларида хашамат ва қашшоқликда бир-бирига яқин шахар бўлиб гавдаланади ва бир вақтнинг ўзида бу шон-шухрат ва муваффақиятга эришиш учун уруш бўлган жанг майдони эди. Шахар икки қаватли кўрсатилган, бир тарафдан у буржуа цивилизациясининг қурилаётган бино “улуғвор ташқи кўриниш”га эга, бошқа томондан эса у “жамият ахлатлари" деб аталганганлар яшайдиган "қоронғи, яширин бурчаклар"га эга эди [3, с. 163]. Шунинг учун Парижда истиқомат қилувчи одамлар шухратпараст, ўзига ишонган, мақсадга интилувчан шахслар ва шу билан бирга улар яшаётган маконни белгилаб берган, ушбу жамиятдаги инсонлар эса ролларни уйнаётган ёлғончи, хиёнаткор, номуссиз аблахларга бўлинган. Шахар одамларнинг кайфиятига таъсир кўрсатишга қодир эди ("энг бепарво одам хам бу ерга тушиб қолиб ғамгин одамга айланади” [1, с. 34]), фикрлар йўналишини ўзгартиришга (“Нев-СентЖеневьев кўчаси... қоронғи рангларни ва жиддий фикрларни талаб қиладиган бу ибора учун ниқоб сифатида хизмат қилишга энг лойиғи эди" [1, с. 34]), жабр-зулм қилишга ("Париж шахри атрофларидаги кулбалар...бадбахтлар... Пойтахт қашшоқ ва қўрқинчлилиги билан салобатли эди...” [1, с. 315]).

Шундай қилиб, икки ёзувчи ижодининг қиёсий тахлили бир қатор параллелларни аниқлайди. “Инсон комедияси”ни яратишда Бальзак риоя қилган принциплардан унинг издоши Драйзер хам мохирона фойдаланган. Бу ерда, табиат ўзининг қонунларига хар қандай тирик жонзотни бўйсундирган, хамда натурализм билан чегарадош бўлган борлиқнинг реалистик тасвирланиши бўлган жойда, инсоният жамиятини хайвонот оламига ўхшатганлиги кўриш мумкин. 
Адабиётлар:

1. Бальзак О. Собрание сочинений / Под общей редакцией Н. Балашова. - М.: Худож. лит. $-1982 .-1025$ c.

2. Бальзак О. Утраченные иллюзии / Пер. Конник М.В. - М.: Правда. - 1989. - 492 с.

3. Муравьева Н.И. Оноре де Бальзак. Очерк творчества. - М.: Просвещение. - 1985. - 163 с.

4. American Literature. The Makers and the Making. Book D, 1914 to the Present. - N. Y.: St.Martins Press. - 1973. - p. 1196 - 2970.

4. Reedy W.M. "Sister Carrie": A Strangely Strong Novel in a Queer Milieu// Pizer Donald. Critical Essays on T.Dreiser.- Boston, Massachusetts, 1981. P. 74.

\section{БЕШИНЧИ НУТҚ ФАОЛИЯТИ ТУРИ БЎЛГАН ТАРЖИМА ХАҚИДА}

\section{Ўзбекистон Давлат Жахон Тиллари Университети профессори}

Чет тилларни ўрганишга бўлган эхтиёж тарихи узоқ-узоқларга бориб тақалади. Бироқ бу фаолият, яъни чет тилни ўргатиш фанга айланиш жараёнида бир неча босқичларни босиб ўтишига тўғри келди. Шу жараёнларни онгли-онгсиз ўрганиш натижасида 20 асрга келиб асосан тўртта нутқ фаолияти тури қайд қилинди: чет тилда гапириш, чет тилдаги гапни тинглаб тушуниш, чет тилда ёзиш (ёзув эмас) ва чет тилда ўқиш. Ана шу тўртала нутқ фаолиятига ўргатиш бўйича минглаб турли туман назариялар, бир-биридан кўчириш ва “таржима қилиш”лар, методик ўқув адабиётлари яратилди ва улар асосида чет тилларни ўргатиш иши деярли стихияли давом этиб келмоқда. Бироқ назарияни қанчалик ривожлантирмайлик ва уни ўрганмайлик, айниқса чет тилда гапириш масаласида муаммолар кўпайгандан-кўпайиб бормоқда. Шу саъй-харакатларни жиддий бир йўсинга йўналитириш учун Европа CHEFR талаблари хам ишлаб чиқилди.

Маълумки, нутқ нафақат лингвистик-лисоний, балки бу даставвал психологик ва айни бир пайтда содир бўладиган нейрофизиологик жараёндир. Тил ва тафаккур дилеммасида албатта дастлаб инсон миясида пайдо бўладиган хилқат- фикр. Фикрлаш эса фақат она тилида амалга ошади. Она тилида пайдо бўлган ана шу фикримизни чет тилда айтиш жараёнида дастлабки содир бўлаётган нейропсихологик жараён - таржима, аниқроқ айтадиган бўлсак, онг остида содир бўладиган синхрон (симултан) таржимадир. Ана шу фаолият дидактика ва методика илмида жиддий уррганилмаса ва таълимда бўлғуси чет тил мутахассисига ўргатилмаса, унинг овоз чиқариб чет тилда гапириши ёки ўз фикрини ёзма шаклда чет тил матнига айлатириши хеч қачон қиёмига етмайдиган чаласавод фаолият натижаси бўлиб қолаверади. . Схемага солинган бу фаолият манзараси: фбикр - (синхрон) таржима (оғзаки ёки ёзма) нутқ шаклида тасвирланиши мумкин. Биз ирод қиладиган нутқимиз сифати шаклан ва мазмунан ана шу (синхрон хзолда содир бўлаётган) таржиманинг савиясига бевосита боғлиқдир.

Бу масалада тайёрланган монографик тадқиқотимизнинг тезиси сифатида ушбу фикрларни ўз оғзаки ва ёзма таржимонлик фаолиятимиз ва бошқа синхронист таржимонларнинг фаолияти тахлилида илгари сурмоқдамиз. Аммо хозир ана шу таржима жараёнининг бир қисми хисобланган амалий таржимани фан сифатида ўқитилаётгани учун бажарилаётган илмий-услубий изланиш ва тадқиқотлардан бир шингил сифатида тақдим этилган бир-икки қўлланма хақида мухтасар фикр билдирмоқчимиз. Фан сифатида амалий таржиманинг чет тиллар бўйича тайёрланажак мутахассислар ўрганаётган умумлисоний фанлар рўйхатига киритилиши ижобий холат, бироқ бу фанга ажратилган ўқув вақт (соатлар)и хажми - 
жуда кам. Бу фан хозир иккинчи курсда фақат бир семестр ўқитилиши етарли эмас; уни барча 8 семестр давомида хафатсига 4 соатдан ўқитсаккина, битирувчини (амалий) таржимага тайёрлай оламиз. Аммо афсуски, нафақат битирувчи бакалавр даржали мутахассис, балки бакалаврларни ўқитаётган мутахассис чет тил ўқитувчисининг 80 фоизи тўртала анъанавий нутқ фаолиятлари бўйича чет тилда (турли савияда) гапира, тушуна, ўқий ва ёза олса хам, бироқ қониқарли таржима қила олмайди (Бу масалда биз бир хил матнни 8 кишига бўлиб бериб саккиз хил вариант ва сифатда жавоб олдик ва буни ўзингиз хам методик эксперимент ўтказиб кўришингиз мумкин). Амалий таржима қилаётган таржимоннинг фаолияти сифатига албатта уларнинг гапириш, тинглаб-тушуниш, ўқиш ва ёзиш каби нутқ фаолият турларида эришган ютуқлари хам маълум замин яратади.

Кундалик методик-дидактик фаолият давомида хар биримиз шу “Амалий таржима” фанини ўқитмоқдамиз, бироқ дидактик манзара чатоқ: бу фан бўйича махсус ўзбек талабалари учун конкрет тиллар материалди яратилган ўқув адабиётлари тақчил, махсус таълим стандарти талабга жавоб бермайди. Ўқитувчиларнинг ккўпчилиги бу фанни ўқитишга мутахассислашмаган. Таржимага қўйиладиган талаблар, таржима учун бериладиган савол ва топшириқлар турли хил ва кўпинча нопрофессионал. Натижада турли устозларнинг талабалари "турлича мақомга йўрғалашмоқда". Хатто мамлакат нашриётларида чоп этилаётган айрим номдор чет тилчи таржимонларнинг амалий таржималари кўнгил айнитиш даражасида дунё юзини кўрмоқда. Демак дидактикада муаммо пайдо бўлмоқда: махсус ўқув адабиётлари яратилмоғи керак, улар маълум апробациядан ўтказилмоғи даркор.

Умуман олганда таржимашунослик илмининг ўзбекона фундаментини Ғайбулла Саломов яратиб бергандан сўнг қилинадиган долзарб ишлардан бири бўлган конкрет тиллар жуфтлиги материалида махсус ўқув адабиётлари яратилмоғи шу куннинг мухим вазифаларидан биридир. Шу йўналишда қўйилган дастлабки қадамлар хақида қуйидаги икки тадқиқот мисолида тўхталишни лозим топдик.

Шундай ишлардан бири Наманган давлат университети доценти, филология фанлари номзоди таржимашунос олим Зохиджон Содиқовнинг "Немис тилидан амалий таржима” қўлланмаси хисобланади. 2019 йилда чоп этилган мазкур ўкув кулланмада мамлакатимиз олий таълим тизимида чет тиллар буйича янги авлод укув адабиётларини яратиш, бу борада талабаларимиз учун махсус ўқув адабиётлари тайёрлаш вазифаси алохдда долзарб масала. Наманган давлат университета Немис ва француз тиллари кафедраси доценти, филология фанлари номзоди Зохиджон Содиқовнинг “Амалий таржима” (немис-ўзбек тиллари) мавзусида тайёрланган ўкув қўлланмаси айнан ана шу муаммони ечишга каратилганлиги билан хам мухим ахамият касб этади. Мазкур ўқув қўлланмада немис тилидан ўзбек тилига таржима килишнинг асосий амалий масалалари ёритилган. Китоб 16 та мавзуни қамраб олган бўлиб, улар немис тили морфологияси ва синтаксисисининг энг асосий бирликлари таржимаси мисол ва машқларда ёритилган. 3.Содиқов муаммонинг энг зарурий бўлган грамматик томонларини ёритар экан, бунда дастлаб уларнинг хар икки тилдаги ўхшаш ва фарқ қилувчи жихатларини тахлил қилган, контрастив лингвистика асносида хар икки тилдаги муштарак ва ўзига хос томонларни кўрсатиб берган. Сўнгра қўлланмада кўтарилган хар бир назарий масалага оид амалий машқлар берган. Бундан ташқари ишнинг амалий томонини янада мустакхамлаш учун хар бир мавзуга бир қатор тестлар тузилганки, бу олинган билимларни янада мустахкамлашга катта ёрдам беради. Шуни алохида таъкидлаш лозимки, ушбу ўқув қўлланмадан нафақат амалий таржима муаммолари бўйича, балки лексикология, стилистика хамда таржима назарияси ва амалиёти фанларини ўрганиш ва ўргатишда қўшимча манба сифатида хам фойдаланиш мумкин. Агар қўлланмада қўйилган саволларнинг жавоби китоб оркасида калит сифатида берилганда, уни мустаъқил таълимда хам қўллаш мумкин бўлар эди. 
Яна бир тавсияки, мустақил амалий таржима кўникма ва малакаларини шакллантириш ва ривожлантириш мақсадида қўлланманинг нихоясида маълум хажмда махсус қисқа хажмли матнлар тўпламини хам илова қилиш мақсадга мувофиқ деб биламиз. Умуман бу қўлланмани нафақат Наманган, балки республика университетлари учун зарур ўқув адабиёти бўладиган дарслик сифатида кўп нусхада чоп этмоқ даркор.

Шу йўналишда яратилган яна бир “Таржима назарияси ва амалиёти” номли ўқув адабиётини Урганч давлат университети доценти, филология фанлари номзоди, таржимашунос олим Зохиджон Жуманиёзов хам яратиб, уни 2019 йилда чоп эттирган. Бу фан асосан 4-босқич талабаларига мўлжалланган. Унда таржима тарихи, назарияси ва амалиётининг асосий масалалари фактик мисоллар ёрдамида ёритилган. Бу китобни хам республиканинг барча немисшунос талабалари ва магистрантлари учун кўп ададда нашр қилиш керак. Бу иккала қўлланма бир-бирини тўлдирувчи ўқув адабиёти бўлибди.

Шу йўналишдаги ишлар сирасига икки тилли катта хажмли таржима луғатларини яратиш хам кирадики, бу сохада хам хайрли ишлар бошланган. Жумладан Бухоро давлат университети немис тили кафедраси жамоаси 2018 йилда тайёрлаб чоп эттирган 80 (саксон) минг сўздан иборат катта “Немисча-ўзбекча луғат" немисчаўзбекча лексикография тарихида энг салмоқли асар бўлдики, бундай изланишларни давом эттириш чет тил мутахассисларини тайёрлашдаги бешинчи нутқ фаолияти хисобланувчи таржима қилиш бўйича шакллантириладиган кўникма, малака ва лаёқат (компетенция)ларни ривожлантиради ва бундан кенг миқёсдаги маънавий соха - таржимачилик амалиёти фақат манфаат кўради, бажарилаётган амалий таржималарга эса сон ва сифат кира бошлайди.

\section{Адабиётлар:}

1. Содиқов 3. Амалий таржима (немис-ўзбек тилларида). Наманган 2019.

2. Саломов Ғ. Таржима назарияси асослари. Т.,1982.

3. Саломов Ғ. Таржима назариясига кириш. Т. 1978

4. Жуманиёзов 3. Таржима назарияси ва амалиёти. Тошкент 2019.

\section{АБУ РАЙХОН БЕРУНИЙНИНГ ЛИНГВОФАЛСАФИЙ ҚАРАШЛАРИ ТАХЛИЛИ}

\section{Хандамова Маърифат Акрамовна Самарқанд Давлат Чет Тиллар Институти доценти}

Annotation: The article analyzes the lingo-philosophical views of Abu Rayhan Beruni in the works "India", "Osor ul-Baqiya". It describes the peculiarities of Arabic and ancient Indian languages. It is impossible to imagine a society without language, the philosophy of language deals with the philosophical observation of its origin, essence, influence on human society, its place, role and significance in the stages of human civilization.
Key words : Beruni, language, morphology, syntax, Sanskrit

Тил - миллатнинг маънавий бойлигидир. Тил нафақат муаммола воситаси балки халқнинг маданияти, урф-одати, унинг турмуш тарзи, тарихидир. Турли халқларнинг тилларига хурмат эса ўз навбатида ўзаро тушунишни, мулоқотларга имконият яратади. Тилсиз жамиятни тасаввур этиб бўлмайди, унинг келиб чиқиши, мохияти, кишилик жамиятига таъсири инсоният цивлизацияси босқичларидаги ўрни, роли, ахамиятини фалсафий мушохада қилиш билан тил фалсафаси шуғулланади. Тилларнинг вужудга келиши, ривожи ва ахамияти хақида қадимдан хинд ва юнон файласуфлари фикр юритганлар. Барча тилларни тан олиш ва хурмат қилиш тинчликнинг бирдан бир кафолатидир. Шу сабабли хам хар бир халқ ўз тили сақланиб 
қолиши учун харакат қилади. Олимлар инсоният тарихида 9000 мингдан ортиқ тил йўқ бўлиб кетганини айтишади. Нафақат босиб олинган худудлардаги халқларнинг тиллари, балки фотихларнинг тиллари хам йўқолиб кетгани тарихдан маълум. Бу борада қадимги юнон, оромий, лотин, санскрит, ведий, ассурий, қадимги форс тилларини мисол сифатида келтириш мумкин.

Ўзбек тилига давлат тили мақоми берилганининг ўттиз йиллигига бағишланган тантанали маросимдаги нутқида Президент Шавкат Мирзиёев тил хақида қуйидаги фикрларни билдиган эди: “Доно халқимиз “Тил билган - эл билади” дейди. Бу борада буюк боболаримиз ибрат ва намуна кўрсатганлар. Хусусан, Мусо Хоразмий, Абу Райхон Беруний, Абу Али Ибн Сино, Имом Бухорий, Ахмад Фарғоний, Махмуд Замахшарий, Алишер Навоий каби улуғ аждодларимиз ўнлаб тилларни пухта билганлари учун хам жахон илм-фанининг юксак чўққиларини забт этганлар" [1].

Қомусий олим Абу Райхон Беруний хам ўзининг асарларида бу хақида чуқур ва илмий қарашларни илгари сурган. Беруний ўзининг "Хиндистон”, асарида мусулмонлар билан хиндларнинг урф-одатлари ўртасидаги фарқларни тахлил қилиб, улар географик шароитларга боғлиқ деган фикрни илгари сурди, географик омилнинг ролини тахлил қилишни давом эттириб, хатто тилларнинг турличалиги хам географик шароитларга боғлиқ деб қаради. “Осор ул-боқия” асарида эса “Тилларнинг турлича бўлишига сабаб одамларнинг гурухларга ажралиб кетиши, бир-бирларидан узоқ туриши"дир [2].

Беруний учун хинд тиллари, санскрит, адабий тиллар - арабча, форсча, ва унинг ўз она тили хоразмийчага нисбатан ўз тузилишига нисбатан жуда катта фарқ қиладиган тиллар эди. Аллома “Хиндистон” асарида хинд тилининг фонетикасини ўзлаштириши оғир кечганлигига алоқида урғу берганлиги унинг қуйидаги фикрларида кўринади: “Уларнинг тилидаги баъзи харфлар араб ва форс тилларига тегишли товушларга тўғри келмайдиган ва ўхшамайдиган харфлардан таркиб топган; хатто, тил ва оғзимиз у харфларни ўз жойидан чиқариб айтолмайди; қулоқларимиз уларнинг ўхшаш ва тенгдошларидан ажратиб эшитолмайди ва қўлларимиз у харфларни худди ўзидек қилиб ёзолмайди; натижада, уларнинг айрим сўзларини бизнинг хатимиз билан кўрсатиш қийинлашади... Хиндларнинг тилларида, бошқа халқлар тилларида қатор келгани сингари икки ва уч ундош харф кетма-кет келади. Сухбатдошларимиз у харфларни “унлиси яширин харфлар” деб атайдилар. Кўпгина сўз ва исмлар сукун [ундош харф] билан бошланганидан, уларни талаффуз қилиш бизга қийин бўлади. Хиндлар тил ва луғатларидаги шу хусусият билан бошқалар олдида фахрланадилар; хақиқатда эса бу, тил ва луғат учун айб саналади" [3; 32-33]. Бизнинг фикримизча, хинд тилининг диалектларининг кўплиги, тилларида дунё манзарасининг акс этиши кенгроқ ва мукаммал деб айтишимиз мумкин.

Беруний тилларни қиёсий тахлил қилиш натижасида қуйидаги фикрга келган: “нуқта ва белгиларни ўзгартириб, машхур ёки сунъий белгиларни қўйиб, ўша луғатни аниқлашга мажбур бўламиз” - деб таъкидлаган. Шунингдек фикрини давом эттириб: "агар нусха кўчирувчилар тилларга эътибор беришмаса, тузатиш ва солиштиришда бепарволик қилишса, сўнг қилинган мехнат бекор бўлиб, китоб бир-икки марта кўчириб ёзишда бузилади ва у икки халқ [хинд ва мусулмон] орасига кирган ёки улар орасидан чиққан киши билолмайдиган янги бир тилга айланиб кетади” [3; 32-33].

Беруний хинд тилларини оддий халқ ишлатадиган тилга фозиллар ишлатадиган сарф [морфология], иштиқоқ [этимология], нахв [синтаксис] ва балоғатнинг нозик қоидаларига асосланган соф тилга бўлган. Беруний “соф тил” деб бу ерда, шубхасиз, санскрит тилини назарда тутаяпди, “оддий халқ” ... “тили” деб - Хиндистоннинг Махмуд Ғазнавий томонидан забт этилган ерларининг, яъни асосан, Ғарбий Панжобнинг махаллий тилларини назарда тутаяпди. Лекин Беруний "Хиндистон" асарининг бирор жойида “санскрит” деган иборани ишлатмаган. У оддий халқ 
сўзлашадиган оғзаки тил билан ёзма адабиёт тили - санскритни бир тилнинг икки стилистик - услубий шакллари деб қараган, одатда ўрта аср хинд грамматиклари хам шундай қараганлар.

Тарихдан маълумки, босқинчилик урушлари натижасида халқларнинг тиллари бир-бирларига таъсир кўрсатган. Олимнинг таъкидлашича, кўпинча тиллари бошқа халқ у сўзларни келиштириб айта олмай қабул қилади, натижада ўша исмларнинг маънолари ўзгариб, шу холича юнонлар одати сингари, ўз тилларига киради. Масалан “тош” сўзи асли туркча сўз бўлиб, “шош” кўринишини олган. Тошканд - “тошли қишлоқ” демакдир [3; 226].

Ёки олим араб тилининг хам хусусиятларига тўхталиб, “араблар [чет тилидаги] номларни араблаштириб, асл талаффузни бузганларидек, бир тил бошқа тилдаги харфлар товушини ўз талаффузини енгиллаштирадиган товушларга алмаштиради. Масалан, уларнинг китобларида Пушанг сўзи Фушанждир [3; 227].

Берунийнинг кўп тилларни билиши хақида хам олимлар орасида кўпгина қарашлар мавжуд эди. Немис олими Э.Захау Беруний юнон ва сурёний тилларини билмаган ва фақат арабча таржималаридан фойдаланган, деб қатъий айтган эди. Лекин европалик олимлар М.Мейерхоф, Ф.Кренковларнинг олимнинг янги топилган асарларининг тадқиқотларидан маълум бўлдики, Беруний нафақат у икки тилни, балки, қадимги яхудий тилини хам мукаммал билган. И.Ю.Крачковский бу фикрни янги материаллар ва қўшимча мулохазалар билан маъқуллаган [4; 586-587] эди.

Юқоридаги фикрлардан келиб чиқиб, Берунийнинг тиллар хақидаги фикрмулоқазалари замонавий линго-фалсафага ва ушбу сохаларни ривожлантиришга мухим таъсир кўрсатади.

\section{Адабиётлар:}

1. Мирзиёев Ш.М. Ўзбек тилига давлат тили мақоми берилганининг ўттиз йиллигига бағишланган тантанали маросимдаги нутқи. Халқ сўзи газетаси / 2019 йил, 19 октябр.

2. Абу Райхон Беруний. Танланган асарлар I том. Т.: “Фан”, 1968, 16-17 бетлар.

3. Абу Райхон Беруний. Танланган асарлар II том. Т.: “Фан”, 1965, 32-33 бетлар.

4. Крачковский И.Ю. Избранные сочинения, том II. Москва-Ленинград, 1956, стр. 586.

\section{Е. Э. БЕРТЕЛЬС ТАСАВВУФНИНГ АСОСИЙ УНСУРЛАРИ ХАҚИДА}

\section{Туробов Бекпулат Нусратуллаевич СамДЧТИ Илмий тадқиқотлар, инновациялар ва илмий педагогик кадрлар тайёрлаш бўлим бошлиғи}

Annotation: This article deals with the main stages of human spiritual development in mysticism in the work of the orientalist E.E. Bertels, the epistemological issues of the psychological research of the first theorists of Sufism, the basic principles of mysticism.
Key words : Sufism, asceticism, scholastic philosophy, honest, impure, Junaid Baghdadi, Sufism, cloak, sacrifice, epistemology, asceticism, cheat.

Тасавуфнинг ғояларининг тадрижий ривожланиши узоқ даврни ўз ичига олади. У зохидлик амалиётидан схоластик фалсафа йўлини босиб ўтди. Тасаввуфнинг асосий қонун-қоидалари IX асрдан бошлаб тахминан XII асрнинг бошларигача ўзига хос кўринишга эга бўлди. Шарқшунос олим Е.Е. Бертельс бундай мураккабликнинг сабабини тасаввуф турли оқимларининг ғоят ранг-баранглиги ва фарқида деб билди. Е.Э. Бертельснинг хаққоний таъкидлашича, хеч қачон яхлит тасаввуф бўлмаган. Шунинг учун барча оқимлар учун у ёки бу даражада муштарак холатларни аниқлаш 
мумкин. Бу хам хақиқий манзарани тахминан акс эттирувчи умумлашмалардан иборат бўлади.[1;61].

Тасаввуфда инсон маънавий камолотининг асосий босқичлари кўрсатилган. Биринчи босқич шариат бўлиб, унга биноан илохий қонунларнинг сўзсиз бажарилиши шарт. Е.Э.Бертельс бу тор маънодаги тасаввуфга кирмайди, деб хисоблайди, чунки хар бир мусулмон унга амал қилишга мажбур. Сўфий хам шариат қонун-қоидаларни бажариши керак, чунки уларга амал қилмасдан кейинги босқичга ўтиш мумкин эмас. Исломнинг асосий ақидалари эгаллангандан кейин инсон олдида тариқат («йўл») очилиши мумкин. Тариқат боши, биринчи манзил, одатда, тавба («қилмишига пушаймон бўлиш»)дир. Тасаввуфда бу тушунча янада чукур маънога эга бўлади.

Иккинчи босқич уламолар томонидан вара («эхтиёткорлик») деб тан олинади. Халол («рухсат этилган») ва харом («ман этилган»)ни ўта синчковлик билан фарқлаш бу босқичнинг энг характерли хусусиятидир.

3.Учинчи босқич вара (“эхтиёткорлик”)нинг давоми бўлиб, табиий равишда зухд («нафсни тийиш»)га олиб келади. Бунинг белгилари гунох, керагидан ортиқ нарсадан, худодан узоқлаштирувчи, хамма ўткинчи ишлардан тийилишдир. X асрга келиб зухд тушунчаси хатто хар қандай хохиш ва майл уйғотувчи барча фоний харакатни тарк этишгача бўлган нарсаларни ўз ичига ола бошлади.

4.Тўртинчи босқич - фақир(«қашшоқлик»)ликдир. Бу - ўзини ихтиёрий равишда мухтожликка махкум этиш, доимий тийилиш натижасида дунёвий ноз-неъматлардан воз кечишдир.

Бешинчи босқич зохидлик ва фақирликнинг хосиласи сифатида вужудга келади. Бу сабр бўлиб, сўфийга хос асосий хусусиятдир. Сабрнинг мохияти шундан иборатки, у қийин кечадиган барча нарсаларни итоаткорлик билан қабул қилишдан иборатдир. Е.Э.Бертельс Жунайд Боғдодийнинг қуйидаги фикрини келтиради: «сабр - аччиқ ва ёқимсиз нарсани норозиликни ифодаламасдан ютишдир».[1;64].

Олтинчи босқич - таваккул («худога ишониш»)дир. Унинг дастлабки даврида киши ўзини эртанги кун ташвишларидан соқит қилади, Унга айни дам билан қаноатланиш хос. Бундай одам худо бугун қандай ғамхўрлик қилган бўлса, эртага хам шундай бўлади деб умид қилади. Демак, сўфий хаётида бир лахза мухимдир, яъни ўтган нарса энди йўқ, келажак эса хали келмаган.

Еттинчи босқич ридо («итоат», «итоаткорлик») хисобланади. Бунда тақдирга ишониш асосий рол уй̆найди. Бу шундай холатки, унда киши тақдирнинг хар қандай зарбасига чидай олади ва хатто хафагарчилик хақида ўйламайди хам. Натижада унинг учун борлиқ ўз воқелигини йўқотади. [1;66].

Юқорида қайд қилинганларни Е.Э.Бертельс мақомлар деб атайди. Унингча мақомлар соликнинг тинимсиз харакатлари, бажарган машқлари асосида қўлга киритиладиган барқарор холатлардир. Олим хол мақомдан фарқли ўлароқ соликнинг харакатлари билан қўлга киритилмайди деган фикрни билдиради. Хол юқоридан юборилган, қандай тез келган бўлса, шундай ғойиб бўладиган илоқий бир мархаматдир. Е.Э.Бертельс тасаввуф назариётчилари томонидан кўрсатилган холнинг таснифини келтиради: 1) қурб («яқинлик»); 2) мухаббат («мухаббат»); 3) хавф («кўрқиш»); 4) ража (“умид”); 5) шавқ («эхтирос»); 6) унс («дўстлик»); 7) итмаънина («рухий хотиржамлик»); 8) мушохқада («мушохада қилиш, хаёлотга чўмиш»); 9) яқ̧ин («ишонч» - ишонч билан (дадил) харакат қилиш). [3;350].

Баъзан бу холатларга фано хам киритилади. Аммо аксарият тасаввуф назариётчилари фанони сўнгги манзил эмас деб хисоблайдилар. Фанодан кейин унинг мантиқий давоми сифатида бақо («абадият») келади. Боқийлик (абадий яшаш)ни тан олиш, солик эришиши мумкин бўлган холатларнинг энг олийсидир.

Тариқат охирги босқич бўлган хақиқатга етишиш билан тугайди. Шунинг учун дейди, Е.Э.Бертельс хақиқатга эришган солик, албатта, ички хис билан (интуитив 
равишда) худонинг бархақлигини теран англайди ва ўзининг унга алоқадорлигини идрок этади. Бунга асосланган сўфийлар ўзларини, кўпинча, ахл ал-хақиқат («хақиқий борлиқ кишилари») деб хисоблайдилар.

Сўфизмнинг дастлабки назариётчиларининг психологик тадқиқотлари гносеологик характердаги масалаларни кўтариб чиқишга олиб келди деб эътироф этади Е.Э.Бертельс. Бу олим мохиятан шариат, тариқат, хақиқат учлиги айни пайтда билишнинг уч босқичига хам мос келади деб хисоблайди. Бу босқичлар: 1) Илм алйақин («ишончли билим»). Бу шариат босқичида одатдаги мантиқий билишдир; 2) айн ал-йақин («тўлиқ ишонч»). Бу солик тариқат босқичида оладиган билимдир; 3) Хақхалйақин («хақиқий ишонч»). Бу билишнинг айнан хақиқат босқичига мос шаклидир. [2;107-108].

Демак, юқорида кўрсатилган унсурлар ўзига хос мавқега эга бўлиб, сўфийларнинг турмуш тарзида мухим ахамият касб этади.

\section{Адабиётлар:}

1.Бертельс Е.Э. Сўфизм ва тасаввуф адабиёти. Рус тилидан Ибодулла Мирзаев таржимаси. Т.“Ўзбекистон Миллий энциклопедияси". Давлат илмий нашриёти. 2005.

2.Мухаммадходжаев А. Гносеология суфизма. Душанбе. Дониш.1990.

3.Шайх Нажмиддин Кубро “усули ашара"дан.//Ислом тасаввуфи манбалари.(Тасаввуф назарияси ва тарихи). Илмий мажмуа. Тузувчи, сўзбоши ва изохлар муаллифи филология фанлари доктори, профессор Хамидулла Болтабоев. "Ўқитувчи" нашриёт-матбаа ижодий уйи. Тошкент-2005.

\section{БАДИИЙ ТАРЖИМАДА \\ МИЛЛИЙ-МАДАНИЙЛИКНИ АКС ЭТТИРИШ МАСАЛАЛАРИ}

\section{Йўлдошев Улуғбек Равшанбекович Фалсафба доктори, Ўзбекистон Давлат Жахон Тиллари Университети E-mail : yoldoshevu@mail.ru}

Бадиий таржимада миллий-маданийликни акс эттириш масалалари кўплаб изланувчиларнинг тадқиқот объекти сифатида ўрганилган бўлса хам, халигача бу мавзуда турли мунозаралар олиб борилмоқда. Баъзи тилшунослар, таржимашунослар аслиятдаги лексик бирликнинг маъносини таржима бериш кераклигини таъкидласа, яна бошқалари эса бундай лексик бирликларни таржима матнига тўғридан-тўғри олиб ўтиш зарур деб хисоблайдилар. Бу эса бадиий таржиманинг бу каби муаммолари хусусида қайта-қайта мурожаат этиш истагини билдиради.

Миллий-маданий ўзига хослик лексиканинг турли қатламларида ифодаланади. Бундай лексика инсон хаёти ва унинг барча ранг-барангликларини акс эттиради. Б.Исмоилованинг фикрига кўра, географик тушунчалар, маданий-тарихий терминлар, реалиялар номлари, миллат турмуш тарзи ва маданиятининг ўзига хослигини, қардошлик алоқалари, инсон кийимлари ва тана аъзолари номлари, ўсимлик ва ранг маъносини англатувчи сўзлар, кўп маънолилик хусусияти, коннотатив ва тасвирий ифода маъноларига эга сўзлар миллий-маданий ўзига хосликни англатувчи сўзлар хисобланади [5, 70]. Фикримизча, бу номлар гурухига расм-русумлар, анъана ва одатлар, диний қарашлар номларини хам киритиш мумкин. Одатда, бундай номлар жамият томонидан қабул қилинган хисобланади.

Сўзлар турли тилларда ўзларининг денотатив маъноларига кўра бир бирига мос тушади, лекин ифода маъноларига кўра фарқ қилиши мумкин. Сўзларнинг ифода маъноларидаги фарқ кўплаб омилларга, жумладан, маданий-этнографик хусусиятлар, турли мамлакат халқларининг ўзига хослиги, экологик шароитларнинг хар хиллиги, 
ижтимоий жихатдан жамият аъзоларининг турли қатламларга ажралиши кабиларга боғлиқ бўлади.

Лингвистик адабиётларда “миллий-маданий мохият", “миллий ўзига хослик”, “миллий маданиятнинг хусусиятлари”, “миллий-маданий ўзига хослик”, “миллий колорит”, “миллий-маданий семантика, этносемалар ва ижтимоий-маданий маъно”, “миллий ўзига хос маъно”, “миллий алоқадорлик семаси”, “худудий-маданий компонент ёки маданий компонент" терминлари қўлланади. Улар орасида семантикада миллий ўзига хосликни тўлиқ ифодалай оладиган тил бирлиги миллиймаданий ўзига хослик термини хисобланади.

Миллий-маданий ўзига хослик тушунчаси орқали семантик лексик бирликларнинг миллий ўзига хос воқелик, халқларнинг ижтимоий-тарихий ва иқтисодий ривожланиш хусусиятлари, миллий маданият, анъана ва маросимларнинг маълум бир хусусиятлари тушунилади. Миллий-маданий ўзига хослик тушунчаси қуйидагиларни ўз ичига олади: а) миллий-маданий маънога эга лексик қатлам, б) маданий компонентли маънога эга сўз, в) миллий-маданий коннотацияга эга сўз.

Миллий-маданий маъно термини денотатив-сигнификатив маъноли сўзларни билдиради ва мутлоқ миллий-маданий мохиятни ифодалайди. Масалан, ўзбек тилидаги "паранжи" сўзи миллий-маданий маъноли термин хисобланади. Бу терминлар гурухига муқобили йўқ сўзлар хам кириб, бундай сўзларнинг эквиваленти бошқа тилда мавжуд бўлмайди. Улар реалиялар, хос сўзлар деб хам аталади.

Маданий компонентли маънога эга сўзлар, одатда, эквивалент лексик бирликлар хисобланиб, ўзида миллий маданиятнинг ўзига хос маъносини ифодалайди ва бошқа тилдаги лексик бирликлар билан аталади. Масалан, ўзбек тилидаги “сандиқ" сўзининг эквивалентлари инглиз тилида “chest", “trunk” сўзларидир. Лекин, уларнинг вазифалари жихатдан бир биридан фарқи мавжуд. Масалан, сандиқнинг ўзбек тилидаги қўшимча вазифаси маданий компонент маънони ифодалайди. Сандиқ, одатда, уй-рўзғор жихози хисобланади. Лекин, қадимдан ўзбек халқи сандиқни уйнинг мехробига жойлаштиради ва устига кўрпа-тўшаклар йиғиб қўяди. Бундан ташқари, ўзбек халқи расм-русумларига кўра, келиннинг ота-онаси келин куёв хонадонига кетаётган пайтда бериладиган “келин сепи” деб аталган турли уй-рўзғор анжомлари, кўрпа-тўшаклар қаторида сандиқ хам бўлади. Сандиқнинг мана шу қўшимча маънолари унинг маданий компонент маънолари хисобланади.

Миллий-маданий коннотацияга эга сўзлар асосан, стилистик воситалар билан боғлиқ коннотатив маънолар хисобланади. Бунда, стилистик воситалар ёрдамида яратилган тасвирий ифода бирликларининг баъзи коннотатив маънолари бошқа тилда учрамаслик холатлари билан боғлиқ. Масалан, инглиз тилида "as light as a feather" (патдек енгил) иборасининг ўзбек тилидаги муқобили “қушдек енгил” ибораси хисобланади.

Мазкур рисоламизда бадиий таржимада миллий-маданийликни акс эттириш масаласини инглиз тилига таржима қилинган ўзбек халқ латифалари мисолида кўриб чиқамиз. Айнан маданий бўёқдорликка эга бўлган лексик бирликлар ёрдамида кулги яратилган латифалар ўзига хос ахамиятга эга ва уларни таржима қилишда таржимон қийинчиликларга дуч келиши табиий.

Ўзбек халқ латифаларида хам миллий-маданий лексик бирликлар ёрдамида яратилган бир неча латифалар борки, улар тадқиқ этиш учун ахамиятлидир. Жумладан, “Салла ва савод” латифасида хам шу каби холатни учратиш мумкин.

Мазкур латифада ўзбек миллий кийими хисобланган салла миллий-маданий лексик бирлик воситасида кулги эффекти яратилмоқда. Ўзбек халқи анъанавий миллий кийимлари сирасига дўппи, яктак, белбоғ, иштон, чориқ, телпак, салла, чопон, махси-ковушлар киради. Ушбу кийимларнинг хар бири ўзининг маросимий маъносига эга. 
Салла I (а. - сават, тўрхалта; тугун) - узунлиги 1,5 метрдан 7 метргача бўладиган, дўппи, қулоқ, телпак устидан ўраладиган сидирға мато, дока; мусулмон эркакларининг бош кийими. II. Маърака-маросимларда тухумга қорилган хамирдан салла шаклида ўраб, ёғда пишириладиган миллий пишириқ; ўрама $[8,428]$. Демак, салла сўзининг иккинчи маъносида ўзига хос миллий маъно мавжудлиги кўриниб турибди. Ушбу сўзнинг биринчи маъноси, яъни кийим турини англатиб келганда хам, назаримизда миллий маъно мавжуд. Фикримизча, салла сўзининг Ўрта Осиёга кириб килиши ислом динининг бу ерга ёйилиши билан боғлиқ. Ўрта асрларда туркий халқлар орасида олиму-уламолар, дин пешволари, ўқимишли инсонлар салла кийиб юришган. Хозирги кунда эса салла бош кийимидан асосан, имом хатиблар фойдаланишади. Демак, салла диний уламоларни оддий инсонлардан ажралиб туришида хам мухим рол уйнайди. Фаразимизча, қадимдан арабларда, Ўрта асрларда мусулмон туркий ва бошқа халқларда салла кенг кўламда фойдаланиб, унинг бош ва қулоқни иссиқ-совуқдан асраш вазифасидан ташқари яна бир вазифаси хам бўлган. Бу халқлар савдо ёки бошқа юмуш билан узоқ юртларга сафар қилган вақтларда бирор савдогар йўлда қазо қилиб қоладиган бўлса, унинг салласи кафан вазифасини хам бажарган бўлиши мумкин. Салланинг иккинчи маросимий таом маъноси унинг биринчи - кийим маъносидан метафорик маънода олинган.

“Салла ва савод” латифа инглиз тилига М.Петерсон томонидан таржима қилинган. Латифа сарлавхаси “The Intelligent Turban” тарзида ўгирилган. М.Петерсон мазкур латифадаги “салла"миллий-маданий лексик бирлигини инглиз тилидаги эквиваленти “turban” сўзи билан алмаштирган. Бу борада М.Петерсоннинг фикрига қўшиламиз, чунки OALD луғатда ушбу сўзнинг қуйидаги изохини учратдик: a long piece of cloth wound tightly around the head, worn, for example, by Muslims or Sikh men [1, 1649]. Бу айнан ўзбек халқи орасида кенг тарқалган ва хозирда хам истемолда бўлган "салла" сўзини англатади.

“Салла” миллий-маданий лексик бирлиги “Салла - чопоннинг эгаси” [6, 192]. латифасида хам қўлланган. Мазкур латифанинг таржимасида хам М.Петерсон “салла” сўзини тўғри таржима қила олган. Инглиз тилига ўгирилган "The Owner of a Turban and a Robe" [3, 76]. латифасида “салла" сўзининг эквиваленти қилиб "turban" сўзи танланган. Мазкур латифада бундан ташқари ўзбек халқининг миллий кийими “чопон” сўзи хам қўлланган бўлиб, таржимон ушбу сўзни “robe” деб таржима қилган. Ушбу сўзнинг инглиз тили изохли луғатларида қуйидаги маъноларини учратиш мумкин: 1. A long, loose outer piece of clothing, especially one worn as a sign of rank or office at a special ceremony (узун, кенг кийим устидан кийиладиган кийим бўлиб, махсус маросимда унвон ёки мансаб белгиси сифатида кийилади) $[1,1316]$. 2. A long loose piece of clothing, worn by an importarnt person such as a priest during an official ceremony (узун кенг кийим бўлиб, расмий маросим давомида диний амалларни амалга оширадиган шахс томонидан кийилади) [2, 1290]. Демак, robe (мантия, ридо) асосан расмий маросимларда диний амалларни амалга оширадиган шахс томонидан кийилади.

Ўзбек халқ латифаларидан қўлланган “тўн”, “чопон” миллий-маданий лексик бирликлари эса халқимиз орасида махсус маросимлардан ташқари хар кунги хаётимизда хам кенг фойдаланилади. Юқорида таъкидлаб ўтганимиздек, “тўн” сўзи “чопон” сўзининг синоними хисобланади. Буни ЎТИЛда хам кўриш мумкин: тўн - олди очиқ, пахтали ёки пахтасиз узун устки миллий кийим; чопон $[8,238]$. ўнсўзи ўзбек халқ миллий кийимларидан бири хисобланади. Анъанавий кийим-кечаклар этноснинг ўзига хос этноижтимоий рамзи ёки хар бир халқнинг этник мансублигини, ижтимоий ва оилавий холатини кўрсатувчи ўзига хос “этник паспорт” бўлган [2, 299]. Дархақиқат, одамни кийимсиз кўз олдимизда гавдалантириб бўлмаганидек, хар бир этносни хам анъанавий миллий либосларисиз тасаввур қилиш мушкул. Бир сўз билан айтганда, миллий кийимлар халқнинг ўзига хос этно-таърифий тимсоли хисобланади. 
Шу боисдан хам хар бир халқ ўз хўжалик йўналиши, турмуш тарзи, яшаётган минтақасидаги иқлим, ижтимоий тузум, мафкуранинг баъзи унсурлари, урф-одатлар, диний эътиқод меъёрларига мос тарзда кийинган. Қолаверса, кийим тараққиёти билан хамоханг тарзда ўзига хос кийиниш маданияти хам ривожланиб боради. О.А. Сухарева хақли равишда таъкидлаганидек, кийимларнинг турли-туман янги кўринишлари яратилишига кишилар турмуш тарзи, мехнат фаолияти ва иқлим таъсири билан бирга ўша жамият маданий тараққиёти ва эстетик диди хам сезиларли таъсир этган [7, 299].

Ўзбек халқининг хам ижтимоий келиб чиқиши, иқлими, турмуш тарзи нуқтаи назардан бир қатор миллий кийимлари мавжуд бўлиб, улар регионал жихатдан сезиларли даражада фарқ қилади. Масалан, А.Ашировнинг таъкидлашича, Фарғона водийси ўзбеклари ёзда анъанавий миллий кийим-бош тарзида - дўппи, яктак, белбоғ, иштон, чориқ, қишда эса - телпак, чопон, белбоғ, шим, махси-ковуш кийиб юришган [4, 183]. Бундан хулоса қилиб, “тўн” сўзини ўзбек тили миллий-маданий лексик бирлиги таркибига киритишимиз мумкин.

Ўзбек халқ латифаларида “тўн”, “чопон”сўзлари қўлланган бир нечта латифаларни учратишимиз мумкин. Жумладан, “Барибир келади” [6, 177]. латифасида қуйидаги жумлада “чопон” сўзи қўлланган: Бир куни Афандининг чопонини ўгри олиб кочди, Афанди ўғрининг орқасидан кувлаб ўтирмасдан, тўғри қабристонга бориб, бир очиқ гўр устида ўтирди. Ушбу латифада қўлланган “чопон” сўзини М.Петерсон инглиз тилига “robe" тарзида таржима қилган: Once a robber stole Afandi's robe. Afandi didn't run after him, instead he went to the cemetery and sat by a freshly dug grave. (He will Come Here) $[3,79]$. Бундан ташқари “Подшонинг инъоми” $[6,206]$. латифасида хам “чопон” сўзининг синоними “тўн” сўзи билан боғлиқ кулги холат акс этган:Подшо бир маросимда атокли одамларга тўн кийгизди ва Афандини масхара құлиш учун унга эшакнинг тўқимини берди. Таржимон “тўн” сўзини хам инглиз тилига "robe” тарзида ўгирган: Once, at a feast, the king decided to present all the outstanding people with the gift of a new robe, but in order to tease Afandi, he presented him with a donkey's blanket. (A Present from the King) [3, 87].

Демак бадиий таржимада, хусусан, латифалар таржимасида халқларнинг миллий маданияти, урф-одатлари, турмуш тарзи, ўзига хос анъаналарини тўғри талқин қилган холда хорижий тилларга таржима қилиш аслиятдаги кулгини таржима матнига хам олиб ўтишда катта ахамиятга эга. Бу жихат латифаларни таржима қилишда адекват таржимага эришишга ва ўқувчининг аслият матнидаги кулгини тўлақонли хис этишига ёрдам беради.

\section{Адабиётлар :}

1. Hornby A.S. "Oxford Advanced Learner's Dictionary". - Oxford: Oxford University Press, P.1649.

2. Macmillan For Advanced Learners. Printed and bound in Malaysia, in 2010.- P.1290.

3. Peterson Marilyn. Treasury of uzbek legends and lore. - T.: Qatortol - Kamolot, 2000.- P.76. 4. Аширов А. Ўзбек халқининг қадимий эътиқод ва маросимлари. - Т.: А.Навоий номидаги Ўзбекистон Миллий кутубхонаси нашриёти, 2007. 183-б.

5. Исмаилова Б. Категория образности и средства ее выражения в словообразовательной системе английского и киргизского языков: Дисс. ... канд. филол. наук. - Т., 1989. - С. 70.

6. Саримсоқов Б, Йўлдошева Ф. Афанди латифалари. -Т.: Адабиёт ва санъат нашриёти, 1990. - Б.192.

7. Сухарева О.А. Древние черты в головных уборах народов Средней Азии. Среднеазиатский этнографический сборник. - М., 1954.-С. 299.

8. Ўзбек тилининг изохли луғати. 3-жилд. - Т.: Ўзбекистон миллий энциклопедияси, 2007. - Б.428. 